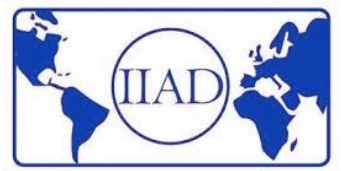

\title{
Age-related digestive alterations and their impact on nutrients digestibility
}

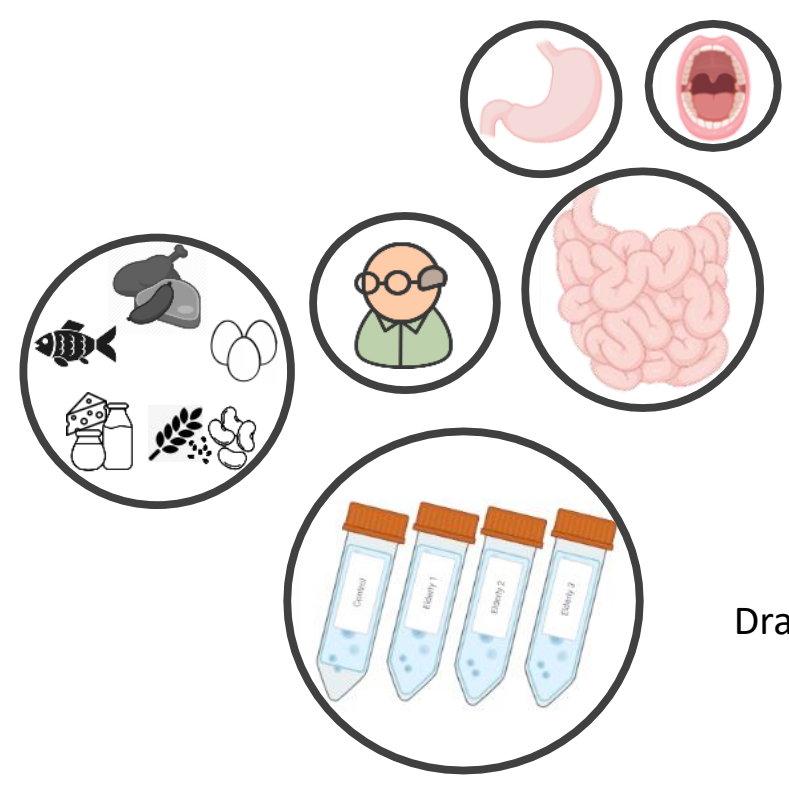

\section{DOCTORAL THESIS}

Presented by:

Ever Hernández Olivas

Supervised by:

Dra. Ana Ma Andrés Grau

Dra. Ana Belén Heredia Gutiérrez 


\section{UNIVERSITAT POLITÈCNICA DE VALÈNCIA}

\section{INSTITUTO UNIVERSITARIO DE INGENIERIA DE ALIMENTOS PARA EL DESARROLLO}

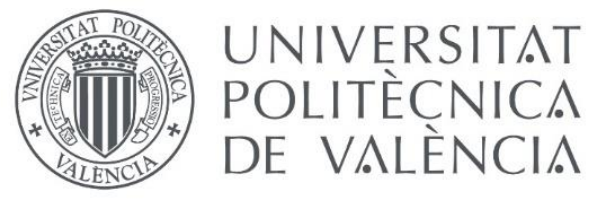

Age-related digestive alterations and their impact on nutrients digestibility

DOCTORAL THESIS

Presented by: Ever Hernández Olivas

Supervisors:

Dra. Ana Ma Andrés Grau Dra. Ana Belén Heredia Gutiérrez 


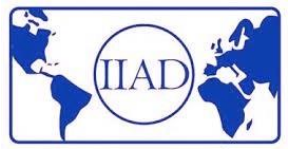

Dra. Ana Ma Andrés Grau, Catedrática de Universidad perteneciente al Departamento de Tecnología de Alimentos de la Universidad Politécnica de València,

Dra. Ana Belén Heredia Gutiérrez, profesora titular del Departamento de Tecnología de Alimentos de la Universitat Politècnica de València,

CONSIDERAN: que la memoria titulada "Age-related digestive alterations and their impact on nutrients digestibility" que presenta D. Ever Hernández Olivas, para aspirar al grado de Doctor de la Universitat Politècnica de València, y que ha sido realizada bajo su dirección en el Instituto Universitario de Ingeniería de Alimentos para el Desarrollo de la Universitat Politècnica de València, reúne las condiciones adecuadas para constituir su tesis doctoral, por lo que AUTORIZAN a el interesado para su presentación.

Valencia, Junio de 2021 



\section{Agradecimientos}

\section{A todas las personas que formaron parte de este camino...}

A Cynthia, mi esposita, mi familia, por tomarnos de la mano con mucho amor en esta aventura. Espero que sigamos recorriendo muchos más caminos juntos. ¡Lo volvimos hacer y lo repetiría mil veces más!

A mis padres, hermanos y sobrinos, por ese amor y apoyo incondicional aun a la distancia.

A mis suegros y cuñados, pues en cada llamada de fin de semana demostraban empujones de motivación y gozo de los logros obtenidos.

A mis compañeros del laboratorio e instituto, pues cada momento de arduo trabajo, estrés y preocupaciones me dejaron mucho aprendizaje. Las tardes de café y conversación le dieron su toque divertido. Me llevo lo mejor de cada uno de ustedes.

A mis amigos los doctores, discípulos de Beto, pues en ellos encontré guía y motivación en este mundo de la investigación.

Al Consejo Nacional de Ciencia y Tecnología (CONACyT, México), porque gracias a esa beca el sueño pudo materializarse.

A mis directoras, Ana Andrés y Ana Heredia. Por toda esa paciencia, apoyo, libertad y confianza dada. El conocimiento y formación adquirida me los Ilevo con orgullo, será mi herramienta de trabajo más valiosa. Ese viaje trasatlántico valió mucho la pena. 


\section{Abstract}

Population aging is a phenomenon unparalleled in human history. It is expected that people over 65 years, or the elderly, will double the child population for the first time by 2050 . Turning 65 implies a series of physiological changes that include, among others, a loss of functionality of the organs involved in the digestive process. In this sense, the study of the digestibility of nutrients, mainly proteins, and the bioaccessibility of certain vitamins and minerals of interest for the health of the senior population, are of special interest. Only on the basis of scientific evidence will it be useful to establish nutritional recommendations at the clinical level, and to design functional foods oriented to the specific needs of this population group. Among the nutrients most affected by the common digestive disorders of the elderly, proteins represent the most important challenge. It is known that oral, gastric and intestinal disorders affect their digestion and absorption, contributing to the decline of general health status, resulting in a loss of muscle mass, increase and change of lipid mass distribution, weaker bones and joints, some metabolic and cardiovascular diseases, among other psychological and social changes.

The main objective of this doctoral thesis has been to assess the impact of the different alterations appearing with age at oral, gastric and intestinal level on the digestibility of proteins, fats and carbohydrates, as well as on the bioaccessibility of micronutrients of interest, in protein-rich foods whose consumption is recommended for people over 65 years of age, and which differ from each other in the origin of this macronutrient (fish, dairy products, eggs, meat, legumes and cereals). To achieve this objective, in vitro static digestion models were used to simulate, under controlled laboratory conditions, the digestive process of different population groups and to sample in a non-invasive way.

The most relevant results of this doctoral thesis are presented in five chapters, addressing in each food group, the digestive response derived 
both from physiological alterations in the senior population, as well as from certain factors inherent to the food.

Regarding the digestive alterations associated with age, it is possible to affirm that pancreatic and biliary insufficiencies were the main responsible for the significant reduction in the proteolysis extent in almost all the studied foods. The results indicate a higher protein digestibility in lean fish, hard-boiled and poached eggs, cheeses, chicken and beef meats, as well as legumes in general. Fat digestibility, on the other hand, was not compromised. Moreover, cheeses, sardines, as well as some legume and cereal grains would contribute to a greater supply of bioaccessible calcium than other food matrices. For fat-soluble vitamins, the intake of salmon and cheeses resulted as excellent sources of both vitamin A and D3 in their bioabsorbable form, while the bioaccessibility of both vitamins in eggs depended on the cooking method. In addition, pork provided the greatest antihypertensive effect, while turkey meat exerted the greatest effect as antioxidant. Finally, the essential/non-essential amino acid ratio increased under altered conditions at the end of digestion, compared to standard healthy adult conditions. Thus, even with impaired protein digestibility, digests will have an effect against sarcopenia. 


\section{Resumen}

El envejecimiento poblacional es un fenómeno sin parangón en la historia de la humanidad. Así, se espera que las personas mayores de 65 años, o población sénior, doblen por primera a la población infantil en 2050. Cumplir años implica una serie de cambios a nivel fisiológico que comprenden, entre otros, una pérdida de funcionalidad de los órganos implicados en el proceso digestivo. En este sentido, el estudio de la digestibilidad de nutrientes, principalmente proteínas, y la bioaccesibilidad de determinadas vitaminas y minerales de interés para la salud de la población sénior, son de especial interés. Solo a partir de evidencias científicas será posible establecer recomendaciones nutricionales de ámbito clínico, y diseñar alimentos funcionales orientados a las necesidades específicas de este grupo poblacional. Entre los nutrientes mayoritariamente afectados por las alteraciones digestivas típicas de personas sénior, las proteínas suponen el reto más importante. Se sabe que las alteraciones orales, gástricas e intestinales afectan su digestión y absorción, contribuyendo al declive del estado general de salud, dando lugar a una pérdida de masa muscular, incremento y cambio de distribución de masa lipídica, huesos y articulaciones más débiles, algunas enfermedades metabólicas y cardiovasculares, entre otros cambios de tipo psicológico y social.

El objetivo principal de esta tesis doctoral ha sido evaluar el impacto de las diferentes alteraciones que aparecen con la edad a nivel oral, gástrico e intestinal en la digestibilidad de proteínas, grasas y carbohidratos, así como en la bioaccesibilidad de micronutrientes de interés. Concretamente, se han analizado en alimentos ricos en proteína cuyo consumo está recomendado para mayores de 65 años, y que difieren entre sí en el origen de la proteína (pescados, lácteos, huevo, carne, legumbres y cereales). Para alcanzar este objetivo, se recurrió a modelos digestión in vitro en estático los cuales permiten simular, en condiciones controladas de laboratorio, el 
proceso digestivo de diferentes grupos de población y muestrear de forma no invasiva.

Los resultados más relevantes de esta tesis doctoral se presentan en cinco capítulos, abordando en cada grupo alimenticio, la respuesta digestiva derivada tanto de las alteraciones fisiológicas dados en población sénior, como de ciertos factores inherentes al alimento.

En cuanto a las alteraciones digestivas propias de la edad, es posible afirmar que las insuficiencias pancreática y biliar fueron las principales encargadas de reducir de forma significativa la extensión de la proteólisis en casi la totalidad de alimentos estudiados. Los resultados indican una mayor digestibilidad proteica en pescados magros, el huevo duro y escalfado, quesos, carnes de pollo y de vacuno, así como legumbres en general. La digestibilidad de las grasas, en cambio, no resultó negativamente afectada. Por otro lado, los quesos, sardina, así como algunos granos de legumbres y cereales contribuirían satisfactoriamente al aporte de calcio bioaccesible en mayor medida que otras matrices alimentarias. En cuanto a las vitaminas liposolubles, la ingesta de salmón y de quesos fueron una excelente fuente tanto de vitamina A como D3 en su forma bioabsorbible; mientras que la bioaccesibilidad de ambas vitaminas en huevo, dependió del método de cocinado. Además, la carne de cerdo brinda el mayor efecto antihipertensivo, mientras que la de pavo ejerce mayor efecto como antioxidante. Por último, la relación aminoácidos esenciales/ no esenciales aumentó en condiciones alteradas al final de la digestión, en comparación con las condiciones estándar de adulto sano. Por lo que, aun con una digestibilidad de proteínas afectada, los digeridos tendrán efecto contra la sarcopenia. 


\section{Resum}

L'envelliment poblacional és un fenomen sense parangó en la història de la humanitat. Així, s'espera que les persones majors de 65 anys, o població sènior, dobleguen per primera a la població infantil en 2050. Complir anys implica una sèrie de canvis a nivell fisiològic que comprenen, entre altres, una pèrdua de funcionalitat dels òrgans implicats en el procés digestiu. En aquest sentit, l'estudi de la digestibilitat de nutrients, principalment proteïnes, i la bioaccesibilitat de determinades vitamines i minerals d'interès per a la salut de la població sènior, són d'especial interès. Només a partir d'evidències científiques serà útil establir recomanacions nutricionals d'àmbit clínic, i dissenyar aliments funcionals orientats a les necessitats específiques d'aquest grup poblacional. Entre els nutrients majoritàriament afectats per les alteracions digestives típiques de persones sènior, les proteïnes suposen el repte mes important. Se sap que les alteracions orals, gàstriques i intestinals afecten la seua digestió i absorció, contribuint al declivi de l'estat general de salut, donant lloc a una perduda de massa muscular, increment i canvi de distribució de massa lipídica, ossos i articulacions més febles, algunes malalties metabòliques i cardiovasculars, entre altres canvis de tipus psicològic i social.

L'objectiu principal d'aquesta tesi doctoral ha sigut avaluar l'impacte de les diferents alteracions que apareixen amb l'edat a nivell oral, gàstric $i$ intestinal en la digestibilitat de proteïnes, greixos i carbohidrats, així com en la bioccesbilitat de micronutrients d'interès, en aliments rics en proteïna el consum de la qual està recomanat per a majors de 65 anys, i que difereixen entre si en l'origen d'aquest macronutrient (peixos, lactis, ou, carn, llegums i cereals). Per a aconseguir aquest objectiu, es va recórrer a models digestió in vitro en estàtic els quals permeten simular, en condicions controlades de laboratori, el procés digestiu de diferents grups de població i mostrejar de forma no invasiva. 
Els resultats més rellevants d'aquesta tesi doctoral es presenten en cinc capítols, abordant en cada grup alimentós, la resposta digestiva derivada tant de les alteracions fisiològiques donats en població sènior, com d'uns certs factors inherents a l'aliment.

Quant a les alteracions digestives pròpies de l'edat, és possible afirmar que les insuficiències pancreàtica i biliar van ser les principals encarregades de reduir de manera significativa l'extensió de la proteòlisien quasi la totalitat d'aliments estudiats. Els resultats indiquen una major digestibilitat proteica en peixos magres, l'ou dur i escalfat, formatges, carns de pollastre i de boví, així com llegums en general. La digestibilitat dels greixos, en canvi, no va resultar negativament afectada. D'altra banda, els formatges, sardina, així com alguns grans de llegums i cereals contribuirien satisfactòriament a l'aportació de calci bioaccesible en major mesura que altres matrius alimentàries. Quant a les vitamines liposolubles, la ingesta de salmó i de formatges van ser una excel-lent font tant de vitamina A com D3 en la seua forma bioabsorbible; mentre que la bioaccesibilitat de totes dues vitamines en ou, va dependre del mètode de cuinat. A més, la carn de porc brinda el major efecte antihipertensiu, mentre que la de polit exerceix major efecte com a antioxidant. Finalment, la relació aminoàcids essencials/ no essencials va augmentar en condicions alterades al final de la digestió, en comparació amb les condicions estàndard d'adult sa. Pel que, fins i tot amb una digestibilitat de proteïnes afectada, els digerits tindran efecte contra la sarcopènia. 


\section{TABLE OF CONTENTS}

Justification of the study................................................................... 1

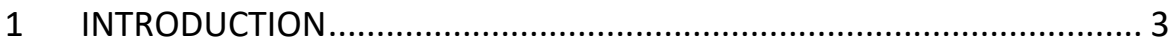

$1.1 \quad$ Food digestion ......................................................................... 4

1.1.1 Digestion process........................................................... 4

1.1.1.1 Oral stage ............................................................... 4

1.1.1.2 Gastric stage ........................................................... 6

1.1.1.3 Small Intestinal stage ................................................. 9

1.1.1.4 Large Intestinal stage ............................................. 11

1.1.2 Nutrients: Digestion and absorption ............................. 13

1.1.2.1 Proteins ....................................................................... 13

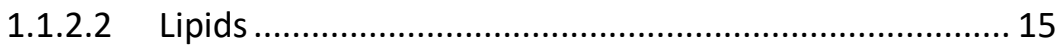

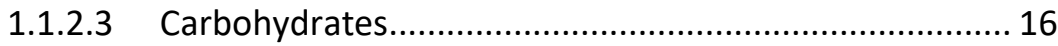

1.1.2.4 Micronutrients and bioactive compounds .................. 17

1.1.3 Factors affecting food digestion ..................................... 18

1.1.3.1 Food-related factors .................................................. 19

1.1.3.2 Host-related factors ................................................ 21

1.2 Gastrointestinal alterations in elders and their impact on digestibility and bioaccessibility of nutrients ..................................... 23

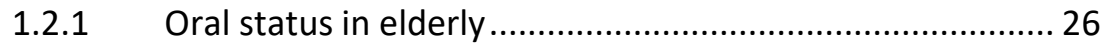

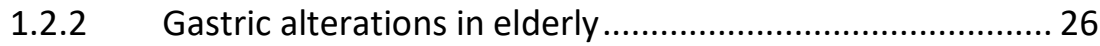

1.2.3 Small intestine changes in elderly .................................. 27

1.2.4 Colonic changes in elderly ........................................... 27

1.3 In vitro digestion model for elderly ........................................ 28

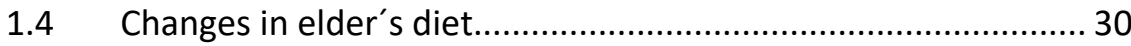




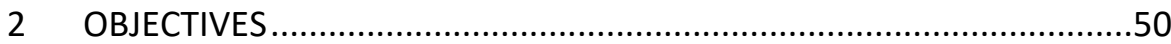

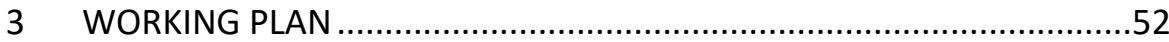

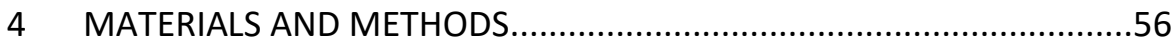

4.1 Sample preparation for digestion studies ……………………....57

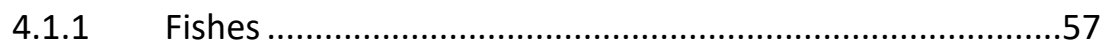

4.1.2 Milk and dairy products..................................................57

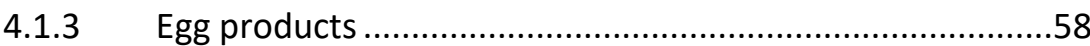

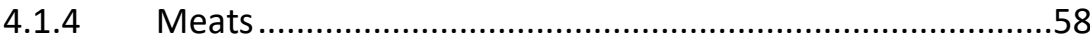

4.1.5 Cereals and legumes..........................................................58

4.2 Physico-chemical characterization of food products prior to

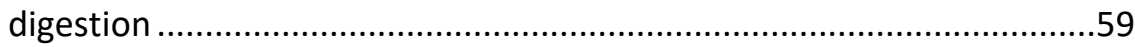

4.2.1 Proximal composition analysis ......................................59

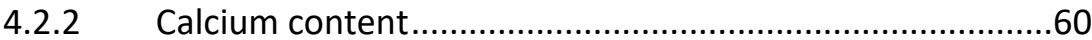

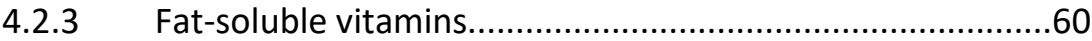

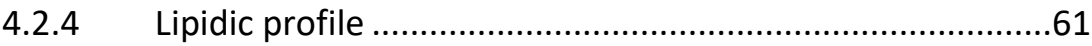

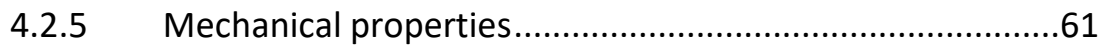

4.3 Simulation of in vitro gastrointestinal digestion in elderly .........61

4.4 Analytical determinations in digesta ...........................................65

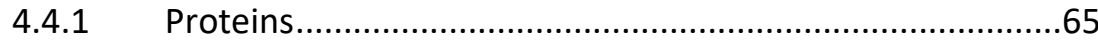

4.4.1.1 Free amino acids (GC-MS) ............................................65

4.4.1.2 Trichloroacetic acid (TCA) soluble protein .......................65

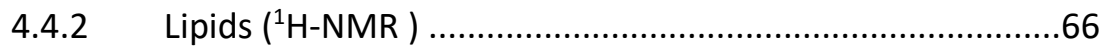

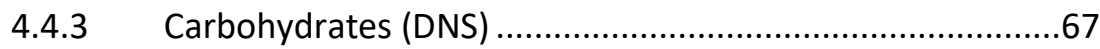

4.4.4 Micronutrients and bioactive compounds ..........................68

4.4.4.1 Fat-soluble vitamins (HPLC) ...........................................68 


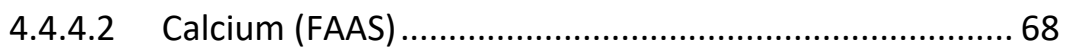

4.4.4.3 Functional properties of end-digestion products from meats 68

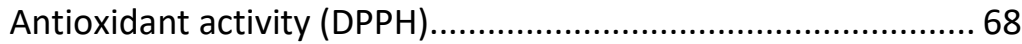

Angiotensin Converting Enzyme inhibitory activity (ACE ia (\%)) 69

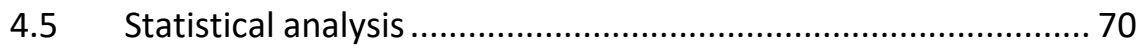

4.5.1 Multifactorial analysis of variance (ANOVA).................... 70

4.5.2 Principal Components Analysis (PCA) and Pearson

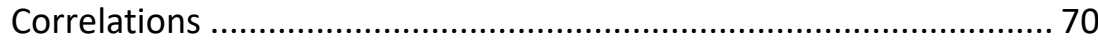

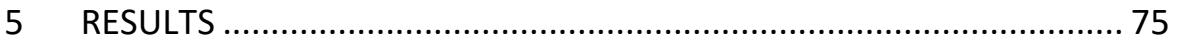

5.1 Chapter 1: Impact of elderly gastrointestinal alterations on in vitro digestion of salmon, sardine, sea bass and hake: Proteolysis, lipolysis and bioaccessibility of calcium and vitamins............................................ 76

5.2 Chapter 2: Understanding the role of food matrix on the digestibility of dairy products under elderly gastrointestinal conditions. 111

5.3 Chapter 3: Impact of cooking preparation on in vitro digestion of eggs simulating some gastrointestinal alterations in elders. 149

5.4 Chapter 4: Impact of common gastrointestinal disorders in elderly on in vitro meat protein digestibility and related properties.

5.5 Chapter 5: Age-related gastrointestinal alterations of legumes and cereal grains digestibility. 231

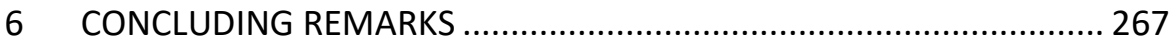

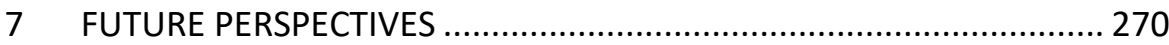




\section{LIST OF TABLES}

Table 1.2.1. Social, psychological and physiological issues responsible of malnutrition in elders (Source: Rémond et al. (2015)) ${ }^{3}$ 24

Table 1.3.1. Summary of the oral, gastric and intestinal conditions to perform an in vitro digestion simulation with the healthy standard conditions established by the INFOGEST group 7,85 29

Table 1.3.2. Summary of the oral, gastric and intestinal conditions to perform an in vitro digestion simulation with the elderly conditions suggested by the INFOGEST group ${ }^{14}$ 30

Table 1.4.1. Rich-protein foods selected to be digested according to the selection performed by Spanish elders throughout a questionnaire. 34

Table 1.4.1. In vitro methodology of dietary and host-related factors affecting digestion of protein-rich foods under elderly gastrointestinal disorders 55

Table 4.3.1. Specific oral, gastric and intestinal conditions of the four in vitro digestion models established in this study: control (C) and elderly (E1, E2 and E3) GI conditions.

Table 5.1.1. Specific gastrointestinal conditions of the four in vitro digestion models of this study: control and eldely GI conditions 85

Table 5.1.2. Total contents of moisture, protein, fat, ashes, calcium and vitamins A and D3 in the four types of microwaved cooked fish (salmon, sea bass, sardine and hake). 
Table 5.1.3. Amino acids profile ( $\mathrm{mg}$ free amino acid / $100 \mathrm{~g}$ fish protein) of hake and sea bass achieved under different GI conditions (control (C), Elderly 1 (E1), Elderly 2 (E2), Elderly 3 (E3) models)............................. 96 Data shown are mean values from triplicates and the standard deviation. ${ }^{\text {abc }}$ Different lowercase letters indicate significant differences between models, with a significance level of $95 \%(p<0.05)$.Table 5.1.4. Amino acids profile (mg free amino acid / $100 \mathrm{~g}$ fish protein) and proteolysis extent of salmon and sardine achieved under different GI conditions (control (C), Elderly 1 (E1), Elderly 2 (E2), Elderly 3 (E3) models). 96

Table 5.1.5. Molar percentages of acyl groups (AG) supported on the different glyceryl backbone structures (TG, 1,2-DG, 1,3-DG, 2-MG, 1-MG) and fatty acids (FA), present in the lipidic phase of sea bass and salmon nondigested (ND) and digested samples under different GI conditions (control (C), Elderly 1 (E1), Elderly 2 (E2), Elderly 3 (E3) models). 98

Table 5.1.6. Micronutrients (Calcium and vitamins A and D3) bioaccessibility in sea bass, salmon, sardine and hake under different GI conditions (control (C), Elderly 1 (E1), Elderly 2 (E2), Elderly 3 (E3) models). 101

Table 5.2.1. Macro and micronutrients contents in dairy products (milk, yogurt, fresh cheese and aged cheese) expressed per g of product....... 124 Table 5.2.2. Amino acids profile ( $\mathrm{mg}$ free amino acid/g protein) of milk and yogurt digested under control (C) and Elderly (E1, E2 and E3) GI conditions and reduction (\%) of amino acid released with respect to the control.... 131 Table 5.2.3. Amino acids profile ( $\mathrm{mg}$ free amino acid / g product) of fresh and aged cheese digested under different in vitro digestion models (C: 
control; E1: Elderly 1; E2: Elderly 2; E3: Elderly 3) and reduction (\%) of amino acid released with respect to the control. .132

Table 5.2.4. Molar percentages of acyl groups (AG) supported on the different glyceryl backbone structures (TG, 1,2-DG, 1,3-DG, 2-MG, 1-MG) and free fatty acids (FFA), present in the non-digested (ND) and in vitro digested samples (C: Control; E1: Elderly 1; E2: Elderly 2; E3: Elderly 3) of fresh and aged cheese.

Table 5.3.1. Total Contents (per $100 \mathrm{~g}$ Dry Basis) of Water, Protein, Fat, Ashes, Carbohydrates, Vitamin A and Vitamin D3 of Hard-boiled, Poached and Omelet Eggs $\mathrm{e}$ 162

Table 5.3.2. Amino Acids Profile (g/100 g Initial Protein) Resulting from In Vitro Digestion of Hard-boiled Egg under Different Simulated GI Conditions (Control (C), Elderly 1 (E1), Elderly 2 (E2), Elderly 3 (E3) Models) ${ }^{d}$ 164

Table 5.3.3. Amino Acids Profile (g/100 g Initial Protein) Resulting from In Vitro Digestion of Poached Egg under Different Simulated GI Conditions (Control (C), Elderly 1 (E1), Elderly 2 (E2), Elderly 3 (E3) Models) ${ }^{d}$ 165

Table 5.3.4. Amino Acids Profile (g / $100 \mathrm{~g}$ Initial Protein) Resulting from In Vitro Digestion of Omelet Egg under Different Simulated GI Conditions (Control (C), Elderly 1 (E1), Elderly 2 (E2), Elderly 3 (E3) Models) d .........166

Table 5.3.5. Molar Percentages of Acyl Groups (AG) Supported on the Different Glyceryl Backbone Structures (TG, 1,2-DG, 1,3-DG, 2-MG, 1-MG) and Free Fatty Acids (FFA) and Cholesterol Content (mg/g Fat), Present in Non-digested (ND) and Digested Hard-boiled, Poached and Omelet Eggs. In 
Vitro GI Models: Control (C), Elderly 1 (E1), Elderly 2 (E2), Elderly 3 (E3) e 174

Table 5.4.1. GI parameters established at oral, gastric and intestinal stages for the control (C) and elderly models (E1, E2 and E3). 198

Table 5.4.2. Proximal composition (g/100 g of wet basis) and mechanical parameters of microwave-cooked chicken, turkey, pork and beef entrecote obtained from Textural Profile Analysis (TPA) 204

Table 5.4.3. Amino acids profile (g/100 g protein) of intestinal digesta of chicken obtained under in vitro simulation of control (C) and elderly GI conditions (E1, E2 and E3).

Table 5.4.4. Amino acids profile (g/100 g protein) of intestinal digesta of turkey obtained under in vitro simulation of control (C) and elderly GI conditions (E1, E2 and E3). 213

Table 5.4.5. Amino acids profile (g/100 g protein) of intestinal digesta of pork obtained under in vitro simulation of control (C) and elderly GI conditions (E1, E2 and E3). 214

Table 5.4.6. Amino acids profile (g/100 g protein) of intestinal digesta of beef obtained under in vitro simulation of control (C) and elderly GI conditions (E1, E2 and E3). 215

Table 5.5.1. Specific GI conditions set for the 4 in vitro digestion models of this study. 239

Table 5.5.2. Total contents of water, crude protein, fat, ash, reducing sugars, fiber, starch and calcium in cooked legumes (chickpea, lentils, soya bean and white bean) and grains (whole oats, whole spelt and quinoa). 244 
Table 5.5.3. EAA profile (mg FAA/g protein) of chickpea, lentils, soya bean, white bean, oats, spelt and quinoa after in vitro digestion using different elderly digestion models. 249

Table 5.5.4. NEAA profile (mg FAA/g protein) of oats, spelt, quinoa, chickpea, lentils, soya bean and white bean after in vitro digestion using different elderly digestion models. 250 


\section{LIST OF FIGURES}

Figure 1.1.1. Diagram of the mechanical, chemical and enzymatic actions taking place in the mouth.

6

Figure 1.1.2. Overview of the mechanical, chemical and enzymatic mechanisms given in the stomach.......................................................... 8

Figure 1.1.3. Overview of the mechanical, chemical and enzymatic mechanisms given in the small intestine.

Figure 1.1.4. Overview of the mechanical action and microbial process given in the large intestine. 13

Figure 1.2.1. Summary of the developing digestive physiology alterations elders (Source: Shani-Levi et al., 2017) ${ }^{14}$. 25

Figure 5.1.1. A) Proteolysis extent (g free amino acid (AA)/100 g total protein) of hake, sea bass, salmon and sardine under different in vitro digestion models (control (C), Elderly 1 (E1), Elderly 2 (E2), Elderly 3 (E3) models) B) Molar percentage (\%) of the absorbable and non-absorbable lipid fractions of sea bass and salmon under the different in vitro digestion models. Absorbable fraction includes to AG2-MG\% + AG1-MG\% + FA\%, nonabsorbable fraction to AG1,2-DG\% + AG1,3-DG\% and lipolysis extent represent the summarize. a-c: different letters indicate significant differences of proteolysis/lipolysis extent between models. A-C: different letters indicate significant differences between foods $(p<0.05)$. 93 
Figure 5.2.1. Specific gastrointestinal conditions of the four in vitro digestion models applied to mimic healthy adult standardized conditions (C: control)) and elderly GI alterations (E1: Elderly 1; E2: Elderly 2; E3: Elderly 3)......119

Figure 5.2.2. Digested protein ( $\mathrm{mg}$ free amino acids/g product) of milk, yogurt, fresh cheese and aged cheese under different in vitro digestion models (C: control; E1: Elderly 1; E2: Elderly 2; E3: Elderly 3). Values at the bottom of the bars represent the proteolys extent (\%) achieved after in vitro digestion. Oral alterations (E1) in milk and yogurt were not evaluated because of the absence of mastication, and therefore the low saliva secretion in the oral cavity. a-d different lowercase letters indicate significant differences between models $(p<0.05)$. A-D different capital letters indicate significant differences between products $(p<0.05)$. .126

Figure 5.2.3. A) Lactose (mg glucose eq./g product) and B) calcium (mg Ca/g product), C) vitamin A ( $\mu$ g retinol/g product) and D) vitamin D3 ( $\mu \mathrm{g}$ cholecalciferol/g product) content in the bioaccessible fraction from milk, yogurt, fresh cheese and aged cheese digested under different in vitro digestion models (C: Control; E1: Elderly 1; E2: Elderly 2; E3: Elderly 3).Values at the bottom of the bars represents bioaccessibility (\%) with respect to the nutrient content in the product before in vitro digestion. a-c different lowercase letters indicate significant differences between models ( $p<0.05)$. A-D different capital letters indicate significant differences between products $(p<0.05)$. .135

Figure 5.2.4. Biplot of the different end-product resulting from digestion and their relationship with the binomial dairy product (milk, yogurt, fresh or 
aged cheese)-GI conditions (C: Control; E1: Elderly 1; E2: Elderly 2; E3: Elderly 3) obtained by means of the principal components analysis (PCA).

Figure 5.3.1. Specific gastrointestinal conditions set for the four in vitro digestion models of this study. 157

Figure 5.3.2. Proteolysis extent (\%) (g FAA's released/ $100 \mathrm{~g}$ protein) (A), essential and non-essential amino acids ratio (EAA/NEAA ratio) (B) and amino acids quantities ( $\mathrm{g} / 100 \mathrm{~g}$ of protein) classified by chemical structure (HHA (C), PCAA (D), NCAA (E), AAA (F) and SCAA (G)) found in hard-boiled, poached and omelet egg in vitro digested under C (control), E1 (Elderly 1), E2 (Elderly 2) and E3 (Elderly 3)) Gl conditions. EAA = (Val, Leu, lle, Thr, Met, Phe, Lys, His, Trp); NEAA = (Ala, Gly, Ser, Pro, Asn, Asp, Glu, Tyr, Cys). Hydrophobic amino acids (HAA = Ala, Val, Ile, Leu, Tyr, Phe, Trp, Pro, Met, Cys); Positively charged amino acids (PCAA = Lys, His); Negatively charged amino acids (NCAA = Asp, Asn, Glu, Gln); Aromatic amino acids (AAA = Phe, Trp, Tyr); Sulfur containing amino acids (SCAA = Cys, Met). Data shown are mean values from triplicates and the standard deviation. Different lowercase letters indicate significant differences between models and different capital letters indicate significant differences between cooking methods, with a significance level of $95 \%(p<0.05)$. 172

Figure 5.3.3. Vitamin A and D3 bioaccessibility achieved in hard-boiled, poached and omelet eggs in vitro digested under different $\mathrm{Gl}$ conditions (control (C), Elderly 1 (E1), Elderly 2 (E2), Elderly 3 (E3) models). Different lowercase letters indicate significant differences between models and 
different capital letters indicate significant differences between cooking methods, with a significance level of $95 \%(p<0.05)$.

Figure 5.3.4. Biplot and component weights of the different end-digestion products of proteins (proteolysis extent, EAA/NEAA ratio, HAA, PCAA, NCAA, AAA and SCAA contents), lipids (cholesterol content, absorbable, non-absorbable and total lipolysis extents) and micronutrients (vitamin A and D3 bioaccessibility) and their association with the binomial cooked eggs (hard-boiled, poached and omelet)-GI conditions (C, E1, E2 and E3) obtained by means of a principal components analysis (PCA). 179

Figure 5.4.1. TCA soluble protein $(\mathrm{g} / 100 \mathrm{~g}$ protein) of the bioaccessible fractions of gastric and intestinal digesta (A) and the FAA's of bioaccessible fraction of intestinal digesta ( $\mathrm{g} / 100 \mathrm{~g}$ protein) (B) found in chicken, turkey, pork and beef in vitro digested under C (control), E1 (Elderly 1), E2 (Elderly 2) and E3 (Elderly 3)) GI conditions. The data shown are mean values from triplicates and the standard deviation. Different lowercase letters indicate significant differences between digestion models and different capital letters indicate significant differences between meat origin, with a significance level of $95 \%(p<0.05)$. 209

Figure 5.4.2. ACE inhibitory activity (\%) (A) and DPPH antioxidant activity (mg TE/ g meat d.b.) (B) of the bioaccessible fractions of gastric and intestinal in vitro digesta of chicken and turkey, pork and beef under the elderly (E1, E2 and E3) and the standard GI conditions. The data shown are mean values from triplicates and the standard deviation. Different lowercase letters indicate significant differences between digestion models 
and different capital letters indicate significant differences between meat origin, with a significance level of $95 \%(p<0.05)$. 210

Figure 5.4.3. Biplot obtained by means of a principal component analysis (PCA) of the different gastric (A) and intestinal (B) end-digestion protein products and properties (FAA, EAA/NEAA ratio, HAA, PCAA, NCAA, AAA, SCAA, TCA soluble protein as well as ACE inhibition and DPPH antioxidant activities), and their association with the binomial meat type (chicken and turkey, beef and pork)-Gl host conditions (C, E1, E2 and E3). 221

Figure 5.5.1. Extent of proteolysis (\%) of the EAA and NEAA fractions of A: Legumes (chickpea, lentils, soya bean and white bean) and B: Grains (oats, spelt and quinoa) obtained with different in vitro digestion models (C, E1, E2 and E3). ${ }^{\text {acc }}$ Different lowercase letters indicate significant differences of EAA and the total extent of proteolysis between digestion models in each legume/grain $(p<0.05)$. 246

Figure 5.5.2. Extent of glycolysis (\%) in cooked legumes (chickpea, lentil, soya bean and white bean) and grains (oats, spelt and quinoa) obtained with different in vitro digestion models (C, E1, E2 and E3). Data presented as $\mathrm{g}$ of free glucose E/100 g initial starch. ${ }^{\text {abc }}$ Different lowercase letters indicate significant differences among digestion models with a significance level of $95 \%(p<0.05)$. 251

Figure 5.5.3. Calcium bioaccessibility (\%) of cooked legumes (chickpea, lentils, soya bean and white bean) and grains (oats, spelt, quinoa) digested with different in vitro digestion models (C, E1, E2 and E3). ${ }^{\text {abc }}$ Different 
lowercase letters indicate significant differences among digestion models with a significance level of $95 \%(p<0.05)$. .254

Figure 5.5.4. Biplot of the different end-products resulting from digestion and their relationship with the legume/grain samples (chickpea, lentils, soya bean, white bean, oats, spelt and quinoa) and the GI conditions (C, E1, E2 and E3) using principal components analysis (PCA) ...............................25 


\section{PREFACE}

\section{Justification of the study}

The world population is in continuous growth, albeit at a slower pace and the longevity is also increasing. It is expected that by 2050 will be more than twice as many persons above 65 as children under five. Being thus, the number of persons aged 65 years or over will surpass the number of adolescents and youth aged 15 to 24 years. For this reason, countries with aged populations should take measures to implement strategies and/or public programs to the growing proportion of older persons ${ }^{1}$. The mortality risks, health status, type and level of activity, productivity and other socioeconomic issues have changed significantly in the last years for the elderly. However, the development of alternative concepts and measures to face aging have to be considered for their implications in the living conditions, productivity and other contributions to society and their needs for social protection and health care ${ }^{2}$. Time of action must be now centered in preventive actions more than corrective ones and to prevent the collapsing of health systems ${ }^{3}$.

During aging, many changes occur including organs functions and their physiological response. First, body composition changes in the elderly, resulting in a loss of skeletal muscle tissue (sarcopenia) and an increase in fat mass and its distribution. Cognitive functions such as dementia and Alzheimer's disease can also occur. Moreover, gastrointestinal (GI) tract function is also altered, with reductions in sensory perceptions, salivation, oral health, absorption of nutrients, lactose intolerance, among others. Also, fluid imbalance (mainly characterized by an exceedance of fluid output), bones and joints problems (osteoporosis and arthritis, leading to falls and fractures), metabolic changes (diabetes mellitus type 2, dyslipidemia), cell growth with cancer and alteration in the cardiovascular 
system are included in the health problems that elderly people may present. Nonetheless, social, psychological and economic factors also impact the aging process ${ }^{3}$.

The problems presented during the $\mathrm{Gl}$ tract lead to maldigestion and malabsorption of macro- and micronutrients, affecting their general health status. Despite the irreversible nature of these changes, there is a lack of studies which report the repercussions of $\mathrm{Gl}$ alterations on macronutrients digestion and micronutrients bioaccessibility. In this context, the aim of this doctoral thesis was to assess the impact of the age-related $\mathrm{Gl}$ alterations on the digestibility of proteins, lipids and carbohydrates and the bioaccessibility of micronutrients such as calcium and fat-soluble vitamins (A and D3) from a selection of foods recommended for the elderly. Twentytwo foods from 6 groups (fishes, meats, dairy, egg, cereals and legumes). The in vitro simulation was employed as the main methodology to mimic some of the most common digestive conditions of this population group compared to that of healthy adults. The results will allow generating valuable information about the inherent properties of the foods and how these digestive issues impact the digestion of the foods.

This doctoral thesis was developed in the frame of the project "Alteraciones digestivas en poblacion sénior y su influencia en la digestibilidad de nutrientes" (AICO/2018/289) granted by Generalitat Valenciana. Also, a predoctoral grant (no. 306682) from the Mexican National Council of Science and Technology (CONACYT) was given to the PhD student. Both funds allowed the completion of this project and the doctoral thesis. 
1 INTRODUCTION 


\section{INTRODUCTION}

\subsection{Food digestion}

\subsubsection{Digestion process}

Food digestion is a complex combination of multi-step physicochemical processes involving food intake, breakdown, absorption of essential units, transport to the related organs, and disposal of residual waste. The human digestive system comprises of the digestive tract and other organs, is mainly controlled by a neural network and hormonal responses. The multistage procedure goes from the oral cavity through the throat, esophagus, stomach, small and large intestines to the anus. The auxiliary organs are the teeth, tongue, salivary glands, liver, gallbladder and pancreas. Each of the above-mentioned accessories performs a specific function, and together, they extract the nutrients from the digested foods and remove unused material ${ }^{4}$. The overall process of digestion mainly occurs in four steps as follows:

\subsubsection{Oral stage}

The oral stage is given throughout the mastication process which is controlled by the central nervous system and modulated by inputs from the mouth. Oral processing involves two functions: mastication and swallowing 5 . Some variations of the masticatory function could occur according to the intrinsic characteristics of the subject and the inherent properties of the chewed food. Within the most important subjects-related factors that modifies chewing includes age, gender and dental status. While hardness, rheological characteristics, food size, among others define the masticatory function ${ }^{6}$. 
During this stage, the saliva and teeth carry out the chewing process. For solid foods, a sequence of chewing is performed to achieve a reduction of the size of the food particles to generate a bolus safe to swallow ${ }^{6}$. On the other hand, liquid foods experiment a more rapid oral stage and it is useful if the food contains starch ${ }^{7}$. Saliva also initiates digestion by the action of salivary enzymes (alpha-amylase or lipase), helping to produce a breakdown of the chemical bonds of carbohydrates and lipids, leading into maltose and oligosaccharides and diglycerides and free fatty acids ${ }^{3}$. Figure 1.1.1 shows a general digestion mechanism occurring in the mouth.

The saliva components exert specific functions during the oral stage of the digestive system: electrolytes (e.g., bicarbonates, phosphates and urea) modulates the $\mathrm{pH}$ and the buffering capacity of saliva; macromolecule proteins and mucins serve to cleanse, aggregate and/or attach oral microorganisms and contribute to dental plaque metabolism; calcium, phosphate and proteins have a key role in the anti-solubility factor and modulate demineralization and remineralization; and immunoglobulins, proteins and enzymes provide antibacterial action ${ }^{8}$.

The average daily flow of the whole saliva varies between 1 and $1.5 L^{8}$. However, the flow rate of saliva depends on the characteristics of the foods (type of food, moisture content, structure, composition) but also the interindividual variation might affect the saliva:food ratio ${ }^{9}$. 

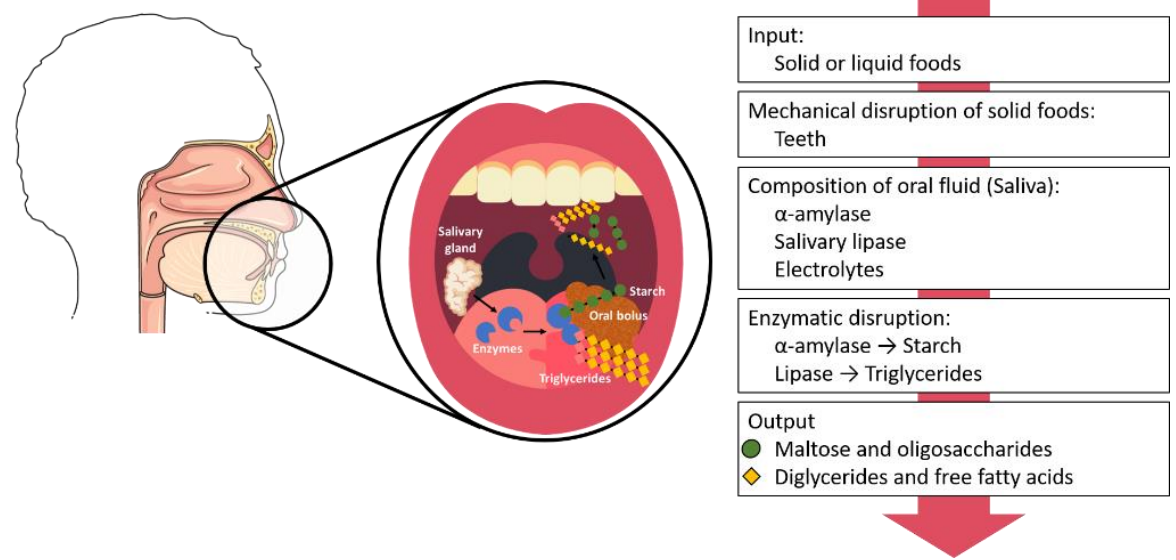

Figure 1.1.1. Diagram of the mechanical, chemical and enzymatic actions taking place in the mouth.

\subsubsection{Gastric stage}

The second most important stage of the digestive process is found in the stomach, which is a major digestive organ of the human body that executes a complex process involving both physical and chemical food breakdown ${ }^{10}$. Storing, mixing, emptying, reducing particles and breaking down the ingested foods are its main functions ${ }^{11}$. The stomach is divided into two parts, the proximal stomach (fundus and the upper half part) and the distal stomach (includes the gastric antrum and the lower part). The first one regulates the pressure to store food and the peristaltic contraction activity of the latter functions as a pump. The motility occurs with movements and contractions, and at the same time mixing, directing the food from proximal to distal stomach. Propulsions, emptying, mixing, retropulsion and grinding are the main objectives of those peristaltic wave movements ${ }^{12}$.

Foods suffer dramatic changes in their structure, preparing them to be easier digested and absorbed in the small intestine ${ }^{13}$. Some of the undergone changes that occur in the gastric environment are also given by 
the hydrochloric acid, enzymes (pepsin and gastric lipase), various electrolytes, mucus, intrinsic factor and hormones. Around $2 \mathrm{~L}$ of gastric fluids are secreted per day, secreting around $0.7 \mathrm{~L}$ after each meal ${ }^{14}$. The electrolytes that compose the gastric fluid are potassium, chloride, sodium, phosphate, carbonate, magnesium, calcium, thiocyanate, ammonium, urea, among others ${ }^{7}$. They are associated with the control of $\mathrm{pH}$ and regulation of the buffering capacity ${ }^{15,16}$.

Hydrochloric acid causes the acidity of the gastric fluid $(\mathrm{pH} 1.5-3.5)$ which is controlled hormonally by the parietal cells in the stomach wall. Like manner, the release of $\mathrm{HCl}$ stimulates the release of pepsin, unfolding and cleaving proteins into polypeptides ${ }^{12}$.

Gastric conditions start at $\mathrm{pH} 2$, turning into 6 due to the intrinsic properties of the oral bolus, being the buffering capacity the most impacting on this issue. However, the composition of gastric fluid and the gastric emptying progressively change the $\mathrm{pH}$ around 3 after 120 minutes ${ }^{17}$.

Food characteristics (components, volume, caloric content, solid:liquid ratio, type of dietary fibers, among others) highly influence the rate of gastric emptying. However, foods with solid structure are the most difficult to be emptied. The chewing efficiency and the degree of disintegration of the oral bolus are also important factors that could modify the kinetic of digestion and absorption of nutrients ${ }^{3}$

Pepsinolysis is mainly given in proteins and peptides that contain hydrophobic aromatic amino acids such as phenylalanine, tyrosine, and tryptophan ${ }^{18,19}$. Pepsin is capable of breakdown proteins into large chain peptides and fewer amino acids and short aminoacidic peptides ${ }^{20,21}$. Pepsinogen turns to active pepsin at $\mathrm{pH}$ between 1 and 6 at $37^{\circ} \mathrm{C}, \mathrm{pH} 2$ being the optimal to achieve the maximum activity. However, at $\mathrm{pH}$ between 4.5 and 5 , the activity is still present (up to 70 and $40 \%$, respectively) ${ }^{22}$. 
In physiological normal conditions, the time of gastric digestion could vary between 2 and $5 \mathrm{~h}$. The composition of the meal, size of the piece, and physiological parameters are factors that may influence the digestion time. Gastric stage generates particles with a size lower than 1 to $2 \mathrm{~mm}$ with the capacity to pass through the pylorus and hence be emptied from the stomach into the duodenum ${ }^{16}$.

The secretion of hormones (secretin and ghrelin) and neural signals regulate the stomach distension, thus stimulating the secretion of acid. Likewise, the presence of peptides and buffering capacity of the food could be implied. However, if a too low $\mathrm{pH}$ is achieved in the antrum and duodenum, the release of hormones and neural signals can be inhibited ${ }^{23}$

Thus, an acidic environment as well as the enzymatic actions, but also gastric lipase (from triglycerides to diglycerides and fatty acids), achieves the conversion of the oral bolus into gastric chyme. An overall physical, chemical and enzymatic gastric mechanism are gathered in Figure 1.1.2.

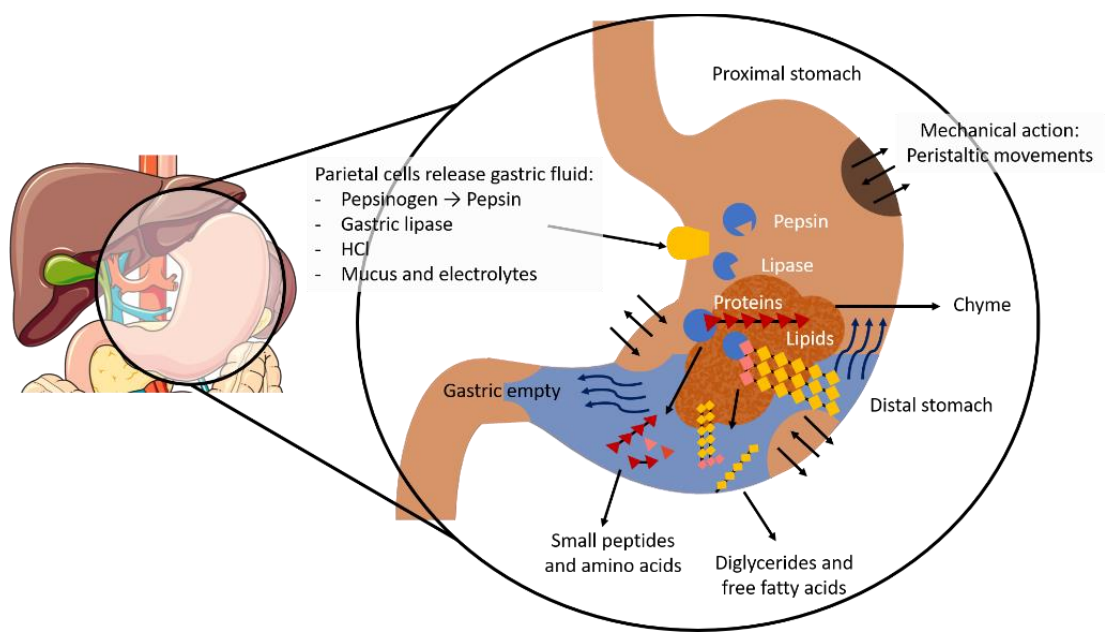

Figure 1.1.2. Overview of the mechanical, chemical and enzymatic mechanisms given in the stomach. 


\subsubsection{Small Intestinal stage}

The small intestine is 6-7 $\mathrm{m}$ long and goes from the pylorus to the ileocecal junction. During the small intestine digestion, chyle is formed when chyme is mixed with intestinal fluids. Chyle passes through three sections (duodenum, jejunum and ileum) at a rate of $2-25 \mathrm{~cm} / \mathrm{s}$. Peristaltic contractions also occur by the segmented action of the intestine, mixing and at the same time helping the nutrient absorption ${ }^{10}$. The first $25 \mathrm{~cm}$ of the small intestine corresponds to the duodenum, connecting the intestine to the liver (throughout the gallbladder) and pancreas, for receiving the bile and the digestive enzymes, respectively ${ }^{10}$. Also, a mucus-rich alkaline solution containing bicarbonate rises to near-neutral the $\mathrm{pH}$ of fluids ${ }^{24}$. The duodenum is the most important fraction because the digestion of the nutrients is carried out there. The absorption and still the breakdown of the foods are performed during jejunum and ileum. Following, jejunum and ileum, the two distal parts of the small intestine, are found as intraperitoneal. Even if there is no clear demarcation between them, they are macroscopically different. The jejunum connects the duodenum to the ileum and is about $2.5 \mathrm{~m}$ long. Here it is where the end-digestion products are mainly absorbed into the bloodstream. The ileum is about $3 \mathrm{~m}$ long and is mainly responsible for the absorption of bile acids and the remaining nonabsorbed nutrients. However, the digestion and absorption processes could be still present.

Throughout the three sections of the small intestine, physical and enzymatic reactions occur. Proteases (trypsin and chymotrypsin), lipases and amylases from the pancreas are the main responsible for the food nutrients hydrolysis. However, the peristaltic movements also help the enzymatic reactions by mixing and transport them towards the intestine ${ }^{21}$. The enzymes released by the pancreas, are a response of the cholecystokinin and secretin hormones ${ }^{25}$. The trypsin and chymotrypsin (considered as 
endopeptidases) cleavage the internal peptides bonds or exopeptidases to split single amino acids from the carboxyl-terminal end of peptides ${ }^{21}$. Having thus as end-digestion products smaller peptides (of mainly 3 amino acids) and free amino acids capable to be absorbed intact into the epithelial cells. Lipase breaks down triglycerides into free fatty acids, di- and monoglycerides. Bile salts play a key role in the emulsifying of fats, helping the lipase to cleavage sites ${ }^{26}$. Carbohydrates go from complex structures to simple sugars or monosaccharides (i.e., glucose). Starch is the main carbohydrate affected by pancreatic amylase. The carbohydrate enddigestion products are maltose, maltotriose and maltotetraose, but also some oligosaccharides of 5-9 glucose units ${ }^{27}$. All the end-digestion products are absorbed after the action (where needed) of the brush border enzymes present in the intestinal epithelium. Amylolytic (dextrinase, glucoamylase, isomaltase, sucrase and lactase) and proteolytic (aminopeptidase and dipeptidases (dipeptidylcarboxypeptidase and dipeptidylamino- peptidase)) action are exerted by brush border enzymes ${ }^{23,28}$. The amylolytic brush borders lead to glucose or other monosaccharides ${ }^{21}$, while the proteolytic brush border ones lead to free amino acids. However, some dipeptides and tripeptides are absorbed into the blood intact ${ }^{28}$. Complex carbohydrates that were not hydrolyzed pass to the large intestine to be fermented by the colonic microbiota ${ }^{23}$. A general panorama of the mechanical, chemical and biochemical reactions given in the small intestine is shown in Figure 1.1.3. 


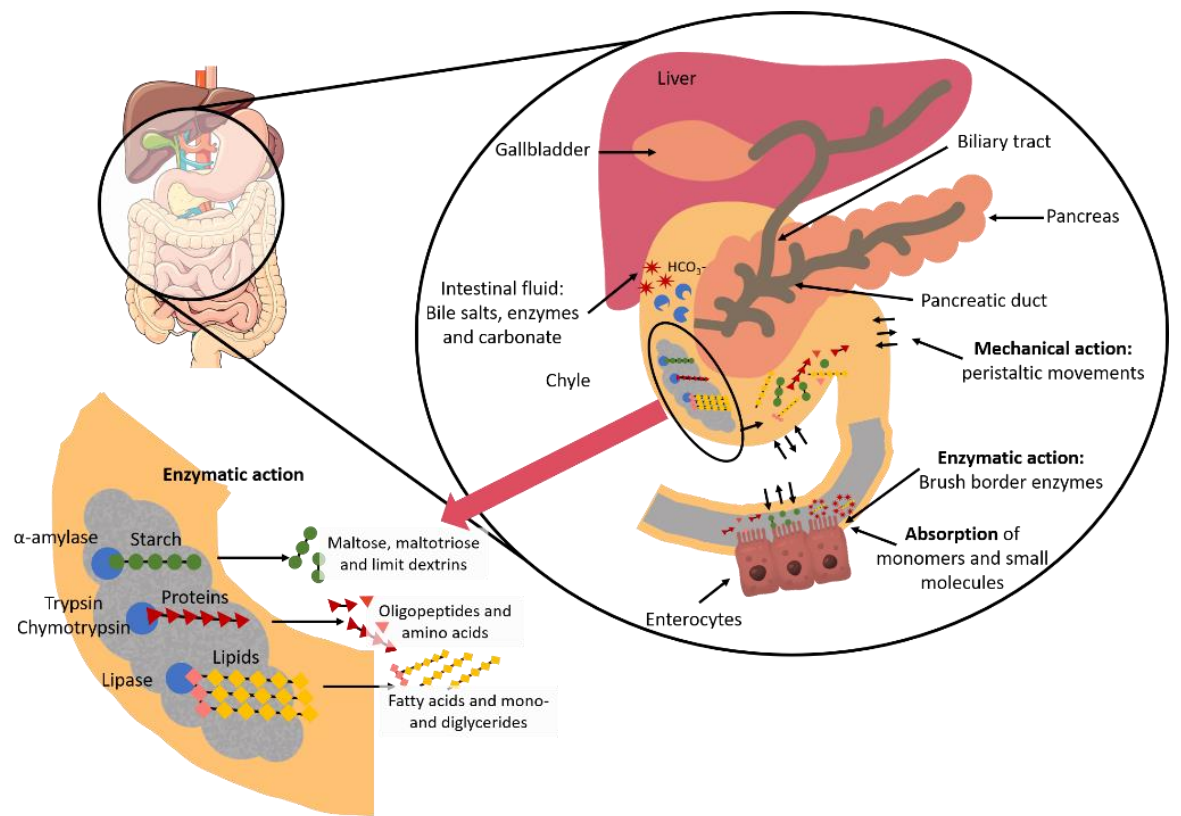

Figure 1.1.3. Overview of the mechanical, chemical and enzymatic mechanisms given in the small intestine.

\subsubsection{Large Intestinal stage}

The large intestine or colon is the last part of the digestive system and is approximately $1.5 \mathrm{~m}$ long. It is the prolongation of the small intestine that starts in the ileocecal valve and ends in the anus. Three parts compose the colon: ascending, transverse and descending colon. Between 1.2 and $1.5 \mathrm{~L}$ of ileal fluids enter and only between 0.2 and $0.4 \mathrm{~L}$ are excreted, the water absorption being highly important during this process. The main functions of the colon are to storage and process the residual non-digested matter during long periods. However, mixing and absorption of water, salts and some of the products generated also occur during this time.

The process is mainly given by the fermentative action of a consortium of microorganisms (microbiota) that take advantage of the non-digested 11 
fractions of the foods (mainly fiber and some proteins). The microbial ecosystem is composed mainly of bacteria groups, but also some fungi can be found ${ }^{29}$. Bacteroidetes, certain gram-negative bacteria, are in high amounts. However, Firmicutes, Proteobacteria and Actinobacteria could be also present. The phylogenetic composition of gut microbiota is highly variable according to the age of the humans (i.e., infants, adulthood, elderly) ${ }^{30}$. However, some other factors such as health status, diet and location cause variations in the gut microbiota ${ }^{31}$.

A saccharolytic process is one of the main activities of the gut microbiota by means of fermentation, being the undigested food the substrate. However, some bacteria are capable to ferment proteins, peptides and amino acids, giving some non-desirable putrefactive substances, such as ammonia, phenols, indoles, amines, and hydrogen sulfide, accumulate in gut contents 29 .

The carbohydrate colonic fermentation mainly depends on the composition of the ingested foods, the host and some other dietary factors. Polysaccharides are the major form of carbohydrates that entering in the large intestine and the rate of depolymerization of these carbohydrates impacts the rate of de availability for bacterial assimilation ${ }^{29}$. The main endfermentation products from the anaerobic environment in the colon are short-chain (C2-C6) fatty acids (SCFA). A large amount (80\%) of the colonic anion concentration is composed of acetate, propionate and butyrate, produced in nearly constant molar ratio 60:25:15. The SCFA production exert physiological function against intestinal neoplasia, ulcerative colitis, among other illnesses ${ }^{32}$. Specifically, the production of acetate enhances the ileal motility, increases the colonic blood flow, promotes better function in the immune system and increases blood antibody production against some type of cancer ${ }^{33}$. Even though there is a lack of studies in this field, exists a lot of relationship between the colonic scenery and the health of 
the hosts. An overview of the main mechanisms given in the colon are shown in Figure 1.1.4.

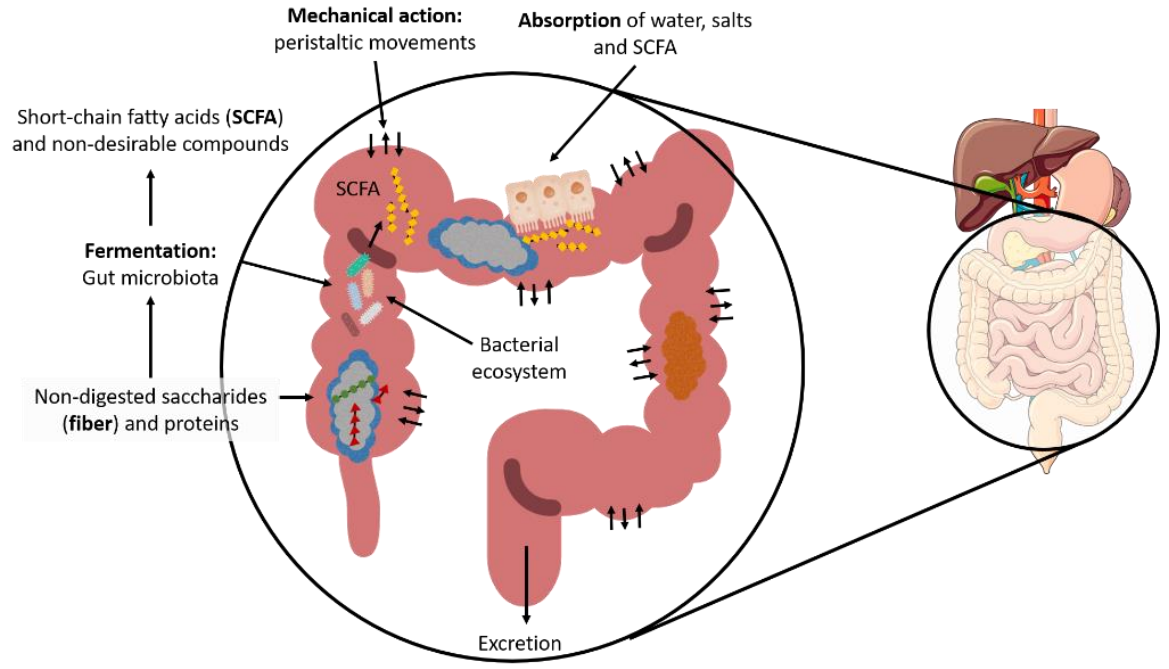

Figure 1.1.4. Overview of the mechanical action and microbial process given in the large intestine.

\subsubsection{Nutrients: Digestion and absorption}

The macronutrients (proteins, lipids and carbohydrates) digestion, as well as the release of micronutrients or bioactive compounds, are conditioned by some physical (peristaltic movements), chemical ( $\mathrm{pH}$ and digestion fluids) and biochemical factors (enzymes). The end-digestion products of the macromolecules result in simple units or small molecules capable to be absorbed throughout the intestine. Diffusion and transport allow the absorption of the digesta, water and bile (for recirculation).

\subsubsection{Proteins}

Proteins are polymers with a highly complex structure with functional diversity according to their chemical make-up. Their structure is composed 
of 20 different monomers (amino acids) ${ }^{34}$, which are composed by an amino group $\left(\mathrm{NH}_{2}\right)$ and a carboxylic group (-COOH). They are covalently linked by peptide and disulfide bonds. However, non-covalent interactions (hydrogen bonds, electrostatic interactions, hydrophobic interactions and weak nonspecific attractive and repulsive forces) may also define the composition and structure of proteins. Amino acids are grouped according to their characteristics, i.e., chemical structure. The sequence with a final threedimensional shape, defines the structure, origin and biological activity, according to environmental conditions ( $\mathrm{pH}$, temperature, salts, solvents) ${ }^{35}$.

In foods, the proteins determine texture, sensory and nutritional properties, as well as the sensibility to heat and other treatments. The proteins possess some functionality that are capable to impact the behavior during preparation, processing, storage and consumption ${ }^{36}$. For the protein consumption, the main interest is the nutritional point of view, due to the importance in physiological processes, using protein end-digestion products in specific biological functions, i.e., building muscular mass, cognitive functions, motility, immunomodulators, detox, among others. The structure of the proteins must be enzymatically and chemically broken in the $\mathrm{Gl}$ tract. Proteases (pepsin, trypsin and chymotrypsin) act on the protein bonds resulting absorbable short-chain peptides and free amino. Pepsin turns active when interacting with the acidic gastric $\mathrm{pH}(1.5-4)^{37}$. The specificity of pepsin is directed to proteins containing aromatic or hydrophobic Lamino acids ${ }^{38}$. On the other hand, trypsin and chymotrypsin are secreted in an inactive form (trypsinogen and chymotrypsinogen) by the pancreas. Trypsin cleaves the peptide bonds in which basic amino acids (lysine and arginine) contribute the carboxyl group; chymotrypsin cleaves peptide amide bonds where the side chain of the amino acid $\mathrm{N}$-terminal to the scissile amide bond is a large hydrophobic amino acid (tyrosine, tryptophan, and phenylalanine). The pancreatic proteolysis result in some free amino acids and a mixture of oligopeptides ${ }^{28}$. Some of these amino acids and 
peptides, could also exert some functional properties with benefits to the human body. The bioactivity associated with short-chain peptides is mainly metabolic regulation. Anti-hypertensive, opioid agonists or antagonists, immunomodulatory, antithrombotic, antioxidant, anti-cancer and antimicrobial activities have been reported ${ }^{39}$.

\subsubsection{Lipids}

Lipids in animal and plant foods are mainly found as triglycerides and in lesser extent as phospholipids and cholesterol ${ }^{40}$. The triglyceride structure is composed of a glycerol backbone and three fatty acid chains. The degree of lipid's unsaturation defines its nutritional value. The intake of saturated fatty acids is unneeded, while some of the unsaturated fatty acids (i.e., linolenic and linoleic) are key factors of a healthy diet ${ }^{41}$. Dietary fatty acids differ between them in the length and the number of carbons. Those with more than 14 are considered as long-chain fatty acids, while short-chain fatty acids (SCFA) with up to 6 carbons. The number double bounds defines if the fatty acid is saturated (without double bonds, SFA), monounsaturated (having one, MUFA) or unsaturated (having more than one, PUFA).

Triglycerides have to be broken in the GI tract, being this process highly efficient. In the oral phase, a salivary lipase is secreted which seems to not have a significant digestive role on human digestion, playing its role as fat taste and texture perception ${ }^{42}$. Following, a gastric lipase is released in the stomach, which is stable in gastric conditions ( $\mathrm{pH}$ between 2 and 7), being its optimal $\mathrm{pH}$ around $5{ }^{17}$. Gastric lipase mainly cleavages the sn-2 position in triglycerides ${ }^{43}$ and is capable to hydrolyze $10-30 \%$ of ingested triacylglycerols, producing mainly free fatty acids and diacylglycerols ${ }^{44}$. The intestinal digestion is favored by the gastric hydrolysis, facilitating the emulsification of fats and promoting pancreatic enzyme activity. In fact, the emulsification process could be started during the stomach because of peristaltic movements. However, the most important emulsification 
process of fats is given during the small intestine. The bile acids generates a colloidal system that helps to solubilize the lipids in an aqueous media, enhancing the enzymatic action ${ }^{28}$. Bile also acts on the hydrolyzed products, generating small micelles that allow the transport and a facilitated absorption ${ }^{45}$. Pancreatic lipase mainly cleavages the sn- 1 and sn-2 sites of triglycerides, but is capable to act on the sn- 2 site to a lesser extent ${ }^{46}$. The unfold of triglycerides could occur in different ways: resulting in total lipolysis, whereas three fatty acids are released and one glycerol molecule; partial lipolysis, in which only one fatty acid is released (generating apart a diglycerol) and two fatty acids released (generating apart a mono-glycerol). However, only the free fatty acids and the mono-glycerol molecules are absorbed by the intestinal epithelial cells ${ }^{47}$.

\subsubsection{Carbohydrates}

Carbohydrates are considered as the main contributors of the daily caloric intake (almost a half part). Most of them come from plant foods but other types of foods such as milk and meats (lactose and glycogen, respectively) could contribute to a lesser extent. Saccharides are organic compounds formed by one or more molecules with a single aldehyde or ketone group (monosaccharides, i.e., glucose, galactose and fructose). Those containing two monosaccharides, e.g., sucrose, lactose or maltose, are named disaccharides. When a saccharide structure contains between 2 and 10 units are known oligosaccharides and when the chain is longer than 10, are classified as polysaccharides. Starch is the most common polysaccharide in foods (about 50\%) ${ }^{28}$. However, some polysaccharides are gastrointestinal digestion resistant, especially in humans, due to the absence of some enzymes that break down certain linkages, mainly $\beta$. Some other gastrointestinal systems (i.e., ruminants) are capable to hydrolyze through chemical and enzymatic processes. 
Starches could vary as amylose and amylopectin, being the main difference their linear or branched structure, respectively. Amylose is composed of glucose units linked by $\alpha(1,4)$-glycosidic bonds while amylopectin is structured by glucose units with $\alpha(1,6)$-glycosidic linkages branched every 15-20 glucose units ${ }^{28}$. Both forms of starch are found naturally in foods, having variations between the amylose:amylopectin ratio. The changes in the ratio could influence and modify some important factors in foods (texture, stability, rheological and processing properties, oxygen permeability, water binding capacity and gel property) ${ }^{48}$. In addition, the ratio could influence the degree of glycolysis during the $\mathrm{Gl}$ tract, being greater when the food has more amylose than amylopectin ${ }^{49}$. Alphaamylase, secreted by the salivary glands and pancreas, is the responsible of the breakdown of carbohydrates. The salivary amylase impacts the saccharides in a lesser extent, due to a shorter time of residence in the mouth and the inactivation in the gastric environment (acid pH).

The starch is hydrolyzed to smaller molecules (oligomers) as maltose, maltotriose and $\alpha$-limit dextrins. The later present branch points resistant to $\alpha$-amylase. The amylolysis products are further hydrolyzed to glucose or other monosaccharides by the action of two brush border enzymes (maltase-glucoamylase and sucrase-isomaltase) ${ }^{50}$. Once hydrolyzed and released, monomers are absorbed through the intestinal epithelial cells, generating an increase in the glucose in the bloodstream concentration, for their use as an energy source by the cell of tissues and organs. Nevertheless, undigested carbohydrates follow their digestion process in the large intestine, being fermented by the colonic microbiota obtaining energy and producing short-chain fatty acids ${ }^{50}$.

\subsubsection{Micronutrients and bioactive compounds}

In addition to the macronutrients, foods include other minor components such as vitamins (water-soluble and fat-soluble) and minerals. They 
participate as constitutive elements of tissues and are implied in the activity of enzymes and hormones. The most common micronutrients in foods are water-soluble (C, B, biotin, pantothenic acid, and folic acid) and fat-soluble $(A, D, E$ and $K$ ) vitamins and minerals (calcium, potassium, magnesium, phosphor, sodium, sulfur). Besides, bioactive compounds (carotenoids, polyphenols, terpenes, lignans, organosulfur compounds, glucosinolates and saponins) do not have contribution to the nutritional function but exert a beneficial effect on cell activities and physiological functions. Like manner, bioactive compounds are found in much lower amounts, compared to macronutrients.

The bioavailability of these bioactive compounds depends on the food matrix and structure. The degree of deconstruction and hydrolysis during the digestive process, will determine the bioaccessibility of these substances. First, the chewing action broke down the food structure resulting in semi-solubilization of macro- and micronutrients in salivary fluids. Following, the physical, chemical and enzymatic actions may enhance the extraction, solubility and stability of micronutrients during gastric and intestinal stages. As the food matrix is missing, the micronutrients are released to the aqueous media. However, these substances absorption may be affected by interactions within the food structure and end-digestion products. Thus, considering the possible interactions, the intake of micronutrients and bioactive compounds is highly needed due to their implication in essential functions. Moreover, they enhance the health of the host by their antibacterial, anti-inflammatory, antioxidant, among others effects ${ }^{51}$.

\subsubsection{Factors affecting food digestion}

There are two main types of factors that affect food digestion: food-related and host-related factors. 


\subsubsection{Food-related factors}

In complex systems such as food matrices, several factors could conditionate nutrients digestion. These factors include food-inherent properties and dietary patterns. The most significant food characteristics in the nutrient digestibility and bioaccessibility are the chemical composition, physical structure, processing and interactions of the nutrients before and after digestion ${ }^{52-54}$.

Food composition results into different enzyme:substrate ratios, even if the digestive fluids are secreted according to the composition by hormonal signals ${ }^{55,56}$. Additionally, the food composition depends on the origin of foods (e.g., vegetal or animal) which directly impact on the response to the digestion process. For instance, digestibility of vegetal protein differs from animal ones, due that plant foods have cell walls, present some antinutritional factors and their amino acidic composition is different ${ }^{57}$.

Besides, food matrix could conditionate digestion process and kinetics ${ }^{58}$. Harder and structured matrices are more difficult to be disrupted, being nutrients less available to the digestive factors (physical, chemical and biochemical) ${ }^{59}$. Being thus, foods with a simple matrix (liquids and semi liquids) easier to digest ${ }^{37}$.

Some modifications in the food characteristics could occur during processing (composition, physical properties, stability of nutrients during storage, among others). Processes such as refrigeration, freezing, heating, curing or chemical treatments (i.e., ozonation) could play an important role in food digestion. Thus, freezing could modify the texture and other physicochemical parameters of fruits. In contrast, phytochemicals (carotenoids and flavonoids) were similar in fresh and frozen vegetal foods ${ }^{60}$. On the other hand, heating seems to increase nutrients digestibility (i.e., denaturation of proteins, jellification of starches), but could lead to 
degradation at the same time (oxidation of vitamins or phytochemicals) ${ }^{61}$. Other processes, such as milling, used to decrease the particle size, might enhance digestion because of an increase of the surface area and therefore promoting enzyme and substrate interaction ${ }^{62}$. Some other processing methods, such as sprouting ${ }^{63}$, fermentation ${ }^{64,65}$, curing ${ }^{66}$, homogenization ${ }^{67}$ and emulsification ${ }^{68}$ have been reported to impact on the digestibility and bioaccessibility of nutrients in a different extent depending on many process variables.

On the other hand, physical and chemical interactions determine food digestibility, bioaccessibility, transport and absorption of nutrients. Three different interactions have been stated: interactions (i) between nutrients within the food matrix, (ii) between nutrients with other components during digestion and (iii) among end-digestion products (after the digestion and during the release and solubilization).

The interactions before digestion occurring between nutrients are given in the food matrix structure ${ }^{69}$. For example, lipolysis rate is dependent on the proteolysis or glycolysis extents if the matrix presents the lipids trapped. As long as the network breaks down, the lipids are released from the food matrix, becoming accessible to lipases ${ }^{70}$. In emulsion food systems, the active or inactive lipids interactions determine the properties affecting digestibility ${ }^{71}$. On the other hand, polyphenols may be found in a natural manner interacting with carbohydrates on the wall cells. The release depends on the rupture of the matrix, e.g., by grinding, pressing and chemical and enzymatic actions ${ }^{72}$.

Interactions that occur between nutrients and other components during the $\mathrm{Gl}$ tract must be also considered. Once released, some nutrients interact with other physiologically released compounds to be absorbed. Cyanocobalamin (Vitamin B12) binds with a glycoprotein (intrinsic factor) secreted in the stomach to turn into an absorbable structure. Once bonded 
to the intrinsic factor, vitamin B12 is capable to be absorbed and used in specific functions, one of them is oriented against pernicious anemia ${ }^{73}$.

Furthermore, after digestion and release of micronutrients and bioactive compounds, some of them could interact together. For example, the free calcium could interact with long-chain fatty acids, forming insoluble calcium soaps, removing them from the oil-water interface and worsening the lipid digestibility ${ }^{74}$.

\subsubsection{Host-related factors}

There are numerous host-related factors that could condition the efficiency of digestion process, bioaccessibility and bioavailability of nutrients. The most common are sex, age, genotype, lifestyle, physiological state and general health status.

Some diseases or conditions such as lactose intolerance, pancreatic insufficiency, gastric surgeries (intended to treat obesity), helicobacter pylori infection, allergies, autoimmune disorders (celiac sprue), Crohn's disease, atrophic gastritis, hyperthyroidism, cirrhosis, obesity and diabetes are linked to interferences with the absorption and/or metabolism of nutrients ${ }^{14}$.

Lactose intolerance is a response to a lack of one of the brush-border enzymes (lactase) that breaks down the dairy-origin saccharide. This intolerance has high prevalence in Asiatic populations ${ }^{75}$. Endocrine Pancreatic Insufficiency (EPI) occurs in cystic fibrosis patients. In addition to the decreased pulmonary function, these patients present obstruction in the pancreas by a dense mucosa, affecting the release of sodium bicarbonate and pancreatic juice. This health condition highly impacts the health status of the patients due to their reduced intestinal capacity to digest and absorb nutrients, mainly lipids ${ }^{76}$. Gastric surgeries (gastric bypass or sleeve gastrectomy) can also modify the way nutrients are digested. 
The size and shape of the stomach are altered, modifying the gastric empty resulting in less time of digestion with an elevated pH (3.5-4) ${ }^{14,77}$. Crohn's disease results from genetic susceptibility, environmental factors, and intestinal microbiota composition change, resulting in an abnormal mucosal immune response and a compromised epithelial barrier function ${ }^{78}$. Atrophic gastritis, commonly developed together with Helicobacter pylori infection, lead to a reduced gastric acid secretion and hypochlorhydria, altering nutrients digestion ${ }^{79}$. Therefore, certain diseases or physiological conditions can alter nutrients digestion.

Furthermore, scientific literature reports that humans' digestion changes along life. Infants, toddlers, adults and the elderly present different physiological paths to achieve nutritional requirements. New-born subjects present a lack of dental pieces, the digestive fluids with a gastric $\mathrm{pH}$ slightly elevated (3.5-6.5), a reduced pepsin release (10-20\% less than for adults) and different type and concentration of enzymes (different lipase, less amylase and other brush border enzymes). The size of the stomach is smaller making the time between meals also shorter ${ }^{14}$. Gut microbiota in infants is in constant change, acquiring some charge according to the mode of birth and the mother gut microbiota, turning different composition when a transition to a more solid and varied diet occur ${ }^{30}$. However, the gastrointestinal conditions became to their optimum point in adulthood and get worse in the elderly. A deterioration in the oral health status, an imbalance in the saliva fluids, less peristaltic movements, a lower bile and enzymes concentrations, different $\mathrm{pH}$, longer time of digestion and different gut microbiota composition are common in the elderly. Consequently, a worsened digestive process and health status. 


\subsection{Gastrointestinal alterations in elders and their impact on digestibility and bioaccessibility of nutrients}

Elders' health is now a global concern and have been taken as a world challenge due the implications on pharmacology and overall health care ${ }^{14}$. Consequently, elders will represent a huge part of the population. For this, economic, political and social changes are motivating to act in a preventive form to avoid the collapse of the implied systems (social, economic, of assistance, political and health) ${ }^{2}$ and ensure a better quality of life. Therefore, understanding the physiological changes along ageing, including those affecting the gastrointestinal functions, plays a key role in this important and preoccupant topic. Thus, body composition undergoes changes due to a loss of skeletal muscle tissue (sarcopenia) and an increase in fat mass, among others. Changes in cognitive function like dementia and Alzheimer's disease are also given. Elders also present alterations in the gastrointestinal tract consisting of an imbalance of fluids (greater fluid output), together with osteoporosis and arthritis (which may entail falls and fractures), diabetes mellitus type 2, dyslipidemia, altered cardiovascular system and cancer ${ }^{3}$. On the other hand, elders represent a vulnerable collective in many countries, being specially affected by social, psychological and economic issues. These above-mentioned aging problems can impact their quality of life in a simple or in a synergic way (Table 1.2.1). 
Table 1.2.1. Social, psychological and physiological issues responsible of malnutrition in elders (Source: Rémond et al. (2015)) ${ }^{3}$.

\section{Social factors}

- Lack of knowledge about food, cooking and nutrition

-Isolation/loneliness

- Poverty

- Inability to shop and/or prepare food

\section{Psychological factors}

-Dementia

-Depression

- Confusion

-Anxiety

\section{Physiological factors}

- Gastrointestinal dysfunction, e.g., malabsorption

- Poor appetite and poor diet

- Oral problems (teeth loos and dysphagia)

- Loss of taste and smell

- Respiratory disorders

- Endocrine disorders, e.g., diabetes mellitus type 2

- Neurological disorders, e.g., Parkinson disease

-Infections, e.g., urinary tract infections

- Physical disability to feed self

- Drug interactions

- Nausea and vomiting

-Altered/increased metabolic demands

- Other diseases, e.g., cancer 
Gastrointestinal alterations are highly relevant because if malnutrition and malabsorption are given in the elderly, some other factors are triggered. The most common oral, gastric, small intestine and large intestine (colon) alterations appearing with ageing are presented in Figure 1.2.1.

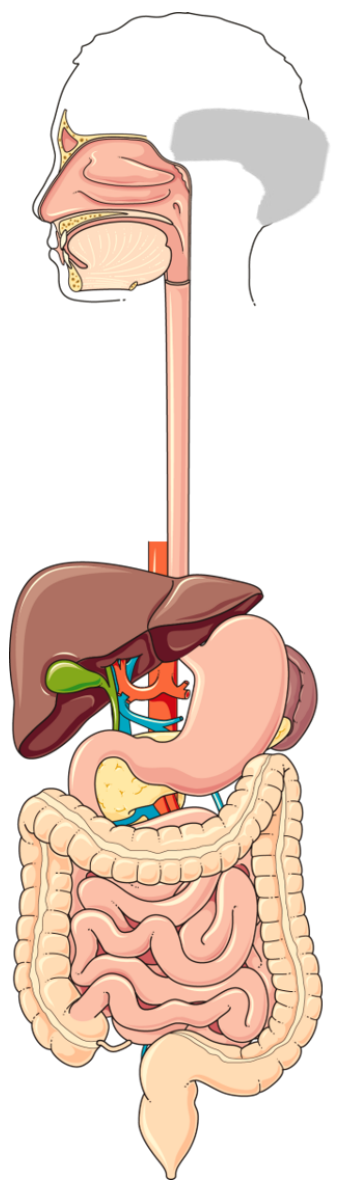

\section{Oral stage}

- Concentrated saliva with amylase levels to $150 \%$

- Changes in ionic composition of electrolytes

$$
\begin{array}{ll}
\text { Gastric stage } \\
\text { - } & \text { Reduced pepsin concentration (to } 75 \% \text { ) } \\
\text { - } & \text { Reduced gastric lipase concentration (to 15\%) } \\
\text { - } & \text { Less peristaltic movements } \\
\text { - } & \text { Higher pH gradient (from } 6.2 \text { to } 2 \text { ) } \\
\text { - } & \text { Longer residence time (3 } \mathrm{h})
\end{array}
$$

\section{Small intestine stage}

- Reduced proteolytic enzymes and bile (to $50 \%$ )

- Reduced lipase levels to higher pH (6.5)

- Longer residence time ( $3 \mathrm{~h})$

- Less peristaltic movements
Large intestine (colon) stage
- Modified composition of microbiota with less diversity
- Less peristaltic movements
- Longer residence time

Figure 1.2.1. Summary of the developing digestive physiology alterations elders (Source: Shani-Levi et al., 2017) ${ }^{14}$. 


\subsubsection{Oral status in elderly}

Mastication is altered in the elderly with a bite force decreased and less mandibular reflexes, the oro-sensory receptors worsened, the muscles involved in chewing and the tongue activities decreased, tooth damage, malocclusion and less amount of saliva secretion ${ }^{3,80}$. Thus, factors can be grouped into two types: the oral health status and the properties of saliva.

Within the oral status, tooth loss (edentulism) affects more than one-third of the elderly population, affecting the dietary intake, leading to suboptimal absorption of nutrients ${ }^{81}$. In addition, the diet is modified to compensate the impaired oral health and limited oral functional capacities. Hard-type foods consumption is reduced increasing the soft-type ones. Consequently, the protein intake decreases and the amount of fat and additives increase 3 .

On the other hand, the altered salivation in the elderly is characterized by changes in the amount and composition. Less saliva is secreted with an imbalance of electrolytes and more salivary enzyme concentration ${ }^{14}$.

It has been reported that an oral status affected (e.g., with tooth loss and with less amount of saliva) do not cause severe problems because elderly people compensate with more chewing cycles. Although, even if the oral host-conditions can be compensated, the intrinsic characteristics of the food must be considered.

\subsubsection{Gastric alterations in elderly}

The elder's stomach suffers some alterations that may impact the digestive function. Gastric atrophy is characterized by a decrease in fluid secretions, with higher $\mathrm{pH}$ gradient (between 6 and 2.2), pepsin (to 75\%) and gastric lipase (to $15 \%$ ) reduction, less peristaltic movements, as well as the changes in the mucus production and mucosal prostaglandin levels ${ }^{14}$. Also, a slower 
passage in higher residence time is produced by a reduction in the gastric emptying. It is thought that the supply of blood may be also reduced, which can be aggravated when the generalized atherosclerotic disease is present ${ }^{3,12}$. Furthermore, Helicobacter pylori infection, one of the most difficult to eradicate, is highly frequent among the elderly, generating weight loss and failure to thrive ${ }^{12}$.

\subsubsection{Small intestine changes in elderly}

Even if scarce literature reports the evaluation of the aging changes, some intestinal alterations have been stated ${ }^{3,82,83}$. First, the transit time seems to be longer than in young adults, oscillating between 2 and $6 \mathrm{~h}$, due to lower peristaltic movements. Also, the intestinal secretions result in alterations (i.e., bile and pancreatic secretions), being lower the lipase and chymotrypsin concentrations (reduced by 15 and $23 \%$, respectively) and the amount of bicarbonate and enzymes almost half reduced (45\%) ${ }^{84}$. Actually, the consensus methodology by the INFOGEST group establishes the conditions to perform an in vitro digestion model to elucidate the impact of these disorders on the elders' nutrition ${ }^{14}$. This model suggests lowered peristaltic movements, reduced proteolytic enzymes (to 50\%), reduced lipase levels to higher $\mathrm{pH}(6.5)$, longer transit time ( $3 \mathrm{~h}$ ) and lowered bile concentration (to $50 \%{ }^{14}$. The $\mathrm{Gl}$ conditions and their alterations in the elderly are shown in Figure 1.2.1.

\subsubsection{Colonic changes in elderly}

The large intestine (colon) is also affected by aging. A reduction in the peristaltic movements is triggered by less physical activity. Consequently, a tendency for a longer colonic transit time in older patients occur. Moreover, the composition of the colonic microbiota change. Less biodiversity and a compromised stability occur, being highly altered the ratio between 
Firmicutes and Bacteroidetes (the two dominant divisions of the gut microbiota) ${ }^{3,14}$.

The differences in the gut microbiota composition are associated to the change in the diet. Having thus, a limited range of foods promoting colonic microbial growth. In addition, the accumulative disorders of the bowel functions give a digest with different characteristics, being this the substrate for the colonic microbiota. Changes in gut microbiota composition are indicators elements to understand and improve the health of the elders ${ }^{31}$.

\subsection{In vitro digestion model for elderly}

To assess the effect of the gastrointestinal conditions on the digestion of proteins, lipids and carbohydrates, as well as the bioaccessibility of micronutrients and bioactive compounds, some gastrointestinal in vitro digestion models have been proposed by the INFOGEST group, simulating the conditions of healthy adults ${ }^{7,85}$. Besides, in vitro digestion models have proposed for specific populations groups such as infants, elders and other abnormalities in the digestive system (pancreatic insufficiency, gastric surgeries) ${ }^{14,86}$. Tables 1.3.1 and 1.3.2 gather the oral, gastric and intestinal conditions of healthy adults and elderly proposed by the INFOGEST consensus.

In addition, some studies have been reported the importance of the oral status and the impact on the digestive system and in the general health status. These studies also highlight the different behavior of the foods according to their physicochemical and compositional characteristics.

The use of the in vitro methodology allows studying a huge number of samples in parallel, with high reproducibility and with good correlation to in vivo studies. In addition, the in vitro studies allow to know the exact status of the nutrient at specific moments of the digestion. Thus, in vitro 
methodologies can be useful first to study the phenomena occurring during the digestive system. Following, the information can be used for a posterior in vivo study.

The generated information possesses high research value due to the nutritional importance to establish dietary recommendations or to the design of products according to the specific needs of certain population groups.

Table 1.3.1. Summary of the oral, gastric and intestinal conditions to perform an in vitro digestion simulation with the healthy standard conditions established by the INFOGEST group ${ }^{7,85}$.

\begin{tabular}{cccc}
\hline Parameter & Oral stage & Gastric stage & $\begin{array}{c}\text { Small intestine } \\
\text { stage }\end{array}$ \\
\hline pH & 7 & 3 & 7 \\
\hline Time of residence & $2 \mathrm{~min}$ & $2 \mathrm{~h}$ & $2 \mathrm{~h}$ \\
Total volume & $\sim 10 \mathrm{~mL}$ of & $\sim 20 \mathrm{~mL}$ of & $\sim 40 \mathrm{~mL}$ of chyle \\
& bolus $1: 1$ & chyme & $1: 1$ \\
& $(5 \mathrm{~g} \mathrm{food}+5$ & $1: 1$ & $(20 \mathrm{~mL}$ chyme + \\
& $\mathrm{mL} \mathrm{SSF})$ & $(10 \mathrm{~mL}$ bolus & $20 \mathrm{~mL} \mathrm{SIF)}$ \\
Enzymes and & Salivary & Pepsin $(2000$ & Pancreatin $(100$ \\
concentration & amylase at 75 & $\mathrm{U} / \mathrm{mL})$ & $\left.\mathrm{U}_{\text {trypsin }} / \mathrm{mL}\right)$ \\
Bile salts & $\mathrm{U} / \mathrm{mL}$ & & \\
\hline
\end{tabular}


Table 1.3.2. Summary of the oral, gastric and intestinal conditions to perform an in vitro digestion simulation with the elderly conditions suggested by the INFOGEST group ${ }^{14}$.

\begin{tabular}{cccc}
\hline Parameter & Oral stage & Gastric stage & $\begin{array}{c}\text { Small intestine } \\
\text { stage }\end{array}$ \\
\hline pH & 7 & 6 & 7 \\
\hline Time of residence & $2 \mathrm{~min}$ & $2 \mathrm{~h}$ & $\mathbf{4 ~ \mathbf { ~ }}$ \\
Total volume & $\sim 10 \mathrm{~mL}$ of & $\sim 20 \mathrm{~mL}$ of & $\sim 40 \mathrm{~mL}$ of chyle \\
& bolus $1: 1$ & chyme & $1: 1$ \\
& $(5 \mathrm{~g}$ food +5 & $1: 1$ & $(20 \mathrm{~mL}$ chyme + \\
& $\mathrm{mL} \mathrm{SSF})$ & $(10 \mathrm{~mL}$ bolus & $20 \mathrm{~mL} \mathrm{SIF)}$ \\
Enzymes and & Salivary & Pepsin (1500 & Pancreatin (50 \\
concentration & amylase at & $\mathbf{U} / \mathbf{m L})$ & $\left.\mathbf{U}_{\text {trypsin }} / \mathbf{m L}\right)$ \\
Bile salts & $\mathbf{1 1 2 . 5 ~} \mathbf{~} / \mathbf{m L}$ & & \\
\hline
\end{tabular}

\subsection{Changes in elder's diet}

Because of the physiological changes in the elderly the variety of foods is highly reduced. In addition, the impossibility or independence to cook, some economic issues, the administration of medicines, a diminished appetite, loneliness and depression are other factors that must be considered. The type of foods in which the elder's nutrition is based includes foods with less proteins and fiber and more fat, starch and additives. The physical characteristics of the foods present high relevance. In fact, smother foods can be easier chewed, swallowed and digested by elders. Consequently, elders can enter into a malnutrition status, defined as "a state of nutrition in which a deficiency of energy, protein and other nutrients causes measurable adverse effects on tissue and body form (body shape, size and 
composition) and function and clinical outcome" ${ }^{87}$. For this, considering the aging changes, the clinical recommendations suggest keeping the supply of proteins (i.e., for the preservation of muscle mass), vitamins and minerals (i.e., for bone health) at least the same or preferably slightly increased compared to the intakes of healthy persons ${ }^{88}$.

The protein-energy malnutrition is highly common in the elderly resulting in significant personal, social and economic problems ${ }^{87}$. In addition to the physiological changes, the higher cost of rich-protein foods is an important factor. Within the aging changes, sarcopenia and frailty are considered as the most critical and adequate amounts of proteins and energy intake are considered against them. Sarcopenia is characterized by the progressive and generalized loss of skeletal muscle mass and muscular function leading to risks of physical disability, falls and frailty. Is highly associated with osteoporosis disease, both factors being determining the life quality of the elderly. In addition, asthenia is a symptom in which the physical condition of the person disables the capacity to walk, run or another physical effort $3,89,90$.

The dietary recommendations for elders suggest reducing the food consumption that tends to increase the risk of obesity, hypertension and related chronic conditions. These recommendations advice to avoid saturated fats (i.e., meats and dairy products with high lipid content, processed meat), trans fat (i.e. hydrogenated oils, margarine, shortening, and those products containing them), refined carbohydrate foods (i.e. soft drinks, fruit juices, bread with low fiber content and products with white flour, white rice), sodium (salt and sodium compounds in canned and other processed foods, table salt), and phosphorus (cola, processed meats and commercially baked products) ${ }^{91}$. In contrast, the recommendations also propose higher protein intake (1-1.5 g protein per kg body weight per day) than for younger adults (0.8 g protein per kg body weight per day), 
representing the $15-20 \%$ of total energy intake ${ }^{86}$. In addition, high amounts of vitamins and minerals (especially those involved in bone health, i.e., vitamin $\mathrm{D}$ and calcium) are recommended. Furthermore, it has been reported that other nutrients are found as non-adequate intakes, such as omega-3 fatty acids, dietary fiber, carotenoids (vitamin A precursors), magnesium, potassium and vitamins $B 6, B 12$ and $E{ }^{92}$. Even if supplements may be usually needed (in case of nutrient deficiencies and/or and inefficient absorption and use of nutrients because of medications), elderly people must tend to dietary habits in which fruit, vegetables, legumes, whole grains, nuts or seeds, fish, lean meat, poultry, and low-fat fluid dairy products would be included ${ }^{91}$. Those foods are considered a good source of nutrients according to elderly requirements. Foods such as soy, dairy products and meat have the highest levels of dietary proteins with good amounts of indispensable amino acids, and other micronutrients ${ }^{86}$. They present good amounts of essential amino acids including leucine, isoleucine and valine. These amino acids, also known as branched-chain amino acids (BCAA), play a significant role as important substrates and regulators in protein synthesis with heavier anabolic effects ${ }^{93}$.

Considering the recommendations for the elders, dietary animal protein (meats, fish, dairy and egg) is the primary source of high biological value protein, iron, vitamin B12, folic acid, biotin and other essential nutrients. Egg protein, highlights for its advantages due to be less expensive, compared to other high-quality protein sources (meat, poultry and seafood). However, legumes (considered as rich-protein foods) can be useful to the protein dietary contribution, but also certain cereals/pseudocereals can present relatively large amounts of proteins (i.e., oats, quinoa, spelt), considering still their high contribution of dietary fiber, vitamin $B$, and numerous dietary minerals ${ }^{94}$. 
In this sense, some organisms such as the European Society for Clinical Nutrition and Metabolism and the Spanish Society of Geriatrics and Gerontology (SEGG for its acronym in Spanish) advise elders to increase the consumption of rich-protein foods ${ }^{95}$, and especially those rich in essential amino acids such as leucine or tryptophan ${ }^{90}$.

Accordingly, twenty foods were selected to screen the impact of the elderly GI disorders on different food matrices of six different classifications: fishes, dairy, eggs, meat, cereals and legumes. In each group, the most consumed by Spanish elderly population were chosen (Table 1.3.1) according of questionnaire in which 50 Spanish elders were asked to indicate the foods consumed the most in six food categories contributing to the protein intake. Some of them require processing for its habitual consumption such as cooking (i.e., cereals and legumes) or steam cooking (meat and fish), before digestion. Likewise, the influence of the processing on the digestion of macro- and micronutrients of the egg was considered an interesting topic. 
Table 1.4.1. Rich-protein foods selected to be digested according to the selection performed by Spanish elders throughout a questionnaire.

\begin{tabular}{ll}
\hline Food category & Food \\
\hline Fishes & Salmon \\
& Sardine \\
& Sea bass \\
& Hake \\
\hline Milk and dairy products & Milk \\
& Yogurt \\
& Fresh cheese \\
& Aged cheese \\
\hline Egg & Hard-boiled \\
& Poached \\
& Omelet \\
\hline Meats & Chicken \\
& Turkey \\
& Pork \\
& Beef \\
\hline Cereals & Oats \\
& Quinoa \\
\hline Legumes & Spelt \\
\hline & Chickpea \\
& White bean \\
& Lentils \\
& Soya bean \\
\hline
\end{tabular}




\section{References}

(1) UN. World Population Prospects 2019: Highlights (St/Esa/Ser. A/423). 2019.

(2) UN. World Population Ageing 2019: Highlights (ST/ESA/SER.A/430). Official; 2019.

(3) Rémond, D.; Shahar, D. R.; Gille, D.; Pinto, P.; Kachal, J.; Peyron, M. A.; Dos Santos, C. N.; Walther, B.; Bordoni, A.; Dupont, D.; TomásCobos, L.; Vergères, G. Understanding the Gastrointestinal Tract of the Elderly to Develop Dietary Solutions That Prevent Malnutrition. $\begin{array}{lllll}\text { Oncotarget 2015, } & 6 & \text { (16), }\end{array}$ https://doi.org/10.18632/oncotarget.4030.

(4) Sensoy, I. A Review on the Food Digestion in the Digestive Tract and the Used in Vitro Models. Curr. Res. Food Sci. 2021. https://doi.org/10.1016/J.CRFS.2021.04.004.

(5) Peyron, M. A.; Gierczynski, I.; Hartmann, C.; Loret, C.; Dardevet, D.; Martin, N.; Woda, A. Role of Physical Bolus Properties as Sensory Inputs in the Trigger of Swallowing. PLoS One 2011, 6 (6). https://doi.org/10.1371/journal.pone.0021167.

(6) Woda, A.; Foster, K.; Mishellany, A.; Peyron, M. A. Adaptation of Healthy Mastication to Factors Pertaining to the Individual or to the Food. Physiol. Behav. 2006, 89 (1), 28-35. https://doi.org/10.1016/j.physbeh.2006.02.013.

(7) Minekus, M.; Alminger, M.; Alvito, P.; Ballance, S.; Bohn, T.; Bourlieu, C.; Carrière, F.; Boutrou, R.; Corredig, M.; Dupont, D.; Dufour, C.; Egger, L.; Golding, M.; Karakaya, S.; Kirkhus, B.; Le Feunteun, S.; Lesmes, U.; Maclerzanka, A.; MacKie, A.; Marze, S.; McClements, D. J.; Ménard, O.; Recio, I.; Santos, C. N.; Singh, R. P.; Vegarud, G. E.; Wickham, M. S. J.; Weitschies, W.; Brodkorb, A. A Standardised Static in Vitro Digestion Method Suitable for Food-an International Consensus. Food Funct. 2014, 5 (6), 1113-1124. 
https://doi.org/10.1039/c3fo60702j.

(8) Humphrey, S. P.; Williamson, R. T. A Review of Saliva: Normal Composition, Flow, and Function. J. Prosthet. Dent. 2001, 85 (2), 162-169. https://doi.org/10.1067/mpr.2001.113778.

(9) Drago, S. R.; Panouillé, M.; Saint-Eve, A.; Neyraud, E.; Feron, G.; Souchon, I. Relationships between Saliva and Food Bolus Properties from Model Dairy Products. Food Hydrocoll. 2011, 25 (4), 659-667. https://doi.org/10.1016/j.foodhyd.2010.07.024.

(10) Bornhorst, G. M.; Paul Singh, R. Gastric Digestion In Vivo and In Vitro: How the Structural Aspects of Food Influence the Digestion Process. Annu. Rev. Food Sci. Technol. 2014, 5 (1), 111-132. https://doi.org/10.1146/annurev-food-030713-092346.

(11) Liu, W.; Fu, D.; Zhang, X.; Chai, J.; Tian, S.; Han, J. Development and Validation of a New Artificial Gastric Digestive System. Food Res. Int. 2019, 122 ,

183-190. https://doi.org/10.1016/j.foodres.2019.04.015.

(12) O'Connor, A.; O'Moráin, C. Digestive Function of the Stomach. Dig. Dis. 2014, 32 (3), 186-191. https://doi.org/10.1159/000357848.

(13) Tran Do, D. H.; Kong, F. Texture Changes and Protein Hydrolysis in Different Cheeses under Simulated Gastric Environment. LWT 2018, 93, 197-203. https://doi.org/10.1016/j.lwt.2018.03.028.

(14) Shani-Levi, C.; Alvito, P.; Andrés, A.; Assunção, R.; Barberá, R.; Blanquet-Diot, S.; Bourlieu, C.; Brodkorb, A.; Cilla, A.; Deglaire, A.; Denis, S.; Dupont, D.; Heredia, A.; Karakaya, S.; Giosafatto, C. V. L.; Mariniello, L.; Martins, C.; Ménard, O.; El, S. N.; Vegarud, G. E.; Ulleberg, E.; Lesmes, U. Extending in Vitro Digestion Models to Specific Human Populations: Perspectives, Practical Tools and BioRelevant Information. Trends in Food Science and Technology. Elsevier 2017, pp 52-63. https://doi.org/10.1016/j.tifs.2016.10.017.

(15) Kopf-Bolanz, K. A.; Schwander, F.; Gijs, M.; Vergères, G.; Portmann, 
R.; Egger, L. Validation of an In Vitro Digestive System for Studying Macronutrient Decomposition in Humans. J. Nutr. 2012, 142 (2), 245-250. https://doi.org/10.3945/jn.111.148635.

(16) Sicard, J.; Mirade, P. S.; Portanguen, S.; Clerjon, S.; Kondjoyan, A. Simulation of the Gastric Digestion of Proteins of Meat Bolus Using a Reaction-Diffusion Model. Food Funct. 2018, 9 (12), 6455-6469. https://doi.org/10.1039/c8fo01120f.

(17) Sams, L.; Paume, J.; Giallo, J.; Carrière, F. Relevant PH and Lipase for in Vitro Models of Gastric Digestion. Food and Function. Royal Society of Chemistry January 1, 2016, pp 30-45. https://doi.org/10.1039/c5fo00930h.

(18) Bax, M.-L.; Aubry, L.; Ferreira, C.; Daudin, J.-D.; Gatellier, P.; Re, D.; Sante, ronique. Cooking Temperature Is a Key Determinant of in Vitro Meat Protein Digestion Rate: Investigation of Underlying Mechanisms. 2012. https://doi.org/10.1021/jf205280y.

(19) Tang, J. Specificity of Pepsin and Its Dependence on a Possible "hydrophobic Binding Site" [16]. Nature. Nature Publishing Group 1963, pp 1094-1095. https://doi.org/10.1038/1991094a0.

(20) Kananen, A.; Savolainen, J.; Mäkinen, J.; Perttilä, U.; Myllykoski, L.; Pihlanto-Leppälä, A. Influence of Chemical Modification of Whey Protein Conformation on Hydrolysis with Pepsin and Trypsin. Int. Dairy J. 2000, 10 (10), 691-697. https://doi.org/10.1016/S09586946(00)00094-7.

(21) Freeman, D. E. Small Intestine. Equine Surg. 2006, 4, 416-453.

(22) Gray, V. A.; Cole, E.; Riva Toma, J. M. D.; Ghidorsi, L.; Guo, J. H.; Han, J. H.; Han, F.; Hosty, C. T.; Kochling, J. D.; Kraemer, J.; Langdon, T.; Leinbach, S. R.; Martin, G. P.; Meyerhoffer, S. M.; Morton, R. C.; Raghavan, K. S.; Shneyvas, E.; Suggett, J. A.; Tindal, S.; Vudathala, M.; Wang, H.; Anand, O.; Gao, Z.; Shah, R.; Xia, L.; Fotso, J.; Hussain, M. A.; Schmidt, V. N.; Ghosh, T.; Davydova, N.; Brown, W. E.; Fringer, J. 
M.; Stipple, E. S.; Eranui, T.; Marques, M. R. C. Use of Enzymes in the Dissolution Testing of Gelatin Capsules and Gelatin-Coated Tablets Revisions to Dissolution < $711>$ and Disintegration and Dissolution of Dietary Supplements $<2040>$. Pharmacopeial Forum 2014, 40 (6), 6-20.

(23) Feunteun, S. Le; Al-Razaz, A.; Dekker, M.; George, E.; Laroche, B.; van Aken, G. Physiologically Based Modeling of Food Digestion and Intestinal Microbiota: State of the Art and Future Challenges. An INFOGEST Review. Annu. Rev. Food Sci. Technol. 2021, 12 (1). https://doi.org/10.1146/annurev-food-070620-124140.

(24) Aburub, A.; Fischer, M.; Camilleri, M.; Semler, J. R.; Fadda, H. M. Comparison of $\mathrm{PH}$ and Motility of the Small Intestine of Healthy Subjects and Patients with Symptomatic Constipation Using the Wireless Motility Capsule. Int. J. Pharm. 2018, 544 (1), 158-164. https://doi.org/10.1016/j.ijpharm.2018.04.031.

(25) Rehfeld, J. F. Cholecystokinin. Best Pract. Res. Clin. Endocrinol. Metab. 2004, 18 (4), 569-586. https://doi.org/10.1016/j.beem.2004.07.002.

(26) Maldonado-Valderrama, J.; Wilde, P.; Maclerzanka, A.; MacKie, A. The Role of Bile Salts in Digestion. In Advances in Colloid and Interface Science; Elsevier, 2011; Vol. 165, pp 36-46. https://doi.org/10.1016/j.cis.2010.12.002.

(27) Hoover, R.; Zhou, Y. In Vitro and in Vivo Hydrolysis of Legume Starches by $\alpha$-Amylase and Resistant Starch Formation in Legumes A Review. Carbohydrate Polymers. December 1, 2003, pp 401-417. https://doi.org/10.1016/S0144-8617(03)00180-2.

(28) Feher, J. Digestion and Absorption of the Macronutrients. In Quantitative Human Physiology; Elsevier, 2012; pp 731-743. https://doi.org/10.1016/b978-0-12-382163-8.00081-5.

(29) Macfarlane, G. T.; Macfarlane, S. Fermentation in the Human Large 
Intestine: Its Physiologic Consequences and the Potential Contribution of Prebiotics. In Journal of Clinical Gastroenterology; 2011; Vol. 45, pp S120-S127. https://doi.org/10.1097/MCG.0b013e31822fecfe.

(30) Odamaki, T.; Kato, K.; Sugahara, H.; Hashikura, N.; Takahashi, S.; Xiao, J. Z.; Abe, F.; Osawa, R. Age-Related Changes in Gut Microbiota Composition from Newborn to Centenarian: A Cross-Sectional Study. BMC Microbiol. 2016, 16 (1), 90. https://doi.org/10.1186/s12866016-0708-5.

(31) O'Toole, P. W.; Claesson, M. J. Gut Microbiota: Changes throughout the Lifespan from Infancy to Elderly. International Dairy Journal. Elsevier April 1, 2010, pp 281-291. https://doi.org/10.1016/j.idairyj.2009.11.010.

(32) D'Argenio, G.; Mazzacca, G. Short-Chain Fatty Acid in the Human Colon; Springer, Boston, MA, 1999; pp 149-158. https://doi.org/10.1007/978-1-4757-3230-6_13.

(33) Mortensen, P. B.; Clausen, M. R. Short-Chain Fatty Acids in the Human Colon: Relation to Gastrointestinal Health and Disease. Scandinavian Journal of Gastroenterology, Supplement. Taylor \& Francis 1996, pp 132-148. https://doi.org/10.3109/00365529609094568.

(34) Damodaran, S. Food Proteins and Their Applications; CRC Press, 2017.

(35) Phillips, L. G. Structure-Function Properties of Food Proteins; Academic Press, 2013.

(36) Zayas, J. F. Functionality of Proteins in Food; Springer science \& business media, 2012.

(37) Rinaldi, L.; Gauthier, S. F.; Britten, M.; Turgeon, S. L. Invitro Gastrointestinal Digestion of Liquid and Semi-Liquid Dairy Matrixes. LWT - Food Sci. Technol. 2014, 57 (1), 99-105. 
https://doi.org/10.1016/j.Iwt.2014.01.026.

(38) Kenmogne-Domguia, H. B.; Meynier, A.; Viau, M.; Llamas, G.; Genot, C. Gastric Conditions Control Both the Evolution of the Organization of Protein-Stabilized Emulsions and the Kinetic of Lipolysis during in Vitro Digestion. Food Funct. 2012, 3 (12), 1302-1309. https://doi.org/10.1039/c2fo30031a.

(39) Karami, Z.; Akbari-adergani, B. Bioactive Food Derived Peptides: A Review on Correlation between Structure of Bioactive Peptides and Their Functional Properties. Journal of Food Science and Technology. Springer February 5, 2019, pp 535-547. https://doi.org/10.1007/s13197-018-3549-4.

(40) Carey, M. C.; Small, D. M.; Bliss, C. M. Lipid Digestion and Absorption. Annual review of physiology. 1983, pp 651-677. https://doi.org/10.1146/annurev.ph.45.030183.003251.

(41) Gerbig, S.; Takáts, Z. Analysis of Triglycerides in Food Items by Desorption Electrospray Ionization Mass Spectrometry. Rapid Commun. Mass Spectrom. 2010, 24 (15), 2186-2192. https://doi.org/10.1002/rcm.4630.

(42) Mennella, I.; Fogliano, V.; Vitaglione, P. Salivary Lipase and $\alpha-$ Amylase Activities Are Higher in Overweight than in Normal Weight Subjects: Influences on Dietary Behavior. Food Res. Int. 2014, 66, 463-468. https://doi.org/10.1016/j.foodres.2014.10.008.

(43) Levy, E.; Goldstein, R.; Freier, S.; Shafrir, E. Characterization of Gastric Lipolytic Activity. Biochim. Biophys. Acta (BBA)/Lipids Lipid Metab. 1981, 664 (2), 316-326. https://doi.org/10.1016/00052760(81)90054-0.

(44) Pafumi, Y.; Lairon, D.; De La Porte, P. L.; Juhel, C.; Storch, J.; Hamosh, M.; Armand, M. Mechanisms of Inhibition of Triacylglycerol Hydrolysis by Human Gastric Lipase. J. Biol. Chem. 2002, 277 (31), 28070-28079. https://doi.org/10.1074/jbc.M202839200. 
(45) Moghimipour, E.; Ameri, A.; Handali, S. Absorption-Enhancing Effects of Bile Salts. Molecules. MDPI AG August 1, 2015, pp 14451-14473. https://doi.org/10.3390/molecules200814451.

(46) Cambon, E.; Rodriguez, J. A.; Pina, M.; Arondel, V.; Carriere, F.; Turon, F.; Ruales, J.; Villeneuve, P. Characterization of Typo-, Regio-, and Stereo-Selectivities of Babaco Latex Lipase in Aqueous and Organic Media. Biotechnol. Lett. 2008, 30 (4), 769-774. https://doi.org/10.1007/s10529-007-9603-3.

(47) Salvia-Trujillo, L.; Verkempinck, S. H. E.; Sun, L.; Van Loey, A. M.; Grauwet, T.; Hendrickx, M. E. Lipid Digestion, Micelle Formation and Carotenoid Bioaccessibility Kinetics: Influence of Emulsion Droplet Size. Food Chem. 2017, 229, 653-662. https://doi.org/10.1016/j.foodchem.2017.02.146.

(48) Zhu, J.; Zhang, S.; Zhang, B.; Qiao, D.; Pu, H.; Liu, S.; Li, L. Structural Features and Thermal Property of Propionylated Starches with Different Amylose/Amylopectin Ratio. Int. J. Biol. Macromol. 2017, 97, 123-130. https://doi.org/10.1016/j.ijbiomac.2017.01.033.

(49) Syahariza, Z. A.; Sar, S.; Hasjim, J.; Tizzotti, M. J.; Gilbert, R. G. The Importance of Amylose and Amylopectin Fine Structures for Starch Digestibility in Cooked Rice Grains. Food Chem. 2013, 136 (2), 742749. https://doi.org/10.1016/j.foodchem.2012.08.053.

(50) Dhital, S.; Warren, F. J.; Butterworth, P. J.; Ellis, P. R.; Gidley, M. J. Mechanisms of Starch Digestion by $\alpha$-Amylase-Structural Basis for Kinetic Properties. Crit. Rev. Food Sci. Nutr. 2017, 57 (5), 875-892. https://doi.org/10.1080/10408398.2014.922043.

(51) Tagliazucchi, D.; Verzelloni, E.; Bertolini, D.; Conte, A. In Vitro BioAccessibility and Antioxidant Activity of Grape Polyphenols. Food Chem. 2010, 120 (2), 599-606. https://doi.org/10.1016/j.foodchem.2009.10.030.

(52) Juarez-Garcia, E.; Agama-Acevedo, E.; Sáyago-Ayerdi, S. G.; 
Rodríguez-Ambriz, S. L.; Bello-Pérez, L. A. Composition, Digestibility and Application in Breadmaking of Banana Flour. Plant Foods Hum. Nutr. 2006, 61 (3), 131-137. https://doi.org/10.1007/s11130-0060020-x.

(53) Nimalaratne, C.; Lopes-Lutz, D.; Schieber, A.; Wu, J. Effect of Domestic Cooking Methods on Egg Yolk Xanthophylls. J. Agric. Food Chem. 2012, 60 (51), 12547-12552. https://doi.org/10.1021/jf303828n.

(54) Asensio-Grau, A.; Peinado, I.; Heredia, A.; Andrés, A. Effect of Cooking Methods and Intestinal Conditions on Lipolysis, Proteolysis and Xanthophylls Bioaccessibility of Eggs. J. Funct. Foods 2018, 46, 579-586. https://doi.org/10.1016/j.jff.2018.05.025.

(55) Muto, T. Digestion and Absorption. Tokyo Daiichishuppan Co., Ltd 1988, 228.

(56) Pray, L. Relationships among the Brain, the Digestive System, and Eating Behavior: Workshop Summary; National Academies Press, 2015.

(57) Tomé, D. Digestibility Issues of Vegetable versus Animal Proteins: Protein and Amino Acid Requirements-Functional Aspects. Food Nutr. Bull. 2013, 34 (2), 272-274.

(58) Zahir, M.; Fogliano, V.; Capuano, E. Food Matrix and Processing Modulate: In Vitro Protein Digestibility in Soybeans. Food Funct. 2018, 9 (12), 6326-6336. https://doi.org/10.1039/c8fo01385c.

(59) Zahir, M.; Fogliano, V.; Capuano, E. Effect of Soybean Processing on Cell Wall Porosity and Protein Digestibility. In Food and Function; 2020; Vol. 11, pp 285-296. https://doi.org/10.1039/c9fo02167a.

(60) Dalmau, M. E.; Bornhorst, G. M.; Eim, V.; Rosselló, C.; Simal, S. Effects of Freezing, Freeze Drying and Convective Drying on in Vitro Gastric Digestion of Apples. Food Chem. 2017, 215, 7-16. https://doi.org/10.1016/j.foodchem.2016.07.134. 
(61) Lund, D. Effects of Heat Processing on Nutrients. In Nutritional Evaluation of Food Processing; Springer Netherlands, 1988; pp 319354. https://doi.org/10.1007/978-94-011-7030-7_12.

(62) Paz-Yépez, C.; Peinado, I.; Heredia, A.; Andrés, A. Influence of Particle Size and Intestinal Conditions on in Vitro Lipid and Protein Digestibility of Walnuts and Peanuts. Food Res. Int. 2019, 119, 951959. https://doi.org/10.1016/j.foodres.2018.11.014.

(63) Calvo-Lerma, J.; Paz-Yépez, C.; Asensio-Grau, A.; Heredia, A.; Andrés, A. Impact of Processing and Intestinal Conditions on in Vitro Digestion of Chia (Salvia Hispanica) Seeds and Derivatives. Foods 2020, 9 (3), 290. https://doi.org/10.3390/foods9030290.

(64) Asensio-Grau, A.; Calvo-Lerma, J.; Heredia, A.; Andrés, A. Enhancing the Nutritional Profile and Digestibility of Lentil Flour by Solid State Fermentation with: Pleurotus Ostreatus. Food Funct. 2020, 11 (9), 7905-7912. https://doi.org/10.1039/d0fo01527j.

(65) Espinosa-Páez, E.; Alanis-Guzmán, M. G.; Hernández-Luna, C. E.; Báez-González, J. G.; Amaya-Guerra, C. A.; Andrés-Grau, A. M. Increasing Antioxidant Activity and Protein Digestibility in Phaseolus Vulgaris and Avena Sativa by Fermentation with the Pleurotus Ostreatus Fungus. Molecules 2017, 22 (12), 2275. https://doi.org/10.3390/molecules22122275.

(66) Du, X.; Sun, Y.; Pan, D.; Wang, Y.; Ou, C.; Cao, J. Change of the Structure and the Digestibility of Myofibrillar Proteins in Nanjing DryCured Duck during Processing. J. Sci. Food Agric. 2018, 98 (8), 31403147. https://doi.org/10.1002/jsfa.8815.

(67) Calabuig-Jiménez, L.; Betoret, E.; Betoret Valls, N.; Patrignani, F.; Barrera Puigdollers, C.; Seguí Gil, L.; Lanciotti, R.; Dalla Rosa, M. High Pressures Homogenization (HPH) to Microencapsulate L. Salivarius Spp. Salivarius in Mandarin Juice. Probiotic Survival and in Vitro Digestion. J. Food Eng. 2019, 240, 43-48. 
(68) Bonnaire, L.; Sandra, S.; Helgason, T.; Decker, E. A.; Weiss, J.; McClements, D. J. Influence of Lipid Physical State on the in Vitro Digestibility of Emulsified Lipids. J. Agric. Food Chem. 2008, 56 (10), 3791-3797. https://doi.org/10.1021/jf800159e.

(69) Marze, S. Bioavailability of Nutrients and Micronutrients: Advances in Modeling and in Vitro Approaches. Annual Review of Food Science and Technology. Annual Reviews Inc. February 28, 2017, pp 35-55. https://doi.org/10.1146/annurev-food-030216-030055.

(70) Dickinson, E. Emulsion Gels: The Structuring of Soft Solids with Protein-Stabilized Oil Droplets. Food Hydrocolloids. Elsevier July 1, 2012, pp 224-241. https://doi.org/10.1016/j.foodhyd.2011.12.017.

(71) Fontes-Candia, C.; Ström, A.; Lopez-Sanchez, P.; López-Rubio, A.; Martínez-Sanz, M. Rheological and Structural Characterization of Carrageenan Emulsion Gels. Algal Res. 2020, 47, 101873. https://doi.org/10.1016/j.algal.2020.101873.

(72) Renard, C. M. G. C.; Watrelot, A. A.; Le Bourvellec, C. Interactions between Polyphenols and Polysaccharides: Mechanisms and Consequences in Food Processing and Digestion. Trends in Food Science and Technology. Elsevier Ltd February 1, 2017, pp 43-51. https://doi.org/10.1016/j.tifs.2016.10.022.

(73) Okuda, K. Discovery of Vitamin B12 in the Liver and Its Absorption Factor in the Stomach: A Historical Review. Journal of Gastroenterology and Hepatology (Australia). Blackwell Publishing April 1, 1999, pp 301-308. https://doi.org/10.1046/j.14401746.1999.01863.x.

(74) Torcello-Gómez, A.; Boudard, C.; Mackie, A. R. Calcium Alters the Interfacial Organization of Hydrolyzed Lipids during Intestinal Digestion. Langmuir 2018, $34 \quad$ (25), $\quad$ 7536-7544. https://doi.org/10.1021/acs.langmuir.8b00841.

(75) Vandenplas, Y. Lactose Intolerance. Asia Pac. J. Clin. Nutr. 2015, 24 
(Supplement).

(76) Singh, V. K.; Schwarzenberg, S. J. Pancreatic Insufficiency in Cystic Fibrosis. J. Cyst. Fibros. 2017, 16, S70-S78. https://doi.org/10.1016/j.jcf.2017.06.011.

(77) Gandarillas, M.; Hodgkinson, S. M.; Riveros, J. L.; Bas, F. Effect of Three Different Bariatric Obesity Surgery Procedures on Nutrient and Energy Digestibility Using a Swine Experimental Model. Exp. Biol. Med. 2015, $240 \quad$ (9), 1158-1164. https://doi.org/10.1177/1535370214567635.

(78) Torres, J.; Mehandru, S.; Colombel, J. F.; Peyrin-Biroulet, L. Crohn's Disease. The Lancet. Lancet Publishing Group April 29, 2017, pp 1741-1755. https://doi.org/10.1016/S0140-6736(16)31711-1.

(79) Lahner, E.; Carabotti, M.; Annibale, B. Treatment of Helicobacter Pylori Infection in Atrophic Gastritis. World Journal of Gastroenterology. Baishideng Publishing Group Co June 14, 2018, pp 2373-2380. https://doi.org/10.3748/wjg.v24.i22.2373.

(80) Peyron, M. A.; Santé-Lhoutellier, V.; François, O.; Hennequin, M. Oral Declines and Mastication Deficiencies Cause Alteration of Food Bolus Properties. Food Funct. 2018, 9 (2), 1112-1122. https://doi.org/10.1039/c7fo01628j.

(81) Lee, J. S.; Weyant, R. J.; Corby, P.; Kritchevsky, S. B.; Harris, T. B.; Rooks, R.; Rubin, S. M.; Newman, A. B. Edentulism and Nutritional Status in a Biracial Sample of Well-Functioning, Community-Dwelling Elderly: The Health, Aging, and Body Composition Study. Am. J. Clin. Nutr. 2004, 79 (2), 295-302. https://doi.org/10.1093/ajcn/79.2.295.

(82) Levi, S.; Lesmes, U. Bi-Compartmental Elderly or Adult Dynamic Digestion Models Applied to Interrogate Protein Digestibility †. 2014. https://doi.org/10.1039/c4fo00478g.

(83) Shani Levi, C.; Goldstein, N.; Portmann, R.; Lesmes, U. Emulsion and Protein Degradation in the Elderly: Qualitative Insights from a Study 
Coupling a Dynamic in Vitro Digestion Model with Proteomic Analyses. Food Hydrocoll. 2017, 69, 393-401. https://doi.org/10.1016/j.foodhyd.2017.02.017.

(84) Vellas, B.; Balas, D.; Moreau, J.; Bouisson, M.; Senegas-Balas, F.; Guidet, M.; Ribet, A. Exocrine Pancreatic Secretion in the Elderly. Int. J. Pancreatol. 1988, 3 (6), 497-502. https://doi.org/10.1007/BF02788208.

(85) Brodkorb, A.; Egger, L.; Alminger, M.; Alvito, P.; Assunção, R.; Ballance, S.; Bohn, T.; Bourlieu-Lacanal, C.; Boutrou, R.; Carrière, F.; Clemente, A.; Corredig, M.; Dupont, D.; Dufour, C.; Edwards, C.; Golding, M.; Karakaya, S.; Kirkhus, B.; Le Feunteun, S.; Lesmes, U.; Macierzanka, A.; Mackie, A. R.; Martins, C.; Marze, S.; McClements, D. J.; Ménard, O.; Minekus, M.; Portmann, R.; Santos, C. N.; Souchon, I.; Singh, R. P.; Vegarud, G. E.; Wickham, M. S. J.; Weitschies, W.; Recio, I. INFOGEST Static in Vitro Simulation of Gastrointestinal Food Digestion. Nat. Protoc. 2019, 14 (4), 991-1014. https://doi.org/10.1038/s41596-018-0119-1.

(86) Denis, S.; Sayd, T.; Georges, A.; Chambon, C.; Chalancon, S.; SantéLhoutellier, V.; Blanquet-Diot, S. Digestion of Cooked Meat Proteins Is Slightly Affected by Age as Assessed Using the Dynamic Gastrointestinal TIM Model and Mass Spectrometry. Food Funct. 2016, 7 (6), 2682-2691. https://doi.org/10.1039/c6fo00120c.

(87) O’Keeffe, M.; Kelly, M.; O'Herlihy, E.; O'Toole, P. W.; Kearney, P. M.; Timmons, S.; O'Shea, E.; Stanton, C.; Hickson, M.; Rolland, Y.; Sulmont Rossé, C.; Issanchou, S.; Maitre, I.; Stelmach-Mardas, M.; Nagel, G.; Flechtner-Mors, M.; Wolters, M.; Hebestreit, A.; De Groot, L. C. P. G. M.; van de Rest, O.; Teh, R.; Peyron, M. A.; Dardevet, D.; Papet, I.; Schindler, K.; Streicher, M.; Torbahn, G.; Kiesswetter, E.; Visser, M.; Volkert, D.; O'Connor, E. M. Potentially Modifiable Determinants of Malnutrition in Older Adults: A Systematic Review. Clinical Nutrition. Churchill Livingstone 2019, pp 2477-2498. https://doi.org/10.1016/j.clnu.2018.12.007. 
(88) Gille, D.; Bütikofer, U.; Chollet, M.; Schmid, A.; Altintzoglou, T.; Honkanen, P.; Stoffers, H.; Walther, B.; Piccinali, P. Nutrition Behavior of the Middle-Aged and Elderly: Compliance with Dietary Recommendations of the Food Pyramid. Clin. Nutr. 2016, 35 (3), 638-644. https://doi.org/10.1016/j.clnu.2015.04.002.

(89) De-la-O, A.; Jurado-Fasoli, L.; Castillo, M. J.; Gracia-Marco, L.; Gutierrez, Á.; Amaro-Gahete, F. J. Relationship between 1,25Dihydroxyvitamin $D$ and Body Composition in Middle-Aged Sedentary Adults: The FIT-AGEING Study. Nutrients 2019, 11 (11), 2567. https://doi.org/10.3390/nu11112567.

(90) Morley, J. E. Frailty and Sarcopenia: The New Geriatric Giants. Rev. Investig. Clin. 2016, 68 (2), 59-67.

(91) Tucker, K. L. High-Risk Nutrients in the Aging Population. In Handbook of Clinical Nutrition and Aging, Third Edition; Springer New York, 2015; pp 335-353. https://doi.org/10.1007/978-1-49391929-1_21.

(92) Shlisky, J.; Bloom, D. E.; Beaudreault, A. R.; Tucker, K. L.; Keller, H. H.; Freund-Levi, Y.; Fielding, R. A.; Cheng, F. W.; Jensen, G. L.; Wu, D.; Meydani, S. N. Nutritional Considerations for Healthy Aging and Reduction in Age-Related Chronic Disease. Adv. Nutr. An Int. Rev. J. 2017, 8 (1), 17.2-26. https://doi.org/10.3945/an.116.013474.

(93) Engelen, M. P. K. J.; Rutten, E. P. A.; De Castro, C. L. N.; Wouters, E. F. M.; Schols, A. M. W. J.; Deutz, N. E. P. Supplementation of Soy Protein with Branched-Chain Amino Acids Alters Protein Metabolism in Healthy Elderly and Even More in Patients with Chronic Obstructive Pulmonary Disease. Am. J. Clin. Nutr. 2007, 85 (2), 431439. https://doi.org/10.1093/ajcn/85.2.431.

(94) Capurso, A.; Crepaldi, G.; Capurso, C. Cereals. In Benefits of the Mediterranean Diet in the Elderly Patient; Springer International Publishing: Padua, Italy, 2018; pp 139-172. https://doi.org/10.1007/978-3-319-78084-9_8. 
(95) Volkert, D.; Beck, A. M.; Cederholm, T.; Cruz-Jentoft, A.; Goisser, S.; Hooper, L.; Kiesswetter, E.; Maggio, M.; Raynaud-Simon, A.; Sieber, C. C.; Sobotka, L.; Van Asselt, D.; Wirth, R.; Bischoff, S. C. ESPEN Guideline ESPEN Guideline on Clinical Nutrition and Hydration in Geriatrics. 2018. https://doi.org/10.1016/j.clnu.2018.05.024. 
2 OBJECTIVES 


\section{OBJECTIVES}

The aim of this doctoral thesis is to gain knowledge about the contribution of main digestive alterations appearing along ageing on the hydrolysis and bioaccesibility of relevant macro and micronutrients for elders' health, i.e., mainly proteins, liposoluble vitamins A and D3 and calcium mineral. Specifically, different dietary rich-protein sources (meats, milk and dairy products, egg, fish, legumes and cereals) were in vitro digested to also assess the role of some food-related factors on digestibility under elders' gastrointestinal (GI) conditions.

To reach this overall objective, the following specific objectives were stated:

1. To assess the impact of older's GI conditions at oral, gastric and intestinal level on protein digestion, but also on glycolysis and lipolysis in those food matrices with relevant content of these macronutrients, in 22 rich-protein dietary sources belonging to different food groups.

2. To evaluate the contribution of food-related factors (source, matrix structure, composition and processing) on protein digestion, but also on glycolysis and lipolysis in those food matrices with relevant content of these macronutrients, in 22 rich-protein dietary sources belonging to different food groups.

3. To address the impact of the above-mentioned factors on the bioaccessibility of relevant bioactive compounds (vitamins A, D3 and calcium) for elders' health and present in the foods under study.

4. To establish dietary recommendations addressed to elders based on the evidence of this doctoral thesis about the food matrices supplying the greatest bioaccessible fraction of macro and micronutrients under elders' GI conditions. 
3 WORKING PLAN 


\section{WORKING PLAN}

To achieve the planned objectives, the tasks were performed as follows:

1. Literature revision: establishing the background of the state of the art for setting up the needed analytical methodologies and for the discussion of the results.

a. Scientific literature related to gastrointestinal conditions of the elderly population, as well as for the healthy adults, was used to define the panorama and for understanding the digestive process that may be mimicked using static in vitro digestion models for the specific populations.

b. Scientific literature related to the dietary recommendations, especially those related to protein intake, for people over 65 years according to their specific needs for promoting a good health status.

2. Analysis of the impact of elderly gastrointestinal alterations on in vitro digestion of salmon, sardine, sea bass and hake: Proteolysis, lipolysis and bioaccessibility of calcium and vitamins.

a. In vitro digestion assays under elderly and standard healthy adult gastrointestinal conditions.

b. Analytical determinations of proteolysis and lipolysis extents, amino acidic and lipidic profiles, as well as the bioaccessibility of calcium and vitamins $A$ and D3.

3. Study of the understanding the role of food matrix on the digestibility of dairy products under elderly gastrointestinal conditions.

a. In vitro digestion assays under elderly and standard healthy adult gastrointestinal conditions. 
b. Analytical determinations of proteolysis and lipolysis extents, amino acidic and lipidic profiles, as well as the release of lactose, calcium and vitamins A and D3.

4. Evaluation of the impact of cooking preparation on in vitro digestion of eggs simulating some gastrointestinal alterations in elders.

a. In vitro digestion assays under elderly and standard healthy adult gastrointestinal conditions.

b. Analytical determinations of proteolysis and lipolysis extents, amino acidic and lipidic profiles, as well as the bioaccessibility of vitamins A and D3.

5. Study of the impact of common gastrointestinal disorders in elderly on in vitro meat protein digestibility and related properties.

a. In vitro digestion assays under elderly and standard healthy adult gastrointestinal conditions

b. Analytical determinations of total proteolysis extent, amino acidic profile, and the antioxidant and antihypertensive bioactivities of meat end-digestion products.

6. Determination of the contribution of age-related gastrointestinal alterations on legumes and cereal grains digestibility.

a. In vitro digestion assays under elderly and standard healthy adult gastrointestinal conditions

b. Analytical determinations of proteolysis and glycolysis extents, aminoacidic profile and the bioaccessibility of calcium. 
Table 1.4.1. In vitro methodology of dietary and host-related factors affecting digestion of protein-rich foods under elderly gastrointestinal disorders.

\section{Fish (Salmon, sardine, hake and sea bass)}

- Objective 1: Influence of fish type

- Objective 2: Influence of elderly gastrointestinal disorders on macronutrients digestion (proteins and lipids)

- Objective 3: Influence of elderly gastrointestinal disorders on vitamins A and D3 and calcium release

- Objective 4: Dietary recommendation according to each macro- and micronutrient

\section{Milk and dairy products (yogurt, fresh cheese and aged cheese)}

- Objective 1: Influence of matrix structure of milk and dairy products

- Objective 2: Influence of elderly gastrointestinal disorders on protein and lipid digestion

- Objective 3: Influence of elderly gastrointestinal disorders on vitamins A and D3, lactose and calcium release

- Objective 4: Dietary recommendation according to each macro- and micronutrient

Egg (Hard-boiled, poached and omelet)

- Objective 1: Impact of cooking method (hard-boiled, poached and omelet)

- Objective 2: Influence of elderly gastrointestinal disorders on protein and lipid digestion

- Objective 3: Influence of elderly gastrointestinal disorders on vitamins A and D3 release

- Objective 4: Dietary recommendation according to each macro- and micronutrient

Meats (Chicken, turkey, pork and beef)

- Objective 1: Influence of type of meat

- Objective 2: Influence of elderly gastrointestinal disorders on protein digestion

- Objective 3: Influence of elderly gastrointestinal disorders on bioactive properties (antioxidant and Angiotensin Converting Enzyme inhibitory activities of protein enddigestion products

- Objective 4: Dietary recommendation according to each macro- and micronutrient

Cereals (oats, spelt, quinoa) and legumes (chickpea, lentils, white bean, soya bean)

- Objective 1: Influence of the type of cereal/legume

- Objective 2: Influence of elderly gastrointestinal disorders on protein and starch digestion

- Objective 3: Influence of elderly gastrointestinal disorders on calcium bioaccessibility

- Objective 4: Dietary recommendation according to each macro- and micronutrient 
4 MATERIALS AND METHODS 


\section{MATERIALS AND METHODS}

\subsection{Sample preparation for digestion studies}

Twenty-two food products belonging to six different groups (fishes, milk and dairy products, egg products, meats, cereals and legumes) were selected according to their contribution to protein and relevant bioactive compounds recommendations supply for elders. Prior to digestion, foods, excepting milk and dairy products, were cooked. The detailed procedure for each food group is explained as follows:

\subsubsection{Fishes}

Four different fishes were selected for the study. On one hand, salmon and sardine were selected within the oily fish (blue fish) most consumed in Spain. On the other hand, lean fish (white fish) such as sea bass and hake are highly consumed in Spain and were also selected in this study.

Fishes were purchased the same day and from the same lot to avoid differences in fishes of the same specie due to seasonality, diet or cultivation methods, at a local store in Valencia (Spain). Fishes were bought fresh, cleaned and eviscerated and were frozen at $-20{ }^{\circ} \mathrm{C}$ until its posterior cooking and analysis. Prior the digestion and analysis, the fish were thawed at refrigeration temperature $\left(5^{\circ} \mathrm{C}\right)$ for $8 \mathrm{~h}$. Subsequently each type of fish were cooked by microwave heating (SAMSUNG brand, model GW72N) at $3.0 \pm 0.3 \mathrm{~W} / \mathrm{g}$ for $240 \mathrm{~s}$ (120 s each side) on an extended plate with a lid without additional fat. After cooking, fishes were cooled at room temperature and the greater amount of skin and bones were removed as possible.

\subsubsection{Milk and dairy products}

Four selected dairy products for this study (whole milk, natural yogurt, fresh cheese (Hacendado ${ }^{\circledR}$, Valencia, Spain) and 12-month aged cheese (Sa Madona ${ }^{\circledR}$, Menorca, Spain) were all exclusively of cow origin (100\%) and 57 
acquired in a local store of the city of Valencia (Spain). Products were purchased and kept at refrigeration temperature $\left(5^{\circ} \mathrm{C}\right)$ until its use for digestion and analysis.

\subsubsection{Egg products}

Standard eggs (Huevos Guillén ${ }^{\circledR}$, Valencia (Spain)) were purchased at local stores in Valencia (Spain). Fresh hen eggs were cooked and immediately characterized or in vitro digested ${ }^{1}$. For omelet, a white/yolk ratio of 70:30 (w:w) was mixed and stirred for 1 min before microwave cooking at 12.5 $\mathrm{W} / \mathrm{g}$ for $80 \mathrm{~s}$ without oil addition. For hard-boiled, whole eggs including shell were boiled with water covering the eggs for $10 \mathrm{~min}$ at $95 \pm 5^{\circ} \mathrm{C}$ and cooled under running tap water for $5 \mathrm{~min}$ and immediately peeled. For poached, eggs were broken and wrapped into cling-film, boiled for $4 \min \left(95 \pm 5^{\circ} \mathrm{C}\right)$ and cooled under running tap water for $5 \mathrm{~min}$. The egg white and yolks resulted from hard-boiling and poaching were separated to be added to the digestion tubes in the same white:yolk ratio as in omelet.

\subsubsection{Meats}

Raw meats (chicken breast, turkey breast, pork loin and beef entrecote) were purchased at a local store in Valencia (Spain). Samples were kept under freezing conditions until its use for digestion and analysis.

Sliced meats ( $50 \pm 0.5 \mathrm{~g}$ ) were microwave cooked in a household microwave oven (model GW72N, Samsung) at $12 \pm 1 \mathrm{~W} / \mathrm{g}$ for $120 \mathrm{~s}$ for chicken, turkey, pork and $75 \mathrm{~s}$ for beef. The cooking time was established in preliminary experiments based on obtaining a cooking point similar to that of cooked meats by measuring the internal temperature $\left(70^{\circ} \mathrm{C}\right)^{2}$. Cooked meats were tempered at room temperature and immediately in vitro digested and analyzed.

\subsubsection{Cereals and legumes}

Legumes (chickpea, pardina lentils, white beans (Hacendado ${ }^{\circledR}$, Valencia, Spain) and soya bean (Biográ ${ }^{\circledR}$, Barcelona, Spain)) and cereal/pseudocereal 
grains (whole oats, spelt (Biográ ${ }^{\circledR}$ ) and quinoa (Hacendado ${ }^{\circledR}$ ) were purchased at local stores in Valencia, Spain.

Chickpea, white beans, soya beans, oats and spelt were soaked and boiled before in vitro digestion studies. Soaking was overnight with deionized water (Barnstead Mega-Pure deionizer, Thermo-Fisher Scientific, Waltham, MA, USA) at a ratio of $1: 3(w: w)$ grain:water at $20 \pm 1{ }^{\circ} \mathrm{C}$.

Subsequently, soaked samples were boiled at $95 \pm 5^{\circ} \mathrm{C}$ with deionized water with a ratio of $1: 3$ (w:w) grain:water for $60,45,30,60$ and 25 min for soya bean, chickpea, white bean, whole spelt and whole oats, respectively. According to label specifications, lentils and quinoa do not need soaking process and were directly boiled at the same grain:water ratio for 20 and 10 min, respectively. Cooking time was determined and adjusted for each variety in preliminary analyses considering label recommendation, i.e., until legumes could be crushed with fingers and reached a moisture content of $60 \pm 6 \%$ (on a wet basis). All cooked samples were drained in a kitchen sieve for $2 \mathrm{~min}$ and kept cool at $20 \pm 2{ }^{\circ} \mathrm{C}$ until they reached this temperature. Cooked samples were then immediately used for composition analysis and in vitro digestion.

\subsection{Physico-chemical characterization of food products prior to digestion}

\subsubsection{Proximal composition analysis}

Water, protein, fat and ashes contents were determined in cooked samples (fishes, eggs, meats, legumes and cereals) and cheeses according to the official methods 934.01, 942.05, 920.39 and 960.52 of the Association of Official Analytical Chemist (AOAC, 2000) ${ }^{3}$, respectively. For dairy fluid matrices (milk and yogurt), the above methodologies were carried out, excepting for the fat analysis that followed the methodology of the International Standard ISO 1211 | IDF 001: 2010, ${ }^{4}$. These methodologies are included in Chapters 1 to 5.

59 
Furthermore, in cereals, legumes (Chapter 5) and dairy (Chapter 2), the sugars/lactose content (as glucose equivalent) was determined by the colorimetric method of dinitrosalicylic acid (DNS) ${ }^{5}$. Additionally, in cereals and legumes (Chapter 5 ) the starch content was determined according to the enzymatic and colorimetric method (DNS) suggested by Armellini et al. $(2019)^{5}$. In eggs (Chapter 3), carbohydrates were calculated by difference (100 g minus the sum of grams of water, ashes, lipids, and protein, in wet basis).

\subsubsection{Calcium content}

Moreover, calcium content in cooked (fishes, cereals and legumes, Chapters 1 and 5, respectively) and non-cooked samples (dairy products, Chapter 2) was determined. Ashes samples were used to determine total calcium content using a flame atomic absorption spectrometer (Thermo Scientific, iCE 3000 Series) and calcium was detected at $422.7 \mathrm{~nm}^{6}$.

\subsubsection{Fat-soluble vitamins}

Samples (fish, dairy and eggs, Chapters 1, 2 and 3, respectively) were subjected to saponification and extraction of vitamins A (retinol) and D3 (cholecalciferol) according to the protocol of Castaneda and Lee (2019) ${ }^{7}$. To quantify the liposoluble vitamins, a RP-HPLC (Waters e2695 Separation Module, Waters, Milford, MA, USA) with a Kinetex ${ }^{\mathrm{TM}} \mathrm{C} 18$ column $5 \mu \mathrm{m}, 100$ $\AA$ A $150 \times 4.6 \mathrm{~mm}$ (Phenomenex, Torrance, CA, USA) was used. Vitamins were detected using a photo diode array detector (Waters PDA 2996) at 265 and $325 \mathrm{~nm}$ for vitamin D3 and vitamin A, respectively. An isocratic separation was performed with $15 \%$ acetonitrile, $7 \%$ water and $78 \%$ methanol:tetrahydrofuran (90:10 v/v) during 10 min using a flow rate of 1 $\mathrm{mL} / \mathrm{min}$ and an injection volume of $20 \mu \mathrm{L}$. Retinol (99\%, $3100 \mathrm{U} / \mathrm{mg})$, and cholecalciferol $(\geq 98 \%$ ) were used as standards for vitamin A and D3, respectively. 


\subsubsection{Lipidic profile}

Additionally, samples with high-fat content (salmon, sea bass, fresh cheese, aged cheese, beef and the three types of eggs) were subjected to a cold lipid extraction to study the lipid profile using Proton Nuclear Magnetic Resonance $\left({ }^{1} \mathrm{H} \text { NMR) (Bruker, model } 400 / R\right)^{8}$. This methodology is included in Chapters 1, 2 and 3.

\subsubsection{Mechanical properties}

In meats, cooked samples (0.015 m cubes) were analyzed through a texture profile analysis (TPA) using a TA.XT (Stable Micro System Ltd., Godalming, Surrey, UK) with a $50 \mathrm{~kg}$ load cell and an SMS P/75 probe by compressing 80 $\%$. Hardness, cohesiveness, springiness, adhesiveness and chewiness were calculated based on the force-time deformation curves ${ }^{9}$. This methodology is only included in Chapter 4.

\subsection{Simulation of in vitro gastrointestinal digestion in elderly}

The most critical elderly disorders given at oral, gastric and intestinal level and affecting luminal digestion were simulating considering the studies evaluating oral behavior (chewing cycles needed to achieve boluses with smaller particle size distribution and safe to swallow according to the structure of foods) ${ }^{10}$ as well as the review published by Shani-Levi et al. (2017) in the frame of INFOGEST international network about the simulation of $\mathrm{Gl}$ conditions in specific population groups, and among them in elders.. Moreover, the standardized GI conditions of healthy adults were taken as control model ${ }^{12,13}$.

As shown in Table 4.3.2 elderly models were established to understand the contribution of oral, gastric and intestinal alterations in an accumulative way. Elderly 1 (E1, including oral alterations), Elderly 2 (E2, including oral + gastric alterations) and Elderly 3 (E3, including oral + gastric + intestinal 
alterations). In addition, the control model (C) corresponded to standard healthy adult $\mathrm{Gl}$ conditions according to Minekus et al. (2014).

Table 4.3.1. Specific oral, gastric and intestinal conditions of the four in vitro digestion models established in this study: control (C) and elderly (E1, E2 and E3) GI conditions.

\begin{tabular}{|c|c|c|c|c|}
\hline \multirow{2}{*}{$\begin{array}{l}\text { Digestive } \\
\text { stage }\end{array}$} & \multicolumn{4}{|c|}{ Model } \\
\hline & Control (C) & Elderly 1 (E1) & Elderly 2 (E2) & Elderly 3 (E3) \\
\hline Oral stage & $\begin{array}{l}5 \mathrm{~g} \text { of food } \\
\text { sample }+5 \mathrm{~g} \\
\text { human } \\
\text { salivary fluid } \\
\text { Chewing until } \\
\text { a consistency } \\
\text { like a tomato } \\
\text { or mustard } \\
\text { paste }\end{array}$ & $\begin{array}{l}50 \% \text { of } \\
\text { reduction } \\
\text { with respect } \\
\text { to Control } \\
\text { chewing }\end{array}$ & $\begin{array}{l}50 \% \text { of } \\
\text { reduction } \\
\text { with respect } \\
\text { to Control } \\
\text { chewing }\end{array}$ & $\begin{array}{l}50 \% \text { of } \\
\text { reduction } \\
\text { with respect } \\
\text { to Control } \\
\text { chewing }\end{array}$ \\
\hline \multirow{5}{*}{$\begin{array}{l}\text { Gastric } \\
\text { stage }\end{array}$} & $\mathrm{pH} 3$ & $\mathrm{pH} 3$ & pH 6 & pH 6 \\
\hline & $\begin{array}{l}\text { Pepsin } \quad(2000 \\
\mathrm{U} / \mathrm{mL})\end{array}$ & $\begin{array}{l}\text { Pepsin (2000 } \\
\mathrm{U} / \mathrm{mL})\end{array}$ & $\begin{array}{l}\text { Pepsin } \quad(1500 \\
\mathrm{U} / \mathrm{mL})\end{array}$ & $\begin{array}{l}\text { Pepsin }(1500 \\
\mathrm{U} / \mathrm{mL})\end{array}$ \\
\hline & $2 \mathrm{~h}$ & $2 \mathrm{~h}$ & $2 \mathrm{~h}$ & $2 \mathrm{~h}$ \\
\hline & $55 \mathrm{rpm}$ & $55 \mathrm{rpm}$ & $55 \mathrm{rpm}$ & $55 \mathrm{rpm}$ \\
\hline & $37^{\circ} \mathrm{C}$ & $37^{\circ} \mathrm{C}$ & $37^{\circ} \mathrm{C}$ & $37^{\circ} \mathrm{C}$ \\
\hline \multirow{6}{*}{$\begin{array}{l}\text { Intestinal } \\
\text { stage }\end{array}$} & $\mathrm{pH} 7$ & $\mathrm{pH} 7$ & $\mathrm{pH} 7$ & pH 7 \\
\hline & Bile(10mM) & Bile (10mM) & Bile (10 mM) & Bile (5 mM) \\
\hline & $\begin{array}{l}\text { + Pancreatin } \\
(100 \mathrm{U} / \mathrm{mL})\end{array}$ & $\begin{array}{l}\text { + Pancreatin } \\
(100 \mathrm{U} / \mathrm{mL})\end{array}$ & $\begin{array}{l}\text { + Pancreatin } \\
(100 \mathrm{U} / \mathrm{mL})\end{array}$ & $\begin{array}{l}\text { + Pancreatin } \\
(50 \mathrm{U} / \mathrm{mL})\end{array}$ \\
\hline & $2 \mathrm{~h}$ & $2 \mathrm{~h}$ & $2 \mathrm{~h}$ & $4 \mathrm{~h}$ \\
\hline & $55 \mathrm{rpm}$ & $55 \mathrm{rpm}$ & $55 \mathrm{rpm}$ & $55 \mathrm{rpm}$ \\
\hline & $37^{\circ} \mathrm{C}$ & $37^{\circ} \mathrm{C}$ & $37^{\circ} \mathrm{C}$ & $37^{\circ} \mathrm{C}$ \\
\hline
\end{tabular}

Adjustments included in the in vitro digestion models for elderlies, with respect to the control model (C), are highlighted in bold. E1 (alterations at oral stage); E2 (alterations at oral and gastric stages); E3 (alterations at oral, gastric and intestinal stages). 
The in vitro static digestion was performed as follows:

Oral stage: The number of mastication cycles were previously standardized. Briefly, food sample was placed in the mouth by the subject, followed to insert the food among teeth and began to chew until the bolus can be easily swallowed. The bolus was expectorated after completing the mastication just before the subject felt the need to swallow. Having thus, the swallowing threshold at the point in which can be expectorated easily can be identified ${ }^{10}$. The oral experiment has to be in vivo performed using a healthy volunteer with good dentition. The bolus characteristics are considered performed correctly if a bolus consistency similar to a tomato or mustard paste is achieved ${ }^{12}$. For the elderly, the number of chewing cycles are reduced to $50 \%$ by the same volunteer to mimic one of the most critical oral changes with the elderly, i.e., edentulism, generating a bolus with a larger particle size and more difficult to swallow (Lee et al., 2004; O'Keeffe et al., 2019). Generally, the physical characteristics of some foods define the number of chewing cycles (i.e., harder food would generally require more chewing cycles) (Chen, 2009).

Gastric stage: After the oral stage, simulated gastric fluid (SGF) adjusted to pH 3 was added to each tube containing the oral bolus (1:1 v/v). Pepsin contained in the SGF was added to reach a concentration in the gastric mixture of (2000 and $1500 \mathrm{U} / \mathrm{mL}$, respectively for control and elderly models). The $\mathrm{pH}$ of the mixtures was adjusted with $\mathrm{HCl}(1 \mathrm{~N})$ to $\mathrm{pH} 3.0 \pm 0.1$ for the control model and $6.0 \pm 0.1$ for the elderly models and samples were flipped from top to bottom at $55 \mathrm{rpm}$ for $2 \mathrm{~h}$ at $37^{\circ} \mathrm{C}$ using an Intell-Mixer RM-2 (Elmi Ltd, Riga, LV-1006, Latvia) and incubated in a chamber Selecta (JP Selecta SA, Barcelona).

Intestinal stage: After the gastric stage, the simulated intestinal fluid (SIF) was incorporated in a proportion $1: 1(\mathrm{v} / \mathrm{w})$ to each tube containing the gastric chime depending on the conditions of the models (E1, E2 or E3). SIF 63 
in the control model contains bile and pancreatin at $10 \mathrm{mM}$ and 100 trypsin units $/ \mathrm{mL}$, respectively, while for the elderly models the concentrations were reduced to $50 \%$. Samples were then being flipped from top to bottom at 55 rpm for another 2 or $4 \mathrm{~h}$, depending on the model tested, at $37^{\circ} \mathrm{C}$. $\mathrm{pH}$ was monitored during the digestion process and readjusted, if necessary, to keep it constant.

Gastric (SGS) and intestinal (SIS) digestion fluids were prepared fresh daily from stock solutions and the digestive enzymatic activity of the enzymes were tested before each experiment ${ }^{12}$. Briefly, the trypsin activity of pancreatin was measured using a continuous spectrophotometric rate determination (using Helios Zeta UV-VIS Spectrophotometer, Thermo Fisher Scientific) using p-toluene-sulfonyl-L-arginine methyl ester (TAME) as the substrate at different concentrations to obtain the rate at $247 \mathrm{~nm}$. One trypsin unit hydrolyses $1 \mu \mathrm{mol}$ of TAME/min at $25^{\circ} \mathrm{C}, \mathrm{pH} 8.1$. Likewise, the enzymatic activity of pepsin was measured at $280 \mathrm{~nm}$ using the spectrophotometric stop rate determination using different concentrations of hemoglobin as substrate. One pepsin unit will produce a $\Delta A_{280}$ of $0.001 / \mathrm{min}$ at $\mathrm{pH} 2.0$ and $37^{\circ} \mathrm{C}$, measured as TCA-soluble products.

After digestion, the $\mathrm{pH}$ of digests was adjusted to 5 and kept in an ice bath for $10 \mathrm{~min}$ to inhibit the enzymatic reactions before fraction separation and analytical determinations. The separation of the liquid fraction from the undigested remaining solids was done using a centrifuge at 4000×g (5810R, Eppendorf, Hamburg, Germany) for $5 \mathrm{~min}$ at $10{ }^{\circ} \mathrm{C}$. The supernatant was used to perform all the analytical determinations in digesta, excepting for the NMR determination where the whole of the digested tube was used. Both in vitro digestion process and analytical determinations were performed by triplicate for each food. 


\subsection{Analytical determinations in digesta}

\subsubsection{Proteins}

\subsubsection{Free amino acids (GC-MS)}

Free amino acids from protein digestion were determined using the protocol by Peinado et al. (2016) with some modifications. Briefly, the amine and carboxyl groups of the FAA contained in $100 \mu \mathrm{L}$ of the bioaccessible fraction were derivatized at room temperature in aqueous solution using the EZ-Faast amino acid kit. Derivatized samples were measured using a GC-MS (Injector 7683B series, Network GC System 6890N series, Inert Mass Selective Detector 5975 series, MSD ChemStation software) (Agilent Technologies, Palo Alto, CA, USA) using norvaline as an internal standard. A calibration of the peak area was prepared for each amino acid using the amino acids standard solution included in the kit. The extent of proteolysis was estimated considering the sum of the FAA in the bioaccessible fraction with respect to the amount of crude protein in undigested cooked food (equation 4.1).

Extent of proteolysis $(\%)=\frac{(\mathrm{g} \text { FAA in bioaccessible fraction })}{(\mathrm{g} \text { crude protein in undigested food })} \times 100$

This methodology is found in the Chapters $1-5$.

\subsubsection{Trichloroacetic acid (TCA) soluble protein}

Protein hydrolysis was evaluated by measuring the protein soluble fraction (peptides and amino acids) in trichloroacetic acid (TCA) according to Lamothe et al., (2014) ${ }^{15}$. Briefly, $500 \mu \mathrm{L}$ of $36 \%$ TCA was added to $1000 \mu \mathrm{L}$ of the bioaccessible fraction to reach a final concentration of $12 \%(w / w)$. The protein extract was prepared by mixing, incubating at 25 으 for 15 min on an Eppendorf Thermomixer Comfort (Eppendorf AG 22331, Hamburg, Germany), and centrifuging at 1200 g-force for $10 \mathrm{~min}$. The supernatant was 
collected and diluted in $50 \mathrm{mM}$ EDTA, $8 \mathrm{M}$ urea, $\mathrm{pH} 10$ buffer. The ratio supernatant: buffer ( $v: v)$ was 1:9 and 1:99 extract for gastric and intestinal samples, respectively. Soluble protein in TCA was determined by measuring absorbance at $280 \mathrm{~nm}$ against a blank prepared with appropriate digestion fluids of each digestion model. TCA soluble protein (g/100 g of crude protein in cooked meat) was calculated by means of a calibration line of bovine serum albumin (BSA) as standard and agreed to eq. 4.2 .

TCA soluble protein (\%)

$$
=\frac{(g \text { TCA soluble protein in bioccessible fraction })}{(g \text { crude protein in undigested food })} \times 100
$$

This methodology is found only in the Chapter 4.

\subsubsection{Lipids $\left({ }^{1} H-N M R\right)$}

Digesta samples were subjected to cold liquid-liquid extraction and the composition of the lipid phase, including cholesterol (only in Chapter 3), determined by ${ }^{1} \mathrm{H}-\mathrm{NMR}$ following the same procedure explained in the compositional analysis section. Thus, absorbable and non-absorbable lipid fractions, as well as the lipolysis extent, were calculated according to equations 4.3, 4.4 and 4.5:

Absorbable lipid fraction $=A G_{2-\mathrm{MG}} \%+A G_{1-M G} \%+$ FFA $\%$

Non-absorbable lipid fraction $=A G_{1,2-D G} \%+A G_{1,3-D G} \%$

Lipolysis extent $(\%)=$ Absorbable lipid fraction + Non-absorbable lipid fraction 
Where: 1,2-DG and 1,3-DG correspond to diglycerides; 1-MG and 2-MG to monoglycerides; and FFA to free fatty acids obtained in the digested samples.

This methodology can be found in the Chapters 1,2 and 3 .

\subsubsection{Carbohydrates (DNS)}

Reducing sugars released during digestion (monosaccharides) were determined in the bioaccessible fraction with a colorimetric method using dinitrosalicylic acid (DNS) after an invertase and amyloglucosidase secondary digestion ${ }^{5}$. An aliquot of $1 \mathrm{~mL}$ of the bioaccessible fraction was mixed with $4 \mathrm{~mL}$ of absolute ethanol to prepare an extract. The ethanolic extract $(50 \mu \mathrm{L})$ were added to $250 \mu \mathrm{L}$ of the enzymatic solution (1\% amyloglucosidase $+1 \%$ invertase in acetate buffer, $\mathrm{pH} \mathrm{5.2)} \mathrm{and} \mathrm{incubated} \mathrm{at}$ $37{ }^{\circ} \mathrm{C}$ for $10 \mathrm{~min}$. The DNS mixture $(750 \mu \mathrm{L}$ containing a $1: 1: 5$ mixture of 0.5 $\mathrm{mg} / \mathrm{mL}$ glucose:4 $\mathrm{M} \mathrm{NaOH}$ :DNS reagent (10 g/L of 3,5-dinitrosalicylic acid, containing $300 \mathrm{~g}$ potassium sodium tartrate and $16 \mathrm{~g} \mathrm{NaOH})$ ) were added and heated for $15 \mathrm{~min}$ at $100 \circ \mathrm{C}$. Then, $4 \mathrm{~mL}$ of cold deionized water were added and absorbances measured at $530 \mathrm{~nm}$ (using a Helios Zeta UV-VIS Spectrophotometer, Thermo Fisher Scientific). Glucose was used to obtain a calibration curve (from 0 to $10 \mathrm{mg} / \mathrm{L}$ ). The extent of glycolysis was calculated using equation 4.6:

Extent of glycolysis (\%) $=\frac{(g \text { free glucose Eq. in bioaccessible fraction })}{(g \text { starch }(\text { glucose Eq. }) \text { in undigested food })} \times 100$

This technique can be found in Chapters 2 (for quantify lactose release in dairy products) and 5 (for quantify starch hydrolysis into monosaccharides). 


\subsubsection{Micronutrients and bioactive compounds}

\subsubsection{Fat-soluble vitamins (HPLC)}

$20 \mathrm{~mL}$ of the bioaccessible fraction were subjected to saponification and extraction to determine the bioaccessibility of vitamin A and D3 following the same protocol as for total vitamin content in undigested foods. Vitamin bioaccessibility was calculated according to equation 4.7 :

Vitamin bioaccessibility $(\%)=\frac{(\mu \mathrm{g} \text { of released vitamin })}{(\mu \mathrm{g} \text { of total vitamin })} \times 100$

Where: the amount of released vitamin represents the recovered part in the bioaccessible fraction after in vitro digestion and the total amount of vitamin found in the cooked eggs before in vitro digestion.

\subsubsection{Calcium (FAAS)}

An aliquot of $4 \mathrm{~mL}$ of the bioaccessible fraction was used for free calcium determination using flame atomic absorption spectroscopy (FAAS) using the same protocol used to determine the total amount of calcium in undigested samples. The bioaccessibility of calcium was estimated using equation 4.8:

Calcium bioaccessibility $(\%)=\frac{\left(m g \mathrm{Ca}^{2+} \text { free in bioaccessible fraction }\right)}{\left(m g \mathrm{Ca}^{2+} \text { total in undigested food }\right)} \times 100$

\subsubsection{Functional properties of end-digestion products from meats}

\section{Antioxidant activity (DPPH)}

The antioxidant activity was measured in digesta according to Calvo-Lerma et al. (2020) ${ }^{16}$ with slight modifications to study the functional properties that some peptides and amino acids from the digesta can exert. Briefly, 200 and $400 \mu \mathrm{L}$ of gastric and intestinal bioaccessible fractions, respectively, were mixed with $1000 \mu \mathrm{L}$ of 80:20 methanol:deionized water and shaked at 800 rpm on an Eppendorf Thermomixer Comfort (Eppendorf AG 22331, Hamburg, Germany) for $60 \mathrm{~min}$ at 25 ㅇ․ After that, the methanolic extract 
was centrifugated at $1200 \times \mathrm{g}$ for $10 \mathrm{~min}$. Parallelly, 2,2-diphenyl-1pricrilhidayil (DPPH) solution was prepared at a concentration of $35 \mathrm{mg} / \mathrm{L}$ to reach an absorbance of $1.1 \pm 0.02$. Following, $500 \mu \mathrm{L}$ of methanolic extracts were added to $1500 \mu \mathrm{L}$ of DPPH solution and allowed to react for $60 \mathrm{~min}$ with light absence. Finally, the absorbance was measured at $515 \mathrm{~nm}$ and antioxidant activity expressed as mg Trolox eq/g TCA soluble protein with the aid of a calibration curve of Trolox. Distilled water was used as the negative control and $\mathrm{BHT}$ as a positive control ${ }^{17}$.

This methodology is found only in the Chapter 4.

\section{Angiotensin Converting Enzyme inhibitory activity (ACE ia (\%))}

ACE ia (\%) after gastric and intestinal digestion were measured according to Akillioğlu \& Karakaya (2009) ${ }^{18}$ with slight modifications. ACE reactive (25 $\mathrm{mU} / \mathrm{mL}$ ) and Hip-His-Leu (5 mM) as substrate were used for such purpose. Both solutions were prepared in $0.15 \mathrm{M}$ Tris base buffer, containing $0.3 \mathrm{M}$ $\mathrm{NaCl}$ and a $\mathrm{pH}$ adjusted at 8.3. Digested samples $(40 \mu \mathrm{L})$ and ACE reactive $(100 \mu \mathrm{L})$ were incubated at $37^{\circ} \mathrm{C}$ for $5 \mathrm{~min}$ and $100 \mu \mathrm{L}$ substrate was added. Incubation was continued for $30 \mathrm{~min}$ at the same temperature. Three controls (100 $\mu \mathrm{L} \mathrm{ACE}+40 \mu \mathrm{L}$ water; $140 \mu \mathrm{L}$ water; $40 \mu \mathrm{L}$ digesta $+100 \mu \mathrm{L}$ water) were also incubated as the digested samples. To stop the reaction, $150 \mu \mathrm{L}$ of $1 \mathrm{M} \mathrm{HCl}$ was added and mixed vigorously for $5 \mathrm{~min} .1000 \mu \mathrm{L}$ ethyl acetate was added into tubes, and tubes were vortexed and centrifuged at $1200 \mathrm{~g}$-force for $10 \mathrm{~min}$, then $750 \mu \mathrm{L}$ of the supernatant were collected and put into clean tubes. Tubes were slowly shaken at $80^{\circ} \mathrm{C}$ to evaporate ethyl acetate (approximately $20 \mathrm{~min}$ ). Solid hippuric acid remained in tubes was dissolved in $1 \mathrm{~mL}$ deionized water, and absorbance was measured at 228 $\mathrm{nm}$.

This methodology is found only in the Chapter 4. 


\subsection{Statistical analysis}

\subsubsection{Multifactorial analysis of variance (ANOVA)}

Results by group food were subjected to an analysis of variance (ANOVA) and the homogeneous groups were identified between in vitro models and type of meat by the LSD (Less Significant Difference) Fisher test. Statgraphics Centurion XVII was the software used with a confidence level of $95 \%$ ( $p$ $<0.05)$. This statistical analysis was performed in the results of the Chapters 1- 5 .

\subsubsection{Principal Components Analysis (PCA) and Pearson Correlations}

Besides, data were subjected to a Pearson correlation analysis to find the linear relationship between variables. A principal component analysis (PCA) was also performed to understand the descriptive relationship among digestion-end-parameters, the foods between groups and host $\mathrm{Gl}$ conditions (those of standard healthy adult (C) and of elderlies (E1, E2 and E3). A confidence level of $95 \%(p<0.05)$ was used in Statgraphics Centurion XVII. 


\section{References}

(1) Asensio-Grau, A.; Peinado, I.; Heredia, A.; Andrés, A. Effect of Cooking Methods and Intestinal Conditions on Lipolysis, Proteolysis and Xanthophylls Bioaccessibility of Eggs. Journal of Functional Foods 2018, 46, 579-586. https://doi.org/10.1016/j.jff.2018.05.025.

(2) Yarmand, M. S.; Homayouni, A. Effect of Microwave Cooking on the Microstructure and Quality of Meat in Goat and Lamb. Food Chemistry 2009, 112 (4), 782-785. https://doi.org/10.1016/j.foodchem.2008.06.033.

(3) AOAC. Official Methods of Análisis. Association of Official Analytical Chemists. 15th Edition. 2000.

(4) ISO; IDF. Milk - Determination of Fat Content - Gravimetric Method (Reference Method). BS EN ISO 1211:2010. 2010.

(5) Armellini, R.; Peinado, I.; Asensio-Grau, A.; Pittia, P.; Scampicchio, M.; Heredia, A.; Andres, A. In Vitro Starch Digestibility and Fate of Crocins in Pasta Enriched with Saffron Extract. Food Chemistry 2019, 283, 155-163. https://doi.org/10.1016/j.foodchem.2019.01.041.

(6) Noël, L.; Carl, M.; Vastel, C.; Guérin, T. Determination of Sodium, Potassium, Calcium and Magnesium Content in Milk Products by Flame Atomic Absorption Spectrometry (FAAS): A Joint ISO/IDF Collaborative Study. International Dairy Journal 2008, 18 (9), 899-904. https://doi.org/10.1016/j.idairyj.2008.01.003. 
(7) Castaneda, N.; Lee, Y. Microstructure of a Model Fresh Cheese and Bioaccessibility of Vitamin D3 Using in Vitro Digestion. Gels 2019, 5 (1). https://doi.org/10.3390/gels5010016.

(8) Nieva-Echevarría, B.; Goicoechea, E.; Manzanos, M. J.; Guillén, M. D. A Study by $1 \mathrm{H}$ NMR on the Influence of Some Factors Affecting Lipid in Vitro Digestion. Food Chemistry 2016, 211, 17-26. https://doi.org/10.1016/J.FOODCHEM.2016.05.021.

(9) Pematilleke, N.; Kaur, M.; Adhikari, B.; Torley, P. Influence of Meat Texture on Oral Processing and Bolus Formation. Journal of Food Engineering 2020, 283, 110038. https://doi.org/10.1016/j.jfoodeng.2020.110038.

(10) Jalabert-Malbos, M. L.; Mishellany-Dutour, A.; Woda, A.; Peyron, M. A. Particle Size Distribution in the Food Bolus after Mastication of Natural Foods. Food Quality and Preference 2007, 18

803-812. https://doi.org/10.1016/j.foodqual.2007.01.010.

(11) Shani-Levi, C.; Alvito, P.; Andrés, A.; Assunção, R.; Barberá, R.; Blanquet-Diot, S.; Bourlieu, C.; Brodkorb, A.; Cilla, A.; Deglaire, A.; Denis, S.; Dupont, D.; Heredia, A.; Karakaya, S.; Giosafatto, C. V. L.; Mariniello, L.; Martins, C.; Ménard, O.; El, S. N.; Vegarud, G. E.; Ulleberg, E.; Lesmes, U. Extending in Vitro Digestion Models to Specific Human Populations: Perspectives, Practical Tools and Bio-Relevant Information. Trends in Food Science and Technology. Elsevier February 1, 2017, pp 52-63. https://doi.org/10.1016/j.tifs.2016.10.017. 
(12) Minekus, M.; Alminger, M.; Alvito, P.; Ballance, S.; Bohn, T.; Bourlieu, C.; Carrière, F.; Boutrou, R.; Corredig, M.; Dupont, D.; Dufour, C.; Egger, L.; Golding, M.; Karakaya, S.; Kirkhus, B.; Le Feunteun, S.; Lesmes, U.; Maclerzanka, A.; MacKie, A.; Marze, S.; McClements, D. J.; Ménard, O.; Recio, I.; Santos, C. N.; Singh, R. P.; Vegarud, G. E.; Wickham, M. S. J.; Weitschies, W.; Brodkorb, A. A Standardised Static in Vitro Digestion Method Suitable for Food-an International Consensus. Food and Function 2014, 5 (6), 1113-1124. https://doi.org/10.1039/c3fo60702j.

(13) Brodkorb, A.; Egger, L.; Alminger, M.; Alvito, P.; Assunção, R.; Ballance, S.; Bohn, T.; Bourlieu-Lacanal, C.; Boutrou, R.; Carrière, F.; Clemente, A.; Corredig, M.; Dupont, D.; Dufour, C.; Edwards, C.; Golding, M.; Karakaya, S.; Kirkhus, B.; Le Feunteun, S.; Lesmes, U.; Macierzanka, A.; Mackie, A. R.; Martins, C.; Marze, S.; McClements, D. J.; Ménard, O.; Minekus, M.; Portmann, R.; Santos, C. N.; Souchon, I.; Singh, R. P.; Vegarud, G. E.; Wickham, M. S. J.; Weitschies, W.; Recio, I. INFOGEST Static in Vitro Simulation of Gastrointestinal Food Digestion. Nature Protocols 2019, 14 (4), 991-1014. https://doi.org/10.1038/s41596-018-0119-1.

(14) Peinado, I.; Koutsidis, G.; Ames, J. Production of Seafood Flavour Formulations from Enzymatic Hydrolysates of Fish ByProducts. LWT - Food Science and Technology 2016, 66, 444452. https://doi.org/10.1016/j.Iwt.2015.09.025.

(15) Lamothe, S.; Azimy, N.; Bazinet, L.; Couillard, C.; Britten, M. 
Interaction of Green Tea Polyphenols with Dairy Matrices in a Simulated Gastrointestinal Environment. 2014. https://doi.org/10.1039/c4fo00203b.

(16) Calvo-Lerma, J.; Paz-Yépez, C.; Asensio-Grau, A.; Heredia, A.; Andrés, A. Impact of Processing and Intestinal Conditions on in Vitro Digestion of Chia (Salvia Hispanica) Seeds and Derivatives. Foods 2020, 9

(3), 290. https://doi.org/10.3390/foods9030290.

(17) Mora, L.; Bolumar, T.; Heres, A.; Toldrá, F. Effect of Cooking and Simulated Gastrointestinal Digestion on the Activity of Generated Bioactive Peptides in Aged Beef Meat. Food and Function 2017, 8 (12), 4347-4355. https://doi.org/10.1039/c7fo01148b.

(18) Akillioğlu, H. G.; Karakaya, S. Effects of Heat Treatment and in Vitro Digestion on the Angiotensin Converting Enzyme Inhibitory Activity of Some Legume Species. European Food Research and Technology 2009, 229 (6), 915-921. https://doi.org/10.1007/s00217-009-1133-x. 


\section{RESULTS}


5.1 Chapter 1: Impact of elderly gastrointestinal alterations on in vitro digestion of salmon, sardine, sea bass and hake: Proteolysis, lipolysis and bioaccessibility of calcium and vitamins.

Ever Hernández-Olivas, Sara Muñoz-Pina, Ana Andrés and Ana Heredia Food Chemistry 2020, 326. https://doi.org/10.1016/j.foodchem.2020.127024 


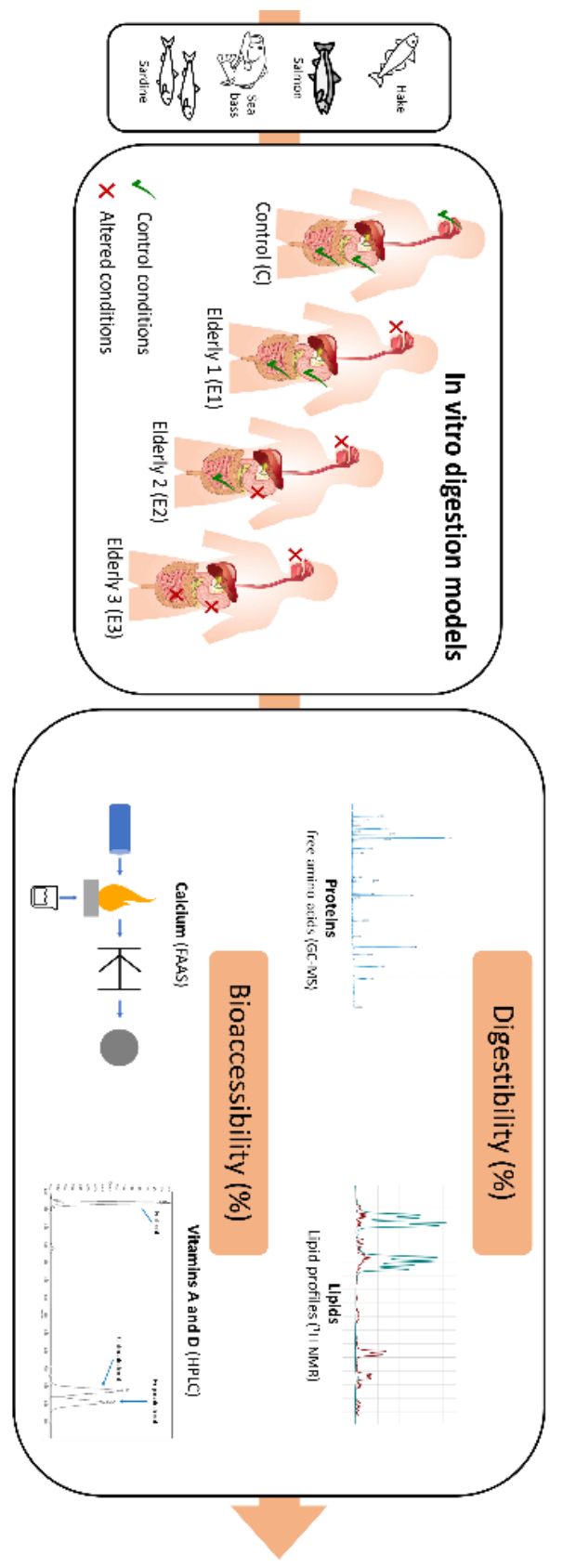




\section{Abstract}

This study aimed to analyze the effect of elderly gastrointestinal (GI) conditions on proteolysis, lipolysis and calcium and vitamins A and D3 bioaccessibility in salmon, sardine, sea bass and hake. For this purpose, cooked fishes were in vitro subjected to three elderly in vitro digestion models: E1 (oral elderly conditions), E2 (oral and gastric elderly conditions) and E3 (oral, gastric and intestinal elderly conditions)). In parallel, samples were digested under standardized GI conditions of a healthy adult as a control. Proteolysis was highly affected by elderly $\mathrm{Gl}$ alterations $(\mathrm{p}<0.05)$ (50\% of reduction compared to control), being salmon and sea bass proteolysis extent ( 40 and $33 \%$, respectively) the most affected with an important descend in leucine release. Calcium and vitamins bioaccessibility seemed to be also compromised for elders; however, the extent of the reduction highly depends on the fish type. Finally, these GI disorders did not negatively influence the bioabsorbable lipids of the fishes.

Keywords: elderly; in vitro digestion; fish; macronutrients, micronutrients 


\section{INTRODUCTION}

The world population is aging rapidly, considering that the population of "advanced age" is over 65 years old in developed countries ${ }^{1}$. It is expected that in the first five decades of the 21st century, the proportion of the world's population over 65 will double from 11 to $22 \%$. In addition, the population aged 80 or older will be the fastest growing and expected to triple by $2060^{2}$. This is why the life quality while aging is a growing global concern, identified as one of humanity's next challenges ${ }^{3}$. Life quality and the prevalence of chronic diseases depend on diet, among other factors. Nevertheless, a deterioration of certain gastrointestinal (GI) functions (i.e., reduction or alteration of enzyme secretions, luminal electrolyte composition, motility and bile secretion, among others) could lead to macronutrient maldigestion and malabsorption, among which sarcopenia or protein deficit, stands out ${ }^{4}$. Similarly, the bioaccessibility of certain micronutrients, such as vitamins and/or minerals, could also be compromised in the elderly ${ }^{5,6}$. Thus, a state of malnutrition can trigger a progressive worsening of health status, increasing the risk of falls, anemia, immune dysregulation, deterioration of cognitive status or reduction of muscle function, among others ${ }^{7}$. From a sensorial point of view, studies also indicate that elderly people experience food in a different way, due to the reduction of sensory perceptions, changes in salivation and poor oral health ${ }^{4}$. In order to minimize nutritional deficiencies in senior population, the European Society for Clinical Nutrition and Metabolism (ESPEN) recommends rich-protein foods with a daily protein intake of 1.0-1.2 g protein per kg body weight and healthy lipids to individuals over 65 years ${ }^{8}$. Preferably, this protein should be leucine-enriched essential amino acid based ${ }^{9}$. Meat and fish meet these characteristics due to their biological value of proteins, but also legumes, dairy or eggs. Thus, fish consumption for elderly is advisable due to its high nutritional quality given by the appropriate balance of amino acids and healthy unsaturated fatty acids. 
However, these recommendations consider neither that dietary proteins may be digestible differently depending on their origin, chemical properties or their interactions with other macronutrients into the food matrix (foodinherent factors) nor the influence of the different elderly Gl alterations (host-related factors) on protein digestibility. The study of the influence of food-inherent and host-related factors on protein digestibility in different food matrices might generate useful scientific knowledge for health professionals in order to provide accurate dietetic recommendations for elderly, as well as for the food industry in charge of supplying functional products addressed to elderly. In this sense, in vitro digestion models could be considered a useful tool to screen food matrices behavior along digestion under specific and controlled GI conditions of elderly, since they are faster, less expensive and laborious and with significantly lower bioethical restrictions than in vivo studies. In addition to their easy reproducibility, the possibility of easily sampling, make in vitro models very suitable for digestibility studies. Thus, host-related factors such as number of chewing cycles to achieve the physical characteristics of bolus in oral stage, $\mathrm{pH}$ and pepsin concentration in gastric stage, and transit time, bile and pancreatic enzymes concentrations in intestinal stages can be in vitro modulated to mimic luminal digestion of different population targets such as elderly people.

In this context, the objective of the present study is to evaluate, using a static in vitro digestion system based on Shani-Levi et al. (2017) ${ }^{4}$, the impact of the $\mathrm{Gl}$ alterations commonly observed in the elderly, on the luminal digestion of macronutrients (proteins and lipids) and the bioaccessibility of micronutrients (calcium and vitamins A and D3) in four different fishes (Hake, Sea bass, Salmon and Sardine).

\section{MATERIAL AND METHODS}

\section{Chemicals}


Pepsin from the porcine gastric mucosa (3200-4500 U/mg), porcine pancreatin ( $8 \times$ USP), bovine bile (dried and unfractionated), analytical grade salts (potassium chloride, potassium dihydrogen phosphate, sodium bicarbonate, magnesium chloride, ammonium carbonate, calcium chloride and potassium sulfate), boric acid (4\%), hydrochloric acid (ACS reagent grade, $37 \%$ ), sulfuric acid (ACS reagent grade, 95-97\%), sodium hydroxide (ACS reagent grade, $\geq 97.0 \%$ ), methanol (HPLC grade, $\geq 99.9 \%$ ), tetrahydrofuran (HPLC grade, $\geq 99.9 \%$ ) and retinol $(99 \%, 3100 \mathrm{U} / \mathrm{mg}$ ) and cholecalciferol ( $\geq 98 \%$ ) as vitamin A and D3 HPLC analytical standards. All reagents were obtained from Sigma-Aldrich.

Also, nitric acid (70\%), lanthanum (III) chloride heptahydrate (analytical grade) and dichloromethane (HPLC grade $>99.8 \%$ ) were purchased from Honeywell Fluka; petroleum ether $\left(40-60^{\circ} \mathrm{C}\right.$, VWR CHEMICALS), sodium chloride (PanReac AppliChem), anhydrous sodium sulfate (PanReac AppliChem), EZ-Faast amino acid kit (Phenomenex) and acetonitrile (HPLC grade, JT-Baker) were used.

Fishes (salmon, sardine, sea bass and hake) were purchased the same day and from the same lot in order to avoid differences in fishes of the same specie due to seasonality, diet or cultivation methods, at a local store in Valencia (Spain). Fishes were bought fresh, cleaned and eviscerated and were frozen at $-20 \stackrel{\circ}{ } \mathrm{C}$ until its posterior cooking and analysis.

\section{Sample Preparation}

High-consumed species in Spain were selected. Salmon and sardine are commonly considered as oily fish, and sea bass and hake as white fish. The fish were thawed at refrigeration temperature $\left(5{ }^{\circ} \mathrm{C}\right)$ for 8 hours. Subsequently, $400 \mathrm{~g}$ of each type of fish were cooked in batches of $200 \mathrm{~g}$ by microwave heating (SAMSUNG brand, model GW72N) at $600 \mathrm{~W}$ for $4 \mathrm{~min}$ ( 2 min each side) on an extended plate with a lid without additional fat. After 
cooking, fishes were cooled at room temperature and the skin and bones were removed.

\section{Compositional analysis}

After cooking, moisture, ashes, fat and protein contents were determined according to the official methods 934.01, 942.05, 920.39 and $960.52^{10}$, respectively. Moreover, calcium content in cooked samples of the four types of fish was determined. Ashed samples were used to determine the free calcium using a flame atomic absorption spectrometer (Thermo Scientific, iCE 3000 Series) and calcium was detected at $422.7 \mathrm{~nm}^{11}$.

Samples were subjected to saponification and extraction of vitamins A (retinol) and D3 (cholecalciferol) according to the protocol of Castaneda \& Lee, (2019) ${ }^{12}$. To quantify the liposoluble vitamins, aRP-HPLC (Waters e2695 Separation Module, Waters, Milford, MA, USA) with a Kinetex ${ }^{\mathrm{TM}} \mathrm{C} 18$ column $5 \mu \mathrm{m}, 100 \AA, 150 \times 4.6 \mathrm{~mm}$ (Phenomenex, Torrance, CA, USA) was used. Vitamins were detected using a photo diode array detector (Waters PDA 2996) at 265 and $325 \mathrm{~nm}$ for vitamin D3 and vitamin A, respectively. An isocratic separation was performed with $15 \%$ acetonitrile, $7 \%$ water and $78 \%$ methanol:tetrahydrofuran $(90: 10 \mathrm{v} / \mathrm{v})$ during $10 \mathrm{~min}$ using a flow rate of $1 \mathrm{~mL} / \mathrm{min}$ and an injection volume of $20 \mu \mathrm{L}$. Retinol (99\%, 3100U/mg), and cholecalciferol ( $\geq 98 \%$ ) were used as standards for vitamin A and D3, respectively.

Additionally, in salmon and sea bass (samples with the highest lipidic concentration), a cold lipid extraction was performed in order to study the lipid profile using Proton Nuclear Magnetic Resonance $\left({ }^{1} \mathrm{H} N \mathrm{NM}\right)$ (Bruker, model 400 / R), according to the published protocol by ${ }^{13}$.

\section{Static in vitro simulation of GI digestion}


Four in vitro models were defined to evaluate the contribution of the different $\mathrm{Gl}$ alterations appearing with ageing on the digestibility and bioaccessibility on nutrients present in fish meat. Concretely, the control model (C) corresponding to the standard GI conditions of a healthy adult (Minekus et al., 2014) ${ }^{14}$, and three Elderly models mimicking the accumulative alterations possibly given in elderly (Elderly 1 (oral stage altered (E1), Elderly 2 (oral and gastric stages altered (E2)) and Elderly 3 (oral, gastric and intestinal stages altered (E3)) (Table 5.1). Specific digestion conditions of elderly (>65 years old) were established according to ShaniLevi et al. (2017) ${ }^{4}$, with except of transit time of gastric and intestinal stages 15. Chewing (number of mastication cycles) was established according to Jalabert-Malbos et al. (2007) ${ }^{16}$ and to reach a bolus consistency similar to a tomato or mustard paste ${ }^{14}$. Of note, all cooked fish samples required a similar number of mastication cycles of 20 . For elderly mastication, chewing cycles number were reduced at $50 \%$, i.e. 10 , in order to achieve the most critical oral elderly scenery, generating a bolus with larger particle size and difficult to swallow ${ }^{17,18}$. Oral stage was in vivo performed by a healthy volunteer with normal dentition under informed consent. Specific conditions of each model are summarized in Table 5.1. Stock solutions of simulated digestive fluids of gastric and intestinal stages were weekly formulated according to Minekus et al. (2014) ${ }^{14}$ and stored at 4 o C. Simulated gastric and simulated intestinal fluids (SGF and SIS, respectively) were daily prepared from the respective stock solutions and taking into account the $\mathrm{pH}$ value, digestive enzymes and bile salts concentrations of each model.

In vitro digestion was performed as follows:

Oral stage: $5 \mathrm{~g}$ of cooked fish were subjected to in vivo chewing by the volunteer with normal dentition. 20 and 10 chewing cycles for healthy adult 
and elderly were performed, respectively. After chewing, food boluses were transferred to the falcon tubes to continue gastrointestinal digestion.

Gastric stage: Simulated was added to food boluses, adjusting the $\mathrm{pH}$ and the pepsin concentration, depending on the conditions to be tested (Table 5.1). Subsequently, the samples were flipped from top to bottom at $55 \mathrm{rpm}$ at $37^{\circ} \mathrm{C}$ using an Intelli-Mixer RM-2 (Elmi Ltd, Riga, LV-1006, Latvia) and incubated for $2 \mathrm{~h}$ in a chamber Selecta (JP Selecta SA, Barcelona).

Intestinal stage: After the gastric stage, SIF was incorporated in a proportion 1:1 (v/w) to each tube containing the gastric chime depending on the conditions of the models (Table 5.1.1). Samples were then being flipped from top to bottom at $55 \mathrm{rpm}$ for another 2 or $4 \mathrm{~h}$, depending on the model tested, at $37^{\circ} \mathrm{C}$. $\mathrm{pH}$ was monitored during the digestion process and readjusted if necessary to keep it constant. 
Table 5.1.1. Specific gastrointestinal conditions of the four in vitro digestion models of this study: control and eldely GI conditions.

\begin{tabular}{|c|c|c|c|c|}
\hline \multirow{2}{*}{$\begin{array}{l}\text { Digestive } \\
\text { stage }\end{array}$} & \multicolumn{4}{|c|}{ Model } \\
\hline & Control (C) & Elderly 1 (E1) & Elderly 2 (E2) & Elderly 3 (E3) \\
\hline Oral stage & $\begin{array}{l}\text { Chewing until } \\
\text { a consistency } \\
\text { like a tomato } \\
\text { or mustard } \\
\text { paste ( } 20 \\
\text { cycles) }\end{array}$ & $\begin{array}{c}50 \% \text { of } \\
\text { reduction } \\
\text { with respect } \\
\text { to Control } \\
\text { chewing (10 } \\
\text { cycles) }\end{array}$ & $\begin{array}{c}50 \% \text { of } \\
\text { reduction } \\
\text { with respect } \\
\text { to Control } \\
\text { chewing } \\
\text { (10 cycles) }\end{array}$ & $\begin{array}{c}50 \% \text { of } \\
\text { reduction } \\
\text { with respect } \\
\text { to Control } \\
\text { chewing } \\
\text { (10 cycles) }\end{array}$ \\
\hline $\begin{array}{c}\text { Gastric } \\
\text { stage }\end{array}$ & $\begin{array}{c}\text { pH } 3 \\
\text { Pepsin (2000 } \\
\text { U/mL) } \\
2 \mathrm{~h}\end{array}$ & $\begin{array}{c}\mathrm{pH} 3 \\
\text { Pepsin (2000 } \\
\mathrm{U} / \mathrm{mL}) \\
2 \mathrm{~h} \\
\end{array}$ & $\begin{array}{c}\text { pH 6 } \\
\text { Pepsin (1500 } \\
\text { U/mL) } \\
\text { 2 h }\end{array}$ & $\begin{array}{c}\text { pH } 6 \\
\text { Pepsin (1500 } \\
\text { U/mL) } \\
2 \mathrm{~h}\end{array}$ \\
\hline $\begin{array}{c}\text { Intestinal } \\
\text { stage }\end{array}$ & $\begin{array}{c}\text { pH } 7 \\
\text { Bile(10mM) } \\
+ \text { Pancreatin } \\
\text { (100 U/mL) } \\
2 \mathrm{~h}\end{array}$ & $\begin{array}{c}\text { pH } 7 \\
\text { Bile }(10 \mathrm{mM}) \\
+ \text { Pancreatin } \\
(100 \mathrm{U} / \mathrm{mL}) \\
2 \mathrm{~h}\end{array}$ & $\begin{array}{c}\mathrm{pH} 7 \\
\text { Bile }(10 \mathrm{mM}) \\
+ \text { Pancreatin } \\
(100 \mathrm{U} / \mathrm{mL}) \\
2 \mathrm{~h}\end{array}$ & $\begin{array}{c}\text { pH } 7 \\
\text { Bile (5 mM) } \\
+ \text { Pancreatin } \\
\text { (50 U/mL) } \\
4 \mathrm{~h}\end{array}$ \\
\hline
\end{tabular}

Digested samples were kept in ice bath for 10 min to lessen the enzymatic reactions before phase separation and analytical determinations. Where needed, separation of the liquid phase (referred as "micellar phase") of solid phase resulting from the digestion process was performed by centrifuging at 4000 g-force during $5 \mathrm{~min}$ at $10{ }^{\circ} \mathrm{C}$ and the supernatant was collected. 


\section{Analytical determinations in the digesta}

\section{Free amino acids profile}

Free amino acids resulting of proteins digestion were determined following the protocol published by Peinado et al. (2016) ${ }^{19}$ with some amendments. Briefly, $100 \mu \mathrm{L}$ of micellar phase were derivatized using the EZ-Faast amino acid kit and analyzed using a GC-MS (Agilent Technologies, Injector 7683B series, Network GC System 6890N series, Inert Mass Selective Detector 5975 series). The chromatograms obtained were analyzed by integrating the areas under the curve (MSDChemStation software), according to the retention times given by the kit standards and Norvaline as internal standard. The extent of proteolysis was calculated according to the equation 5.1:

Proteolysis extent (\%)

$$
=\frac{\left(g \sum \text { free amino acids in micellar phase }\right)}{(\text { initial protein })} \times 100
$$

\section{Lipid extraction and ${ }^{1} \mathrm{H} N M R$ analysis}

Digesta were subjected to a liquid-liquid extraction using dichloromethane according to Nieva-Echevarría et al. (2016) ${ }^{13}$. Subsequently, the lipid profile of the fat extracted from the digested was analyzed by Proton Nuclear Magnetic Resonance ( $\left.{ }^{1} \mathrm{H} N M R\right)$ using a BRUKER 400/R operating at 400 $\mathrm{MHz}$. The lipid profile obtained reveals the proportion of 1-monoglycerides (1-MG), 1, 2-diglycerides (1,2-DG), 1,3-diglycerides (1,3-DG), 2monoglycerides (2-MG), glycerol and fatty acids (FA) of the samples.

\section{Calcium bioaccessibility}


$4 \mathrm{~mL}$ of the micellar phase were used free calcium determination by flame atomic absorption spectroscopy following the same protocol as for total calcium determination in undigested samples. The bioaccessibility of calcium was estimated based on the equation 5.2:

Calcium bioaccessibility $(\%)=\frac{\left(m g C a^{2+} \text { free in micellar phase }\right)}{\left(m g \text { Ca }^{2+} \text { total in undigested food }\right)} \times 100$

Where the free calcium was estimated in the micellar phase of the digested and the total calcium estimated in the cooked samples before digestion.

\section{Vitamin A and D3 bioaccessibility}

The micellar phase was used to determine the bioaccessibility of vitamin A and D3 following the same protocol as for total vitamin content in undigested cooked fish. The bioaccessibility of vitamins was calculated according to equation 5.3 :

Vitamin bioaccessibility $(\%)=\frac{(\mu \mathrm{g} \text { of released vitamin })}{(\mu \mathrm{g} \text { of total vitamin })} \times 100$

Where the amount of released vitamin represents the recovered part in the micellar phase after in vitro digestion and the total amount of vitamin found in the cooked fish before in vitro digestion.

\section{Statistical analysis}

The results obtained were evaluated by means of an analysis of Variance (one-way ANOVA). In addition, Multiple Range Tests was determined by the LSD (Less Significant Difference) of Fisher test were applied to identify homogeneous groups between models and fish species. Statgraphics 
Centurion XVII software was used with a confidence level of 95\% ( $p$-value $<0.05)$.

\section{RESULTS AND DISCUSSION}

\section{Nutritional composition of the samples}

The nutritional characterization of the four cooked fish species is gathered in Table 5.1.2. In general, protein, total fat and ashes contents were similar to those reported in literature for the same food matrices ${ }^{20}$. As expected, all fishes presented high protein content, between 22.74 and $27.1 \%$, salmon being the most and hake the least. The seasonality and the type of production influence the lipid content in fishes. Of note, the total fat content of sardine (12 $\pm 1 \%$ ) was lower than expected according to scientific literature. In fact, sardines used were wildlife and caught in winter, explaining the lower fat content than those that are bred in captivity ${ }^{21}$. With regard to calcium content of the different fishes, results were consistent with those reported in the literature ${ }^{20,22}$, being the calcium content of sardine much more higher than in the other fishes, because bones were not totally removed in this fish specie remaining as part of the edible part of the sample. Vitamins A and D3 contents were also in agreement with data reported ${ }^{20}$, with exception of sardine. Thus, sea bass presents remarkable high vitamin D3 content; while salmon has the highest content in vitamin D3. Vitamins A and D3 were, however, not detected by chromatography in hake. According to these results, sea bass can be considered as the major source of vitamin A and salmon of vitamin D3 among the studied fishes. 
Table 5.1.2. Total contents of moisture, protein, fat, ashes, calcium and vitamins $A$ and $D 3$ in the four types of microwaved cooked fish (salmon, sea bass, sardine and hake).

\begin{tabular}{|c|c|c|c|c|}
\hline Nutrient & Salmon & Sea Bass & Sardine & Hake \\
\hline Moisture (g/100 g) & $58.15 \pm 0.10^{a}$ & $67.57 \pm 0.06^{b}$ & $69.20 \pm 0.15^{c}$ & $76.059 \pm 0.119^{d}$ \\
\hline Protein (g/100 g) & $27.1 \pm 0.3^{c}$ & $23.8 \pm 0.9^{a b}$ & $24.1 \pm 0.4^{b}$ & $22.74 \pm 0.09^{a}$ \\
\hline Fat (g/100 g) & $14.0 \pm 0.6^{d}$ & $6.7 \pm 0.3^{c}$ & $3.6 \pm 0.2^{b}$ & $0.34 \pm 0.05^{a}$ \\
\hline Ashes (g/100 g) & $1.33 \pm 0.07^{a}$ & $1.252 \pm 0.017^{a}$ & $2.22 \pm 0.04^{c}$ & $1.70 \pm 0.12^{b}$ \\
\hline Calcium (mg/100 g) & $25 \pm 4^{\mathrm{ab}}$ & $20.7 \pm 0.8^{a b}$ & $315 \pm 36^{c}$ & $50 \pm 11^{b}$ \\
\hline Vitamin A ( $\mu \mathrm{g} / 100 \mathrm{~g})$ & $14.6 \pm 0.8^{b}$ & $30 \pm 1^{c}$ & $9.7 \pm 0.6^{a}$ & - \\
\hline Vitamin D3 ( $\mu \mathrm{g} / 100 \mathrm{~g})$ & $14.3 \pm 0.8^{c}$ & $5.50 \pm 0.08^{a}$ & $7.6 \pm 0.9^{b}$ & - \\
\hline
\end{tabular}

Data shown are mean values from triplicates and the standard deviation.

\section{Influence of Elderly GI conditions and fish species on protein digestibility}

Figure 5.1.1A shows proteolysis extent (g of free amino acids/ $100 \mathrm{~g}$ of initial protein) at the end of intestinal stage in the different fish species (sea bass, hake, salmon and sardine) digested under standardized (C) and elderly GI conditions (E1, E2 and E3). Firstly, it can be noted that the extent of fish protein hydrolysis to amino acids under standardized $\mathrm{Gl}$ conditions (C) ranged from 50 to $70 \%$ depending of the fish species, hake proteins being less digestible than the other fish protein. Dielectric properties are dependent on polar molecules in the food matrix, and mainly of water content. An increase in water content results in higher values of dielectric constant and dielectric loss factors, and therefore a higher depth penetration of microwave energy. Regularly, low fat content is coupled with high moisture content in fishes. Therefore, it could be expected a higher microwave energy penetration, and microwave heating, into leans fishes, e.g., hake, than in oily ones. This fact has been also associated to a greater 
level of protein denaturalization than by other cooking techniques ${ }^{23}$. On the other hand, it is important to point out that the fish species were frozen since their acquisition and until their posterior cooked. Changes in protein muscle have been reported during storage because of the lipid oxidation during frozen storage. Consequently, the resulted free radicals can react with protein side chains and the carbonyl groups of the oxidized lipids, participating in more form stable protein-lipid aggregates by means of covalent bonding, and thus reducing protein digestibility ${ }^{24,25}$. Paradoxally, the effect of lipid oxidation on protein changes is most significant in lean species, such as hake, than in oily ones. In the lean fish muscle, the lipids are limited to the physiologically necessary membrane lipids, that is, they are comprised of phospholipids almost solely and a little amount of sterol esters. Hydrolysis and oxidation of these lipids may result in membrane damage and increased membrane permeability. This, in consequence, may lead to increased activity enzymes directly or indirectly, such as those responsible of oxidative reactions, involved in protein changes ${ }^{26}$.

Concerning the effect of elderly GI conditions on proteolysis, protein hydrolysis was negatively affected under any of the simulated elderly alterations (E1, E2 or E3 models). An exception to this event was found in hake for which neither oral (E1) or gastric (E2) alterations affected its protein digestibility. Thus, a reduction of proteolysis extent of $42 \pm 4,40 \pm$ $1,33 \pm 2,39 \pm 2 \%$ for hake, sea bass, salmon and sardine were registered under the worst scenario of digestion for elderly people (E3). Salmon and sea bass presented the highest protein digestibility under standard conditions and the lowest under the most affected elderly conditions (E3), being these species of higher fat content than the others.

The presence of high fat content in these fishes, and the interactions between proteins and lipids or proteins and lipid oxidation derivatives may 
occur, limiting or impeding the hydrolytic action of proteases, being this fact more relevant under suboptimal conditions ${ }^{27}$.

Therefore, the impact level of elderly $\mathrm{GI}$ conditions on protein digestibility might depend on fish matrix-inherent properties. C and E1 models differ in oral stage conditions, pretending that the breakdown of the food structure is superior in C than E1. The main objective of chewing is to reduce the particle size of ingested food particle and mix them with saliva to form a bolus with optimal characteristics to swallow. In this way, smaller particles maximize the protein surface exposure, facilitating better the accessibility of enzymes to cleavage sites ${ }^{28}$. Figure 5.1.1A shows proteolysis achieved at the end of digestion depends on the level of mastication of fish matrix, excepting in hake. The moisture content defines texture of fish meat, resulting in a softer matrix when the moisture is higher. Hake presented the greater moisture content of four cooked fishes. Beside this, hake is wellknown to be poor to keep the quality in fresh and frozen storage. The flesh is characteristically soft and, that quality attribute get worse with time life 29 .

On the other hand, the comparison between models E1 and E2 aimed to find out the contribution of gastric stage alteration to proteolysis. However, it is necessary to point out that proteolysis is estimated by means of free amino acids quantification at the end of luminal digestion, i.e., after intestinal stage. Consequently, the products of gastric proteolysis are peptides of low molecular weight that cannot be seen by the used method. Hence, the results show that an increase the $\mathrm{pH}$ to 6 and pepsin concentration reduction to $75 \%(1500 \mathrm{U} / \mathrm{mL})$ during gastric stage would not affect protein digestibility measured after luminal simulation. Thus, if a decrease of protein hydrolysis into peptides during gastric stage due to a lower pepsin activity and higher $\mathrm{pH}$ in stomach would occur, the analytical method will not register it. Moreover, taking in account that close to $\mathrm{pH} 6$ 
protein aggregates could be generated due to the isoelectric point of some proteins $(4.5<\mathrm{pH}<5.5)$ and, hindering hydrolysis could occur ${ }^{30}$.

In any case, the similar proteolysis extent achieved E1 and E2 indicates that the activity of pancreatic proteases might compensate the suboptimal conditions of the gastric stage (E2) with the hydrolysis of proteins into peptides and free amino acids. Finally, a decrease in the pancreatin concentration can lead to poor digestion and therefore to protein malabsorption causing nutritional deficiencies ${ }^{31}$. This fact is in concordance to proteolysis extent obtained under suboptimal intestinal conditions (E3) compared with optimal ones (E2). Statistical significant differences $(p<0.05)$ exist between results obtained for all cooked fishes digested under E2 and E3 $\mathrm{Gl}$ conditions, even when the transit time is longer. 

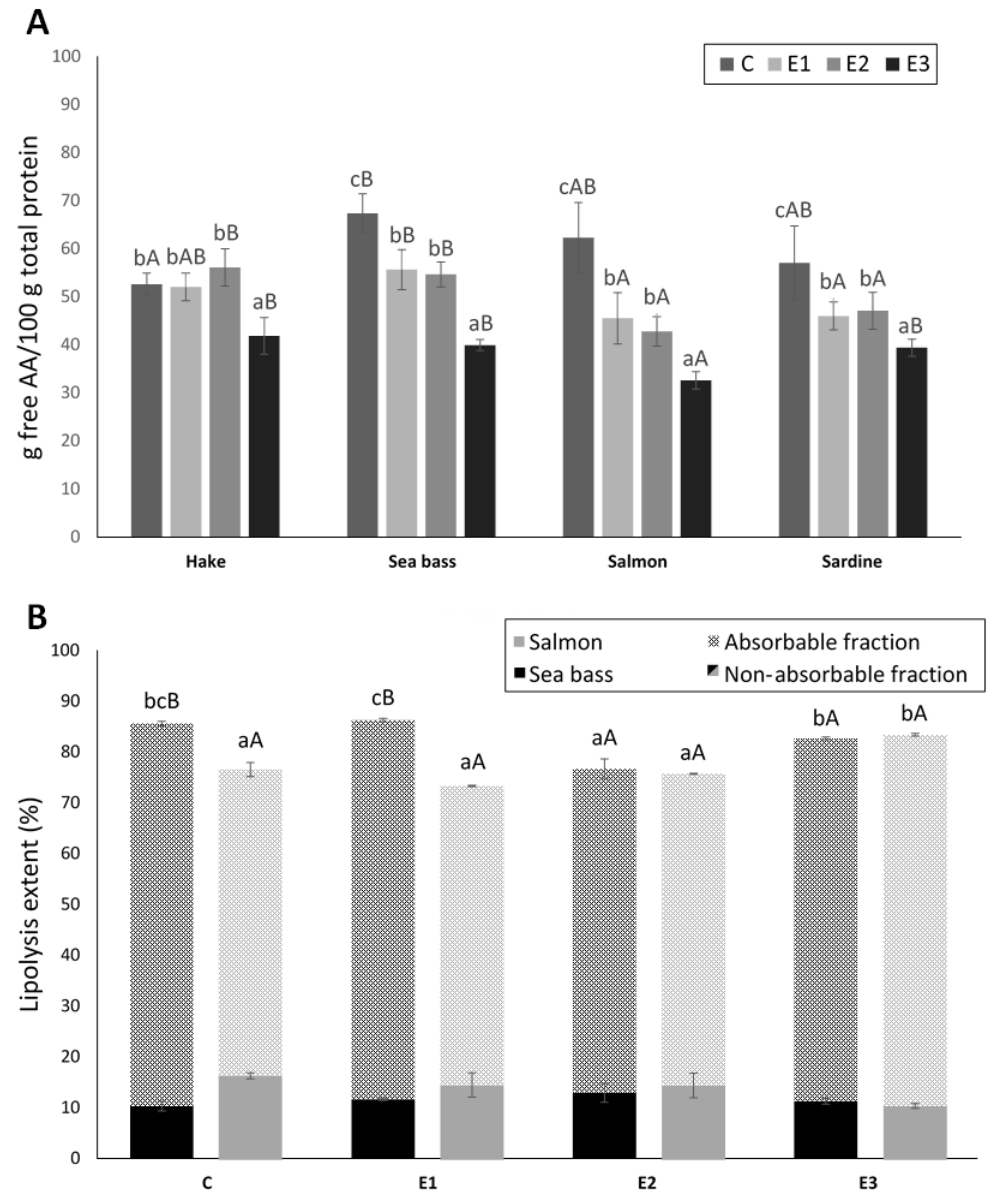

Figure 5.1.1. A) Proteolysis extent (g free amino acid (AA)/100 g total protein) of hake, sea bass, salmon and sardine under different in vitro digestion models (control (C), Elderly 1 (E1), Elderly 2 (E2), Elderly 3 (E3) models) B) Molar percentage (\%) of the absorbable and non-absorbable lipid fractions of sea bass and salmon under the different in vitro digestion models. Absorbable fraction includes to AG2-MG\% + AG1-MG\% + FA\%, nonabsorbable fraction to AG1,2-DG\% + AG1,3-DG\% and lipolysis extent 93 
represent the summarize. $a-c$ : different letters indicate significant differences of proteolysis/lipolysis extent between models. A-C: different letters indicate significant differences between foods $(p<0.05)$.

Tables 5.1.3 and 5.1.4 show free amino acids profile resulting of the proteolysis occurring under the four in vitro digestion models (C, E1, E2 and E3) and are consistent with that reported ${ }^{20,32,33}$ for the same fish species. As it can be observed, major free amino acids correspond to leucine, lysine, phenylalanine and valine, all of them essential ones. Specifically, leucine is an amino acid of interest in the elderly, since it is a key-nutrient for the stimulation of muscle protein synthesis ${ }^{31}$. However, free leucine content decreased in the digesta under altered GI conditions, and significantly $(p<0.05)$ under Elderly model $3(E 3)$. Of note, free leucine was reduced closed to $40 \%$ in salmon, sardine and sea bass digested under E3, while the release of this amino acid from hake proteins does not seem to be affected.

\section{Influence of $\mathrm{GI}$ conditions in elderly on the lipid digestibility of salmon and sea bass}

Fat digestibility was evaluated in salmon and sea bass, two species with high fat content, after in vitro digestion under control and altered conditions. This analysis was carried out through the evaluation of the spectral data obtained from ${ }^{1} \mathrm{H}$ NMR. The spectra obtained were analyzed according to Nieva-Echevarría et al. (2016) ${ }^{13}$ for the quantification of the main products derived from triglyceride hydrolysis (TG) after digestion. Table 5.1.5 gathers molar percentages of acyl groups (AG) supported on the different glyceryl backbone structures (TG, 1,2-DG, 1,3-DG, 2-MG, 1-MG) and fatty acids (FA), present in the non-digested (ND) and digesta (C, E1, E2, E3) of salmon and sea bass. As expected, almost all fat was present as TG, with $99.3 \%$ in salmon and $98.6 \%$ in sea bass before digestion. These results are consistent with those obtained by Nieva-Echevarría et al. (2015) ${ }^{34}$ in fish oil samples. After digestion under healthy standard GI conditions (C), a total lipolysis extent of 
$76 \%$ in salmon and $84.6 \%$ in sea bass occur because of the hydrolytic action of pancreatic lipase, with a conversion of TG mainly into FA (55 and 70\% for salmon and sea bass, respectively), followed by 1,2-DG, 2-MG 1,3-DG and 1MG. Considering that fat content in salmon is higher than in sea bass ( 33 and $21 \mathrm{~g}$ fat/ $\mathrm{g}$ dry matter, respectively, the amount of hydrolyzed fat at the end of the digestion is higher in salmon than in sea bass. Both FA and MG structures could be absorbed by the intestinal epithelium, after undergoing a micellization process thanks to the presence of bile salts ${ }^{35}$. Thus, the absorbable fraction was slightly superior as FA molar percentage, in sea bass than in digested salmon.

Figure 5.1.1B shows the lipolysis extent, the absorbable (bioaccessible) and non-absorbable fractions generated after in-vitro digestion. With respect to the elderly $\mathrm{Gl}$ conditions and their effect on fat digestibility, similar total lipolysis extent (around 80\%) were obtained regardless the $\mathrm{GI}$ models under both fishes were digested. Therefore, there would not be a significant $(p<0.05)$ negative effect of elderly GI conditions on fish fat digestion. Since fat digestion seems not to be affected by elderly gastrointestinal conditions, health problems like dyslipidemia could be associated to an imbalance between the recruitment of lipid substrates and the capacity of their subsequent oxidation by lipid metabolism ${ }^{36}$. This condition is well common in older individuals and is characterized by increased triglyceride levels, small high dense LDL, and a low concentration of HDL is being noted in older adults ${ }^{37}$.

Moreover, the lower pancreatic enzymes and bile concentration, and alterations in the oral and gastric phase, may not be sufficient to cause an alteration over the extent of lipolysis. Calvo-Lerma et al. (2019) ${ }^{38}$ reports that a gastric $\mathrm{pH}$ variation from 3 to 5 does not modify lipid digestibility. In fact, they found that the maximum lipolysis extent occurs at gastric $\mathrm{pH} 5$ and intestinal $\mathrm{pH}$ 7. These conditions are quite similar to those simulated in 
Table 5.1.3. Amino acids profile ( $\mathrm{mg}$ free amino acid / $100 \mathrm{~g}$ fish protein) of hake and sea bass achieved under different GI conditions (control (C), Elderly 1 (E1), Elderly 2 (E2), Elderly 3 (E3) models).

\begin{tabular}{|c|c|c|c|c|c|c|c|c|}
\hline \multirow[b]{2}{*}{ Amino acid } & \multicolumn{4}{|c|}{ Hake } & \multicolumn{4}{|c|}{ Sea bass } \\
\hline & $\mathrm{C}$ & E1 & E2 & E3 & $\mathrm{C}$ & E1 & E2 & E3 \\
\hline Alanine & $27.1 \pm 0.6^{b}$ & $26 \pm 2^{b}$ & $28 \pm 1^{b}$ & $18.9 \pm 0.8^{a}$ & $37 \pm 3^{c}$ & $28 \pm 1^{b}$ & $28 \pm 1^{b}$ & $20 \pm 2^{a}$ \\
\hline Glycine & $8 \pm 1^{\mathrm{ab}}$ & $9 \pm 2^{b}$ & $8.1 \pm 0.4^{\mathrm{ab}}$ & $4 \pm 1^{\mathrm{a}}$ & $18 \pm 2^{c}$ & $13 \pm 1^{b}$ & $11.9 \pm 0.7^{b}$ & $8 \pm 1^{\mathrm{a}}$ \\
\hline Valine & $39 \pm 1^{b}$ & $40.0 \pm 0.4^{b}$ & $45.2 \pm 0.9^{c}$ & $35 \pm 1^{a}$ & $51 \pm 3^{c}$ & $42 \pm 2^{b}$ & $41.1 \pm 0.8^{b}$ & $33.6 \pm 0.4^{a}$ \\
\hline Leucine & $78 \pm 4^{b}$ & $78 \pm 4^{b}$ & $88 \pm 2^{c}$ & $70 \pm 3^{a}$ & $105 \pm 7^{c}$ & $81 \pm 5^{b}$ & $76 \pm 1^{b}$ & $63.7 \pm 0.3^{a}$ \\
\hline Isoleucine & $29 \pm 1^{a}$ & $29 \pm 1^{a}$ & $34.6 \pm 0.4^{b}$ & $27 \pm 1^{a}$ & $37 \pm 2^{b}$ & $32 \pm 3^{a}$ & $31.5 \pm 0.8^{a}$ & $27.29 \pm 0.09^{a}$ \\
\hline Threonine & $21.0 \pm 0.9^{b}$ & $20.5 \pm 0.5^{b}$ & $24.0 \pm 0.6^{c}$ & $16.6 \pm 0.5^{a}$ & $27 \pm 1^{b}$ & $20.9 \pm 0.7^{a}$ & $21.9 \pm 0.4^{a}$ & \\
\hline Serine & $18.2 \pm 0.4^{b}$ & $16.6 \pm 0.5^{b}$ & $18 \pm 2^{b}$ & $10.0 \pm 0.6^{a}$ & $20.3 \pm 0.8^{c}$ & $17.6 \pm 0.6^{b}$ & $17.9 \pm 0.9^{b}$ & $9.7 \pm 0.2^{\mathrm{a}}$ \\
\hline Proline & $4.7 \pm 0.1^{b}$ & $5.9 \pm 0.4^{c}$ & $5.5 \pm 0.2^{b c}$ & $2.8 \pm 0.3^{a}$ & $7.3 \pm 0.4^{c}$ & $4.7 \pm 0.7^{b}$ & $4.6 \pm 0.1^{b}$ & $2.61 \pm 0.12^{a}$ \\
\hline Asparagine & $14.3 \pm 0.8^{b}$ & $13.9 \pm 0.3^{b}$ & $14.4 \pm 0.5^{b}$ & $5.5 \pm 0.3^{a}$ & $14.1 \pm 0.1^{c}$ & $14.5 \pm 1.0^{\mathrm{bc}}$ & $12.8 \pm 0.7^{b}$ & $4.9 \pm 0.2^{\mathrm{a}}$ \\
\hline Aspartic acid & $14.0 \pm 0.4^{c}$ & $10.7 \pm 0.5^{b}$ & $13.8 \pm 0.5^{c}$ & $7 \pm 1^{a}$ & $16.1 \pm 0.4^{c}$ & $13 \pm 1^{b}$ & $13.3 \pm 0.9^{b}$ & $8.59 \pm 0.04^{a}$ \\
\hline Methionine & $25 \pm 1^{\mathrm{ab}}$ & $26 \pm 2^{a b}$ & $29 \pm 1^{b}$ & $22.5 \pm 0.9^{a}$ & $35 \pm 2^{b}$ & $24 \pm 2^{a}$ & $23.3 \pm 0.2^{\mathrm{a}}$ & $20.0 \pm 0.2^{a}$ \\
\hline Glutamic acid & $\begin{array}{c}21.10 \pm \\
0.10^{b}\end{array}$ & $19 \pm 2^{b}$ & $22.3 \pm 0.6^{b}$ & $14 \pm 1^{a}$ & $22 \pm 1^{c}$ & $20 \pm 1 b c$ & $19.6 \pm 1.0^{\mathrm{b}}$ & $14.19 \pm 0.02^{\mathrm{a}}$ \\
\hline Phenylalanine & $38 \pm 1^{\mathrm{ab}}$ & $39 \pm 4^{\mathrm{ab}}$ & $46 \pm 5^{b}$ & $34 \pm 2^{a}$ & $67 \pm 6^{b}$ & $45 \pm 4^{a}$ & $42 \pm 1^{a}$ & $35.9 \pm 0.5^{a}$ \\
\hline Glutamine & $44 \pm 3^{a}$ & $42.6 \pm 0.9^{a}$ & $31 \pm 9^{a b}$ & $30 \pm 3^{a}$ & $36 \pm 4^{c}$ & $41 \pm 2^{b c}$ & $42.5 \pm 1.0^{b}$ & $25 \pm 2^{a}$ \\
\hline Lysine & $83 \pm 4^{a b}$ & $76 \pm 5^{a b}$ & $73 \pm 7^{b}$ & $71 \pm 11^{a}$ & $79 \pm 3^{b}$ & $84 \pm 8^{b}$ & $81 \pm 4^{a b}$ & $65.5 \pm 0.9^{a}$ \\
\hline Histidine & $15.1 \pm 0.8^{a}$ & $16 \pm 1^{\mathrm{ab}}$ & $19.4 \pm 0.5^{b}$ & $13 \pm 1^{a}$ & $22.0 \pm 0.3^{c}$ & $19 \pm 1^{b}$ & $18.9 \pm 0.4^{b}$ & $15.49 \pm 0.19^{a}$ \\
\hline Tyrosine & $20.9 \pm 0.5^{a}$ & $24.1 \pm 0.2^{\mathrm{ab}}$ & $39 \pm 4^{b}$ & $23 \pm 6^{a}$ & $43 \pm 2^{a}$ & $29 \pm 2^{a}$ & $41 \pm 10^{a}$ & $30 \pm 2^{a}$ \\
\hline Tryptophan & $\begin{array}{c}16.70 \pm \\
0.18^{a}\end{array}$ & $18 \pm 2^{a b}$ & $22 \pm 2^{b}$ & $14 \pm 1^{a}$ & $25 \pm 2^{b}$ & $19 \pm 2^{a}$ & $18.8 \pm 0.7^{a}$ & $14.8 \pm 0.5^{a}$ \\
\hline Cystine & $8 \pm 2^{a}$ & $9.89 \pm 0.03^{a}$ & - & - & $11.8 \pm 0.4^{b}$ & $8.8 \pm 0.9^{a}$ & - & - \\
\hline
\end{tabular}

Data shown are mean values from triplicates and the standard deviation. abc Different lowercase letters indicate significant differences between models, with a significance level of $95 \%(p<0.05)$. 
Table 5.1.4. Amino acids profile (mg free amino acid / $100 \mathrm{~g}$ fish protein) and proteolysis extent of salmon and sardine achieved under different GI conditions (control (C), Elderly 1 (E1), Elderly 2 (E2), Elderly 3 (E3) models).

\begin{tabular}{|c|c|c|c|c|c|c|c|c|}
\hline \multirow[b]{2}{*}{ Amino acid } & \multicolumn{4}{|c|}{ Salmon } & \multicolumn{4}{|c|}{ Sardine } \\
\hline & $\mathrm{C}$ & E1 & E2 & E3 & C & E1 & E2 & E3 \\
\hline Alanine & $34 \pm 4^{c}$ & $22 \pm 2^{b}$ & $25 \pm 2^{b}$ & $15.8 \pm 0.8^{\mathrm{a}}$ & $31 \pm 4^{c}$ & $25 \pm 2^{b}$ & $24 \pm 4^{b}$ & $17.9 \pm 0.7^{a}$ \\
\hline Glycine & $12 \pm 1^{b}$ & $9 \pm 2^{b}$ & $8 \pm 2^{b}$ & $3.4 \pm 0.9^{a}$ & $10 \pm 2^{b}$ & $11 \pm 5^{b}$ & $9 \pm 2^{a b}$ & $3.4 \pm 0.2^{\mathrm{a}}$ \\
\hline Valine & $46 \pm 5^{c}$ & $37 \pm 4^{b}$ & $33 \pm 2^{a b}$ & $26.7 \pm 0.6^{a}$ & $46 \pm 5^{c}$ & $35.6 \pm 0.5^{b}$ & $37 \pm 2^{b}$ & $31.24 \pm 0.06^{a}$ \\
\hline Leucine & $96 \pm 12^{b}$ & $71 \pm 9^{a}$ & $69 \pm 2^{a}$ & $54 \pm 1^{\mathrm{a}}$ & $93 \pm 12^{\mathrm{c}}$ & $69.7 \pm 0.9^{a b}$ & $78.7 \pm 0.9^{b}$ & $62 \pm 2^{a}$ \\
\hline Isoleucine & $34 \pm 4^{c}$ & $25.4 \pm 0.6^{b}$ & $25 \pm 1^{\mathrm{ab}}$ & $21.1 \pm 0.5^{a}$ & $32 \pm 4^{c}$ & $26.3 \pm 0.5^{a b}$ & $28.5 \pm 0.2^{b}$ & $24.4 \pm 0.5^{a}$ \\
\hline Threonine & $25 \pm 3^{c}$ & $17 \pm 3^{b}$ & $15.1 \pm 0.3^{a b}$ & $10.9 \pm 0.7^{a}$ & $22 \pm 4^{c}$ & $17.6 \pm 0.4^{b}$ & $17 \pm 1^{\mathrm{ab}}$ & $13.6 \pm 0.7^{a}$ \\
\hline Serine & $21 \pm 4^{b}$ & $14 \pm 3^{a}$ & $11.5 \pm 0.3^{a}$ & - & $14 \pm 2^{b}$ & $13.8 \pm 0.8^{b}$ & $12 \pm 3^{b}$ & $7 \pm 0.8^{a}$ \\
\hline \multirow[t]{2}{*}{ Proline } & $10 \pm 1^{c}$ & $6.8 \pm 0.7^{b}$ & $5.33 \pm$ & $3.1 \pm 0.15^{a}$ & & & & \\
\hline & & & $0.15^{b}$ & & $6 \pm 1^{c}$ & $4.2 \pm 0.2^{b}$ & $4.69 \pm 0.03^{a}$ & - \\
\hline Asparagine & $15 \pm 2^{c}$ & $10.2 \pm 0.7^{b}$ & $6.9 \pm 0.3^{a}$ & - & $9 \pm 2^{a}$ & $11 \pm 1^{a}$ & $8 \pm 3^{a}$ & - \\
\hline Aspartic acid & $14 \pm 2^{b}$ & $11.5 \pm 0.7^{b}$ & $7.8 \pm 0.7^{a}$ & - & $12 \pm 2^{a}$ & $9.7 \pm 0.8^{a}$ & $16 \pm 8^{a}$ & $6.2 \pm 0.2^{\mathrm{a}}$ \\
\hline Methionine & $31 \pm 5^{b}$ & $20 \pm 2^{a}$ & $19 \pm 1^{a}$ & $16 \pm 1^{a}$ & $30 \pm 4^{c}$ & $19.7 \pm 0.3^{a}$ & $23.5 \pm 0.02^{b}$ & $19.2 \pm 0.7^{a}$ \\
\hline \multirow[t]{2}{*}{ Glutamic acid } & $17.6 \pm$ & $16 \pm 2^{b}$ & $17 \pm 2^{b}$ & $11.0 \pm 0.6^{a}$ & & & & \\
\hline & $0.7^{b}$ & & & & $20 \pm 2^{c}$ & $18.3 \pm 0.6^{b}$ & $20.4 \pm 0.7^{c}$ & $13.5 \pm 0.3^{a}$ \\
\hline Phenylalanine & $55 \pm 11^{b}$ & $44 \pm 8^{a}$ & $40 \pm 2^{a}$ & $32 \pm 2^{a}$ & $54 \pm 8^{c}$ & $35.8 \pm 0.9^{\mathrm{ab}}$ & $43 \pm 3^{b}$ & $32 \pm 2^{a}$ \\
\hline Glutamine & $45 \pm 6^{c}$ & $29 \pm 4^{\mathrm{ab}}$ & $33.5 \pm 0.2^{b}$ & $23 \pm 2^{a}$ & $20 \pm 5^{a}$ & $27 \pm 8^{a}$ & $34.1 \pm 0.7^{a}$ & $30 \pm 2^{a}$ \\
\hline Lysine & $72 \pm 3^{b}$ & $58 \pm 8^{a b}$ & $45 \pm 11^{a}$ & $57 \pm 6^{\mathrm{ab}}$ & $73 \pm 9^{b}$ & $72 \pm 5^{b}$ & $40 \pm 4^{a}$ & $76 \pm 5^{b}$ \\
\hline Histidine & $22 \pm 2^{c}$ & $17 \pm 2^{b}$ & $15 \pm 1^{\mathrm{ab}}$ & $12.2 \pm 0.3^{a}$ & $25 \pm 4^{b}$ & $23 \pm 1^{a}$ & $21.2 \pm 0.8^{a}$ & $21.3 \pm 0.7^{a}$ \\
\hline Tyrosine & $52 \pm 5^{c}$ & $29.7 \pm 0.3^{\mathrm{ab}}$ & $35 \pm 1^{b}$ & $25.7 \pm 0.7^{a}$ & $38 \pm 2^{b}$ & $24 \pm 1^{a}$ & $35 \pm 4^{b}$ & $23 \pm 2^{a}$ \\
\hline Tryptophan & $24 \pm 2^{c}$ & $17 \pm 2^{b}$ & $17.6 \pm 0.7^{b}$ & $12.9 \pm 0.8^{a}$ & $23 \pm 3^{c}$ & $15.8 \pm 0.1^{\mathrm{ab}}$ & $19 \pm 2^{b}$ & $13.1 \pm 0.2^{a}$ \\
\hline Cystine & $34 \pm 4^{c}$ & $22 \pm 2^{b}$ & $25 \pm 2^{b}$ & $15.8 \pm 0.8^{a}$ & $10.4 \pm 0.6$ & - & - & - \\
\hline
\end{tabular}

Data shown are mean values from triplicates and the standard deviation. abc Different lowercase letters indicate significant differences between models, with a significance level of $95 \%(p<0.05)$. 
Table 5.1.5. Molar percentages of acyl groups (AG) supported on the different glyceryl backbone structures (TG, 1,2-DG, 1,3-DG, 2-MG, 1-MG) and fatty acids (FA), present in the lipidic phase of sea bass and salmon non-digested (ND) and digested samples under different GI conditions (control (C), Elderly 1 (E1), Elderly 2 (E2), Elderly 3 (E3) models).

\begin{tabular}{|c|c|c|c|c|c|c|c|}
\hline $\begin{array}{l}\text { Cooked } \\
\text { Fish }\end{array}$ & In vitro digestion model & $\mathrm{AG}_{\mathrm{TG}} \%$ & $\mathrm{AG}_{1,2-\mathrm{DG} \%}$ & $\mathrm{AG}_{1,3-\mathrm{DG} \%}$ & $\mathrm{AG}_{2-M G} \%$ & $\mathrm{AG}_{1-\mathrm{MG}} \%$ & FA\% \\
\hline \multirow[t]{5}{*}{ Salmon } & Non-digested & $99.3 \pm 0.7$ & - & $0.43 \pm 0.19$ & - & - & $0.2 \pm 0.9$ \\
\hline & $\mathrm{C}$ & $23.9 \pm 0.5^{b}$ & $14.91 \pm 0.18^{d}$ & $1.5 \pm 0.2^{\mathrm{a}}$ & $3.495 \pm 0.004^{b}$ & $1.12 \pm 0.14^{\mathrm{ab}}$ & $55.1 \pm 0.4^{\mathrm{ab}}$ \\
\hline & E1 & $28.75 \pm 0.08^{c}$ & $13.8 \pm 0.3^{c}$ & $1.21 \pm 0.13^{a}$ & $3.6 \pm 0.15^{b}$ & $1.22 \pm 0.15^{\mathrm{ab}}$ & $53 \pm 2^{a}$ \\
\hline & E2 & $23.14 \pm 0.09^{b}$ & $12.68 \pm 0.03^{b}$ & $1.38 \pm 0.04^{a}$ & $3.53 \pm 0.19^{b}$ & $1.4 \pm 0.4^{b}$ & $57 \pm 1^{b}$ \\
\hline & E3 & $17.1 \pm 0.4^{a}$ & $9.3 \pm 0.6^{a}$ & $1.2 \pm 0.1^{a}$ & $1.8 \pm 0.1^{\mathrm{a}}$ & $0.73 \pm 0.02^{\mathrm{a}}$ & $69.79 \pm 1.16^{c}$ \\
\hline \multirow[t]{5}{*}{ Sea bass } & Non-digested & $98.7 \pm 0.9$ & - & $0.08 \pm 0.40$ & - & - & $1.24 \pm 0.5$ \\
\hline & $\mathrm{C}$ & $15.4 \pm 0.9^{a b}$ & $9.3 \pm 1.3^{a}$ & $0.95 \pm 0.09^{a}$ & $3.2 \pm 0.4^{b}$ & $0.5 \pm 0.3^{a}$ & $70.6 \pm 0.5^{b}$ \\
\hline & E1 & $14.8 \pm 0.2^{a}$ & $10.6 \pm 0.2^{\mathrm{ab}}$ & $1.02 \pm 0.05^{\mathrm{a}}$ & $3.24 \pm 0.14^{b}$ & $8 \pm 10^{a}$ & $69.7 \pm 0.3^{b}$ \\
\hline & E2 & $24.18 \pm 1.18^{c}$ & $11.8 \pm 0.3^{b}$ & $1.1 \pm 0.3^{a}$ & $3.6 \pm 0.2^{b}$ & $0.55 \pm 0.03^{a}$ & $59 \pm 2^{a}$ \\
\hline & E3 & $18.3 \pm 0.6^{b}$ & $9.6 \pm 0.2^{\mathrm{a}}$ & $1.61 \pm 0.06^{b}$ & $2.1 \pm 0.2^{\mathrm{a}}$ & $0.8 \pm 0.6^{a}$ & $67.6 \pm 0.4^{b}$ \\
\hline
\end{tabular}

Data shown are mean values from triplicates and the standard deviation. *AG: acyl groups. a-d: different letters means significant

difference between models ( $p<0.05)$. 
E2 model (gastric $\mathrm{pH} 6$ and intestinal $\mathrm{pH}$ 7). Thus, comparing E1 and E2, it could be suggested that the gastric $\mathrm{pH}$, together with the altered concentration of pepsin $(1500 \mathrm{U} / \mathrm{mL})$, only affect the lipid digestibility in sea bass but not in salmon.

Finally, and related to the intestinal alterations represented by model E3, the longer intestinal transit time with respect to control conditions $(4 \mathrm{~h}$ instead of $2 \mathrm{~h}$ ) turns out to be a favorable factor for the digestion of lipids. In fact, lipolysis extent under E3 conditions was similar in salmon, and even higher in sea bass, than under $\mathrm{C}$ conditions. The bioaccessible fraction was, however, slightly lower than under control conditions even if sea bass digested under E3 model presented the greatest percentage of FA. Differences found in fat digestibility between the two fish species at the same Gl conditions are attributed to the inherent-food characteristics (the structural matrix, the type of fat, nutrients, among others) ${ }^{39}$, being similar the ratio of monounsaturated fatty acids, polyunsaturated fatty acids and saturated fatty acids ${ }^{20,40,41}$, but the different composition (moisture and fat) defines the texture and structure and so, the degree of enzymatic breakdown.

\section{Influence of elderly GI conditions and fish species on calcium mineral, vitamins A, D2 and D3 bioaccessibility}

A reduced digestion of macronutrients, such as proteins and lipids, could be coupled to a deficient release and solubilization of micronutrients leading to a decrease of the bioabsorbable fraction. Table 5.1.6 presents the bioaccessibility (\%) of calcium, vitamin A and D3 for the four fish species digested under the different in vitro models. Vitamin D2 was not found in samples due that it is found only in vegetables ${ }^{42}$. Calcium bioaccessibility values ranged from $94 \%$ in sea bass to $20 \%$ in sardine under standard conditions of digestion (C). Despite having sardine the highest calcium content, this mineral was less bioaccessible in this fish than in others, due 
to a bone matrix non-broken by the chewing process. Within the remaining three, the protein content could have a negative effect on the calcium bioaccessibility, due to the salting-out effect that exert the free amino acids when are present in salt form with a negative or positive charge promoting less solubility of calcium species ${ }^{43}$. In the opposite, sea bass can be considered a good source of bioaccessible calcium despite its low calcium content. The results obtained in sardine agree with that published by Titchenal \& Dobbs (2007) ${ }^{44}$, which analyzed calcium bioaccessibility in canned sardines in oil and concluded that this mineral is mainly found in the fish bones, which are ingested but not entirely digested. The obtained results showed that the suboptimal intestinal conditions given in elderly (E3) lead to a statistical significant $(p<0.05)$ reduction of calcium bioaccessibility in all fishes (values from 66 to $8 \%$ in sea bass and sardines, respectively). However, alterations occurring at oral and gastric stages (E1 and E2) did not seem to affect the release and solubilization of this mineral, excepting from sardines. Diet recommendations addressed to elderly advice an increase of calcium intake, since bone density decreases with ageing, which can lead to osteopenia and, in extreme cases, osteoporosis, which is partly related to the consumption of dietary calcium. The latter is a significant health problem that contributes to disability and premature mortality among women and older men. Although genetic factors influence maximum bone mass, diet together with an active life style are clearly two of the modifiable risk factors for osteoporosis ${ }^{31}$. In addition, vitamins A and D3 bioaccessibility were analyzed as the percentage of vitamin recovered in the micellar phase after in vitro digestion compared to the amount of vitamin found in the cooked samples before digestion. As it can be observed (Table 5.1.6), vitamin A bioaccessibility ranged from 14 to $50 \%$ under control GI conditions (C); while vitamin D3 bioaccessibility did from 19 and $66 \%$ under the same $\mathrm{Gl}$ model. The differences in terms of release, solubilization and micellar incorporation of these vitamins among fish species could be attributed to the lipid content. Thus, it is found the higher the fat content 
the greater the fat-soluble vitamins bioaccessibility ${ }^{42}$. In fact, vitamins $A$ and D3 exhibited the highest bioaccessibility in salmon that has the highest fat and achieved the highest lipolysis extent.

Table 5.1.6. Micronutrients (Calcium and vitamins A and D3) bioaccessibility in sea bass, salmon, sardine and hake under different $G I$ conditions (control (C), Elderly 1 (E1), Elderly 2 (E2), Elderly 3 (E3) models).

\begin{tabular}{lcccc}
\hline & & \multicolumn{3}{c}{ Bioaccessibility (\%) } \\
\cline { 3 - 5 } Fish & In vitro digestion model & Calcium & Vitamin A & Vitamin D3 \\
\hline Sea bass & C & $94.3 \pm 13.2^{\mathrm{bB}}$ & $21 \pm 2^{\mathrm{bA}}$ & $34 \pm 3^{\mathrm{aB}}$ \\
& E1 & $81 \pm 3^{\mathrm{bC}}$ & $19.0 \pm 0.3^{\mathrm{bB}}$ & $28 \pm 1^{\mathrm{aB}}$ \\
& E2 & $99 \pm 4^{\mathrm{bD}}$ & $12.6 \pm 0.7^{\mathrm{aA}}$ & $26 \pm 5^{\mathrm{aA}}$ \\
& E3 & $66 \pm 3^{\mathrm{aC}}$ & $13 \pm 1^{\mathrm{aA}}$ & $25 \pm 1^{\mathrm{aB}}$ \\
\hline Salmon & C & $86 \pm 8^{\mathrm{bB}}$ & $48 \pm 4^{\mathrm{bB}}$ & $66 \pm 2^{\mathrm{cC}}$ \\
& E1 & $73 \pm 7^{\mathrm{abC}}$ & $48 \pm 1^{\mathrm{bC}}$ & $57 \pm 2^{\mathrm{bcC}}$ \\
& E2 & $68 \pm 7^{\mathrm{aC}}$ & $51 \pm 4^{\mathrm{bB}}$ & $50 \pm 5^{\mathrm{abB}}$ \\
& E3 & $60 \pm 4^{\mathrm{aB}}$ & $30 \pm 2^{\mathrm{aB}}$ & $42.5 \pm 0.4^{\mathrm{aC}}$ \\
\hline Sardine & C & $20.3 \pm 0.8^{\mathrm{bA}}$ & $14 \pm 2^{\mathrm{aA}}$ & $19 \pm 3^{\mathrm{bA}}$ \\
& E1 & $20 \pm 1^{\mathrm{bA}}$ & $13.2 \pm 0.5^{\mathrm{aA}}$ & $14.37 \pm 0.17^{\mathrm{abA}}$ \\
& E2 & $8 \pm 1^{\mathrm{aA}}$ & $13.3 \pm 0.2^{\mathrm{aA}}$ & $13.2 \pm 0.3^{\mathrm{baA}}$ \\
& E3 & $8 \pm 1^{\mathrm{aA}}$ & $14.0 \pm 0.4^{\mathrm{aA}}$ & $12.23 \pm 0.04^{\mathrm{aA}}$ \\
\hline Hake & C & $40 \pm 4^{\mathrm{aA}}$ & - & - \\
& E1 & $40 \pm 10^{\mathrm{aB}}$ & - & - \\
& E2 & $33.70 \pm 0.10^{\mathrm{aB}}$ & - & - \\
\hline \hline
\end{tabular}

a-c: different letters indicate significant differences between models ( $p<0.05)$. A-C: different letters indicate significant differences between foods $(p<0.05)$. Data shown are mean values from triplicates and the standard deviation.

The digestion and absorption of the fat-soluble vitamins basically follow the same path as lipids ${ }^{31}$. This behavior is shown when no statistical differences $(p<0.05)$ were found among values of bioaccessibility achieved under Elderly models of digestion (E1, E2 and E3) in sea bass and sardines. Moreover, in salmon does not occur of this way, and the vitamins bioaccessibility was strongly reduced when intestinal conditions were altered in the Elderly model (E3), even when the fat digestibility presented a contrary behavior. Liposoluble vitamins are dependent on solubilization 
by bile acids, and an alteration in bile flow results in malabsorption ${ }^{45}$. Thus, the vitamin bioaccessibility decreased when the lipid content is greater, even that lipid bioaccessibility do not show alterations. This result indicates the importance of lipid concentration, showing low vitamins bioaccessibility when the lipid content is higher.

Therefore, the elders are advised to strengthen their skeletal health by following a diet rich in nutrients with adequate amounts of protein, vitamins and minerals. This is why the consumption of salmon could be recommended to this population group, since this fish is characterized by unsaturated fatty acids along with its high calcium content that is easily assimilated, due to the parallel supply of vitamin D offered by this food, which would favor intestinal absorption of this mineral ${ }^{46}$.

\section{CONCLUSIONS}

Results from this study evidenced that elderly GI conditions differently affected fish macronutrients and micronutrients depending on fish type. Thus, proteins fish-proteolysis extent ranged from 50 and $70 \%$ under healthy gastrointestinal conditions (control), being hake proteins the least digested. Elderly GI conditions highly affected proteolysis extent with an accumulative decreasing of extent as long as alterations in digestion stages were incorporated to the in vitro simulation. Thus, a $50 \%$ of reduction was reported for salmon and sea bass when oral, gastric and intestinal stages conditions mimicked elderly ones (proteolysis extent of 40 and $33 \%$ for salmon and sea bass, respectively). To note, leucine was among the amino acids whom release was affected the most under a total digestive disorder (E3) in all type of fish.

With respect of lipolysis, elderly $\mathrm{Gl}$ alterations do not statistical significantly $(p<0.05)$ affected the absorbable and non-absorbable fractions of lipids of salmon and sea bass. In fact, the longer intestinal transit time characteristic of elderly seems to be favorable to fat digestion. Finally, calcium and 
liposoluble vitamins A and D3 release were compromised under elderly GI conditions, however the extent of reduction seems to be very dependent of the fish type.

Thus, host-individual gastrointestinal conditions together with fish matrix and its inherent characteristics, influence macronutrients digestibility and micronutrients bioaccessibility. Therefore, this study provides relevant information to understand fish digestibility under altered gastrointestinal conditions on specific population-groups as elderly and depending on fish origin. 


\section{REFERENCES}

(1) World Health Organization. Health Statistics and Information Systems. Proposed Working Definition of an Older Person in Africa for the MDS Project. 2017.

(2) Agarwal, E.; Miller, M.; Yaxley, A.; Isenring, E. Malnutrition in the Elderly: A Narrative Review. Maturitas 2013, 76 (4), 296-302. https://doi.org/10.1016/J.MATURITAS.2013.07.013.

(3) United Nations. Department of International Economic and Social Affairs. Population Division. World Population Ageing 2015 (ST/ESA/SER. A/390).

(4) Shani-Levi, C.; Alvito, P.; Andrés, A.; Assunção, R.; Barberá, R.; Blanquet-Diot, S.; Bourlieu, C.; Brodkorb, A.; Cilla, A.; Deglaire, A.; Denis, S.; Dupont, D.; Heredia, A.; Karakaya, S.; Giosafatto, C. V. L.; Mariniello, L.; Martins, C.; Ménard, O.; El, S. N.; Vegarud, G. E.; Ulleberg, E.; Lesmes, U. Extending in Vitro Digestion Models to Specific Human Populations: Perspectives, Practical Tools and BioRelevant Information. Trends in Food Science and Technology. Elsevier February 1, 2017, pp 52-63. https://doi.org/10.1016/j.tifs.2016.10.017.

(5) Rahme, M.; Sharara, S. L.; Baddoura, R.; Habib, R. H.; Halaby, G.; Arabi, A.; Singh, R. J.; Kassem, M.; Mahfoud, Z.; Hoteit, M. Impact of Calcium and Two Doses of Vitamin D on Bone Metabolism in the Elderly: A Randomized Controlled Trial. Journal of Bone and Mineral Research 2017, 32 (7), 1486-1495.

(6) Sales, M. C.; de Oliveira, L. P.; de Araújo Cabral, N. L.; de Sousa, S. E. S.; das Graças Almeida, M.; Lemos, T. M. A. M.; de Oliveira Lyra, C.; de Lima, K. C.; Sena-Evangelista, K. C. M.; Pedrosa, L. de F. C. Plasma Zinc in Institutionalized Elderly Individuals: Relation with Immune and Cardiometabolic Biomarkers. Journal of Trace Elements in Medicine and Biology 2018, 50, 615-621.

(7) Rashid, I.; Tiwari, P.; Lehl, S. S. Malnutrition among Elderly a 
Multifactorial Condition to Flourish: Evidence from a Cross-Sectional Study. Clinical Epidemiology and Global Health 2019.

(8) Volkert, D.; Beck, A. M.; Cederholm, T.; Cruz-Jentoft, A.; Goisser, S.; Hooper, L.; Kiesswetter, E.; Maggio, M.; Raynaud-Simon, A.; Sieber, C. C.; Sobotka, L.; Van Asselt, D.; Wirth, R.; Bischoff, S. C. ESPEN Guideline ESPEN Guideline on Clinical Nutrition and Hydration in Geriatrics. 2018. https://doi.org/10.1016/j.clnu.2018.05.024.

(9) Morley, J. E. Frailty and Sarcopenia: The New Geriatric Giants. Revista de investigacion clinica 2016, 68 (2), 59-67.

(10) AOAC. Official Methods of Análisis. Association of Official Analytical Chemists. 15th Edition. 2000.

(11) Noël, L.; Carl, M.; Vastel, C.; Guérin, T. Determination of Sodium, Potassium, Calcium and Magnesium Content in Milk Products by Flame Atomic Absorption Spectrometry (FAAS): A Joint ISO/IDF Collaborative Study. International Dairy Journal 2008, 18 (9), 899904. https://doi.org/10.1016/j.idairyj.2008.01.003.

(12) Castaneda, N.; Lee, Y. Microstructure of a Model Fresh Cheese and Bioaccessibility of Vitamin D3 Using in Vitro Digestion. Gels 2019, 5 (1). https://doi.org/10.3390/gels5010016.

(13) Nieva-Echevarría, B.; Goicoechea, E.; Manzanos, M. J.; Guillén, M. D. A Study by $1 \mathrm{H}$ NMR on the Influence of Some Factors Affecting Lipid in Vitro Digestion. Food Chemistry 2016, 211, 17-26. https://doi.org/10.1016/J.FOODCHEM.2016.05.021.

(14) Minekus, M.; Alminger, M.; Alvito, P.; Ballance, S.; Bohn, T.; Bourlieu, C.; Carrière, F.; Boutrou, R.; Corredig, M.; Dupont, D.; Dufour, C.; Egger, L.; Golding, M.; Karakaya, S.; Kirkhus, B.; Le Feunteun, S.; Lesmes, U.; Maclerzanka, A.; MacKie, A.; Marze, S.; McClements, D. J.; Ménard, O.; Recio, I.; Santos, C. N.; Singh, R. P.; Vegarud, G. E.; Wickham, M. S. J.; Weitschies, W.; Brodkorb, A. A Standardised Static in Vitro Digestion Method Suitable for Food-an International Consensus. Food and Function 2014, 5 (6), 1113-1124. 
https://doi.org/10.1039/c3fo60702j.

(15) Denis, S.; Sayd, T.; Georges, A.; Chambon, C.; Chalancon, S.; SantéLhoutellier, V.; Blanquet-Diot, S. Digestion of Cooked Meat Proteins Is Slightly Affected by Age as Assessed Using the Dynamic Gastrointestinal TIM Model and Mass Spectrometry. Food and Function 2016, 7

(6),

2682-2691. https://doi.org/10.1039/c6fo00120c.

(16) Jalabert-Malbos, M. L.; Mishellany-Dutour, A.; Woda, A.; Peyron, M. A. Particle Size Distribution in the Food Bolus after Mastication of Natural Foods. Food Quality and Preference 2007, 18 (5), 803-812. https://doi.org/10.1016/j.foodqual.2007.01.010.

(17) Lee, J. S.; Weyant, R. J.; Corby, P.; Kritchevsky, S. B.; Harris, T. B.; Rooks, R.; Rubin, S. M.; Newman, A. B. Edentulism and Nutritional Status in a Biracial Sample of Well-Functioning, Community-Dwelling Elderly: The Health, Aging, and Body Composition Study. American Journal of Clinical Nutrition 2004, 79 (2), 295-302. https://doi.org/10.1093/ajcn/79.2.295.

(18) O'Keeffe, M.; Kelly, M.; O’Herlihy, E.; O’Toole, P. W.; Kearney, P. M.; Timmons, S.; O'Shea, E.; Stanton, C.; Hickson, M.; Rolland, Y.; Sulmont Rossé, C.; Issanchou, S.; Maitre, I.; Stelmach-Mardas, M.; Nagel, G.; Flechtner-Mors, M.; Wolters, M.; Hebestreit, A.; De Groot, L. C. P. G. M.; van de Rest, O.; Teh, R.; Peyron, M. A.; Dardevet, D.; Papet, I.; Schindler, K.; Streicher, M.; Torbahn, G.; Kiesswetter, E.; Visser, M.; Volkert, D.; O'Connor, E. M. Potentially Modifiable Determinants of Malnutrition in Older Adults: A Systematic Review. Clinical Nutrition. Churchill Livingstone December 1, 2019, pp 24772498. https://doi.org/10.1016/j.clnu.2018.12.007.

(19) Peinado, I.; Koutsidis, G.; Ames, J. Production of Seafood Flavour Formulations from Enzymatic Hydrolysates of Fish By-Products. LWT - Food Science and Technology 2016, 66, 444-452. https://doi.org/10.1016/j.Iwt.2015.09.025.

(20) U.S. Department of Agriculture, A. R. S. FoodData Central. 
(21) Bandarra, N. M.; Marçalo, A.; Cordeiro, A. R.; Pousão-Ferreira, P. Sardine (Sardina Pilchardus) Lipid Composition: Does It Change after One Year in Captivity? Food Chemistry 2018, 244, 408-413. https://doi.org/10.1016/J.FOODCHEM.2017.09.147.

(22) Lopez, A. F. Development of Smoked Products from Sea Bass (Dicentrarchus Labrax L.).; ProQuest, 2008.

(23) Liu, S.; Fukuoka, M.; Sakai, N. Dielectric Properties of Fish Flesh at Microwave Frequency. Food Science and Technology Research 2012, 18 (2), 157-166. https://doi.org/10.3136/fstr.18.157.

(24) Saeed, S.; Howell, N. K. Effect of Lipid Oxidation and Frozen Storage on Muscle Proteins of Atlantic Mackerel (Scomber Scombrus). Journal of the Science of Food and Agriculture 2002, 82 (5), 579-586. https://doi.org/10.1002/jsfa.1080.

(25) Tejada, M.; Mohamed, G. F.; Huidobro, A.; García, M. L. Effect of Frozen Storage of Hake, Sardine and Mixed Minces on Natural Actomyosin Extracted in Salt Solutions. Journal of the Science of Food and Agriculture 2003, 83 (13), 1380-1388. https://doi.org/10.1002/jsfa.1555.

(26) Sikorski, Z. E.; Kołakowska, A. Changes in Proteins in Frozen Stored Fish. In Seafood proteins; Springer, 1994; pp 99-112.

(27) Desai, A. S.; Brennan, M. A.; Guo, X.; Zeng, X.-A.; Brennan, C. S. Fish Protein and Lipid Interactions on the Digestibility and Bioavailability of Starch and Protein from Durum Wheat Pasta. Molecules 2019, 24 (5), 839.

(28) Paz-Yépez, C.; Peinado, I.; Heredia, A.; Andrés, A. Influence of Particle Size and Intestinal Conditions on in Vitro Lipid and Protein Digestibility of Walnuts and Peanuts. Food Research International 2019, 119 , 951-959. https://doi.org/10.1016/j.foodres.2018.11.014.

(29) Santos, M. N.; Saldanha, H. J.; Gaspar, M. B.; Monteiro, C. C. Hake (Merluccius Merluccius L., 1758) Ghost Fishing by Gill Nets off the 
Algarve (Southern Portugal). Fisheries Research 2003, 64 (2-3), 119128. https://doi.org/10.1016/S0165-7836(03)00211-X.

(30) Levi, S.; Lesmes, U. Bi-Compartmental Elderly or Adult Dynamic Digestion Models Applied to Interrogate Protein Digestibility †. 2014. https://doi.org/10.1039/c4fo00478g.

(31) Rémond, D.; Shahar, D. R.; Gille, D.; Pinto, P.; Kachal, J.; Peyron, M. A.; Dos Santos, C. N.; Walther, B.; Bordoni, A.; Dupont, D.; TomásCobos, L.; Vergères, G. Understanding the Gastrointestinal Tract of the Elderly to Develop Dietary Solutions That Prevent Malnutrition. Oncotarget 2015, 6 (16), 13858-13898. https://doi.org/10.18632/oncotarget.4030.

(32) Usydus, Z.; Szlinder-Richert, J.; Adamczyk, M. Protein Quality and Amino Acid Profiles of Fish Products Available in Poland. Food Chemistry 2009, 112 (1), 139-145. https://doi.org/10.1016/j.foodchem.2008.05.050.

(33) Özyurt, G.; Polat, A. Amino Acid and Fatty Acid Composition of Wild Sea Bass (Dicentrarchus Labrax): A Seasonal Differentiation. European Food Research and Technology 2006, 222 (3-4), 316-320. https://doi.org/10.1007/s00217-005-0040-z.

(34) Nieva-Echevarría, B.; Goicoechea, E.; Manzanos, M. J.; Guillén, M. D. Usefulness of $1 \mathrm{H}$ NMR in Assessing the Extent of Lipid Digestion. Food Chemistry 2015, 179, 182-190. https://doi.org/10.1016/J.FOODCHEM.2015.01.104.

(35) Salvia-Trujillo, L.; Verkempinck, S. H. E.; Sun, L.; Van Loey, A. M.; Grauwet, T.; Hendrickx, M. E. Lipid Digestion, Micelle Formation and Carotenoid Bioaccessibility Kinetics: Influence of Emulsion Droplet Size. Food Chemistry 2017, 229, 653-662. https://doi.org/10.1016/j.foodchem.2017.02.146.

(36) Toth, M. J.; Tchernof, A. Lipid Metabolism in the Elderly. European Journal of Clinical Nutrition 2000, 54 (3), S121-S125. https://doi.org/10.1038/sj.ejcn.1601033. 
(37) Choudhury, D.; Tuncel, M.; Levi, M. Disorders of Lipid Metabolism and Chronic Kidney Disease in the Elderly. 2009. https://doi.org/10.1016/j.semnephrol.2009.07.006.

(38) Calvo-Lerma, J.; Fornés-Ferrer, V.; Heredia, A.; Andrés, A. In Vitro Digestion Models to Assess Lipolysis: The Impact of the Simulated Conditions on Gastric and Intestinal PH, Bile Salts and Digestive Fluids. Food Research International 2019. https://doi.org/10.1016/j.foodres.2019.108511.

(39) Shani Levi, C.; Goldstein, N.; Portmann, R.; Lesmes, U. Emulsion and Protein Degradation in the Elderly: Qualitative Insights from a Study Coupling a Dynamic in Vitro Digestion Model with Proteomic Analyses. Food Hydrocolloids 2017, 69, 393-401. https://doi.org/10.1016/j.foodhyd.2017.02.017.

(40) Peng, J.; Larondelle, Y.; Pham, D.; Ackman, R. G.; Rollin, X. Polyunsaturated Fatty Acid Profiles of Whole Body Phospholipids and Triacylglycerols in Anadromous and Landlocked Atlantic Salmon (Salmo Salar L.) Fry. Comparative Biochemistry and Physiology - B Biochemistry and Molecular Biology 2003, 134 (2), 335-348. https://doi.org/10.1016/S1096-4959(02)00263-4.

(41) Eroldoğan, T. O.; Yilmaz, A. H.; Turchini, G. M.; Arslan, M.; Sirkecioğlu, N. A.; Engin, K.; Özşahinoğlu, I.; Mumoğullarinda, P. Fatty Acid Metabolism in European Sea Bass (Dicentrarchus Labrax): Effects of n-6 PUFA and MUFA in Fish Oil Replaced Diets. Fish Physiology and Biochemistry 2013, $39 \quad$ (4), 941-955. https://doi.org/10.1007/s10695-012-9753-7.

(42) Etcheverry, P.; Grusak, M. A.; Fleige, L. E. Application of in Vitro Bioaccessibility and Bioavailability Methods for Calcium, Carotenoids, Folate, Iron, Magnesium, Polyphenols, Zinc, and Vitamins B 6, B 12, D, and E. Frontiers in Physiology. 2012. https://doi.org/10.3389/fphys.2012.00317.

(43) Moreda-Piñeiro, J.; Moreda-Piñeiro, A.; Romarís-Hortas, V.; Domínguez-González, R.; Alonso-Rodríguez, E.; López-Mahía, P.; 
Muniategui-Lorenzo, S.; Prada-Rodríguez, D.; Bermejo-Barrera, P. ICP-MS for the Determination of Selenium Bioavailability from Seafood and Effect of Major Food Constituents. Microchemical Journal 2013, 108, 174-179. https://doi.org/10.1016/j.microc.2012.10.019.

(44) Titchenal, C. A.; Dobbs, J. A System to Assess the Quality of Food Sources of Calcium. Journal of Food Composition and Analysis 2007, 20 (8), 717-724.

(45) Werner, A.; Kuipers, F.; Verkade, H. J. Fat Absorption and Lipid Metabolism in Cholestasis. In Madame Curie Bioscience Database [Internet]; Landes Bioscience, 2013.

(46) Michigami, T. Skeletal Mineralization: Mechanisms and Diseases. Ann Pediatr Endocrinol Metab 2019, 24 (4), 213-219. https://doi.org/10.6065/apem.2019.24.4.213. 
5.2 Chapter 2: Understanding the role of food matrix on the digestibility of dairy products under elderly gastrointestinal conditions.

Ever Hernández-Olivas, Sara Muñoz-Pina, Janaina Sánchez-García, Ana Andrés and Ana Heredia

Food Research International 2020, 137. https://doi.org/10.1016/j.foodres.2020.109454. 


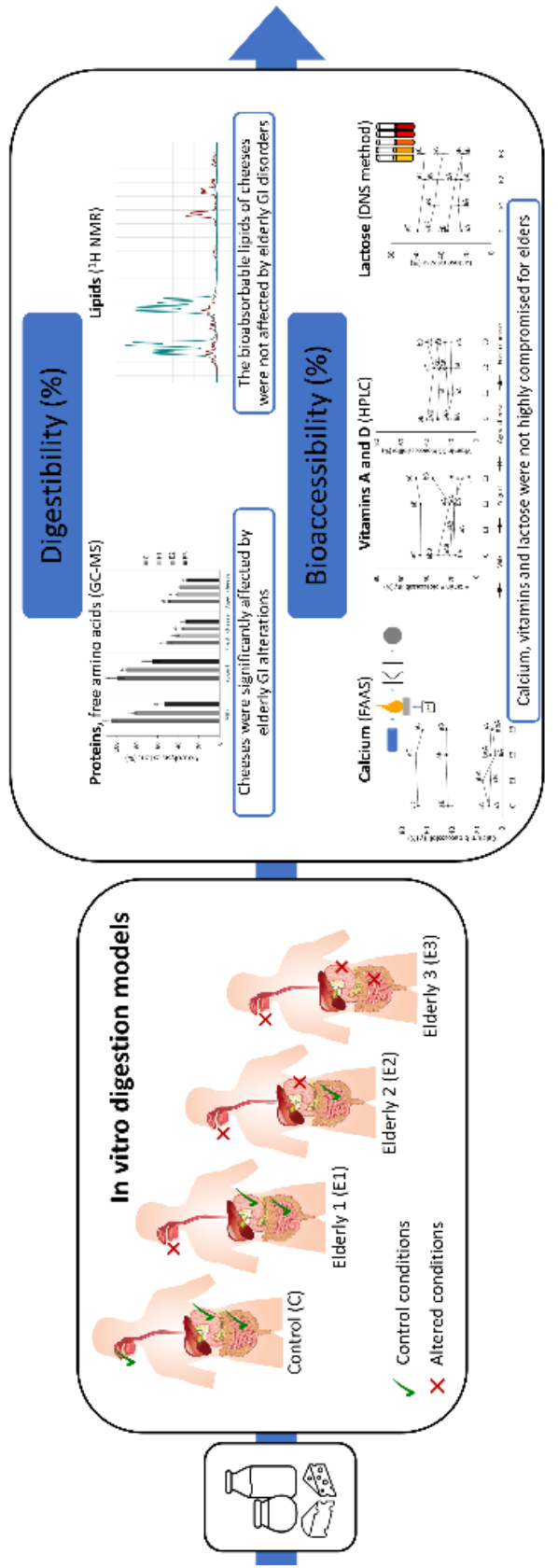




\section{Abstract}

This study aimed to evaluate the effect of some elderly in vitro gastrointestinal $(\mathrm{Gl}$ ) conditions on proteolysis and lipolysis extent, calcium, vitamins $A$ and $D$ bioaccessibility and lactose release in milk, yogurt, fresh and aged cheeses. To evaluate the impact of the some oral, gastric and intestinal disorders appearing with ageing on dairy digestion, three in vitro elderly models were applied (E1 (oral altered conditions), E2 (oral and gastric altered conditions) and E3 (oral, gastric and intestinal altered conditions)) plus a healthy adult one as control. Proteolysis extent was significantly affected by elderly Gl alterations $(p<0.05)$ (around $40 \%$ of reduction compared to control), being fresh and aged cheese proteolysis the most affected with an important decrease in leucine release (18 and $25 \%$, respectively). Calcium, vitamins A and D3bioaccesibility and lactose release seemed not to be highly compromised in these models of elderly conditions; however, the micronutrients bioaccessibility was very dependent on dairy matrix's structure. Finally, the amount of the lipid hydrolyzed fraction of cheeses is not influenced in the investigated models.

Keywords: Dairy products; Elderly in vitro digestion models; Protein digestibility; Fat digestibility; Micronutrients bioaccessibility; Lactose release 


\section{INTRODUCTION}

Population group above 65 years old is growing, expecting to be in Europe more than one-quarter (27\%) by $2050^{1}$. Worldwide, it is expected that the number of people over 65 will exceed the number of children for the first time in 2045. Both lifestyle and diet present an impact on elderly wellness and therefore, on the prevalence of chronical diseases in this population group. Therefore, specific nutrition for elderly has been identified as one of the rising world's challenges ${ }^{2}$. Among the dietary recommendations addressed to individuals over 65 years by European Society for Clinical Nutrition and Metabolism (ESPEN), an intake of rich-protein foods is highly advisable ${ }^{3}$, and preferably with a protein profile rich in leucine ${ }^{4}$. Among food categories contributing the most to protein intake through the diet, dairy products are highly consumed by elderly and more specifically, yogurt and cheese ${ }^{1}$. These products present a positive impact on cardiovascular health ${ }^{5}$ and especially have shown to contribute to bone health in individuals over 65 years ${ }^{6}$, because of their protein, calcium and liposoluble vitamins content. A protein deficit in elderly has been associated with a loss of muscle mass (sarcopenia), asthenia, depression and weakness of the immune system ${ }^{7}$. Gastrointestinal disorders appearing along ageing could be partially responsible of this protein deficit because they frequently lead to less hydrolysis and absorption of macronutrients, especially of proteins. Among them, secretion of digestive fluids and enzymes, peristaltic contractions and chyme passage rates could be suboptimal ${ }^{8,9}$. Besides, micronutrients bioaccessibility is often compromised, as it is the case of calcium and zinc, and/or some vitamins such as B12, B6, A and D.

Besides to the host-related factors, it is expected that the characteristics inherent to the food matrix (composition, structure, physicochemical properties or interactions between macro and micronutrients within the same matrix, ...) also modulate digestibility, resulting in different extents of hydrolysis under similar digestive conditions. Nevertheless, these food- 
inherent and host-related factors are barely considered when addressing dietetic recommendations to elderly.

Given this scenario, it was considered of interest to carry out an in vitro digestion study to assess the contributions of food-inherent and hostrelated factors to different dairy products digestibility under altered digestion conditions frequently given in senior population. The results might generate accurate dietetic recommendations for elderly and open the door to the design of new functional products addressed to senior. In vitro digestion models allow simulating the digestion processes with a series of advantages compared to in vivo ones. They are highly reproducible, easy to sampling in the different stages of the digestive process and allow modifications of the controlled digestion conditions, among others.

Thus, the aim of the present work is to assess, by means of a static in vitro digestion methodology, the influence of the most frequent elderly GI alterations according to the model published by Shani-Levi et al. (2017) ${ }^{10}$ onto the digestibility of macronutrients (proteins, fats and carbohydrates) and the bioaccessibility of micronutrients (calcium and vitamin A and D3) in four different dairy products (whole milk, yogurt, fresh and aged cheeses).

\section{MATERIAL AND METHODS}

\section{Chemicals}

Reagents for the in vitro simulation of digestion fluids were pepsin from the porcine gastric mucosa (P6887), porcine pancreatin (P7545), bovine bile (B3883), potassium chloride, potassium dihydrogen phosphate, sodium bicarbonate, sodium chloride, magnesium chloride, ammonium carbonate, calcium chloride, hydrochloric acid, sodium hydroxide and potassium sulphate, all of them from Sigma-Aldrich (Sigma-Aldrich, USA).

For the analytical determinations, boric acid, tetrahydrofuran (HPLC grade), methanol (HPLC grade), retinol $\geq 99 \%$ (HPLC grade), cholecalciferol $\geq 98 \%$ (HPLC grade), sulfuric acid, glucose standard solution $(1 \mathrm{mg} / \mathrm{mL})$, potassium 
sodium tartrate tetrahydrate (ACS reagent, 99\%) and 3,5-dinitrosalicylic acid were also provided by Sigma-Aldrich (Sigma-Aldrich, USA). Nitric acid (70\%), lanthanum chloride heptahydrate and dichloromethane (HPLC grade $>$ 99.8\%) were acquired from Honeywell Fluka (Buchs, Switzerland) and petroleum ether from VWR International (VWR International, France). Sodium chloride and anhydrous sodium sulfate were supplied by Panreac (Panreac AppliChem, Barcelona, Spain). The EZ-Faast amino acid analysis kit for the analysis of amino acids by GC-MS was provided by Phenomenex (Torrance, CA, USA) and acetonitrile HPLC grade was acquired from JT Baker (Phillipsburg, NJ, USA)

The four selected dairy products for this study (whole milk, natural yogurt, 12-monthaged cheese and fresh cheese) were all exclusively of cow origin $(100 \%)$ and acquired in a local store of the city of Valencia, Spain.

\section{Compositional analysis of dairy products}

Moisture, ashes, fat and protein contents were determined according to the official methods 934.01, 942.05, 920.39 and 960.52 of the Association of Official Analytical Chemist ${ }^{11}$, respectively. For fluid matrices (milk and yogurt), the above- methodologies were carried out, excepting for the fat analysis that followed the methodology of the International Standard ISO 1211 | IDF 001: 2010, 12. Furthermore, lactose content(as glucose equivalent) was determined by the colorimetric method of dinitrosalicylic acid (DNS) ${ }^{13}$.

Calcium content was determined according to the methodology proposed by ${ }^{14}$ using a flame atomic absorption spectrometer at $422.7 \mathrm{~nm}$ (Thermo Scientific, iCE 3000 Series), previous calcination of the sample.

Samples were also subjected to saponification and extraction of both vitamin A (retinol) and D3 (cholecalciferol) according to the protocol of Castaneda \& Lee, $(2019)^{15}$. Vitamins were first separated using a RP-HPLC 
(Waters e2695 Separation Module, Waters, Milford, MA, USA) with a Kinetex ${ }^{\mathrm{TM}} \mathrm{C} 18$ column $5 \mu \mathrm{m}, 100 \AA$, $150 \times 4.6$ mm (Phenomenex, Torrance, CA, USA). An isocratic separation was performed with $15 \%$ acetonitrile, $7 \%$ water and $78 \%$ methanol:tetrahydrofurane $(90: 10 \mathrm{v} / \mathrm{v})$ during $10 \mathrm{~min}$ using a flow rate of $1 \mathrm{~mL} / \mathrm{min}$ and an injection volume of $20 \mu \mathrm{L}$. Then, they were detected and quantified using a photo diode array detector (Waters PDA 2996) at $265 \mathrm{~nm}$ (vitamin D3) and $325 \mathrm{~nm}$ (vitamin A).

All above-mentioned macro and micronutrients were expressed per $\mathrm{g}$ of dairy product.

Finally, fresh and aged cheeses were subjected to cold liquid-liquid extraction to determine their lipidic profile by Proton Nuclear Magnetic Resonance ( ${ }^{1} \mathrm{H}$ NMR) using a BRUKER $400 / \mathrm{R}$ at $400 \mathrm{MHz}{ }^{16}$. The lipidic profile provides information about the molar percentage of triglycerides (TG), diglycerides (1,2-DG and 1,3-DG), monoglycerides (1-MG and 2-MG) and free fatty acids (FFA) in the samples.

\section{Static in vitro simulation of the digestive process}

The simulation of gastrointestinal digestion was carried out following the standardized method of static in vitro digestion for a healthy adult, internationally agreed and published by Minekus et al. (2014) ${ }^{17}$. On the other hand, the specific gastrointestinal conditions of the elderly were established according to Shani-Levi et al. (2017) ${ }^{10}$. For the first step of the digestion, oral stage, it was decided to perform an in vivo simulation realized by a healthy subject, only in the case of solid food since in the case of milk and yogurt this stage was suppressed. As chewing is a complex process where parameters such as the number of cycles, chewing frequency and speeds depend on the food characteristics ${ }^{18-20}$, it is difficult to establish a chewing standard. Therefore, taken this into account and based on the publications of other authors, the number of chewing cycles needed to reach a bolus with similar physical characteristics to that of a tomato or 
mustard paste were determined for each solid product and considered the standard conditions of a volunteer adult with healthy dentition ${ }^{17,21,22}$, and then to simulate the altered chewing conditions of a most critical oral elderly scenery the number of cycles was reduced by $50 \%$ in order to generate boluses with larger particle size and difficult to swallow ${ }^{23-25}$.

Four in vitro models were designed to study the impact of different gastrointestinal alterations on the elderly population on the digestibility and bioaccessibility of dairy products: first one representing the standard GI conditions of a healthy adult (control (C)) and three models mimicking the accumulative alterations commonly observed with ageing (Elderly 1 (oral stage altered (E1), Elderly 2 (oral and gastric stages altered (E2)) and Elderly 3 (oral, gastric and intestinal stages altered) (E3))) (Figure 5.2.1).

In vitro digestion was performed as follows:

Oral stage: in the case of fresh and aged cheese, $5 \mathrm{~g}$ of sample were chewed in vivo by the volunteer with normal dentition during 20 cycles simulating a healthy adult. In contrast, 10 cycles were performed to simulate an elderly. After chewing, food boluses were transferred to the falcon tubes to continue gastrointestinal digestion.

Gastric stage: food boluses of fresh and aged cheeses, or a direct aliquot of yogurt and milk, were mixed in a ratio 1:1 with SGF (v/v) and the $\mathrm{pH}$ and the pepsin concentration was adjusted according to the conditions to be tested (Figure 5.2.1). Subsequently, the samples were flipped from top to bottom at 55 rpm using an Intell-Mixer RM-2 (Elmi Ltd, Riga, LV-1006, Latvia) for $2 \mathrm{~h}$ at $37^{\circ} \mathrm{C}$ in a chamber Selecta (JP Selecta SA, Barcelona).

Intestinal stage: After the gastric stage, SIF was incorporated in a proportion $1: 1(\mathrm{v} / \mathrm{v})$ to each tube containing the gastric chime according to the conditions of the models (Figure 5.2.1). Samples were then being flipped from top to bottom at $55 \mathrm{rpm}$ for another 2 or $4 \mathrm{~h}$, depending on the model 
tested, at $37{ }^{\circ} \mathrm{C} . \mathrm{pH}$ was monitored during the digestion process and readjusted if necessary, to keep it constant.

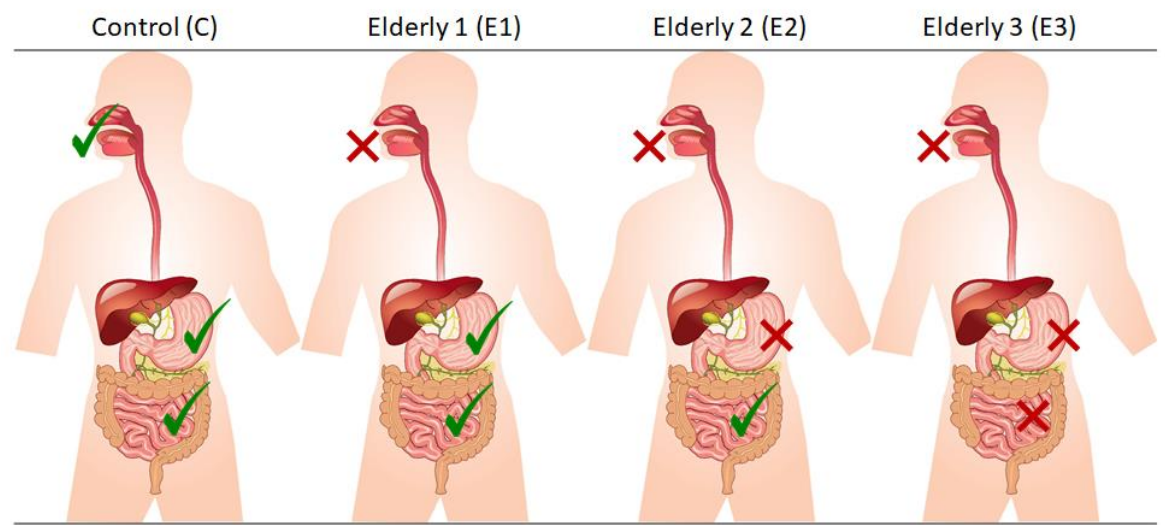

Control conditions: Oral stage: chewing cycles until consistency like a tomato paste Gastric stage: $\mathrm{pH}$ 3, Pepsin $2000 \mathrm{U} / \mathrm{mL}, 2 \mathrm{~h}$ Intestinal stage: $\mathrm{pH} 7$, Bile $10 \mathrm{mM}$, pancreatin $100 \mathrm{U} / \mathrm{mL}, 2 \mathrm{~h}$ Altered conditions: Oral stage: $50 \%$ control chewing cycles Gastric stage: $\mathrm{pH}$ 6, Pepsin $1500 \mathrm{U} / \mathrm{mL}, 2 \mathrm{~h}$ Intestinal stage: $\mathrm{pH} 7$, Bile $5 \mathrm{mM}$, pancreatin $50 \mathrm{U} / \mathrm{mL}$, $4 \mathrm{~h}$

Figure 5.2.1. Specific gastrointestinal conditions of the four in vitro digestion models applied to mimic healthy adult standardized conditions (C: control)) and elderly Gl alterations (E1: Elderly 1; E2: Elderly 2; E3: Elderly 3).

At the end of the digestion, samples were cooled down in ice bath during 10 $\min$ to reduce the digestion before phase separation and analytical determinations. Where needed, separation of the liquid phase from the solid phase resulting from the digestion process was performed by centrifuging at $4000 \mathrm{~g}$-force during 20 minutes at $10^{\circ} \mathrm{C}$ and the supernatant, considered as bioaccessible fraction, was collected for analytical determinations.

\section{Analytical determinations in the digesta}

\section{Free amino acids}


The determination of free amino acids resulting of protein digestion was performed using the EZ-Faast amino acid kit following the procedure proposed by Peinado et al. $(2016)^{26}$. First, aliquots of bioaccesible fraction $(100 \mu \mathrm{L})$ were taken to be derivatized using EZ-Faast amino acid kit and then analyzed by gas chromatography-mass spectrometry (GC-MS) (Agilent Technologies, Injector 7683B series, Network GC System 6890N series, Inert Mass Selective Detector 5975 series. Data from both the calibration curve and the samples were analyzed using the MSD ChemStation software. The amino acid profile after digestion was expressed as $\mathrm{mg}$ free amino acid/ $\mathrm{g}$ product and proteolysis extent (\%), with respect to the initial protein content, according to Eq 5.4:

$$
\text { Proteolysis extent }(\%)=\frac{(\text { total } g \text { of free amino acids })}{(g \text { initial protein })} \times 100
$$

\section{Lipidic profile determination}

Digesta from both fresh and aged cheeses were subjected to same protocol for lipidic profile determination and described in section of compositional analysis for undigested cheeses.

\section{Lactose released}

Lactose content, expressed as $\mathrm{mg}$ glucose eq/ $\mathrm{g}$ of initial product, was determined in $0.5 \mathrm{~mL}$ of the bioaccessible fraction by the colorimetric method of Dinitrosalicylic Acid (DNS) ${ }^{13}$. Lactose released (\%), with respect to the initial content, was estimated according to Eq.5.5.

Lactose released (\%)

$$
=\frac{(m g \text { glucose eq. released })}{(m g \text { glucose eq. total in undigested food })} \times 100
$$




\section{Calcium bioaccessibility}

An aliquot of $4 \mathrm{~mL}$ was taken from the bioaccessible fraction and subjected to the same protocol explained in the section of compositional analysis. Calcium content in the bioaccessible fraction was expressed as $\mathrm{mg}$ of $\mathrm{Ca}^{2+} /$ $\mathrm{g}$ of initial product and its bioaccessibility (\%) calculated according to Eq. 5.6; where "free $\mathrm{Ca}^{2+}$ released" refers to the calcium content in the bioaccessible fraction and " $\mathrm{Ca}^{2+}$ in undigested food" to the total calcium content in the dairy product before digestion.

Calcium bioaccessibility (\%)

$$
=\frac{\left(m g C a^{2+} \text { released }\right)}{\left(m g C a^{2+} \text { in undigested food }\right)} \times 100
$$

\section{Vitamin A and D3 bioaccessibility}

Vitamins A and D3 were determined in $20 \mathrm{~mL}$ of bioaccessible fraction according to the protocol described in the section of compositional analysis and expressed as $\mu \mathrm{g} / \mathrm{g}$ of initial product. Subsequently, their bioaccessibility was calculated according to Eq. 5.7 in which "vitamin released" refers to the vitamin content in the bioaccessible fraction, and "vitamin in the undigested food" to the vitamin content in dairy product before digestion.

Vitamin bioaccessibility (\%)

$$
=\frac{(\mu \mathrm{g} \text { of vitamin released })}{(\mu \mathrm{g} \text { of vitamin in undigested } \mathrm{food})} \times 100
$$

\section{Statistical analysis}

Data are reported as mean \pm standard deviation (three replicates). The results obtained were statistically analyzed using Statgraphics Centurion 
XVII program with a 95\% confidence level $(p<0.05)$ using a simple analysis of variance (one-way ANOVA) followed by the multiple range test LSD (Less Significant Difference) of Fisher test in order to identify homogeneous groups between models and dairy products. PCA was used an orthogonal transformation to convert the obtained data (proteolysis, lipolysis, lactose release and bioaccessibilities of calcium, vitamin A and D3) of possibly correlated variables into a set of values of linearly uncorrelated variables (called principal components). This transformation is defined in such a way that the first principal component has the largest possible variance (that is, accounts for as much of the variability in the data as possible), and each succeeding component in turn has the highest variance possible under the constraint that it is orthogonal to the preceding components.

\section{RESULTS AND DISCUSSION}

\section{Nutritional composition of the samples}

The nutritional contents of milk, yogurt, fresh and aged cheeses, expressed per $1 \mathrm{~g}$ of product, are gathered in Table 5.2.1 In general, protein, total fat and ashes contents were similar to those reported in literature for the same food matrices ${ }^{27-29}$ and correspond to label declarations. As expected, both cheeses ( 0.16 and $0.29 \mathrm{~g} / \mathrm{g}$ product, for fresh an aged cheese) presented higher protein content than yogurt and milk (around $0.03 \mathrm{~g} / \mathrm{g}$ product). In terms of lipid content, dairy products ranged from 0.0287 to $0.288 \mathrm{~g} / \mathrm{g}$ product, corresponding to yogurt the least content and to aged cheese the most. Thus, the processing (coagulation, pressing, salting and/or curing) resulting in different composition of matrices ${ }^{30}$. With regard to calcium content of the different dairy products, results were consistent with those reported in the literature ${ }^{31,32}$, reporting $1 \mathrm{~g}$ of cheeses provides more calcium mineral than the same amount of liquid or semi-liquid dairy products. Vitamins A and D3 contents were also in agreement with data found in the literature ${ }^{31,32}$. According to these results, the studied dairy 
products can be considered as an important source of liposoluble vitamins, and especially of retinol. However, differences in terms of vitamins concentration were also noticed. Aged cheese presented notable higher content of both vitamins, A and D3, compared to the other dairy products. With respect to lactose content, milk presented the highest sugar content compared to the other products. As it is well-known, lactose consumption by lactic acid bacteria during fermentation results in lower lactose content in yogurt than milk. During cheese production, the whey removal (in which lactose is solubilized) after acidic or enzymatic coagulation, gives as a result 
Table 5.2.1. Macro and micronutrients contents in dairy products (milk, yogurt, fresh cheese and aged cheese) expressed per $g$ of product.

\begin{tabular}{|c|c|c|c|c|}
\hline \multirow[b]{2}{*}{ Nutrient } & & & & \\
\hline & Milk & Yogurt & Fresh cheese & Aged cheese \\
\hline Moisture (g/g product) & $0.882 \pm 0.002^{d}$ & $0.895 \pm 0.0009^{c}$ & $0.618 \pm 0.009^{b}$ & $0.362 \pm 0.012^{a}$ \\
\hline Protein (g/g product) & $0.0303 \pm 0.0012^{\mathrm{a}}$ & $0.0319 \pm 0.0019^{\mathrm{a}}$ & $0.163 \pm 0.008^{b}$ & $0.29 \pm 0.007^{c}$ \\
\hline Fat (g/g product) & $0.035 \pm 0.001^{b}$ & $0.0287 \pm 0.0012^{\mathrm{a}}$ & $0.202 \pm 0.015^{c}$ & $0.288 \pm 0.012^{d}$ \\
\hline Ashes (g/g product) & $0.0053 \pm 0.0003^{\mathrm{a}}$ & $0.0073 \pm 0.0006^{b}$ & $0.0092 \pm 0.0002^{c}$ & $0.03 \pm 0.003^{d}$ \\
\hline $\begin{array}{l}\text { Lactose (mg glucose eq./g } \\
\text { product) }\end{array}$ & $57 \pm 4^{d}$ & $25.3 \pm 1.5^{c}$ & $20.7 \pm 1.2^{\mathrm{b}}$ & $4 \pm 0.6^{a}$ \\
\hline Calcium (mg/g product) & $1.47 \pm 0.09^{b}$ & $1.19 \pm 0.02^{\mathrm{a}}$ & $12.6 \pm 0.5^{c}$ & $14.1 \pm 0.5^{d}$ \\
\hline Vitamin A ( $\mu \mathrm{g} / \mathrm{g}$ product) & $0.55 \pm 0.02^{b}$ & $0.45 \pm 0.04^{a}$ & $1.03 \pm 0.07^{c}$ & $3.4 \pm 0.2^{d}$ \\
\hline Vitamin D3 ( $\mu \mathrm{g} / \mathrm{g}$ product) & $0.0397 \pm 0.0013^{b}$ & $0.031 \pm 0.0013^{\mathrm{a}}$ & $0.138 \pm 0.005^{c}$ & $0.216 \pm 0.014^{d}$ \\
\hline
\end{tabular}

Data shown are mean values from triplicates and the standard deviation. ${ }^{\text {a-d }}$ Different lowercase letters indicate significant differences between foods $(p<0.05)$. 
low lactose content in fresh cheese; while lactose conversion to lactate during the two weeks of ripening additionally decrease the residual lactose present in aged cheeses ${ }^{33}$. Of note, important differences exist among products in terms of protein and micronutrients contributions per serving to the daily diet. In fact, a serving of milk (averaged serving of $200 \mathrm{~mL}$ ) or aged cheese ( $40 \mathrm{~g}$ ) puts up to the diet with higher protein and liposoluble vitamins contents, than the intake of a serving of yogurt (125 g) or fresh cheese (40g); while the consumption of whatever of the cheeses is interesting in order to insure high calcium intake. Nevertheless, the affection of gastrointestinal alterations of elderly on macro and micronutrients digestibility and availability might be consider to address dietary recommendations.

\section{Protein digestibility of dairy products under elderly GI conditions}

Figure 5.2.2 shows the digested protein ( $\mathrm{mg}$ of free amino acids/ $\mathrm{g}$ of product) and the proteolysis extent (\%) of dairy products (milk, yogurt, fresh cheese and aged cheese) digested under standard (C) and elderly scenarios (E1, E2 and E3). Firstly, it can be noted that the amount of digested protein under standardized GI conditions (C) ranged between 31.3 to $131 \mathrm{mg}$ free amino acids/g product (for yogurt and aged cheese, respectively) and proteolysis extent from 50 to $100 \%$, depending on the food matrix. Nevertheless, higher values of proteolysis extent do not necessarily correspond to higher supplies of free amino acids per gram of product.

Dairy structure plays a key role on the solubilization, release and/or hydrolysis of caseins during the $\mathrm{Gl}$ digestion ${ }^{27}$, being caseins taking part of solid structures (fresh and aged cheeses) less digestible than those present in liquids and semi-liquids products. Similar results were reported by Asensio-Grau et al. (2019) ${ }^{34}$ and Rinaldi et al. (2014) ${ }^{27}$. Besides, it is important to remark that ripened cheese often contains free amino acids and small peptides due to proteases activity during ripening ${ }^{35}$. Proteolysis 
extent in 12-month ripened cheeses has been reported to range from 2 to $8 \%$, when no fungal microorganism are involved ${ }^{36,37}$. Therefore, proteolysis resulting from digestion in cheeses could be slightly lower than showed in Figure 5.2.2 Some studies have reported that the presence of products of hydrolysis such as free amino acids in ripened cheeses could enhance the breakdown of caseins during the posterior $\mathrm{Gl}$ digestion because of their emulsifying capacity ${ }^{34,38}$. However, no differences were found in terms of proteolysis extent among fresh, without ripening, and aged cheese in this study.

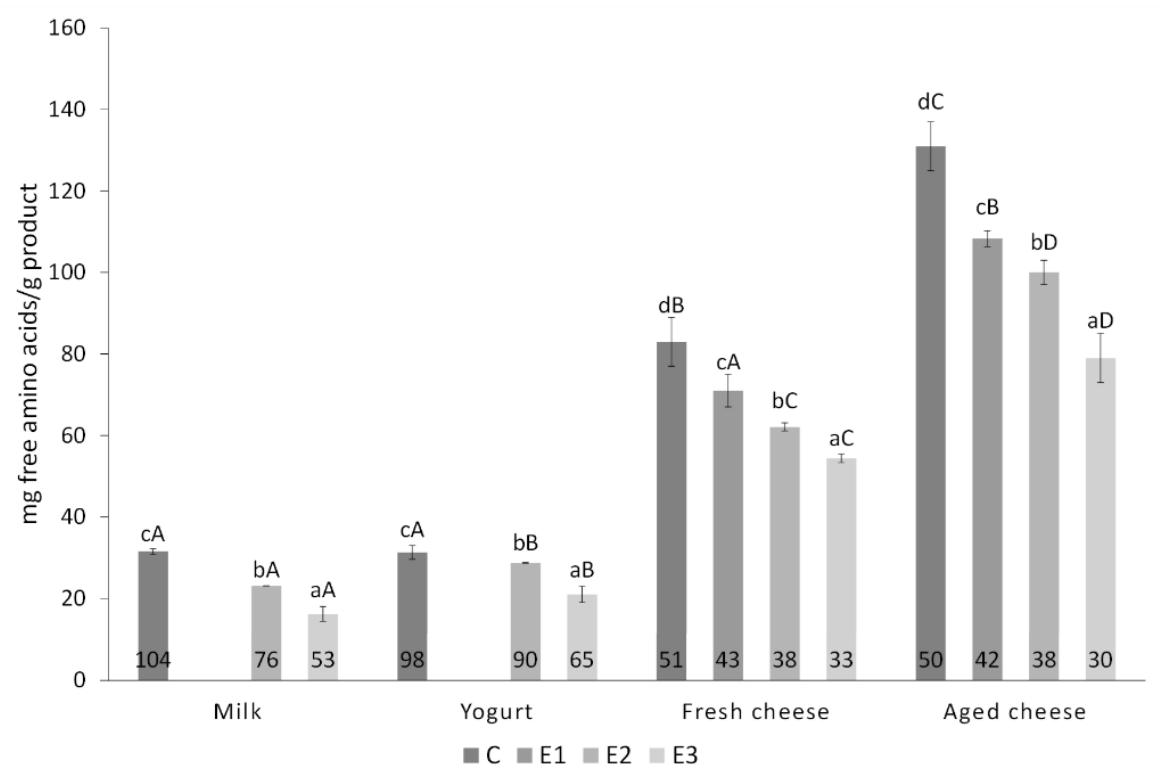

Figure 5.2.2. Digested protein ( $m g$ free amino acids/g product) of milk, yogurt, fresh cheese and aged cheese under different in vitro digestion models (C: control; E1: Elderly 1; E2: Elderly 2; E3: Elderly 3). Values at the bottom of the bars represent the proteolysis extent (\%) achieved after in vitro digestion. Oral alterations (E1) in milk and yogurt were not evaluated because of the absence of mastication, and therefore the low saliva secretion in the oral cavity. a-d different lowercase letters indicate 
significant differences between models $(p<0.05)$. A-D different capital letters indicate significant differences between products $(p<0.05)$.

Regarding the effect of altered Gl conditions of elderly on proteolysis, protein hydrolysis experimented an accumulative reduction as long as the $\mathrm{Gl}$ conditions were altered from the oral to the intestinal stage in fresh and aged cheese and from the gastric to the intestinal stage in milk and yogurt. Hence, a proteolysis extent of $32 \pm 3,33 \pm 3,53 \pm 7,65 \pm 8 \%$ for aged cheese, fresh cheese, milk and yogurt were registered under the worst scenario of digestion for elderly E3). From standard (C) to elderly GI conditions, $65 \%$ of reduction was observed for solid and semi-solid dairy products and $50 \%$ for milk. Yogurt and milk presented the highest protein digestibility under all GI conditions, but lower amount of free amino acid supply than both cheeses. Therefore, the impact level of elderly GI conditions on the protein in vitro digestion is dependent on the matrix-inherent properties. To deeper, $\mathrm{C}$ and E1 models differ in oral stage conditions (being major the breakdown in $\mathrm{C}$ than E1). Thus, the reduction of the food particle size and a mixing with saliva is aimed in optimal conditions to swallow. In this way, smaller particles maximize the protein surface contact, enabling better the accessibility of enzymes to cleavage sites ${ }^{39}$. This fact could explain the impact of mastication level on proteolysis achieved at the end of digestion in fresh cheese and aged cheese (Figure 5.2.2). The comparison of the proteolysis achieved under E1 and E2 models for both cheeses, and between C and E2 in milk and yogurt was aimed at evidencing the impact of gastric alteration in proteolysis extent. However, it is necessary to point out that proteolysis is estimated by free amino acids quantification at the end of luminal digestion, i.e., after intestinal stage. Consequently, the products of gastric proteolysis are mainly peptides of low molecular weight that cannot be detected by the analytical method. The results show that gastric stage change would reduce protein digestibility measured after luminal simulation in all the analyzed foods, but without significant difference in 
fresh cheese. The isoelectric point of caseins is close to $\mathrm{pH} 6(4.5<\mathrm{pH}<5.5)$, and aggregates could hinder the hydrolysis ${ }^{40}$. Thus, if protein hydrolysis into peptides decreases under 22 conditions, the analytical method was not able to register completely that fact. In any case, the similar proteolysis extent achieved E1 and E2 in cheeses, and C and E2 in milk and yogurt, indicates that the activity of pancreatic proteases might compensate the suboptimal conditions of the gastric stage (E2) with the hydrolysis of proteins into peptides and free amino acids.

Finally, a reduction in the pancreatic enzymes lead to maldigestion and malabsorption of proteins causing nutritional deficiencies ${ }^{41}$. This fact agrees to proteolysis extent resulted under suboptimal intestinal conditions (E3) compared with the proteolysis extent achieved under non-altered intestinal conditions (E2).

Tables 5.2.2 and 5.2.3 gather the free amino acid profile (mg of free amino acid/ $g$ of product) resulting of proteolysis under standard healthy adult (C) and are consistent with that reported by other authors ${ }^{30,42,43}$. As it can be observed, major free amino acids values correspond to lysine, leucine, tyrosine, valine and phenylalanine, all of them essential ones. In Particular, leucine, together with isoleucine and valine, is an amino acid of concern in the elderly, because its participation in muscle protein synthesis ${ }^{41}$. Besides, Tables 5.2.2 and 5.2.3 show the free amino acid profiles obtained after digestion under elderly conditions (E1, E2 and E3) and the reduction of each amino acid release, with respect to the control (C), occurring as consequence of elderly GI alterations (E1, E2 and E3). Thus, amino acids reduction ranged from 20 to $100 \%$ under the worst digestion conditions (E3), being glycine, cystine, asparagine, aspartic acid, threonine and alanine the free amino acids experimenting the highest reductions. Among the essential amino acids (valine, isoleucine, leucine, phenylalanine, tryptophan, histidine, lysine, threonine and methionine), the reduction ranged from $20-60 \%$, being the percentage of reduction very dependent on 
the dairy matrix. Of note, a reduction of $18,25,25$ and $44 \%$ of leucine were found in aged cheese, fresh cheese, yogurt and milk digested under E3, respectively. Similarly, the release of tryptophan, which is linked to serotonin production and better sleeping, providing relief from anxiety and depression reduction, was also compromised in elders with a higher reduction in digested milk (52\%), than in yogurt (25\%), fresh (35\%) and aged cheese (39\%).

\section{Cheese-lipolysis under elderly GI conditions}

Fat digestibility was evaluated in fresh and aged cheeses, because of their considerable fat content, after the in vitro digestion under control and elderly altered conditions. This analysis was carried out through the evaluation of the spectral data obtained from ${ }^{1} \mathrm{H}$ NMR. The spectra obtained were analyzed according to Nieva-Echevarría et al. $(2016)^{16}$ for the quantification of the main products derived from triglyceride hydrolysis (TG) after digestion. Table 5.2.4 shows molar percentages of acyl groups (AG) supported on the different glyceryl backbone structures (TG, 1,2-DG, 1,3DG, 2-MG, 1-MG) and free fatty acids (FFA), present in the non-digested and digested (C, E1, E2, E3) of fresh and aged cheese. Thus, absorbable fraction by the intestinal epithelium consists of the molar percentage of FFA, 2-MG and 1-MG, after undergoing a micellization process thanks to the presence of bile salts ${ }^{44}$; while the non-absorbable fraction would be the sum of the remaining TG, 1,2-DG and 1,3-DG. The lipolysis extent corresponds to the sum of the molar percentage of 1,2-DG, 1,3-DG, 2-MG, 1-MG and FFA. As expected, almost all fat was present as TG (around 98\%), in both cheeses before digestion. After digestion under healthy standard GI conditions (C), a lipolysis extent of $89 \%$ in fresh cheese and $82 \%$ in aged cheese occur because of the hydrolytic action of pancreatic lipase, with a conversion of TG mainly into FFA (70 and 63\% for fresh cheese and aged cheese, respectively), followed by 1,2-DG, 2-MG 1,3-DG and 1-MG. 
With respect to the elderly $\mathrm{Gl}$ conditions and their effect on fat digestibility, the absorbable fraction of fresh cheese was higher under intestinal altered 
Table 5.2.2. Amino acids profile ( $m g$ free amino acid/g protein) of milk and yogurt digested under control (C) and Elderly (E1,E2 and E3) GI conditions and reduction (\%) of amino acid released with respect to the control.

$\mathrm{mg}$ free amino acid / g product

(Reduction with respect to the control (\%))

\begin{tabular}{|c|c|c|c|c|c|c|c|c|}
\hline \multirow{3}{*}{ Amino acid } & \\
\hline & \multicolumn{4}{|c|}{ Milk } & \multicolumn{4}{|c|}{ Yogurt } \\
\hline & $\mathrm{C}$ & E1 & E2 & E3 & $\mathrm{C}$ & E1 & E2 & E3 \\
\hline Alanine & $1.566 \pm 0.014^{c}$ & - & $1.29 \pm 0.02^{\mathrm{b}}(17)$ & $0.91 \pm 0.12^{\mathrm{a}}(42)$ & $1.5 \pm 0.2^{b}$ & - & $1.40 \pm 0.14^{b}(12)$ & $0.93 \pm 0.09^{a}(39)$ \\
\hline Glycine & $0.98 \pm 0.14^{b}$ & - & $0.559 \pm 0.006^{\mathrm{a}}(43)$ & $0.27 \pm 0.08^{a}(72)$ & $0.80 \pm 0.13^{b}$ & - & $0.787 \pm 0.003^{b}(2)$ & $0.31 \pm 0.07^{a}(61)$ \\
\hline Valine & $2.20 \pm 0.03^{c}$ & - & $1.67 \pm 0.04^{b}(24)$ & $1.26 \pm 0.15^{\mathrm{a}}(43)$ & $2.12 \pm 0.09^{b}$ & - & $2.004 \pm 0.012^{b}(6)$ & $1.72 \pm 0.10^{\mathrm{a}}(19)$ \\
\hline Leucine & $3.65 \pm 0.18^{c}$ & - & $2.537 \pm 0.006^{b}(31)$ & $2.1 \pm 0.2^{\mathrm{a}}(44)$ & $3.4 \pm 0.2^{b}$ & - & $3.09 \pm 0.03^{b}(8)$ & $2.5 \pm 0.2^{\mathrm{a}}(25)$ \\
\hline Isoleucine & $1.40 \pm 0.07^{c}$ & - & $1.02 \pm 0.04^{b}(27)$ & $0.756 \pm 0.113^{a}(46)$ & $1.362 \pm 0.110^{b}$ & - & $1.400 \pm 0.007^{\mathrm{b}}(0.4)$ & $1.18 \pm 0.04^{a}(16)$ \\
\hline Threonine & $1.36 \pm 0.08^{c}$ & - & $0.89 \pm 0.06^{\mathrm{b}}(34)$ & $0.54 \pm 0.13^{a}(60)$ & $1.20 \pm 0.08^{b}$ & - & $1.028 \pm 0.014^{b}(15)$ & $0.75 \pm 0.06^{a}(37)$ \\
\hline Serine & $1.69 \pm 0.06^{c}$ & - & $1.27 \pm 0.05^{\mathrm{b}}(25)$ & $0.75 \pm 0.17^{a}(56)$ & $1.73 \pm 0.10^{\mathrm{b}}$ & - & $1.44 \pm 0.04^{b}(17)$ & $0.945 \pm 0.114^{\mathrm{a}}(45)$ \\
\hline Proline & $0.76 \pm 0.03^{c}$ & - & $0.476 \pm 0.007^{b}(38)$ & $0.34 \pm 0.06^{a}(56)$ & $0.95 \pm 0.02^{b}$ & - & $0.895 \pm 0.013^{b}(6)$ & $0.80 \pm 0.06^{a}(16)$ \\
\hline Asparagine & $0.97 \pm 0.05^{c}$ & - & $0.62 \pm 0.09^{b}(36)$ & $0.35 \pm 0.13^{a}(64)$ & $1.04 \pm 0.14^{b}$ & - & $0.95 \pm 0.04^{b}(11)$ & $0.26 \pm 0.08^{a}(75)$ \\
\hline Aspartic acid & $1.14 \pm 0.05^{c}$ & - & $0.81 \pm 0.06^{\mathrm{b}}(29)$ & $0.34 \pm 0.03^{a}(70)$ & $1.17 \pm 0.09^{b}$ & - & $1.114 \pm 0.006^{b}(5)$ & $0.70 \pm 0.10^{\mathrm{a}}(40)$ \\
\hline Methionine & $0.79 \pm 0.05^{b}$ & - & $0.47 \pm 0.02 \mathrm{a}(40)$ & $0.36 \pm 0.06^{a}(54)$ & $0.63 \pm 0.05^{b}$ & - & $0.6175 \pm 0.0010^{\mathrm{b}}(2)$ & $0.50 \pm 0.06^{a}(27)$ \\
\hline Glutamic acid & $1.77 \pm 0.10^{b}$ & - & $1.640 \pm 0.009^{b}(7)$ & $1.20 \pm 0.02^{\mathrm{a}}(33)$ & $1.99 \pm 0.13^{b}$ & - & $1.83 \pm 0.03^{\mathrm{b}}(8)$ & $1.49 \pm 0.08^{a}(25)$ \\
\hline Phenylalanine & $2.17 \pm 0.06^{c}$ & - & $1.30 \pm 0.02^{b}(40)$ & $0.92 \pm 0.12^{\mathrm{a}}(58)$ & $1.63 \pm 0.12^{\mathrm{b}}$ & - & $1.51 \pm 0.03^{b}(7)$ & $1.147 \pm 0.108^{a}(30)$ \\
\hline Glutamine & $2.06 \pm 0.19^{b}$ & - & $1.56 \pm 0.18^{\mathrm{a}}(24)$ & $1.37 \pm 0.19^{\mathrm{a}}(34)$ & $2.4 \pm 0.2^{b}$ & - & $1.79 \pm 0.04^{b}(25)$ & $1.6 \pm 0.3^{a}(41)$ \\
\hline Ornithine & & - & - & & - & - & - & - \\
\hline Lysine & $2.50 \pm 0.19^{b}$ & - & $2.568 \pm 0.003^{b}(7)$ & $1.9 \pm 0.2^{a}(31)$ & $4.0 \pm 0.4^{b}$ & - & $3.96 \pm 0.02^{b}(2)$ & $2.4 \pm 0.5^{a}(42)$ \\
\hline Histidine & $1.09 \pm 0.05^{c}$ & - & $0.75 \pm 0.05^{\mathrm{b}}(31)$ & $0.56 \pm 0.05^{a}(48)$ & $1.05 \pm 0.06^{b}$ & - & $0.76 \pm 0.09^{b}(28)$ & $0.77 \pm 0.10^{\mathrm{a}}(27)$ \\
\hline Tyrosine & $3.8 \pm 0.2^{c}$ & - & $2.65 \pm 0.03^{b}(31)$ & $1.62 \pm 0.15^{\mathrm{a}}(58)$ & $3.4 \pm 0.2^{b}$ & - & $3.059 \pm 0.005^{b}(10)$ & $1.9 \pm 0.3^{a}(43)$ \\
\hline Tryptophan & $1.56 \pm 0.05^{c}$ & - & $0.99 \pm 0.03^{b}(36)$ & $0.75 \pm 0.03^{a}(52)$ & $1.20 \pm 0.07^{b}$ & - & $1.08 \pm 0.04^{b}(10)$ & $0.90 \pm 0.08^{a}(25)$ \\
\hline Cystine & - & - & - & - & - & - & - & - \\
\hline
\end{tabular}

Data shown are mean values from triplicates and the standard deviation. Values in parentheses represent the percentage (\%) of reduction of elderly GI conditions (E1, E2 and E3) with respect to the control (C). ${ }^{\text {a-c }}$ Different lowercase letters indicate significant differences between models, with a significance level of $95 \%(p<0.05)$. 
Table 5.2.3. Amino acids profile ( $m g$ free amino acid / g product) of fresh and aged cheese digested under different in vitro digestion models (C: control; E1: Elderly 1; E2: Elderly 2; E3: Elderly 3) and reduction (\%) of amino acid released with respect to the control.

\begin{tabular}{|c|c|c|c|c|c|c|c|c|}
\hline \multirow{3}{*}{ Amino acid } & \multicolumn{7}{|c|}{$\begin{array}{c}\mathrm{mg} \text { free amino acid / g product } \\
\text { (Reduction with respect to the control (\%)) }\end{array}$} & \\
\hline & \multicolumn{4}{|c|}{ Fresh cheese } & \multicolumn{4}{|c|}{ Aged cheese } \\
\hline & C & E1 & E2 & E3 & $\mathrm{C}$ & E1 & E2 & E3 \\
\hline Alanine & $3.5 \pm 0.4^{c}$ & $2.8 \pm 0.2^{\mathrm{bc}}(20)$ & $2.3 \pm 0.6^{\mathrm{b}}(42)$ & $1.5 \pm 0.3^{\mathrm{a}}(55)$ & $4.391 \pm 0.106^{c}$ & $3.7 \pm 0.2^{b}(16)$ & $3.2 \pm 0.2^{\mathrm{b}}(27)$ & $\begin{array}{l}2.538 \pm 0.006^{a} \\
(42)\end{array}$ \\
\hline Glycine & $1.7 \pm 0.2^{\mathrm{c}}$ & $1.5 \pm 0.2^{\mathrm{bc}}(12)$ & $1.25 \pm 0.17^{\mathrm{b}}(28)$ & $0.51 \pm 0.10^{a}(72)$ & $2.6 \pm 0.6^{b}$ & $2.623 \pm 0.106^{b}(12)$ & $2.33 \pm 0.06^{\mathrm{b}}(22)$ & $0.96 \pm 0.07^{a}(68)$ \\
\hline Valine & $4.5 \pm 0.3^{b}$ & $4.2 \pm 0.3^{\mathrm{b}}(3)$ & $3.234 \pm 0.007^{a}(28)$ & $2.96 \pm 0.10^{a}(34)$ & $7.9 \pm 0.5^{b}$ & $7.08 \pm 0.07^{\mathrm{ab}}(10)$ & $6.24 \pm 0.05^{a}(21)$ & $6.3 \pm 0.4^{\mathrm{a}}(19)$ \\
\hline Leucine & $11.6 \pm 0.9^{b}$ & $10.96 \pm 0.10^{b}(6)$ & $8.9 \pm 0.2^{\mathrm{a}}(24)$ & $9.0 \pm 0.3^{a}(25)$ & $16.765 \pm 1.108^{b}$ & $14.1 \pm 0.2^{\mathrm{a}}(16)$ & $14.79 \pm 0.12^{\mathrm{a}}(12)$ & $13.8 \pm 0.5^{a}(18)$ \\
\hline Isoleucine & $2.55 \pm 0.18^{c}$ & $2.16 \pm 0.18^{b}(19)$ & $1.722 \pm 0.106^{\mathrm{a}}(33)$ & $1.58 \pm 0.09^{a}(38)$ & $4.78 \pm 0.12^{c}$ & $4.1 \pm 0.2^{\mathrm{ab}}(14)$ & $4.19 \pm 0.03^{b}(12)$ & $3.83 \pm 0.17^{a}(20)$ \\
\hline Threonine & $2.45 \pm 0.18^{b}$ & $1.5 \pm 0.4^{\mathrm{a}}(30)$ & $1.31 \pm 0.03^{\mathrm{a}}(46)$ & $1.18 \pm 0.06^{a}(52)$ & $3.5 \pm 0.3^{b}$ & $2.8 \pm 0.2^{\mathrm{a}}(19)$ & $2.78 \pm 0.16^{a}(20)$ & $2.33 \pm 0.17^{a}(33)$ \\
\hline Serine & $3.2 \pm 0.5^{c}$ & $2.09 \pm 0.09^{b}(35)$ & $1.77 \pm 0.17^{\mathrm{ab}}(45)$ & $1.59 \pm 0.15^{\mathrm{a}}(53)$ & $4.584 \pm 0.017^{c}$ & $3.9 \pm 0.2^{\mathrm{bc}}(14)$ & $3.3 \pm 0.3^{\mathrm{ab}}(27)$ & $3.1 \pm 0.4^{a}(33)$ \\
\hline Proline & $1.06 \pm 0.17^{c}$ & $0.85 \pm 0.06^{b}(23)$ & $0.68 \pm 0.05^{\mathrm{ab}}(29)$ & $0.51 \pm 0.03^{a}(52)$ & $3.47 \pm 0.09^{c}$ & $2.96 \pm 0.17^{b}(15)$ & $2.3 \pm 0.2^{\mathrm{a}}(34)$ & $2.41 \pm 0.13^{\mathrm{a}}(34)$ \\
\hline Asparagine & $1.67 \pm 0.03^{b}$ & $1.53 \pm 0.03^{b}(9)$ & $0.61 \pm 0.17^{a}(59)$ & $0.597 \pm 0.008^{a}(64)$ & $3.6 \pm 0.6^{c}$ & $2.77 \pm 0.14^{b}(22)$ & $1.97 \pm 0.06^{a}(45)$ & $1.82 \pm 0.17^{\mathrm{a}}(19)$ \\
\hline Aspartic acid & $1.9 \pm 0.2^{c}$ & $1.87 \pm 0.09^{c}(6)$ & $1.26 \pm 0.14^{b}(38)$ & $0.815 \pm 0.004^{a}(58)$ & $3.6 \pm 0.3^{b}$ & $3.16 \pm 0.04^{b}(13)$ & $2.24 \pm 0.04^{\mathrm{a}}(38)$ & $2.0 \pm 0.2^{\mathrm{a}}(45)$ \\
\hline Methionine & $2.35 \pm 0.19^{c}$ & $1.93 \pm 0.10^{b}(18)$ & $1.47 \pm 0.02^{\mathrm{a}}(38)$ & $1.45 \pm 0.06^{a}(38)$ & $3.69 \pm 0.07^{c}$ & $3.24 \pm 0.13^{b}(12)$ & $3.07 \pm 0.09^{\mathrm{ab}}(17)$ & $2.94 \pm 0.07^{a}(20)$ \\
\hline Glutamic acid & $3.8 \pm 0.2^{b}$ & $3.47 \pm 0.13^{b}(6)$ & $3.49 \pm 0.18^{b}(10)$ & $2.85 \pm 0.13^{\mathrm{a}}(24)$ & $5.9 \pm 0.2^{c}$ & $4.78 \pm 0.06^{b}(19)$ & $5.22 \pm 0.01^{\mathrm{ab}(11)}$ & $4.2 \pm 0.4^{\mathrm{a}}(28)$ \\
\hline Phenylalanine & $7.9 \pm 0.5^{c}$ & $6.2 \pm 0.4^{b}(23)$ & $5.38 \pm 0.17^{a}(32)$ & $5.00 \pm 0.15^{a}(36)$ & $14.15 \pm 0.06^{d}$ & $11.52 \pm 0.09^{c}(19)$ & $9.7 \pm 0.2^{b}(32)$ & $7.6 \pm 0.2^{\mathrm{a}}(46)$ \\
\hline Glutamine & $6.2 \pm 1.4^{a}$ & $5.0 \pm 0.5^{\mathrm{a}}(15)$ & $4.8 \pm 0.7^{a}(28)$ & $5.0 \pm 0.3^{a}(22)$ & $10.5 \pm 0.7^{b}$ & $8.0 \pm 0.8^{a}(24)$ & $7.1 \pm 0.2^{\mathrm{a}}(32)$ & $6.9 \pm 1.0^{\mathrm{a}}(34)$ \\
\hline Ornithine & - & - & - & - & $0.970 \pm 0.008^{c}$ & $0.85 \pm 0.03^{b}(13)$ & $0.51 \pm 0.04^{a}(47)$ & $-(100)$ \\
\hline Lysine & $10.7 \pm 0.3^{a}$ & $9 \pm 2^{\mathrm{a}}(4)$ & $9.5 \pm 0.7^{\mathrm{a}}(15)$ & $9.2 \pm 0.9^{a}(19)$ & $17.9 \pm 0.4^{b}$ & $13.85 \pm 0.14^{\mathrm{a}}(23)$ & $13.7 \pm 1.0^{\mathrm{a}}(21)$ & $12.8 \pm 1.0^{\mathrm{a}}$ \\
\hline Histidine & $2.1 \pm 0.3^{b}$ & $1.68 \pm 0.15^{\mathrm{a}}(15)$ & $1.74 \pm 0.15^{\mathrm{ab}}(20)$ & $1.57 \pm 0.14^{\mathrm{a}}(24)$ & $3.29 \pm 0.03^{c}$ & $2.72 \pm 0.02^{\mathrm{ab}}(17)$ & $2.91 \pm 0.13^{\mathrm{bc}}(11)$ & $2.4 \pm 0.3^{a}$ \\
\hline Tyrosine & $9.19 \pm 0.04^{b}$ & $8.5 \pm 0.3^{b}(8)$ & $7.2 \pm 0.6^{a}(25)$ & $6.4 \pm 1.0^{\mathrm{a}}(36)$ & $11.1 \pm 0.7^{d}$ & $9.2 \pm 0.3^{c}(17)$ & $8.0 \pm 0.3^{b}(28)$ & $5.2 \pm 0.4^{a}$ \\
\hline Tryptophan & $4.5 \pm 0.6^{b}$ & $3.5 \pm 0.3^{\mathrm{a}}(25)$ & $3.30 \pm 0.07^{a}(26)$ & $2.90 \pm 0.14^{a}(35)$ & $5.62 \pm 0.07^{d}$ & $4.7 \pm 0.3^{b}(16)$ & $4.70 \pm 0.02^{\mathrm{b}}(16)$ & $3.45 \pm 0.10^{\mathrm{a}}$ \\
\hline Cystine & $2.42 \pm 0.08^{b}$ & $2.12 \pm 0.04^{a}(12)$ & $2.13 \pm 0.06^{\mathrm{a}}(12)$ & $-(100)$ & $2.8 \pm 0.3^{c}$ & $2.16 \pm 0.06^{b}(23)$ & $1.54 \pm 0.05^{\mathrm{a}}(45)$ & $-(100)$ \\
\hline
\end{tabular}

Data shown are mean values from triplicates and the standard deviation. Values in parentheses represent the percentage (\%) of reduction of elderly GI conditions (E1, E2 and E3) with respect to the control (C). ${ }^{\text {a-c }}$ Different lowercase letters indicate significant differences between models, with a significance level of $95 \%(p<0.05)$. 
Table 5.2.4. Molar percentages of acyl groups (AG) supported on the different glyceryl backbone structures ( $T G, 1,2-D G, 1,3-D G, 2-M G, 1-M G)$ and free fatty acids (FFA), present in the non-digested (ND) and in vitro digested samples (C: Control; E1: Elderly 1; E2: Elderly 2; E3: Elderly 3) of fresh and aged cheese.

\begin{tabular}{|c|c|c|c|c|c|c|c|}
\hline & $\begin{array}{l}\text { In vitro digestion } \\
\text { model }\end{array}$ & $\mathrm{AG}_{\mathrm{TG}}(\%)$ & $\mathrm{AG}_{1,2-\mathrm{DG}}(\%)$ & $\mathrm{AG}_{1,3-\mathrm{DG}}(\%)$ & $\mathrm{AG}_{2-\mathrm{MG}}(\%)$ & $\mathrm{AG}_{1-\mathrm{MG}}(\%)$ & FFA (\%) \\
\hline $\begin{array}{l}\begin{array}{l}\text { Fresh } \\
\text { cheese }\end{array} \\
\text { che }\end{array}$ & $\begin{array}{c}\text { Non digested } \\
\mathrm{C}\end{array}$ & $\begin{array}{c}97.84 \pm 0.12^{\mathrm{c}} \\
11.09 \pm\end{array}$ & $1.3 \pm 0.3^{\mathrm{a}}$ & $=1.16 \pm 0.14^{c}$ & $0 \pm 0^{a}$ & $0 \pm 0^{\mathrm{a}}$ & $0.4 \pm 0.3^{a}$ \\
\hline \multirow{4}{*}{ cheese } & & $1.14^{\mathrm{ab}}$ & $10.0 \pm 0.8^{b}$ & $0.96 \pm 0.02^{\mathrm{d}}$ & $6.36 \pm 0.15^{d}$ & $1.85 \pm 0.06^{b}$ & $69.8 \pm 0.6^{b}$ \\
\hline & E1 & $12 \pm 3^{a b}$ & $8.2 \pm 0.7^{b}$ & $0.30 \pm 0.10^{\mathrm{b}}$ & $6.9 \pm 0.6^{c}$ & $2.1 \pm 0.3^{b}$ & $71 \pm 3^{b}$ \\
\hline & E2 & $13.3 \pm 0.9^{b}$ & $8.3 \pm 1.5^{b}$ & $0.10 \pm 0.19^{a}$ & $6.7 \pm 0.2^{c}$ & $2.1 \pm 0.4^{b}$ & $69.7 \pm 0.7^{b}$ \\
\hline & E3 & $8.40 \pm 0.10^{a}$ & $8.65 \pm 0.16^{b}$ & $0.62 \pm 0.04^{b}$ & $4.29 \pm 0.05^{b}$ & $1.84 \pm 0.01^{b}$ & $76.2 \pm 0.3^{c}$ \\
\hline Aged & Non digested & $98.1 \pm 0.7^{c}$ & $1.3 \pm 0.4^{\mathrm{a}}$ & $1.15 \pm 0.12^{\mathrm{b}}$ & $0 \pm 0^{\mathrm{a}}$ & $0 \pm 0^{\mathrm{a}}$ & $0.5 \pm 0.2^{\mathrm{a}}$ \\
\hline \multirow[t]{4}{*}{ cheese } & $\mathrm{C}$ & $18 \pm 4^{b}$ & $8 \pm 2^{b}$ & $0.3 \pm 0.3^{a}$ & $7.8 \pm 0.9^{d}$ & $3.1 \pm 0.3^{b}$ & $62.8 \pm 0.5^{b}$ \\
\hline & E1 & $10 \pm 2^{\mathrm{a}}$ & $8 \pm 3^{b}$ & $0.4 \pm 0.7^{\mathrm{ab}}$ & $9.8 \pm 0.4^{e}$ & $3.5 \pm 0.9^{b}$ & $67.99 \pm 0.19^{c}$ \\
\hline & E2 & $6.7 \pm 1.4^{a}$ & $6.9 \pm 0.9^{b}$ & $1.1 \pm 0.5^{\mathrm{ab}}$ & $6.2 \pm 0.3^{c}$ & $2.8 \pm 0.7^{b}$ & $76 \pm 4^{d}$ \\
\hline & E3 & $7.06 \pm 0.19^{\mathrm{a}}$ & $5.3 \pm 0.2^{b}$ & $1.14 \pm 0.04^{\mathrm{ab}}$ & $3.35 \pm 0.13^{b}$ & $2.43 \pm 0.16^{b}$ & $80.7 \pm 0.8^{e}$ \\
\hline
\end{tabular}

Data shown are mean values from triplicates and the standard deviation. ${ }^{*}$ AG: acyl groups. ${ }^{\text {a-d }}$ different lowercase letters means significant difference between models $(p<0.05)$. 
conditions (E3) than under control ones. The decreased pancreatic lipases and biliar concentration in this model compared to control one, would not negatively affect the lipid digestibility because it is compensates by the longer intestinal time ${ }^{45}$. Therefore, the increase of intestinal residence time under model E3 would be the responsible of the greater lipid hydrolysis achieved under these digestive conditions ${ }^{46}$.

\section{Lactose release, calcium, vitamins $A$ and D3 bioaccessibility under elderly GI conditions}

A reduced digestion of macronutrients, such as proteins and lipids, could be coupled to a deficient release and solubilization of micronutrients and/or lactose. Figure 5.2.3 shows lactose (mg glucose eq./g product), calcium (mg $\mathrm{Ca} / \mathrm{g}$ product), vitamin A ( $\mu$ g retinol/g product) and D3 ( $\mu \mathrm{g}$ cholecalciferol/g product) contents in the bioaccessible fraction as well as their bioaccessibility (\%) (at the bottom of the bars) with respect of the initial content of each nutrient. Lactose content in the bioaccessible fraction ranged from 4 to $20 \mathrm{mg}$ glucose eq./ g product for milk and aged cheese, respectively under the $\mathrm{C}$ digestive conditions. In terms of bioaccesibility (\%), lactose from yogurt and aged cheese, compared to milk and fresh cheese, presented the highest values regardless the GI conditions. Regarding the effect of elderly $\mathrm{GI}$ conditions on lactose released, no statistically significant differences were found in the digesta of yogurt, fresh and aged cheeses, even if the oral, gastric and intestinal were altered. Only elderly GI conditions seemed to negatively the lactose release from milk, which possess the highest lactose content among the studied dairy products. In fact, it exists a lack of data related to the lactose release during luminal digestion process to support this behavior, even if it seems to be related to structural matrix of the product. Wang et al. (2018) ${ }^{47}$ reported that casein coagulation in dairy matrices might generate a complex matrix that affect 
the enzyme cleavage site and nutrients releasing, such as lactose. However, Figure 5.2.3 shows higher bioaccessibility from certain solid matrices such as aged cheese than from liquid matrices as milk. This fact could be related to the acidic coagulation experimented by milk at stomach and thus, resulting also in a semi-solid matrix.
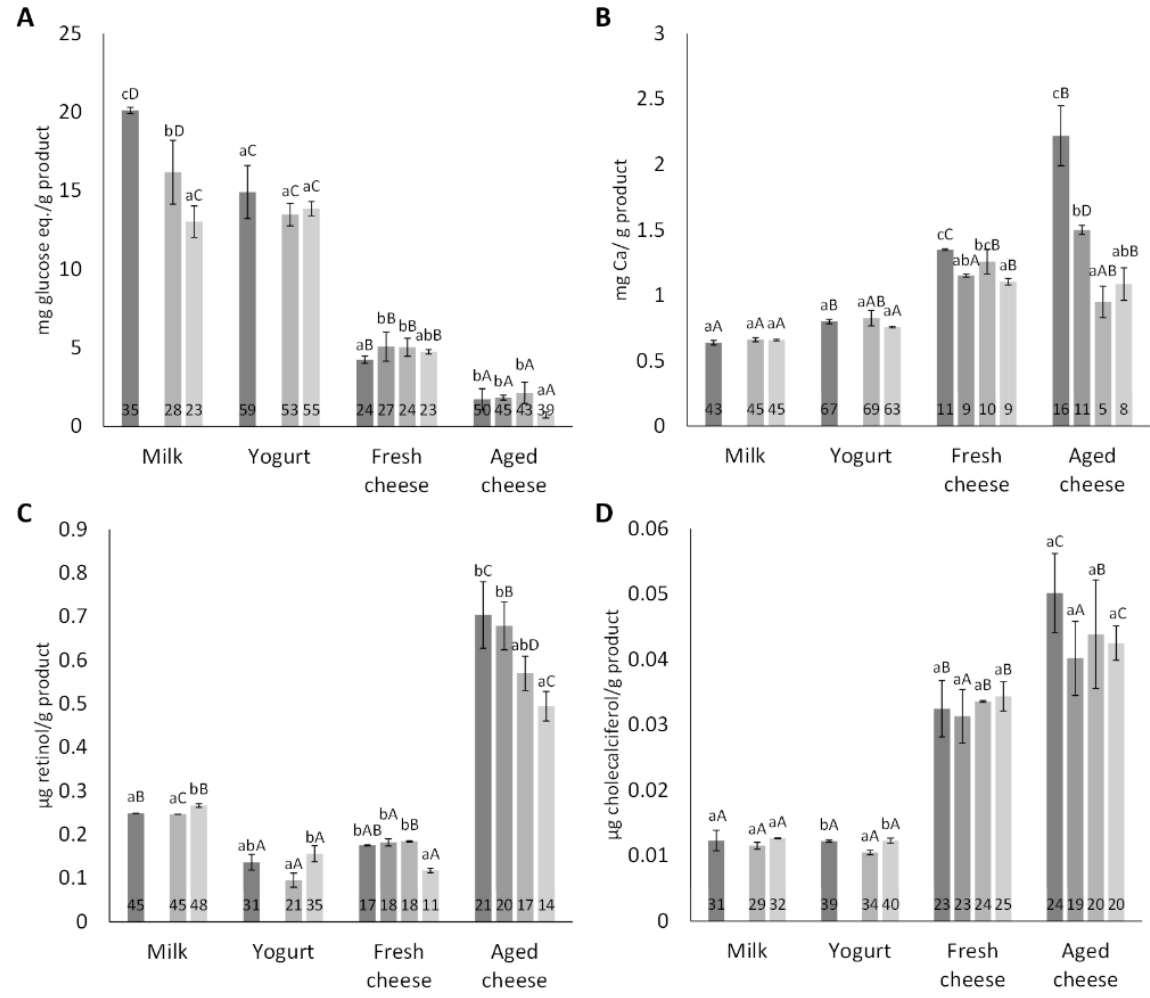

$$
\square \mathrm{C} \backsim \mathrm{E} 1 \backsim \mathrm{E} 2 \square \mathrm{E} 3
$$

Figure 5.2.3. A) Lactose (mg glucose eq./g product) and B) calcium ( $\mathrm{mg} \mathrm{Ca} / \mathrm{g}$ product), C) vitamin $A$ ( $\mu$ g retinol/g product) and $D)$ vitamin $D 3(\mu g$ cholecalciferol/g product) content in the bioaccessible fraction from milk, yogurt, fresh cheese and aged cheese digested under different in vitro 
digestion models (C: Control; E1: Elderly 1; E2: Elderly 2; E3: Elderly 3). Values at the bottom of the bars represents bioaccessibility (\%) with respect to the nutrient content in the product before in vitro digestion. a-c different lowercase letters indicate significant differences between models $(p<0.05)$. $A-D$ different capital letters indicate significant differences between products $(p<0.05)$.

Calcium content in the bioaccessible fraction ranged from 0.6 to $2.1 \mathrm{mg} \mathrm{Ca} / \mathrm{g}$ product in milk and aged cheese, respectively, under standard conditions of digestion (C). The bioaccessibility (\%), however, was much higher in milk (43\%), and especially in yogurt (67\%), than in cheeses (11 and 16\% for fresh and aged). In fact, Lorieau et al. (2018) $)^{48}$ reports greater calcium bioaccessibility in liquid matrices than in gel structured matrices. The higher bioaccessibility of calcium in yogurt than milk could be attributed to some dietary factors related to casein phosphopeptides (CPP), carbohydrates, Maillard reaction products, among others. Casein phosphopetides resulting from the enzymatic hydrolysis of caseins, can effectively bind calcium and inhibit formation of insoluble calcium phosphates ${ }^{49}$. Yogurt present more CPP than milk due to the alteration in their micelle structure obtained during processing ${ }^{50}$. Even if cheeses present lower bioaccessibility, aged cheese remains the highest supplier of bioaccessible calcium. On the other hand, no elderly Gl alterations seem to highly compromise the release and solubilization of this mineral from dairy products, with the exception of from aged cheese. Even though, both cheeses remain an excellent source of bioaccessible calcium for lactase-deficient subjects such as most of elderly people, considering the calcium content ( $\mathrm{mg}$ of $\mathrm{Ca} / \mathrm{g}$ of product) reported even under the worst $\mathrm{Gl}$ conditions (E3). Diet recommendations addressed to elderly advice an increase of calcium intake, since bone density decreases with ageing, which can lead to osteopenia and, in extreme cases, osteoporosis, which is partly related to the consumption of dietary calcium ${ }^{6}$. The latter is a significant health problem that contributes to disability and 
premature mortality among women and older men. Although genetic factors influence maximum bone mass, diet together with an active life style are clearly two of the modifiable risk factors for osteoporosis ${ }^{41}$.

Besides, vitamin A bioaccessibility (\%) varied between 17 and $45 \%$ under control GI conditions (C); while vitamin D3 bioaccessibility did from 24 and $39 \%$ under the same Gl model (Figure 5.2.3), milk being the most advantageous matrix for vitamins release and cheeses the least. However, the liposoluble vitamins content in the bioaccessible fraction of digested aged cheese is noticeable superior to other matrices. The differences in terms of release, solubilization and micellar incorporation of these vitamins among milk and dairy products could be attributed to the food matrix. Thus, it is found that when structured food matrices are more complex the minor the fat-soluble vitamins bioaccessibility ${ }^{51}$. In fact, vitamins A and D3 exhibited the highest bioaccessibility in yogurt and milk, but lower net supply of these nutrients in their bioaccessible form, compared to cheeses, and specially aged one.

It is reported that digestion and absorption of the fat-soluble vitamins basically follow the same path as lipids ${ }^{41}$. However, it was observed in none of the cheeses. In these cases, vitamins $A$ and $D$ - experimented a significant reduction under E3; while fat digestibility was not affected. The suboptimal bile salts concentration given in E3 model could be, however, responsible of vitamins bioaccessibility detriment. Liposoluble vitamins are dependent on solubilization by bile acids, and an alteration in bile flow results in maldigestion and malabsorption ${ }^{52}$.

\section{Descriptive relationship among the digestion end-products}

A PCA was conducted to evaluate the global relationship between products of digestion in the dairy products from a descriptive point of view. Figure 5.2.4 illustrates the loadings for the different products of the digestion 
(proteolysis, lipolysis, lactose release, calcium, vitamin D3 and A bioaccessibilities) as well as the scores of the different dairy products (milk, yogurt, fresh and aged cheese) under the different simulated GI conditions (C, E1, E2 and E3). The first two principal components of the analyses explain $77.264 \%$ of the total variance of the percentage of macronutrient extents and percentage of micronutrients bioaccessibility of the samples (PC1: $58.813 \%$ and PC2: $18.451 \%)$. In the score plot, proximity between samples indicates similar behavior in terms of digestibility. PC1 (59\%) clearly differentiates between liquid and semi-liquid products (milk and yogurt), located at the right side of the plot, and solids ones (cheeses), located at the left side of the plot. Besides, PCA shows the narrow relationship between proteolysis, bioaccessibility of calcium and vitamin D3; while PC2 seems to distinguish yogurt and aged cheese from milk and fresh cheese in terms of vitamin A bioaccessibility (higher in milk than in the other matrices) and lactose release (higher in yogurt and aged cheese than in milk or fresh cheese). 


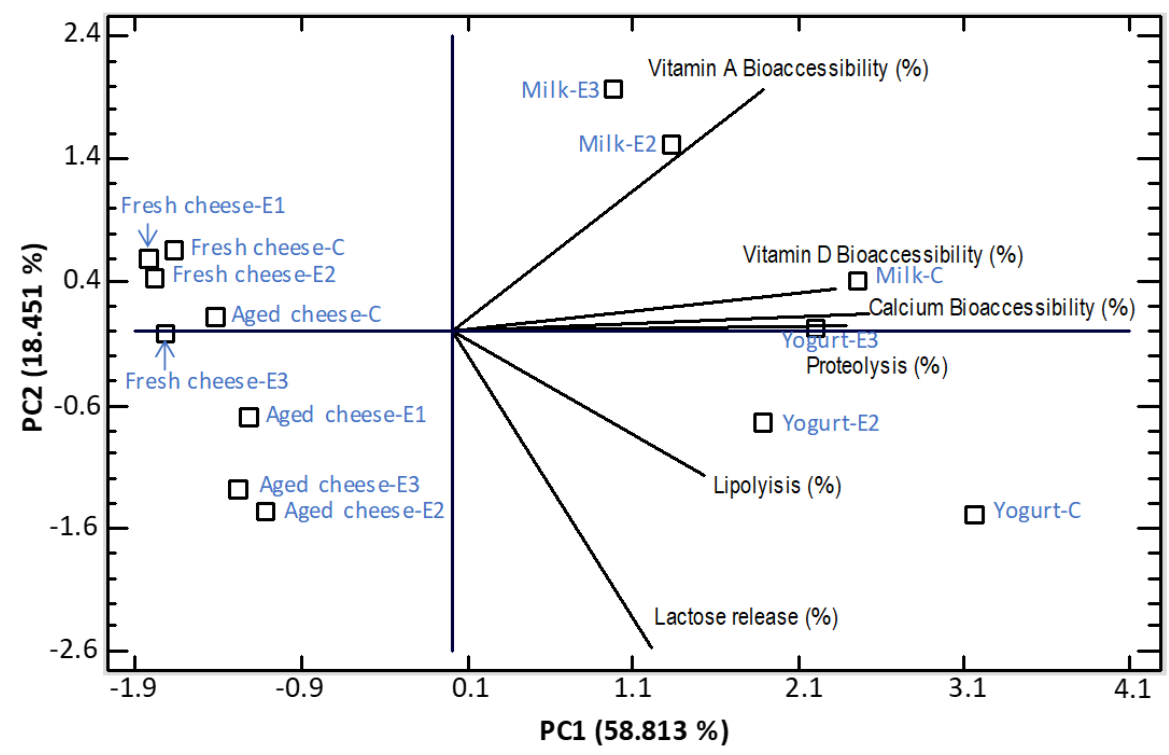

Figure 5.2.4. Biplot of the different end-product resulting from digestion and their relationship with the binomial dairy product (milk, yogurt, fresh or aged cheese)-GI conditions (C: Control; E1: Elderly 1; E2: Elderly 2; E3: Elderly 3) obtained by means of the principal components analysis (PCA).

\section{CONCLUSIONS}

This study contributes to a better understanding of dairy products (milk, yogurt, fresh and aged cheese) digestibility under elderly gastrointestinal conditions and depending on food matrix characteristics. The results report that proteolysis extent highly depends on the structural matrix of dairy products, ranging from 50 to $100 \%$ under healthy gastrointestinal conditions (control) for cheeses and milk and yogurt, respectively. GI alterations appearing with ageing negatively affect the digestibility of dairy proteins with a reduction around $50 \%$, compared proteolysis extent obtained under control conditions. A notable decrease of some essential 
amino acids release such as leucine, isoleucine, valine and tryptophan was also noticed under elderly GI conditions. Nevertheless, absorbable fraction and lipolysis extent of cheeses seems to be enhanced by the longer duodenal transit time given of elderly digestion. Finally, calcium, vitamin D3 and proteolysis extent seems to be positively associated, especially in milk and yogurt matrices. Liquid and semi-liquid matrices favor micronutrients release in a greater extent to solid-matrices; however, the net supply of calcium, vitamins A and D3 in their bioaccessible form (per g of product) is greater in cheeses than milk or yogurt.

Therefore, the obtained results could be useful to establish accurate dietetic recommendations addressed to elderly with regards to dairy products consumption for elderly. 


\section{REFERENCES}

(1) Chollet, M.; Gille, D.; Piccinali, P.; Bütikofer, U.; Schmid, A.; Stoffers, H.; Altintzoglou, T.; Walther, B. Short Communication: DAIRY Consumption among Middle-Aged and Elderly Adults in Switzerland. Journal of Dairy Science 2014, 97 (9), 5387-5392. https://doi.org/10.3168/jds.2014-8193.

(2) United Nations. Department of International Economic and Social Affairs. Population Division. World Population Ageing 2015 (ST/ESA/SER. A/390).

(3) Volkert, D.; Beck, A. M.; Cederholm, T.; Cruz-Jentoft, A.; Goisser, S.; Hooper, L.; Kiesswetter, E.; Maggio, M.; Raynaud-Simon, A.; Sieber, C. C.; Sobotka, L.; Van Asselt, D.; Wirth, R.; Bischoff, S. C. ESPEN Guideline ESPEN Guideline on Clinical Nutrition and Hydration in Geriatrics. 2018. https://doi.org/10.1016/j.clnu.2018.05.024.

(4) Morley, J. E. Frailty and Sarcopenia: The New Geriatric Giants. Revista de investigacion clinica 2016, 68 (2), 59-67.

(5) Dehghan, M.; Mente, A.; Rangarajan, S.; Sheridan, P.; Mohan, V.; Iqbal, R.; Gupta, R.; Lear, S.; Wentzel-Viljoen, E.; Avezum, A.; LopezJaramillo, P.; Mony, P.; Varma, R. P.; Kumar, R.; Chifamba, J.; Alhabib, K. F.; Mohammadifard, N.; Oguz, A.; Lanas, F.; Rozanska, D.; Bostrom, K. B.; Yusoff, K.; Tsolkile, L. P.; Dans, A.; Yusufali, A. H.; Orlandini, A.; Poirier, P.; Khatib, R.; Hu, B.; Wei, L.; Yin, L.; Deeraili, A.; Yeates, K.; Yusuf, R.; Ismail, N.; Mozaffarian, D.; Teo, K.; Anand, S. S.; Yusuf, S. Association of Dairy Intake with Cardiovascular Disease and Mortality in 21 Countries from Five Continents (PURE): A Prospective Cohort Study. The Lancet 2018, 392 (10161), 2288-2297. https://doi.org/10.1016/S0140-6736(18)31812-9.

(6) McCabe, L. D.; Martin, B. R.; McCabe, G. P.; Johnston, C. C.; Weaver, C. M.; Peacock, M. Dairy Intakes Affect Bone Density in the Elderly. The American journal of clinical nutrition 2004, 80 (4), 1066-1074. 
https://doi.org/10.1093/ajcn/80.4.1066.

(7) Rashid, I.; Tiwari, P.; Lehl, S. S. Malnutrition among Elderly a Multifactorial Condition to Flourish: Evidence from a Cross-Sectional Study. Clinical Epidemiology and Global Health 2019.

(8) Nagler, R. M.; Hershkovich, O. Age-Related Changes in Unstimulated Salivary Function and Composition and Its Relations to Medications and Oral Sensorial Complaints. Aging Clinical and Experimental Research 2005, 17 (5), 358-366. https://doi.org/10.1007/BF03324623.

(9) Salles, N. Basic Mechanisms of the Aging Gastrointestinal Tract. Digestive Diseases 2007, 25 (2), 112-117. https://doi.org/10.1159/000099474.

(10) Shani-Levi, C.; Alvito, P.; Andrés, A.; Assunção, R.; Barberá, R.; Blanquet-Diot, S.; Bourlieu, C.; Brodkorb, A.; Cilla, A.; Deglaire, A.; Denis, S.; Dupont, D.; Heredia, A.; Karakaya, S.; Giosafatto, C. V. L.; Mariniello, L.; Martins, C.; Ménard, O.; El, S. N.; Vegarud, G. E.; Ulleberg, E.; Lesmes, U. Extending in Vitro Digestion Models to Specific Human Populations: Perspectives, Practical Tools and BioRelevant Information. Trends in Food Science and Technology. Elsevier February 1, 2017, pp 52-63. https://doi.org/10.1016/j.tifs.2016.10.017.

(11) AOAC. Official Methods of Análisis. Association of Official Analytical Chemists. 15th Edition. 2000.

(12) ISO; IDF. Milk - Determination of Fat Content - Gravimetric Method (Reference Method). BS EN ISO 1211:2010. 2010.

(13) Armellini, R.; Peinado, I.; Asensio-Grau, A.; Pittia, P.; Scampicchio, M.; Heredia, A.; Andres, A. In Vitro Starch Digestibility and Fate of Crocins in Pasta Enriched with Saffron Extract. Food Chemistry 2019, 283, 155-163. https://doi.org/10.1016/j.foodchem.2019.01.041. 
(14) Noël, L.; Carl, M.; Vastel, C.; Guérin, T. Determination of Sodium, Potassium, Calcium and Magnesium Content in Milk Products by Flame Atomic Absorption Spectrometry (FAAS): A Joint ISO/IDF Collaborative Study. International Dairy Journal 2008, 18 (9), 899904. https://doi.org/10.1016/j.idairyj.2008.01.003.

(15) Castaneda, N.; Lee, Y. Microstructure of a Model Fresh Cheese and Bioaccessibility of Vitamin D3 Using in Vitro Digestion. Gels 2019, 5 (1). https://doi.org/10.3390/gels5010016.

(16) Nieva-Echevarría, B.; Goicoechea, E.; Manzanos, M. J.; Guillén, M. D. A Study by $1 \mathrm{H}$ NMR on the Influence of Some Factors Affecting Lipid in Vitro Digestion. Food Chemistry 2016, 211, 17-26. https://doi.org/10.1016/J.FOODCHEM.2016.05.021.

(17) Minekus, M.; Alminger, M.; Alvito, P.; Ballance, S.; Bohn, T.; Bourlieu, C.; Carrière, F.; Boutrou, R.; Corredig, M.; Dupont, D.; Dufour, C.; Egger, L.; Golding, M.; Karakaya, S.; Kirkhus, B.; Le Feunteun, S.; Lesmes, U.; Maclerzanka, A.; MacKie, A.; Marze, S.; McClements, D. J.; Ménard, O.; Recio, I.; Santos, C. N.; Singh, R. P.; Vegarud, G. E.; Wickham, M. S. J.; Weitschies, W.; Brodkorb, A. A Standardised Static in Vitro Digestion Method Suitable for Food-an International Consensus. Food and Function 2014, 5 (6), 1113-1124. https://doi.org/10.1039/c3fo60702j.

(18) Peyron, M. A.; Santé-Lhoutellier, V.; François, O.; Hennequin, M. Oral Declines and Mastication Deficiencies Cause Alteration of Food Bolus Properties. Food and Function 2018, 9 (2), 1112-1122. https://doi.org/10.1039/c7fo01628j.

(19) Chen, J.; Lolivret, L. The Determining Role of Bolus Rheology in Triggering a Swallowing. Food Hydrocolloids 2011, 25 (3), 325-332. https://doi.org/10.1016/j.foodhyd.2010.06.010.

(20) Le Révérend, B.; Saucy, F.; Moser, M.; Loret, C. Adaptation of Mastication Mechanics and Eating Behaviour to Small Differences in 
Food Texture. Physiology and Behavior 2016, 165, 136-145. https://doi.org/10.1016/j.physbeh.2016.07.010.

(21) Woda, A.; Foster, K.; Mishellany, A.; Peyron, M. A. Adaptation of Healthy Mastication to Factors Pertaining to the Individual or to the Food. Physiology and Behavior 2006, 89 (1), 28-35. https://doi.org/10.1016/j.physbeh.2006.02.013.

(22) Jalabert-Malbos, M. L.; Mishellany-Dutour, A.; Woda, A.; Peyron, M. A. Particle Size Distribution in the Food Bolus after Mastication of Natural Foods. Food Quality and Preference 2007, 18 (5), 803-812. https://doi.org/10.1016/j.foodqual.2007.01.010.

(23) Hernández-Olivas, E.; Muñoz-Pina, S.; Andrés, A.; Heredia, A. Impact of Elderly Gastrointestinal Alterations on in Vitro Digestion of Salmon, Sardine, Sea Bass and Hake: Proteolysis, Lipolysis and Bioaccesibility of Calcium and Vitamins. Food Chemistry 2020, 326. https://doi.org/10.1016/j.foodchem.2020.127024.

(24) Lee, J. S.; Weyant, R. J.; Corby, P.; Kritchevsky, S. B.; Harris, T. B.; Rooks, R.; Rubin, S. M.; Newman, A. B. Edentulism and Nutritional Status in a Biracial Sample of Well-Functioning, Community-Dwelling Elderly: The Health, Aging, and Body Composition Study. American Journal of Clinical Nutrition 2004, 79 (2), 295-302. https://doi.org/10.1093/ajcn/79.2.295.

(25) O'Keeffe, M.; Kelly, M.; O’Herlihy, E.; O’Toole, P. W.; Kearney, P. M.; Timmons, S.; O'Shea, E.; Stanton, C.; Hickson, M.; Rolland, Y.; Sulmont Rossé, C.; Issanchou, S.; Maitre, I.; Stelmach-Mardas, M.; Nagel, G.; Flechtner-Mors, M.; Wolters, M.; Hebestreit, A.; De Groot, L. C. P. G. M.; van de Rest, O.; Teh, R.; Peyron, M. A.; Dardevet, D.; Papet, I.; Schindler, K.; Streicher, M.; Torbahn, G.; Kiesswetter, E.; Visser, M.; Volkert, D.; O'Connor, E. M. Potentially Modifiable Determinants of Malnutrition in Older Adults: A Systematic Review. Clinical Nutrition. Churchill Livingstone December 1, 2019, pp 24772498. https://doi.org/10.1016/j.clnu.2018.12.007. 
(26) Peinado, I.; Koutsidis, G.; Ames, J. Production of Seafood Flavour Formulations from Enzymatic Hydrolysates of Fish By-Products. LWT - Food Science and Technology 2016, 66, 444-452. https://doi.org/10.1016/j.lwt.2015.09.025.

(27) Rinaldi, L.; Gauthier, S. F.; Britten, M.; Turgeon, S. L. Invitro Gastrointestinal Digestion of Liquid and Semi-Liquid Dairy Matrixes. LWT - Food Science and Technology 2014, 57 (1), 99-105. https://doi.org/10.1016/j.lwt.2014.01.026.

(28) Mulet, A.; Escriche, I.; Rossello, C.; Tarrazó, J. Changes in the Volatile Fraction during Ripening of Mahon Cheese. Food Chemistry 1999, 65 (2), 219-225. https://doi.org/10.1016/S0308-8146(98)00209-X.

(29) Delgado, D.; Salazar, G.; García, M. Sequential Optimisation of Yield and Sensory Quality of Semi-Hard Cheese Manufactured from a Mixture of Ultrafiltered Ewes' and Cows' Milk. International Dairy Journal 2013, $32 \quad$ (2), 89-98. https://doi.org/10.1016/j.idairyj.2013.04.008.

(30) Diana, M.; Rafecas, M.; Arco, C.; Quílez, J. Free Amino Acid Profile of Spanish Artisanal Cheeses: Importance of Gamma-Aminobutyric Acid (GABA) and Ornithine Content. Journal of Food Composition and Analysis 2014, 35

(2), 94-100. https://doi.org/10.1016/j.jfca.2014.06.007.

(31) AESAN/BEDCA. Base de Datos Española de Composición de Alimentos v1.0 https://www.bedca.net/bdpub/index.php.

(32) Segarra, P. J. S. Composición de Quesos Artesanos Españoles: Constituyentes Inorgánicos. Universidad de Córdoba 1999.

(33) Harju, M.; Kallioinen, H.; Tossavainen, O. Lactose Hydrolysis and Other Conversions in Dairy Products: Technological Aspects. International Dairy Journal. Elsevier February 1, 2012, pp 104-109. https://doi.org/10.1016/j.idairyj.2011.09.011. 
(34) Asensio-Grau, A.; Peinado, I.; Heredia, A.; Andrés, A. In Vitro Study of Cheese Digestion: Effect of Type of Cheese and Intestinal Conditions on Macronutrients Digestibility. LWT 2019, 113, 108278. https://doi.org/10.1016/j.Iwt.2019.108278.

(35) McSweeney, P. L. H. Biochemistry of Cheese Ripening. In International Journal of Dairy Technology; John Wiley \& Sons, Ltd, 2004; Vol. 57, pp 127-144. https://doi.org/10.1111/j.14710307.2004.00147.x.

(36) García-Palmer, F. J.; Serra, N.; Palou, A.; Gianotti, M. Free Amino Acids as Indices of Mahón Cheese Ripening. Journal of Dairy Science 1997, 80 (9), 1908-1917. https://doi.org/10.3168/jds.S00220302(97)76131-9.

(37) Kastberg, K.; Fergal, M.; Rattray, P.; Høier, E.; Ardö, Y.; Møller, K. K.; Ardö, Y.; Rattray, F. P.; Høier, E.; Hansen, C. Erratum to: Manufacture and Biochemical Characteristics during Ripening of Cheddar Cheese with Variable $\mathrm{NaCl}$ and Equal Moisture Content. Dairy Sci. \& Technol 2012, 92, 541-542. https://doi.org/10.1007/s13594-012-0076-3.

(38) Maldonado-Valderrama, J.; Wilde, P.; Maclerzanka, A.; MacKie, A. The Role of Bile Salts in Digestion. In Advances in Colloid and Interface Science; Elsevier, 2011; Vol. 165, pp 36-46. https://doi.org/10.1016/j.cis.2010.12.002.

(39) Paz-Yépez, C.; Peinado, I.; Heredia, A.; Andrés, A. Influence of Particle Size and Intestinal Conditions on in Vitro Lipid and Protein Digestibility of Walnuts and Peanuts. Food Research International 2019, 119 , 951-959. https://doi.org/10.1016/j.foodres.2018.11.014.

(40) Levi, S.; Lesmes, U. Bi-Compartmental Elderly or Adult Dynamic Digestion Models Applied to Interrogate Protein Digestibility †. 2014. https://doi.org/10.1039/c4fo00478g.

(41) Rémond, D.; Shahar, D. R.; Gille, D.; Pinto, P.; Kachal, J.; Peyron, M. 
A.; Dos Santos, C. N.; Walther, B.; Bordoni, A.; Dupont, D.; TomásCobos, L.; Vergères, G. Understanding the Gastrointestinal Tract of the Elderly to Develop Dietary Solutions That Prevent Malnutrition. Oncotarget 2015, 6 (16), 13858-13898. https://doi.org/10.18632/oncotarget.4030.

(42) Ceballos, L. S.; Morales, E. R.; de la Torre Adarve, G.; Castro, J. D.; Martínez, L. P.; Sampelayo, M. R. S. Composition of Goat and Cow Milk Produced under Similar Conditions and Analyzed by Identical Methodology. Journal of Food Composition and Analysis 2009, 22 (4), 322-329. https://doi.org/10.1016/j.jfca.2008.10.020.

(43) Germani, A.; Luneia, R.; Nigro, F.; Vitiello, V.; Donini, L. M.; Del Balzo, V. The Yogurt Amino Acid Profile's Variation during the Shelf-Life. Ann. Ig 2014, 26, 205-212.

(44) Salvia-Trujillo, L.; Verkempinck, S. H. E.; Sun, L.; Van Loey, A. M.; Grauwet, T.; Hendrickx, M. E. Lipid Digestion, Micelle Formation and Carotenoid Bioaccessibility Kinetics: Influence of Emulsion Droplet Size. Food Chemistry 2017, 229, 653-662. https://doi.org/10.1016/j.foodchem.2017.02.146.

(45) Harper, E. J. Changing Perspectives on Aging and Energy Requirements: Aging and Digestive Function in Humans, Dogs and Cats. The Journal of Nutrition 1998, 128 (12), 2632S-2635S. https://doi.org/10.1093/jn/128.12.2632s.

(46) Lamothe, S.; Corbeil, M. M.; Turgeon, S. L.; Britten, M. Influence of Cheese Matrix on Lipid Digestion in a Simulated Gastro-Intestinal Environment. In Food and Function; The Royal Society of Chemistry, 2012; Vol. 3, pp 724-731. https://doi.org/10.1039/c2fo10256k.

(47) Wang, X.; Ye, A.; Lin, Q.; Han, J.; Singh, H. Gastric Digestion of Milk Protein Ingredients: Study Using an in Vitro Dynamic Model. Journal of Dairy Science 2018, 101 (8), 6842-6852. https://doi.org/10.3168/jds.2017-14284. 
(48) Lorieau, L.; Le Roux, L.; Gaucheron, F.; Ligneul, A.; Hazart, E.; Dupont, D.; Floury, J. Bioaccessibility of Four Calcium Sources in Different Whey-Based Dairy Matrices Assessed by in Vitro Digestion. Food Chemistry 2018, 245, 454-462. https://doi.org/10.1016/j.foodchem.2017.10.108.

(49) Etcheverry, P.; Grusak, M. A.; Fleige, L. E. Application of in Vitro Bioaccessibility and Bioavailability Methods for Calcium, Carotenoids, Folate, Iron, Magnesium, Polyphenols, Zinc, and Vitamins B 6, B 12, D, and E. Frontiers in Physiology. 2012. https://doi.org/10.3389/fphys.2012.00317.

(50) Kawahara, T.; Aruga, K.; Otani, H. Characterization of Casein Phosphopeptides from Fermented Milk Products; 2005; Vol. 51.

(51) Borel, P. Factors Affecting Intestinal Absorption of Highly Lipophilic Food Microconstituents (Fat-Soluble Vitamins, Carotenoids and Phytosterols). Clinical Chemistry and Laboratory Medicine. January 7, 2003, pp 979-994. https://doi.org/10.1515/CCLM.2003.151.

(52) Werner, A.; Kuipers, F.; Verkade, H. J. Fat Absorption and Lipid Metabolism in Cholestasis. In Madame Curie Bioscience Database [Internet]; Landes Bioscience, 2013. 
5.3 Chapter 3: Impact of cooking preparation on in vitro digestion of eggs simulating some gastrointestinal alterations in elders.

Ever Hernández-Olivas, Sara Muñoz-Pina, Ana Andrés and Ana Heredia Journal of Agricultural and Food Chemistry 2021. https://doi.org/10.1021/acs.jafc.0c07418. 

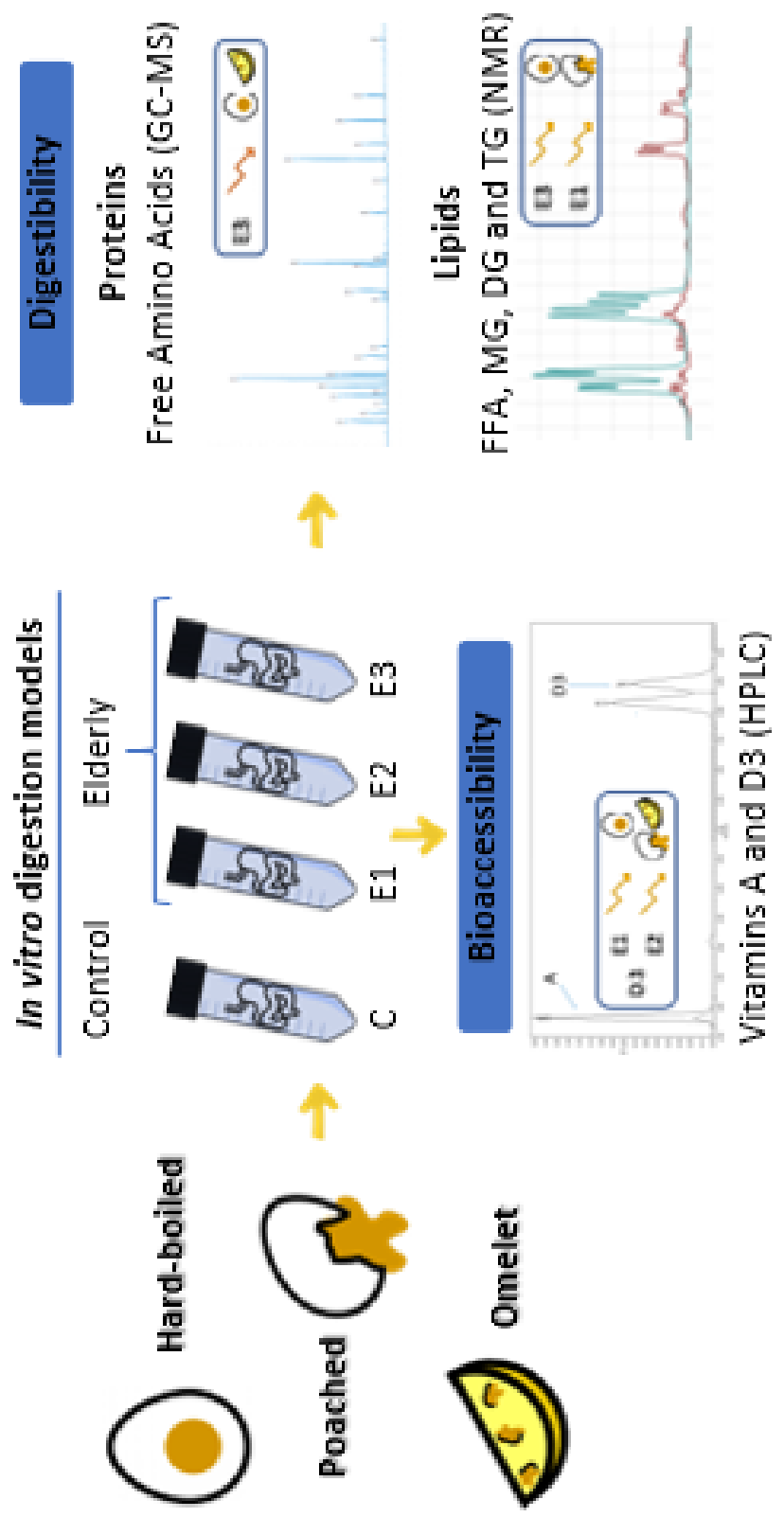


\section{Abstract}

This study aimed to in vitro assess the impact of cooking process of eggs (hard-boiled, poached and omelet) on nutrients digestibility and vitamins A and D3 bioaccessibility under elderly gastrointestinal (GI) conditions. Three elderly digestion models were mimicked: oral (E1), oral and gastric (E2) and oral, gastric and intestinal (E3), and a healthy adult model (C). Proteolysis extent reduced after digestion of omelet under E3 model ( $p<0.05)$ (up to $37 \%$ of reduction). Thus, hard-boiled and poached were more recommendable to enhance protein digestibility in elders. Altered GI conditions negatively influence neither the absorbable lipid fraction nor the cholesterol stability. Finally, vitamin A bioaccessibility was not affected but D3 slightly decreased with the elderly (E3). Hence, the digestion of nutrients was dependent on the resulting matrix, poached being the greater supplier of protein and lipid end-digestion products. Poached and omelet, however, offer high net supply of bioaccessible vitamin D3 for elders.

Keywords: aging; egg; cooking methods; macronutrients digestibility; vitamins bioaccessibility. 


\section{INTRODUCTION}

Current prospects confirm that the population continues to considerably grow because of both high fertility and life expectancy. At the same time, it is expected that people aged 65 years, or over, surpasses infants and youth in number by $2050^{1}$. Consequently, elders wellness is a global concern that involves lifestyle and nutritional issues ${ }^{2}$. The European Society for Clinical Nutrition and Metabolism recommends the elders to increase the consumption of rich-protein foods with high amounts of micronutrients ${ }^{3}$, and especially those rich in essential amino acids such as leucine or tryptophan ${ }^{4}$. Besides, healthy lipids, minerals and vitamins contents are also important due to their relevance as immune-modulators and their contribution to the bone health of these subjects ${ }^{5}$. Physiological functions declining with ageing include body composition, brain function, gastrointestinal (GI) tract function, fluid balance, bones and joints or cardiovascular system, among others ${ }^{6}$. Sarcopenia, loss of muscle mass associated with a protein deficit, asthenia, depression or weakness of the immune system often occur in the elderly ${ }^{7,8}$. The masticatory deficiency in elderly, i.e., leading into food boluses with larger particle size distribution and more difficult to swallow, has been reported to influence the nutrients digestibility ${ }^{9}$. Also, a decline in the $\mathrm{Gl}$ tract function has been reported to be partially responsible for the protein deficit. The secretion of digestive fluids and enzymes, saliva, peristaltic contractions and chyme passage rates could be suboptimal resulting in mal-digestion and mal-absorption of nutrients, and among them of proteins and vitamins ${ }^{10-12}$.

Among the dietary protein and micronutrients sources, egg is considered as a moderate calorie source (about $140 \mathrm{kcal} / 100 \mathrm{~g}$ ) and the lowest-cost animal source of proteins, vitamin A, iron, vitamin B12, riboflavin, choline, and the second lowest-cost source for zinc and calcium. Egg proteins are 
distributed equally between egg white and egg yolk, while lipids, vitamins, and minerals are essentially concentrated in egg yolk ${ }^{13}$. Raw egg yolk contains high amount of vitamin A and D3 (371 and $5.4 \mu \mathrm{g} / 100 \mathrm{~g}$, respectively), among others ${ }^{13}$. Proteins provide a reasonable supply of amino acids of biological value ${ }^{14}$, with a digestible indispensable amino acid score (DIAAS) value of 1.13 in the same high level of the whole milk with 1.14 score ${ }^{15}$. The relative amount of mono and poly unsaturated to saturated fatty acids in yolk is particularly higher than other animal-derived foods. Besides, even though egg cholesterol content is high, it has been reported to not negatively contribute to the increase in plasma totalcholesterol ${ }^{13}$. Therefore, a regular egg consumption of about 6 per week is advisable ${ }^{16}$. Thus, egg is one of the most eaten food over the world and is served in such a variety of ways and recipes ${ }^{17}$.

Egg meal preparation often involves a heating treatment resulting in protein denaturation, greater vitamins and minerals availability ${ }^{18}$, but also loss, anti-nutritional factors decrease, among others. The extent of these changes will depend on the way of cooking and the intensity of the heating ${ }^{14}$. Additionally, cooking implies a serial of structural changes, which could modulate digestion and absorption rates (i.e. amino acid isomerization and desulfurization, reactions with sugars and lipids, etc.); therefore, having an impact on health benefits coming from egg consumption ${ }^{19}$. Among the most common ways of cooking eggs, it can be cited hard and soft boiled, hard and soft scrambled, omelet or sunny side up, among others. Literature reports the impact of the egg protein structure on proteolysis in model systems consisting in white gels. Studies performed at static ${ }^{19-21}$ but also at dynamic in vitro systems ${ }^{21,22}$ clearly evidencing the role of the matrix structure. However, information related to the modulation of egg protein digestibility neither by cooking nor under elderly $\mathrm{Gl}$ conditions has been previously reported in real foods. 
In this context, this study aims at in vitro analyzing the impact of elderly gastrointestinal conditions and egg cooking (hard-boiled, poached and omelet) on proteolysis, lipolysis, and vitamins A and D3 bioaccessibility.

\section{MATERIAL AND METHODS}

\section{Chemicals}

Pepsin from the porcine gastric mucosa (3200-4500 U/mg), pancreatin (8 x USP) from porcine pancreas, bile bovine (dried, unfractionated), analytical grade salts (potassium chloride, potassium dihydrogen phosphate, sodium bicarbonate, sodium chloride, magnesium chloride, ammonium carbonate, calcium chloride and potassium sulfate), boric acid, hydrochloric acid (37\%), sulfuric acid (95-97\%), tetrahydrofuran (HPLC grade), methanol (HPLC grade), retinol ( $\geq 99 \%$, HPLC grade), cholecalciferol ( $\geq 98 \%$, HPLC grade), sodium hydroxide, were obtained from Sigma-Aldrich (Deisenhofen, Germany). Also, petroleum ether (VWR Chemicals), acetonitrile HPLC grade (JT Baker), and EZ-Faast amino acid kit (Phenomenex) were used.

Standard eggs were purchased at local stores in Valencia (Spain).

\section{Sample preparation}

Fresh hen eggs were cooked according to Asensio-Grau et al. (2018) ${ }^{23}$ and immediately characterized or in vitro digested. For the hard-boiled whole shell, eggs were boiled with water covering the eggs for $10 \min \left(95 \pm 5^{\circ} \mathrm{C}\right)$ and cooled under running tap water for $5 \mathrm{~min}$, and they were peeled right after. For poached preparation, eggs were broken and wrapped into clingfilm before boiling them with boiling water for $4 \min \left(95 \pm 5^{\circ} \mathrm{C}\right)$ and cooled under running tap water for $5 \mathrm{~min}$. For omelet, a white:yolk ratio of 70:30 (w:w) was mixed and stirred for $1 \mathrm{~min}$ before microwave-cooking at 12.5 $\mathrm{W} / \mathrm{g}$ for $80 \mathrm{~s}$ without oil addition. The egg white and yolks resulted from 
hard-boiling and poaching were separated to be added to the digestion tubes in the same white:yolk ratio as in omelet.

\section{Compositional analysis}

After cooking, moisture, ashes, fat and protein contents were determined according to the official methods 934.01, 942.05, 920.39 and $960.52{ }^{24}$, respectively. Carbohydrates were calculated by difference (100 g minus the sum of grams of water, ashes, lipids and protein, in wet basis) ${ }^{25}$. Besides, 5 $\mathrm{g}$ of samples were subjected to saponification and extraction of vitamins $A$ (retinol) and D3 (cholecalciferol) according to the protocol published by Castaneda and Lee (2019) ${ }^{26}$. Both liposoluble vitamins were separated by chromatography (RP-HPLC) and detected at 265 and $325 \mathrm{~nm}$ for vitamin D3 and vitamin A, respectively ${ }^{27}$. Additionally, cold lipid extraction was performed to analyze the egg lipid profile by means of Proton Nuclear Magnetic Resonance (1H-NMR) (Bruker, model 400/R), according to NievaEchevarría et al. (2018) ${ }^{28}$. The molar percentage of triglycerides (TG), diglycerides (1,2-DG and 1,3-DG), monoglycerides (1-MG and 2-MG) and free fatty acids (FFA) were determined in the samples. In order to assess its stability after the egg cooking and digestion, the cholesterol content was also quantified by $1 \mathrm{H}-\mathrm{RNM}$, as a minor lipidic component.

Determinations were performed by triplicate in at least 3 independent eggs for each cooking method.

\section{Static in vitro simulation of GI digestion}

Four in vitro models were stated according to Hernández-Olivas et al. (2020) 27 to determine the contribution of the different alterations and deterioration occurring with aging (i.e., mastication deficiency, secretion of digestive fluids and enzymes, saliva, GI tract contractions and chyme passage rates) ${ }^{9,12}$ on the macronutrients digestibility and micronutrients 
bioaccessibility in the cooked eggs. Figure 5.3.1 gathers the specific conditions of each simulation model (Elderly 1 (E1), Elderly 2 (E2), Elderly 3 (E3), and control (C)). Gl altered conditions of elderly models E1, E2 and E3 were based on Shani-Levi et al. (2017) ${ }^{12}$, while C model corresponded to Minekus et al. (2014) ${ }^{29}$. Three independent digestion assays were carried out for each C, E1, E2 and E3 Gl conditions. $5 \mathrm{~g}$ of cooked eggs (hard-boiled, poached and omelet) ensuring a 70:30 white:yolk ratio were digested by triplicate under each GI model (C, E1, E2 and E3). Gastric and intestinal stages were in vitro simulated while oral stage was in vivo performed by a volunteer with healthy dentition. The number of mastication cycles to reach a bolus with similar physical characteristics to that of a tomato or mustard paste was established at $16{ }^{30}$. Once this parameter was established, chewing cycles were reduced to $50 \%$ to mimic suboptimal oral conditions given in elders ${ }^{27}$. Before digestion experiments, gastric (SGF) and intestinal (SIF) digestion fluids were prepared fresh daily from stock solutions and the enzymatic activity of digestive enzymes was tested following the protocol proposed by Minekus et al. (2014) ${ }^{29}$.

After in vitro digestion, sample $\mathrm{pH}$ was adjusted to 5 and kept in an ice bath for $10 \mathrm{~min}$ to inhibit the enzymatic reactions before fraction separation. Separation of the bioaccessible fraction (liquid phase) from the remaining solid phase was performed by centrifuging at $4,000 \times \mathrm{g}$ during $5 \mathrm{~min}$ at $10^{\circ} \mathrm{C}$ and the supernatant collected as bioaccessible fraction. Aliquots of the bioaccessible fraction were immediately frozen and stored until their use for the analytical determinations. 


\section{IN VITRO DIGESTION MODELS}

\begin{tabular}{|c|c|c|c|c|}
\hline Stage & Control & $\begin{array}{c}\text { Elderly } 1 \\
\text { (E1) }\end{array}$ & $\begin{array}{c}\text { Elderly } 2 \\
\text { (E2) }\end{array}$ & $\begin{array}{c}\text { Elderly } 3 \\
\text { (E3) }\end{array}$ \\
\hline Oral & $\checkmark$ & $x$ & $x$ & $x$ \\
\hline Gastric & $\checkmark$ & $\checkmark$ & $x$ & $x$ \\
\hline Intestinal & $\checkmark$ & $\checkmark$ & $\checkmark$ & $x$ \\
\hline $\begin{array}{c}\text { Control } \\
\text { conditions }\end{array}$ & \multicolumn{4}{|c|}{$\begin{array}{l}\text { Oral stage: } 5 \mathrm{~g} \text { of food sample }+ \text { human salivary fluid, chewing until a } \\
\text { consistency like a tomato or mustard paste ( } 16 \text { for all samples). } \\
\text { Gastric stage: Oral bolus }+10 \mathrm{~mL} \text { SGF, pH } 3 \text {, pepsin }(2000 \mathrm{U} / \mathrm{mL}), 2 \mathrm{~h} \text {, } \\
55 \mathrm{rpm} \text { at } 37^{\circ} \mathrm{C} \text {. } \\
\text { Intestinal stage: Gastric chime }+20 \mathrm{~mL} \mathrm{SIF,} \mathrm{pH} 7 \text {, bile }(10 \mathrm{mM})+ \\
\text { pancreatin }(100 \mathrm{U} / \mathrm{mL}), 2 \mathrm{~h}, 55 \mathrm{rpm} \text { at } 37^{\circ} \mathrm{C} \text {. }\end{array}$} \\
\hline
\end{tabular}

Figure 5.3.1. Specific gastrointestinal conditions set for the four in vitro digestion models of this study.

\section{Analytical determinations in digesta}

\section{Free amino acids}

Free amino acids (essential and non-essential amino acids (EAA and NEAA)) resulting from protein digestion were determined through the protocol published by Peinado et al. (2016) ${ }^{31}$ with some amendments. The resulted amino acids were classified into groups according to their chemical structure (Hydrophobic amino acids (HAA = Ala, Val, Ile, Leu, Tyr, Phe, Trp, Pro, Met, Cys); Positively charged amino acids (PCAA = Lys, His); Negatively charged amino acids (NCAA = Asp, Asn, Glu, Gln); Aromatic amino acids $\left(\mathrm{AAA}=\right.$ Phe, Trp, Tyr); Sulfur containing amino acids $(\mathrm{SCAA}=\mathrm{Cys}$, Met $){ }^{32}$. Briefly, $100 \mu \mathrm{L}$ of bioaccessible fraction were derivatized using the EZ-Faast amino acid kit, analyzed using a GC-MS (Agilent Technologies, Injector 7683B series, Network GC System 6890N series, Inert Mass Selective Detector 5975 series, MSD ChemStation software). Norvaline was used as 
internal standard. The extent of proteolysis based in free amino acids was calculated according to equation 1 :

Proteolysis extent (\%)

$$
=\frac{(\text { gFAA'S released in bioaccessible fraction })}{(g \text { initial protein in undigested food })} \times 100
$$

Where: the FAA released corresponds to the sum of the free amino acids in the bioaccessible fraction.

\section{Lipidic end-digestion products}

Digesta samples were subjected to cold liquid-liquid extraction and the composition of the lipid phase, including cholesterol, determined by $1 \mathrm{H}$ NMR following the same procedure explained in the compositional analysis section. Thus, absorbable and non-absorbable lipid fractions, as well as the lipolysis extent, were calculated according to equations 5.9, 5.10 and 5.11:

Absorbable lipid fraction $=A G_{2-\mathrm{MG}} \%+A G_{1-M G} \%+\mathrm{FFA} \%$

Non-absorbable lipid fraction $=A G_{1,2-D G} \%+A G_{1,3-D G} \%$

Lipolysis extent (\%)

$$
\begin{aligned}
& =\text { Absorbable lipid fraction } \\
& + \text { Non-absorbable lipid fraction }
\end{aligned}
$$


Where: 1,2-DG and 1,3-DG correspond to diglycerides; 1-MG and 2-MG to monoglycerides; and FFA to free fatty acids obtained in the digested samples.

\section{Vitamin A and D3 bioaccessibility}

$20 \mathrm{~mL}$ of the bioaccessible fraction were subjected to saponification and extraction to determine the bioaccessibility of vitamin A and D3 following the same protocol as for total vitamin content in undigested cooked eggs (compositional analysis section). Vitamin bioaccessibility was calculated according to equation 5.12 :

Vitamin bioaccessibility $(\%)=\frac{(\mu g \text { of released vitamin })}{(\mu g \text { of total vitamin })} \times 100$

Where: the amount of released vitamin represents the recovered part in the bioaccessible fraction after in vitro digestion and the total amount of vitamin found in the cooked eggs before in vitro digestion.

\section{Statistical analysis}

An analysis of variance (Multivariate ANOVA) was performed and multiple range test was determined by the LSD (Less Significant Difference) of Fisher test to identify homogeneous groups between models and cooked eggs using Statgraphics Centurion XVII software with a confidence level of 95\% ( $p$ <0.05). Also, a Principal Component Analysis (PCA) was applied to find out the relationship among the experimental data (EAA/NEAA ratio, total, HAA, PCAA, NCAA, AAA and SCAA proteolysis extents, absorbable and nonabsorbable lipid fractions, lipolysis extent, cholesterol content and vitamin A and D3 bioaccessibility) obtained from in vitro digestion studies carried 
out in cooked eggs under elderly (E1, E2 and E3) or standard (C) GI conditions.

\section{RESULTS AND DISCUSSION}

\section{Effect of cooking on egg composition}

The nutritional composition of eggs was evaluated immediately after being cooked and the values are gathered in Table 5.3.1. Even though the egg nutritional contents are highly dependent on the hen feed composition ${ }^{33}$, macronutrients content (protein and fat) were closed to those reported for non-cooked egg ${ }^{34-37}$. Therefore, no losses of protein or fat were observed during cooking. Regarding the water content, the shell (in hard-boiled egg) and the plastic film used during poached avoided the sample dehydration compared with the omelet in the open-air preparation. Concerning the analyzed vitamins, cooked eggs presented lower values of vitamin A but similar to D3 compared to the contents reported in fresh egg ${ }^{34,35,37}$. A decrease of yolk hydrophobic micronutrients has been previously reported after cooking ${ }^{38}$, vitamin A being more sensitive to light, oxygen and temperature than other liposoluble vitamins ${ }^{39}$. In addition, Hemery et al. (2015) ${ }^{40}$ report a greater effect of photolysis than oxidation on vitamin A. Reasonably, the lower vitamin A content found in omelet, compared to hard-boiled and poached egg, can be due to a greater yolk exposure to light and oxygen than during the other cooking ways. In omelet preparation, the shell is removed, yolk and egg white mixed, stirred and placed in a plate resulting in a larger interphase surface to thermal heating than in boiled or poached. With respect to vitamin D3, omelet presented higher content than hard-boiled or 
poached eggs. Hemery et al. (2015) ${ }^{40}$ report that the impact of light or oxygen exposure on vitamin D3 is not as severe as for vitamin A. Vitamin D3 seems to be sensible to heat and decrease as long as the processing time increases ${ }^{41,42}$. Thus, the lower cooking time involved in the microwave preparation of omelet ( $80 \mathrm{~s}$ compared to 4 and 10 min, respectively) could be associated to the better preservation of vitamin D3 compared to boiling and poaching. 
Table 5.3.1. Total Contents (per $100 \mathrm{~g}$ Dry Basis) of Water, Protein, Fat, Ashes, Carbohydrates, Vitamin A and Vitamin D3 of Hard-boiled, Poached and Omelet Eggs ${ }^{e}$

\begin{tabular}{lllll}
\hline \hline Nutrient content & Raw $^{d}$ & Hard-boiled & Poached & Omelet \\
\hline \hline Water (g) & $292-308$ & $310 \pm 3^{b}$ & $319 \pm 3^{c}$ & $154 \pm 2^{a}$ \\
Protein (g) & $47-52$ & $51.6 \pm 0.2^{b}$ & $49.5 \pm 0.6^{a}$ & $51.8 \pm 0.3^{b}$ \\
Fat (g) & $35-48$ & $35.4 \pm 0.6^{a}$ & $35.0 \pm 1.0^{a}$ & $33.4 \pm 1.7^{a}$ \\
Ashes (g) & $3.4-3.6$ & $5.9 \pm 0.1^{a}$ & $5.9 \pm 0.1^{a}$ & $5.8 \pm 0.1^{a}$ \\
Carbohydrates (g) & $0.7-3.8$ & $4.9 \pm 0.1^{b}$ & $4.6 \pm 0.1^{a}$ & $5.1 \pm 0.1^{c}$ \\
Vitamin A ( $\mu \mathrm{g})$ & $560-1112$ & $690 \pm 30^{b}$ & $700 \pm 30^{b}$ & $376 \pm 18^{a}$ \\
Vitamin D3 ( $\mu \mathrm{g})$ & $5-12$ & $6.3 \pm 0.3^{a}$ & $6.5 \pm 0.3^{a}$ & $11.2 \pm 0.4^{b}$ \\
\hline \hline
\end{tabular}

a, b, c Different lowercase letters indicate significant differences between foods, with a significance level of $95 \%(p<0.05){ }^{d}$ Intervals based on literature ${ }^{34-37}$. e Data shown are mean values and standard deviation from three independent eggs. 


\section{Effect of egg cooking on gastrointestinal proteolysis in elders}

Figure 5.3.2A shows the proteolysis extent (\%) obtained from the free amino acids profile (Tables 5.3.2, 5.3.3 and 5.3.4) achieved after in vitro gastrointestinal digestion of boiled, poached and omelet eggs simulating different models (standardized (C) and elderly (E1, E2 and E3)). It can be noted that proteolysis extent was much higher in boiled eggs (79 \%) than in poached and omelet ones (60 and $56 \%$, respectively) under control Gl conditions. Apparently, trypsin inhibitors present in white eggs seem to be inactivated as long as the food is exposed to $100{ }^{\circ} \mathrm{C}$ as well as a greater protein denaturation 13,14 , leading to a greater extent in hard-boiled than in poached and omelet. It is well known that the different ways of egg cooking lead to different matrix structures, physical behavior, sensorial quality and composition of eggs ${ }^{43}$. Therefore, an impact of cooking eggs on digestibility was expected. In the case of omelet, the mixing and stirring of yolk with white egg seem to generate new protein-lipid organization that, together with the solid structure resulting from the heat treatment, would hinder the access of gastric and pancreatic proteases to the substrate and result in lower protein digestion ${ }^{23}$. It is important to highlight that the extent of proteolysis achieved by the samples, could be even higher than reported because of the extent of proteolysis calculation has been just based on FAA without considering the possible short-chain peptides which are also bioabsorbable.

Concerning the effect of Gl alterations of elders in egg digestion, results also show that neither oral nor gastric alterations (E1 and E2) negatively impacted in vitro proteolysis extent (sum of the FAA 163 
Table 5.3.2. Amino Acids Profile (g/100 g Initial Protein) Resulting from In Vitro Digestion of Hard-boiled Egg under Different Simulated GI Conditions (Control (C), Elderly 1 (E1), Elderly 2 (E2), Elderly 3 (E3) Models) ${ }^{d}$

\begin{tabular}{|c|c|c|c|c|}
\hline \multirow{2}{*}{ Amino acid } & \multicolumn{4}{|c|}{ Hard-boiled } \\
\hline & C & E1 & E2 & E3 \\
\hline Alanine (Ala) & $4.39 \pm 0.15^{C B}$ & $3.68 \pm 0.28^{b c}$ & $3.67 \pm 0.37^{b B}$ & $2.50 \pm 0.12^{a B}$ \\
\hline Glycine (Gly) & $1.48 \pm 0.25^{b B}$ & $1.50 \pm 0.24^{b B}$ & $1.53 \pm 0.16^{b c}$ & $0.48 \pm 0.12^{a A B}$ \\
\hline Valine (Val) & $5.77 \pm 0.01^{b B}$ & $5.77 \pm 0.64^{b B}$ & $6.07 \pm 0.58^{b c}$ & $4.18 \pm 0.34^{a B}$ \\
\hline Leucine (Leu) & $10.37 \pm 0.26^{b B}$ & $10.08 \pm 1.28^{b B}$ & $10.86 \pm 1.08^{b B}$ & $7.49 \pm 0.58^{a A B}$ \\
\hline Isoleucine (Ile) & $4.29 \pm 0.07^{b B}$ & $4.24 \pm 0.28^{a b B}$ & $4.01 \pm 0.92^{a b A}$ & $3.12 \pm 0.22^{a A B}$ \\
\hline Threonine (Thr) & $3.25 \pm 0.26^{b B}$ & $2.96 \pm 0.20^{b c}$ & $3.12 \pm 0.34^{b c}$ & $1.77 \pm 0.15^{a B}$ \\
\hline Serine (Ser) & $3.71 \pm 0.18^{b B}$ & $3.43 \pm 0.33^{b B}$ & $3.65 \pm 0.38^{b c}$ & $1.40 \pm 0.10^{a B}$ \\
\hline Proline (Pro) & $1.24 \pm 0.05^{b c}$ & $1.15 \pm 0.15^{b B}$ & $1.27 \pm 0.16^{b c}$ & $0.67 \pm 0.06^{a B}$ \\
\hline Asparagine (Asn) & $2.73 \pm 0.56^{a B}$ & $2.48 \pm 0.23^{a B}$ & $2.65 \pm 0.28^{a B}$ & - \\
\hline Aspartic acid (Asp) & $2.40 \pm 0.10^{b B}$ & $2.31 \pm 0.32^{b B}$ & $2.32 \pm 0.28^{b B}$ & $0.19 \pm 0.06^{a A}$ \\
\hline Methionine (Met) & $3.24 \pm 0.12^{a b B}$ & $3.06 \pm 0.53^{a b A B}$ & $3.39 \pm 0.39^{b B}$ & $2.57 \pm 0.11^{a A}$ \\
\hline Glutamic acid (Glu) & $3.20 \pm 0.42^{b B}$ & $3.10 \pm 0.18^{a b B}$ & $3.12 \pm 0.15^{a b B}$ & $2.54 \pm 0.18^{a B}$ \\
\hline Phenylalanine (Phe) & $6.56 \pm 0.15^{b B}$ & $6.66 \pm 1.10^{b B}$ & $7.35 \pm 0.77^{b B}$ & $4.91 \pm 0.27^{a A}$ \\
\hline Glutamine (GIn) & $6.60 \pm 0.11^{b c}$ & $5.85 \pm 0.93^{b c}$ & $6.49 \pm 0.77^{b c}$ & $4.20 \pm 0.24^{a B}$ \\
\hline Lysine (Lys) & $7.87 \pm 1.18^{b B}$ & $7.36 \pm 0.26^{b B}$ & $8.52 \pm 0.31^{b c}$ & $4.33 \pm 0.71^{a B}$ \\
\hline Histidine (His) & $2.32 \pm 0.14^{b B}$ & $2.60 \pm 0.43^{b B}$ & $2.85 \pm 0.31^{b c}$ & $1.60 \pm 0.09^{a B}$ \\
\hline Tyrosine (Tyr) & $6.96 \pm 0.25^{b c}$ & $7.14 \pm 0.72^{b B}$ & $7.62 \pm 0.95^{b c}$ & $4.88 \pm 0.16^{a C}$ \\
\hline Tryptophan (Trp) & $2.75 \pm 0.06^{a b A}$ & $3.01 \pm 0.34^{b c B}$ & $3.53 \pm 0.36^{c B}$ & $2.18 \pm 0.12^{a B}$ \\
\hline Cystine (Cys) & - & - & - & - \\
\hline
\end{tabular}


Table 5.3.3. Amino Acids Profile (g /100 g Initial Protein) Resulting from In Vitro Digestion of Poached Egg under Different Simulated GI Conditions (Control (C), Elderly 1 (E1), Elderly 2 (E2), Elderly 3 (E3) Models) ${ }^{d}$

\begin{tabular}{|c|c|c|c|c|}
\hline \multirow{2}{*}{ Amino acid } & \multicolumn{4}{|c|}{ Poached } \\
\hline & C & E1 & E2 & E3 \\
\hline Alanine (Ala) & $3.05 \pm 0.42^{a A}$ & $3.21 \pm 0.09^{a B}$ & $3.00 \pm 0.34^{a B}$ & $2.63 \pm 0.18^{a B}$ \\
\hline Glycine (Gly) & $1.24 \pm 0.26^{b B}$ & $1.16 \pm 0.10^{b B}$ & $1.14 \pm 0.04^{b B}$ & $0.51 \pm 0.02^{a B}$ \\
\hline Valine (Val) & $4.78 \pm 0.38^{a A}$ & $5.20 \pm 0.09^{a B}$ & $4.52 \pm 0.25^{a B}$ & $4.72 \pm 0.38^{a B}$ \\
\hline Leucine (Leu) & $8.72 \pm 0.47^{a A}$ & $8.65 \pm 0.26^{a B}$ & $7.88 \pm 0.12^{a A}$ & $8.13 \pm 0.46^{a B}$ \\
\hline Isoleucine (Ile) & $3.63 \pm 0.32^{a A}$ & $3.87 \pm 0.12^{a B}$ & $3.10 \pm 0.51^{a A}$ & $3.45 \pm 0.40^{a B}$ \\
\hline Threonine (Thr) & $2.22 \pm 0.28^{a b A}$ & $2.61 \pm 0.06^{c B}$ & $2.19 \pm 0.13^{b c B}$ & $1.88 \pm 0.20^{a B}$ \\
\hline Serine (Ser) & $2.29 \pm 0.21^{a b A}$ & $2.96 \pm 0.30^{b B}$ & $2.62 \pm 0.19^{a b B}$ & $1.87 \pm 0.28^{a c}$ \\
\hline Proline (Pro) & $1.01 \pm 0.10^{a b B}$ & $1.15 \pm 0.01^{b B}$ & $0.98 \pm 0.11^{a b B}$ & $0.76 \pm 0.12^{a c}$ \\
\hline Asparagine (Asn) & $2.00 \pm 0.40^{a A B}$ & $2.74 \pm 0.24^{a B}$ & $2.11 \pm 0.38^{a A B}$ & - \\
\hline Aspartic acid (Asp) & $1.83 \pm 0.13^{b A}$ & $2.27 \pm 0.08^{b B}$ & $2.10 \pm 0.16^{b B}$ & $1.17 \pm 0.26^{a c}$ \\
\hline Methionine (Met) & $2.80 \pm 0.24^{a A}$ & $3.00 \pm 0.03^{a B}$ & $2.60 \pm 0.10^{a A}$ & $2.58 \pm 0.46^{a A}$ \\
\hline Glutamic acid (Glu) & $3.02 \pm 0.10^{b B}$ & $3.32 \pm 0.10^{C B}$ & $2.97 \pm 0.10^{b B}$ & $2.66 \pm 0.07^{a B}$ \\
\hline Phenylalanine (Phe) & $5.90 \pm 0.21^{c A}$ & $5.63 \pm 0.30^{b c A B}$ & $4.84 \pm 0.09^{a A}$ & $5.01 \pm 0.44^{a b A}$ \\
\hline Glutamine (GIn) & $4.58 \pm 0.41^{a B}$ & $4.48 \pm 0.43^{a B}$ & $4.97 \pm 0.84^{a B}$ & $4.22 \pm 0.36^{a B}$ \\
\hline Lysine (Lys) & $4.43 \pm 0.43^{a A}$ & $6.37 \pm 0.75^{b B}$ & $5.97 \pm 0.21^{b B}$ & $5.17 \pm 0.05^{a c}$ \\
\hline Histidine (His) & $2.19 \pm 0.08^{b B}$ & $1.99 \pm 0.20^{a b B}$ & $2.03 \pm 0.08^{a b B}$ & $1.92 \pm 0.11^{a c}$ \\
\hline Tyrosine (Tyr) & $3.48 \pm 0.09^{a b A}$ & $3.56 \pm 0.06^{a b A}$ & $3.12 \pm 0.01^{a A}$ & $3.81 \pm 0.41^{b B}$ \\
\hline Tryptophan (Trp) & $2.65 \pm 0.18^{b A}$ & $2.37 \pm 0.27^{a b A}$ & $2.18 \pm 0.18^{a A}$ & $2.29 \pm 0.06^{a b B}$ \\
\hline Cystine (Cys) & - & - & - & - \\
\hline
\end{tabular}

$\overline{a, b, c}$ Different lowercase letters indicate significant differences between models, with a significance level of $95 \%(p<0.05)$. A,B,C Different capital letters indicate significant differences between cooking methods (Tables 5.3.2, 5.3.3 and 5.3.4), with a significance level of $95 \%$ $(p<0.05) .{ }^{d}$ Data shown are mean values from triplicates and the standard deviation. 
Table 5.3.4. Amino Acids Profile (g /100 g Initial Protein) Resulting from In Vitro Digestion of Omelet Egg under Different Simulated GI Conditions (Control (C), Elderly 1 (E1), Elderly 2 (E2), Elderly 3 (E3) Models) ${ }^{d}$

\begin{tabular}{|c|c|c|c|c|}
\hline \multirow{2}{*}{ Amino acid } & \multicolumn{4}{|c|}{ Omelet } \\
\hline & C & E1 & E2 & E3 \\
\hline Alanine (Ala) & $2.65 \pm 0.34^{b A}$ & $2.23 \pm 0.09^{b A}$ & $2.42 \pm 0.13^{b A}$ & $1.76 \pm 0.12^{a A}$ \\
\hline Glycine (Gly) & $0.83 \pm 0.12^{b A}$ & $0.66 \pm 0.02^{b A}$ & $0.70 \pm 0.08^{b A}$ & $0.33 \pm 0.07^{a A}$ \\
\hline Valine (Val) & $4.49 \pm 0.52^{b A}$ & $3.77 \pm 0.10^{a b A}$ & $3.94 \pm 0.19^{a b A}$ & $3.15 \pm 0.49^{a A}$ \\
\hline Leucine (Leu) & $8.91 \pm 0.88^{b A}$ & $7.46 \pm 0.37^{a A}$ & $7.60 \pm 0.40^{a A}$ & $6.81 \pm 0.30^{a A}$ \\
\hline Isoleucine (Ile) & $3.51 \pm 0.32^{b A}$ & $2.92 \pm 0.17^{a A}$ & $3.01 \pm 0.19^{a b A}$ & $2.78 \pm 0.18^{a A}$ \\
\hline Threonine (Thr) & $2.02 \pm 0.33^{b A}$ & $1.79 \pm 0.04^{b A}$ & $1.91 \pm 0.05^{b A}$ & $1.39 \pm 0.08^{a A}$ \\
\hline Serine (Ser) & $2.21 \pm 0.39^{b A}$ & $1.97 \pm 0.14^{b A}$ & $2.15 \pm 0.12^{b A}$ & $1.13 \pm 0.07^{a A}$ \\
\hline Proline (Pro) & $0.77 \pm 0.06^{b A}$ & $0.67 \pm 0.04^{b A}$ & $0.72 \pm 0.05^{b A}$ & $0.46 \pm 0.06^{a A}$ \\
\hline Asparagine (Asn) & $1.68 \pm 0.22^{b A}$ & $1.42 \pm 0.02^{b A}$ & $1.60 \pm 0.19^{b A}$ & $0.40 \pm 0.18^{a}$ \\
\hline Aspartic acid (Asp) & $1.55 \pm 0.20^{b A}$ & $1.38 \pm 0.09^{b A}$ & $1.38 \pm 0.09^{b A}$ & $0.72 \pm 0.03^{a B}$ \\
\hline Methionine (Met) & $2.95 \pm 0.27^{b A B}$ & $2.58 \pm 0.17^{a b A}$ & $2.56 \pm 0.19^{a b A}$ & $2.40 \pm 0.17^{a A}$ \\
\hline Glutamic acid (Glu) & $2.20 \pm 0.20^{b A}$ & $1.98 \pm 0.05^{b A}$ & $1.99 \pm 0.05^{b A}$ & $1.56 \pm 0.05^{a A}$ \\
\hline Phenylalanine (Phe) & $6.27 \pm 0.49^{b A B}$ & $5.18 \pm 0.31^{a A}$ & $5.10 \pm 0.27^{a A}$ & $4.64 \pm 0.34^{a A}$ \\
\hline Glutamine (GIn) & $3.61 \pm 0.22^{c A}$ & $3.42 \pm 0.20^{b c A}$ & $3.10 \pm 0.10^{b A}$ & $2.18 \pm 0.12^{a A}$ \\
\hline Lysine (Lys) & $5.05 \pm 0.84^{b A}$ & $4.36 \pm 0.13^{b A}$ & $5.12 \pm 0.60^{b A}$ & $3.08 \pm 0.10^{a A}$ \\
\hline Histidine (His) & $1.76 \pm 0.19^{b A}$ & $1.60 \pm 0.07 a b A$ & $1.71 \pm 0.06^{b A}$ & $1.36 \pm 0.07^{a A}$ \\
\hline Tyrosine (Tyr) & $4.77 \pm 0.40^{c B}$ & $3.88 \pm 0.22^{b A}$ & $3.64 \pm 0.14^{a b B}$ & $3.10 \pm 0.25^{a A}$ \\
\hline Tryptophan (Trp) & $2.66 \pm 0.27^{b A}$ & $2.21 \pm 0.17^{a A}$ & $2.18 \pm 0.12^{a A}$ & $1.90 \pm 0.14^{a A}$ \\
\hline Cystine (Cys) & $0.97 \pm 0.26^{a}$ & $1.01 \pm 0.02^{a}$ & $1.02 \pm 0.12^{a}$ & $0.82 \pm 0.05^{a}$ \\
\hline
\end{tabular}


released). Nevertheless, suboptimal intestinal conditions with reduced pancreatic and bile salts concentration coupled with an increase of residence time (E3) significantly reduced protein digestibility in both hard-boiled and omelet. Proteolysis experimented a reduction of 38 and $32 \%$ of the FAA released in hardboiled and omelet, respectively, under E3 GI conditions and compared to $\mathrm{C}$. This result evidences the role of matrix organization, the proteins from solid matrices (hard-boiled and omelet) hinder to a greater extent than semi-liquid matrices, the release and hydrolysis of proteins under suboptimal intestinal conditions ${ }^{44}$. Poached egg resulted in a liquid yolk and semi-solid white, which can be easily mixed with digestive fluids. In hard-boiled egg, both white and yolk acquired a solid structure, making the matrix degradation harder for its consequent hydrolyzation. In turn, omelet presents an emulsionlike structure of medium moisture in which protein network embeds lipids molecules and proteolysis has to occur before lipids can be made accessible to lipases ${ }^{45}$. The intrinsic molecular properties of the egg-proteins might determine enzyme accessibility, these properties being modified according to processing such as heat gelation. In fact, products with the same composition but different matrix structure can lead to different digestion patterns ${ }^{20}$. In turn, Asensio-Grau et al. (2018) ${ }^{23}$ reported a higher impact of egg cooking methods on the digestibility of proteins, lipids and xanthophylls bioaccessibility under exocrine pancreatic insufficiency (EPI) conditions than under healthy ones. Thus, poached favored egg protein digestion under EPI conditions compared to other methods, mainly due to its semi-liquid structure and lower degree of protein denaturation. 
The essential amino acids (EAA)/ non-essential amino acids (NEAA) ratio is also shown in Figure 5.3.2B. The EAA/NEAA ratio of cooked eggs digested under $C$ model ranged from 1.78 to 2.14 , this value being significantly lower in hard-boiled than in poached egg and omelet. Similar EAA/NEAA ratio was obtained from egg samples digested under E1 (oral alteration) and E2 (oral and gastric alterations) GI conditions. However, a considerable increase was found in samples digested mimicking the most suboptimal Gl conditions given in elders (E3 model). According to this result, elderly intestinal conditions might favor the essential amino acids release to a greater extent than the non-essential ones, even if the total proteolysis extent was reduced under E3 model. The predominant release of EAA than NEAA might be due to pancreatic enzymes specificity for certain peptide bonds ${ }^{46}$ this effect being more relevant under low enzymatic concentration (E3 model). The importance of EAA lies in muscle protein synthesis, as they are highly involved in this process ${ }^{47}$. Therefore, even if the total FAA achieved under the most critical scenery resulted in reductions, this result would be especially relevant for elders suffering from sarcopenia, especially for the qualitative (referred to more EAA than NEAA) more than quantitative (total FAA extent) protein consumption point of view.

Complementarily, Figure 5.3.2 shows the amino acidic contents (g amino acids/ $100 \mathrm{~g}$ of initial protein) of hydrophobic amino acids (HAA), positively charged amino acids (PCAA), negatively charged amino acids (NCAA), aromatic amino acids (AAA) and sulfur containing amino acids (SCAA)). The presence of HAA and PCAA in the samples, especially Tyr, Met, His and Lys have been found to improve 
the antioxidant properties of peptides. In turn, amino acids with a large side group such as tryptophan (AAA with an indolic group) and histidine (PCAA with an imidazole group), contribute to the antioxidant potential of peptides but in the case as hydrogen donors.

Additionally, peptides-lipid interactions can promote, or even improve, the antioxidant effects of peptides as a consequence of their hydrophobic properties ${ }^{46}$. Moreover, some of the PCAA are involved in up-regulation of genes involved in mitochondrial biogenesis, offering another mechanism for increased oxidation of long-chain fatty acids and glucose in insulin-sensitive tissues ${ }^{48}$. Likewise, methionine (with a SCAA character) besides histidine, serine and glycine are the major donors of 1-carbon groups ${ }^{48}$. In fact, diet supplementation with some NCAA, PCAA and SCAA (e.g., glutamine, arginine, and $\mathrm{N}$-acetyl-cysteine, respectively) are proposed for contributing to oxidative defense and immune function ${ }^{48}$. After digestion in C conditions, it is noticeable the higher presence of amino acids with hydrophobic character (HAA) (sum of alanine, valine, isoleucine, leucine, tyrosine, phenylalanine, tryptophan, proline, methionine and cysteine) in the amino acid profile (between 36 and $45.6 \mathrm{~g} \mathrm{HAA} / 100 \mathrm{~g}$ protein, corresponding to hard-boiled the greatest content compared to the other chemical groups. HAA content experimented, however, a notable decrease under E3 GI conditions in hard-boiled and omelet. In the opposite, sulfur containing amino acids (SCAA) (sum of cysteine and methionine) was the chemical group the least present (between 3.2 to $3.9 \mathrm{~g} / 100 \mathrm{~g}$ protein under $\mathrm{C}$ model), regardless the cooking methods or GI conditions. Slightly reductions on SCAA content in the three cooking methods were 169 
shown but only statistical effect of elderly GI conditions was found in poached and omelet. Regarding the positively (PCAA) and negatively (NCAA) charged as well as the aromatic (AAA) amino acids contents, values obtained under E3 model were significantly lower than those found in the amino acidic profile under $\mathrm{C}$ model in hard-boiled and omelet. However, the hard-boiled egg seems to provide greater amounts of almost all the chemical groups (excepting of SCAA), but also was the most affected sample by elderly alterations, with reductions up to $53 \%$ for NCAA under E3 GI conditions.

Besides the nutritional point of view, protein hydrolysates exert a positive impact on human health such as radical scavenging and reducing potential when large amounts of hydrophobic sulfur containing amino acids such as cysteine, histidine, tryptophan, tyrosine and phenylalanine are released ${ }^{32,49}$. The contribution of scavenging free radicals to human health promotion has been stated as delayers of associated oxidative damage to the physiological macromolecules. They play, therefore, a crucial role against cardiovascular, inflammatory and aging-induced degenerative diseases as well as cancers ${ }^{50}$.

\section{Effect of egg cooking on lipid digestibility in elders}

The molar percentages of acyl groups (AG) of the products derived from triglyceride hydrolysis (TG) after digestion are presented in Table 5.3.5 As expected, $90 \%$ of the total fat in cooked eggs was present as TG before digestion. After GI digestion under $\mathrm{C}$ conditions, lipolysis extent achieves values of 99.7, 95.6 and $94.9 \%$ for hardboiled, poached and omelet, respectively. The conversion due to the 
hydrolytic action of pancreatic lipase of TG was mainly into FFA with values of $77.23,80.92$ and $71.18 \%$ in hard-boiled, poached and omelet, respectively; followed by 1,2-DG, 2-MG, 1-MG and 1,3-DG. In omelet samples, fat globules could be trapped in a well-stable protein network resulting from mixing and the posterior thermal treatment. Thus, the protein enzymatic breakdown occur before lipids can be made accessible to lipases ${ }^{45}$. These lipid-protein interactions slow down the accessibility of enzymes to the substrate leading to lower conversion of TG into FFA together with lower matrix degradation compared to other methods ${ }^{23}$.

Regarding the elderly GI conditions and their effect on lipid digestion, nor oral, gastric and intestinal alterations negatively impact the absorbable fraction of hard-boiled, poached and omelet eggs. In fact, a significant increase $(p<0.05)$ was noted in $E 3$ with respect $C$ in poached egg. Nevertheless, the non-absorbable fraction was slightly, but significantly, reduced in hard-boiled and poached eggs, and therefore the total lipolysis extent. Therefore, a longer intestinal transit time would be responsible for exerting a positive effect on lipid digestion 51, even under reduced pancreatic lipase and bile concentrations (E3 model). 
(A)

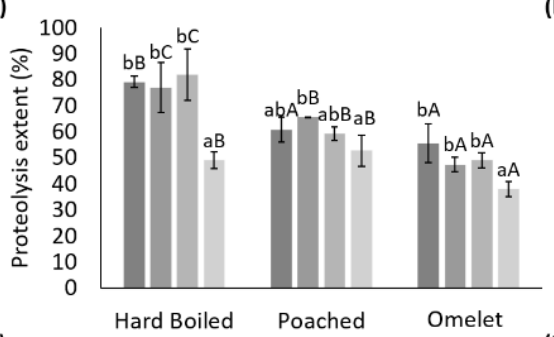

(C)

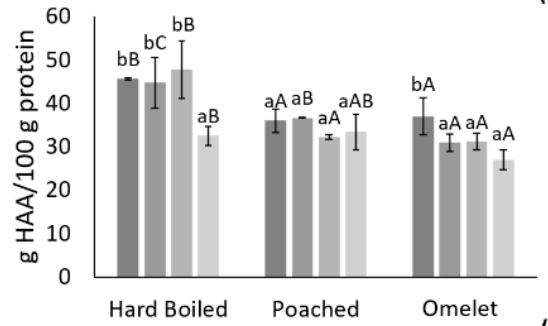

(E)

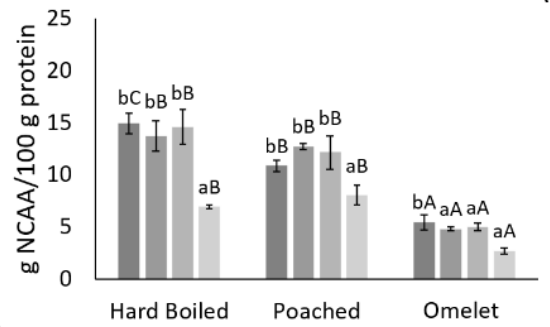

(G)

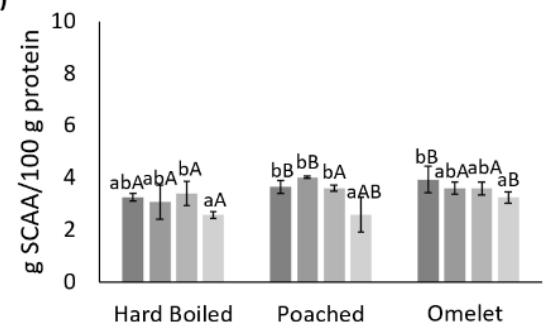

(B)

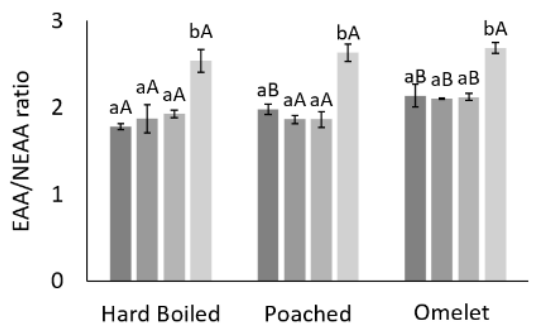

(D)

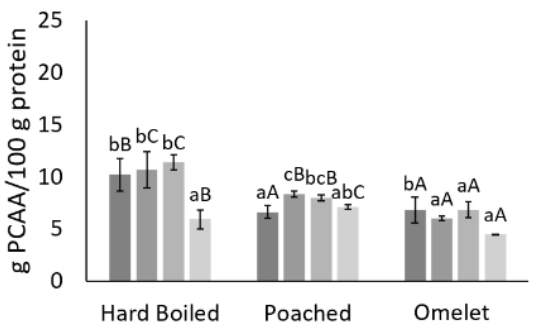

(F)

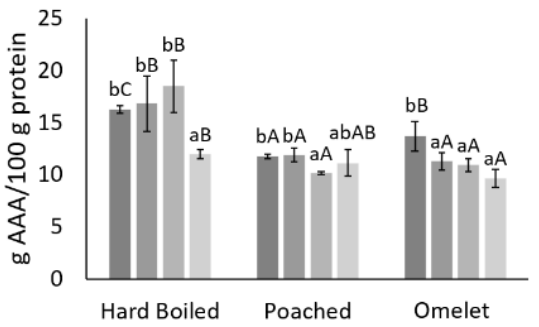

Figure 5.3.2. Proteolysis extent (\%) (g FAA's released/ $100 \mathrm{~g}$ protein) (A), essential and non-essential amino acids ratio (EAA/NEAA ratio) (B) and amino acids quantities ( $\mathrm{g} / 100 \mathrm{~g}$ of protein) classified by chemical structure (HHA (C), PCAA (D), NCAA (E), AAA (F) and SCAA (G)) found in hard-boiled, 
poached and omelet egg in vitro digested under C (control), E1 (Elderly 1 ), E2 (Elderly 2) and E3 (Elderly 3)) Gl conditions. EAA = (Val, Leu, lle, Thr, Met, Phe, Lys, His, Trp); NEAA = (Ala, Gly, Ser, Pro, Asn, Asp, Glu, Tyr, Cys). Hydrophobic amino acids (HAA = Ala, Val, Ile, Leu, Tyr, Phe, Trp, Pro, Met, Cys); Positively charged amino acids (PCAA = Lys, His); Negatively charged amino acids (NCAA = Asp, Asn, Glu, Gln); Aromatic amino acids (AAA = Phe, Trp, Tyr); Sulfur containing amino acids (SCAA = Cys, Met). Data shown are mean values from triplicates and the standard deviation. Different lowercase letters indicate significant differences between models and different capital letters indicate significant differences between cooking methods, with a significance level of $95 \%(p<0.05)$. 
Table 5.3.5. Molar Percentages of Acyl Groups (AG) Supported on the Different Glyceryl Backbone Structures (TG, 1,2$D G, 1,3-D G, 2-M G, 1-M G$ ) and Free Fatty Acids (FFA) and Cholesterol Content (mg/g Fat), Present in Non-digested (ND) and Digested Hard-boiled, Poached and Omelet Eggs. In Vitro GI Models: Control (C), Elderly 1 (E1), Elderly 2 (E2), Elderly 3 (E3) ${ }^{e}$

\begin{tabular}{|c|c|c|c|c|c|c|c|c|c|c|c|}
\hline $\begin{array}{l}\text { Cooking } \\
\text { method }\end{array}$ & $\begin{array}{l}\text { GI } \\
\text { cond. }\end{array}$ & $\mathrm{AG}_{\mathrm{Tg}}(\%)$ & $\mathrm{AG}_{1,2 \mathrm{DG}}(\%)$ & $A G_{1,3-D G}(\%)$ & $\mathrm{AG}_{2-\mathrm{MG}}(\%)$ & $\mathrm{AG}_{1-\mathrm{MG}}(\%)$ & FFA (\%) & $\begin{array}{l}\text { Absorbable } \\
\text { fraction }(\%)^{f}\end{array}$ & $\begin{array}{l}\text { Non-absorbable } \\
\text { fraction }(\%)^{g}\end{array}$ & $\begin{array}{l}\text { Lipolysis } \\
\text { extent (\%) }\end{array}$ & $\begin{array}{l}\text { Cholesterol } \\
\text { (mg/g fat) }\end{array}$ \\
\hline \multirow{5}{*}{$\begin{array}{l}\text { Hard- } \\
\text { boiled }\end{array}$} & ND & $89.57 \pm 2.10$ & - & - & - & $10.42 \pm 2.08$ & - & $10.43 \pm 2.10$ & - & $10.43 \pm 2.10$ & $54.14 \pm 2.92^{b A}$ \\
\hline & C & $0.32 \pm 0.26^{a A}$ & $12.84 \pm 0.44^{C A}$ & $1.021 \pm 0.002^{c B}$ & $5.61 \pm 0.18^{b B}$ & $3.00 \pm 0.31^{a B}$ & $77.23 \pm 0.06^{a B}$ & $85.83 \pm 0.18^{a C}$ & $13.86 \pm 0.44^{C B}$ & $99.68 \pm 0.27^{b c}$ & $50.91 \pm 4.91^{a b A E}$ \\
\hline & E1 & $0.30 \pm 0.07^{a A}$ & $11.81 \pm 0.06^{b A}$ & $0.84 \pm 0.09^{b B}$ & $5.70 \pm 0.10^{b B}$ & $2.87 \pm 0.20^{a B}$ & $78.97 \pm 1.04^{a B}$ & $87.55 \pm 0.74^{a c}$ & $12.66 \pm 0.03^{b A}$ & $100.20 \pm 0.78^{b c}$ & $47.82 \pm 4.22^{a b A}$ \\
\hline & E2 & $0.96 \pm 0.22^{a A}$ & $11.88 \pm 0.23^{b c B}$ & $0.53 \pm 0.06^{a B}$ & $6.15 \pm 0.27^{b B}$ & $3.12 \pm 0.02^{a B}$ & $78.09 \pm 1.16^{a B}$ & $87.36 \pm 1.41^{a B}$ & $12.41 \pm 0.17^{b A}$ & $99.77 \pm 1.24^{b B}$ & $46.65 \pm 7.18^{a b A}$ \\
\hline & E3 & $4.73 \pm 2.69^{\mathrm{b} A B}$ & $6.53 \pm 0.49^{a A}$ & $2.63 \pm 0.04^{d B}$ & $1.35 \pm 0.21^{a A}$ & $3.68 \pm 0.05^{b B}$ & $81.09 \pm 3.41^{a B}$ & $86.12 \pm 3.14^{a A B}$ & $9.15 \pm 0.45^{a A}$ & $95.27 \pm 2.69^{a A B}$ & $51.19 \pm 5.68^{a A}$ \\
\hline \multirow{5}{*}{ Poached } & ND & $89.98 \pm 0.29$ & - & - & - & $9.99 \pm 0.30$ & - & $10.02 \pm 0.29$ & - & $10.02 \pm 0.29$ & $56.39 \pm 2.81^{a A}$ \\
\hline & C & $4.41 \pm 0.42^{b B}$ & $11.16 \pm 0.44^{b c B}$ & $0.91 \pm 0.13^{a B}$ & $1.82 \pm 0.02^{b A}$ & $0.79 \pm 0.07^{b A}$ & $80.92 \pm 1.09^{a c}$ & $83.53 \pm 0.99^{a B}$ & $12.06 \pm 0.57^{b c A}$ & $95.59 \pm 0.42^{a B}$ & $60.31 \pm 4.06^{a B}$ \\
\hline & E1 & $2.40 \pm 0.19^{a B}$ & $12.46 \pm 0.27^{c B}$ & $1.00 \pm 0.03^{a c}$ & $1.46 \pm 0.06^{a A}$ & $0.49 \pm 0.09^{a A}$ & $82.19 \pm 0.20^{a c}$ & $84.14 \pm 0.05^{a B}$ & $13.46 \pm 0.24^{C B}$ & $97.60 \pm 0.19^{b B}$ & $63.08 \pm 4.48^{a B}$ \\
\hline & E2 & $2.01 \pm 0.88^{a A B}$ & $10.83 \pm 0.86^{b A}$ & $0.81 \pm 0.07^{a c}$ & $1.33 \pm 0.20^{a A}$ & $0.46 \pm 0.04^{a A}$ & $84.56 \pm 0.17^{b c}$ & $86.34 \pm 0.06^{b B}$ & $11.65 \pm 0.94^{b A}$ & $97.99 \pm 0.88^{b A B}$ & $58.69 \pm 8.46^{a A}$ \\
\hline & E3 & $2.32 \pm 0.39^{a A}$ & $8.99 \pm 0.04^{a B}$ & $0.82 \pm 0.02^{a A}$ & $1.78 \pm 0.04^{b B}$ & $0.61 \pm 0.07^{a b A}$ & $85.47 \pm 0.48^{b c}$ & $87.86 \pm 0.37^{c B}$ & $9.81 \pm 0.02^{a A}$ & $97.68 \pm 0.39^{b B}$ & $56.65 \pm 7.39^{a A}$ \\
\hline \multirow{5}{*}{ Omelet } & ND & $90.86 \pm 1.01$ & - & - & - & $9.63 \pm 1.09$ & - & $9.64 \pm 1.11$ & - & $9.64 \pm 1.11$ & $52.27 \pm 1.58^{b A}$ \\
\hline & C & $5.11 \pm 0.24^{a b B}$ & $13.06 \pm 0.02^{a b A}$ & $0.30 \pm 0.10^{a A}$ & $7.22 \pm 0.13^{c c}$ & $3.11 \pm 0.59^{a B}$ & $71.18 \pm 0.09^{a A}$ & $81.51 \pm 0.37^{a b A}$ & $13.37 \pm 0.13^{a B}$ & $94.89 \pm 0.24^{a A}$ & $45.29 \pm 0.86^{a b A}$ \\
\hline & E1 & $5.49 \pm 0.08^{b c}$ & $13.61 \pm 0.38^{b c}$ & $0.68 \pm 0.02^{a b A}$ & $6.22 \pm 0.07^{b c}$ & $3.10 \pm 0.04^{a B}$ & $71.67 \pm 0.50^{a b A}$ & $80.98 \pm 0.61^{a A}$ & $14.29 \pm 0.39^{a c}$ & $95.28 \pm 1.00^{a A}$ & $47.33 \pm 1.72^{a b A}$ \\
\hline & E2 & $3.90 \pm 1.10^{a B}$ & $11.97 \pm 0.37^{a B}$ & $0.29 \pm 0.12^{a A}$ & $7.03 \pm 0.28^{c c}$ & $3.64 \pm 0.12^{a c}$ & $73.21 \pm 1.02^{a b A}$ & $83.87 \pm 0.62^{b A}$ & $12.26 \pm 0.49^{a A}$ & $96.12 \pm 1.10^{a A}$ & $49.83 \pm 5.58^{a b A}$ \\
\hline & E3 & $4.28 \pm 0.09^{a b B}$ & $13.03 \pm 1.02^{a b c}$ & $0.93 \pm 0.39^{b A}$ & $4.11 \pm 0.38^{a c}$ & $3.38 \pm 0.61^{a B}$ & $74.27 \pm 1.74^{b A}$ & $81.76 \pm 1.50^{a b A}$ & $13.96 \pm 1.41^{a B}$ & $95.72 \pm 0.09^{a A}$ & $47.18 \pm 2.25^{a A}$ \\
\hline
\end{tabular}

$a, b, c, d$ Different lowercase letters indicate significant differences between models, with a significance level of $95 \%(p<0.05) .{ }^{A}, B, C$ Different capital letters indicate significant differences between cooking methods, with a significance level of $95 \%(p<0.05) .{ }^{e}$ Data shown are mean values from 
triplicates and the standard deviation. ${ }^{f}$ Absorbable fraction includes to $\mathrm{AG}_{2-\mathrm{MG}} \%+\mathrm{AG}_{1-\mathrm{MG}} \%+\mathrm{FFA} \%,{ }^{g}$ non-absorbable fraction to $A G_{1,2-\mathrm{DG}} \%+$ $\mathrm{AG}_{1,3-\mathrm{DG}} \%$ and ${ }^{h}$ lipolysis extent represent the summarize. 
Finally, cholesterol content (Table 5.3.5) of hard-boiled, poached and omelet eggs before digestion was similar. These results are in agreement with those reported by Hur et al. (2014) ${ }^{52}$, where the cholesterol content in pork patties was not affected by different cooking methods. However, cholesterol stability was slightly reduced in hard-boiled and omelet after in vitro digestion. The decreasing of cholesterol could be attributed to higher formation of cholesterol oxidation products during in vitro digestion 53 , being both physicochemical and enzymatic conditions, the oxidation promoters ${ }^{54}$. Also, microwave cooking ${ }^{52} \mathrm{might}$ be co-responsible of higher oxidative damage of cholesterol during the posterior GI digestion.

\section{Vitamins A and D3 bioaccessibility in eggs: impact of cooking and GI alterations in elders}

Figure 5.3.3 shows the Vitamin A and D3 bioaccessibility (\%) of hardboiled, poached and omelet eggs. Similarly to macronutrient digestibility, the structure matrix seems to be responsible, in a certain extent, to the differences found in terms of solubilization and micellar incorporation of the micronutrients. Hence, it was found the higher the complexity of structured food matrices (i.e., omelet), the minor the fat-soluble vitamins bioaccessibility present in the yolk ${ }^{23,55}$. Vitamin D3 bioaccessibility values under standardized GI conditions (C) agree with this behavior. Nevertheless, vitamin A bioaccessibility was higher in omelet than hard-boiled or poached eggs. Vitamin A has been reported to experiment oxidation along digestion leading to a reduced final concentration but increasing the presence of other compounds such as $\beta$-ionone, 2,2,6-trimethylcyclohexanone, $\beta$ - 
cyclocitral,(E)-5,6-epoxy- $\beta$-ionone, ionene, $\beta$-homocyclocytral and dihydroactinidiolide ${ }^{56}$. Hence, omelet structure could exert a protective effect on vitamin A against oxidation reactions and explain a higher vitamin A bioaccessibility in omelet than in hard-boiled and poached eggs.

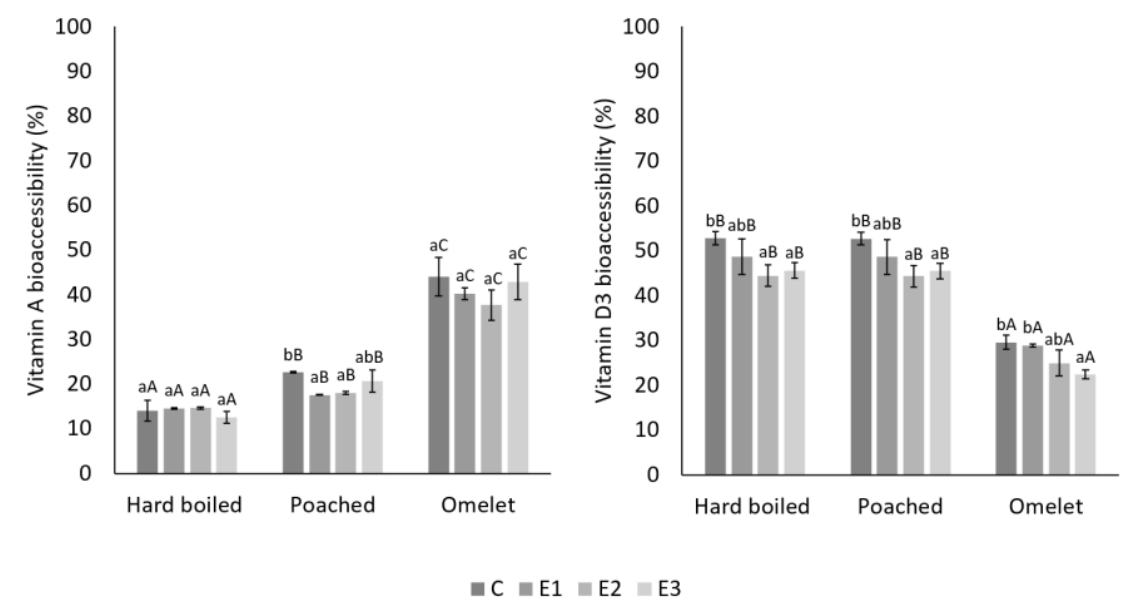

Figure 5.3.3. Vitamin A and D3 bioaccessibility achieved in hard-boiled, poached and omelet eggs in vitro digested under different $G$ l conditions (control (C), Elderly 1 (E1), Elderly 2 (E2), Elderly 3 (E3) models). Different lowercase letters indicate significant differences between models and different capital letters indicate significant differences between cooking methods, with a significance level of 95\% ( $p<0.05)$.

With respect to vitamins bioaccessibility under $\mathrm{Gl}$ conditions of elders (E1, E2 and E3), vitamin D3 release from all egg products was significantly reduced under E3 model conditions. However, no statistically significant differences were found in vitamin A 
bioaccessibility values achieved under $\mathrm{C}$ and $\mathrm{E} 3$ digestion conditions. Only vitamin A release from poached eggs seems to be negatively affected when oral and gastric conditions were suboptimal as in E1 and E2 simulations.

Liposoluble compounds release is dependent on their solubilization favored by bile acids presence. Thus, it was expected to obtain lower bioaccessibility values of both vitamins under reduced bile salts concentration occurring in E3 model. Nevertheless, only vitamin D3 was affected by this suboptimal intestinal condition ${ }^{57}$.

\section{Descriptive relationship among digestibility, egg cooking methods and elderly $\mathrm{GI}$ conditions}

A PCA was performed to assess the relationship between digestionend products from a descriptive point of view (Figure 5.3.4). Also, the component weights and the scores of hard-boiled, poached and omelet digested under the simulated GI conditions (C, E1, E2 and E3) are included. The first two principal components of the analysis explain $79.179 \%$ of the total variance of the digestibility in the samples (PC1: $57.105 \%$ and PC2: $22.074 \%$ ). By using the number of factor loads for two main components, it was identified which variables significantly affect the components $\mathrm{C} 1$ and $\mathrm{C} 2$. The vitamins bioaccessibility, lipolysis extent as well as the HHA, PCAA, NCAA and total (sum of the FAA released) proteolysis extents have the most significant impact on the value of the PC1. On the other hand, absorbable and non-absorbable lipid fractions, SCAA and EAA/NEAA ratio presented the most significant impact on the PC2 value. As a result, this procedure allows the analysis of the two-dimensional 


\begin{tabular}{|c|c|c|c|c|c|c|c|c|c|c|c|c|c|}
\hline & \multicolumn{13}{|c|}{ Component weights } \\
\hline & $\begin{array}{c}\text { EAA/NEAA } \\
\text { ratio }\end{array}$ & $\mathrm{HHA}$ & PCAA & NCAA & AAA & SCAA & $\begin{array}{l}\text { Proteolysis } \\
\text { extent (\%) }\end{array}$ & $\begin{array}{c}\text { Absorbable } \\
\text { lipid } \\
\text { fraction }\end{array}$ & $\begin{array}{c}\text { Non- } \\
\text { absorbable } \\
\text { lipid fraction }\end{array}$ & $\begin{array}{l}\text { Lipolysis } \\
\text { extent (\%) }\end{array}$ & $\begin{array}{c}\text { Vitamin A } \\
\text { bioaccessibility } \\
(\%) \\
\end{array}$ & $\begin{array}{c}\text { Vitamin D3 } \\
\text { bioaccessibility } \\
(\%)\end{array}$ & $\begin{array}{c}\text { Cholesterol } \\
\text { content }\end{array}$ \\
\hline PC1 & 0.244094 & $\begin{array}{l}-0.333529 \\
0.156462\end{array}$ & $\begin{array}{l}-0.349403 \\
0.119224\end{array}$ & $\begin{array}{l}-0.353422 \\
0.0202275\end{array}$ & $\begin{array}{l}-0.292559 \\
0.173945\end{array}$ & $\begin{array}{l}0.033893 \\
0.469093\end{array}$ & $\begin{array}{l}-0.355266 \\
0.139611\end{array}$ & $\begin{array}{l}-0.276361 \\
-0.346814\end{array}$ & $\begin{array}{c}0.0263643 \\
0.530864\end{array}$ & $\begin{array}{c}-0.32709 \\
0.00697399\end{array}$ & 0.305178 & -0.29662 & $\begin{array}{l}-0.0637065 \\
-0.213027\end{array}$ \\
\hline
\end{tabular}

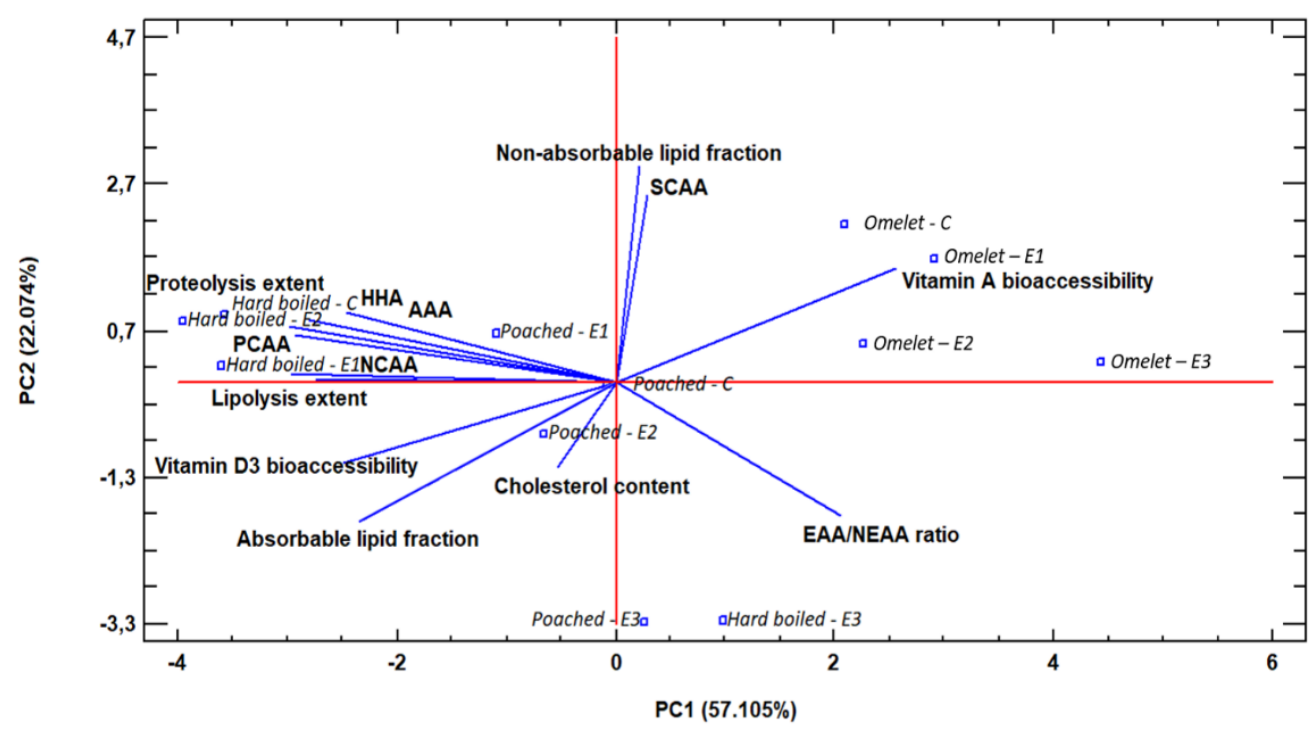

179
Figure 5.3.4. Biplot and component weights of the different end-digestion products of proteins (proteolysis extent, EAA/NEAA ratio, HAA, PCAA, NCAA, AAA and SCAA contents), lipids (cholesterol content, absorbable, non-absorbable and total lipolysis extents) and micronutrients (vitamin A and D3 bioaccessibility) and their association with the binomial cooked eggs (hard-boiled, poached and omelet)-GI conditions (C, E1, E2 and E3) obtained by means of a principal components analysis (PCA). 
space that was created based on the main components. In the score plot, the proximity between samples indicates similar behavior in terms of digestibility. In PC1, it is noted that omelet, located at the upper right side of the plot, exhibits different digestion pattern than hard-boiled and poached eggs, located at the left side of the plot. PC2 seems to distinguish vitamin $A$ bioaccessibility (higher in omelet) and samples with a higher EAA/NEAA ratio after digestion. Overall, PCA shows the narrow relationship between: proteolysis and lipolysis extents; the amino acids chemical classifications (excepting SCAA) with the proteolysis extent as well as the vitamin D3 bioaccessibility; and the absorbable lipid fraction and the cholesterol content with the lipolysis extent.

\section{CONCLUSIONS}

In sum, GI alterations appearing with aging negatively affect the ovoproteins digestibility with a reduction of up to $37 \%$ in the FAA released, compared with total FAA extents obtained under control conditions. Hard-boiled or poached method was more advisable than omelet preparation to maximize the proteolysis extent (sum of the FAA released) under elderly conditions. A notable increase in the release of essential amino acids, compared with the non-essential ones, was also noticed under simulated elderly GI conditions. Neither total lipolysis extent nor lipidic absorbable fraction is compromised with aging. Nevertheless, omelet preparation plays a significant role against the absorbable lipid fraction, mainly in free fatty acids release. Lastly, vitamin D3, lipolysis and proteolysis extents seem to be positively linked, especially in hard-boiled and poached eggs under 
elderly GI conditions. It could be stated that poached and omelet preparations might be more advisable, than hard-boiled, in terms of net supply of bioaccessible vitamin A for elders; while similar bioaccessible vitamin D3 content provided is very similar whatever the cooking method. Therefore, this study provides a better understanding of egg protein and lipids hydrolysis, together with liposoluble vitamins bioaccessibility, under $\mathrm{Gl}$ conditions of elderlies and as a function on cooking method. This information tries to contribute to establishing accurate dietary recommendations addressed to this population group. 


\section{REFERENCES}

(1) UN. World Population Prospects 2019: Highlights (St/Esa/Ser. A/423). 2019.

(2) Carew, H. T.; Zhang, W.; Rea, T. D. Chronic Health Conditions and Survival after Out-of-Hospital Ventricular Fibrillation Cardiac Arrest. Heart 2007, 93

(6),

728-731. https://doi.org/10.1136/hrt.2006.103895.

(3) Volkert, D.; Beck, A. M.; Cederholm, T.; Cruz-Jentoft, A.; Goisser, S.; Hooper, L.; Kiesswetter, E.; Maggio, M.; Raynaud-Simon, A.; Sieber, C. C.; Sobotka, L.; Van Asselt, D.; Wirth, R.; Bischoff, S. C. ESPEN Guideline ESPEN Guideline on Clinical Nutrition and Hydration in Geriatrics. 2018. https://doi.org/10.1016/j.clnu.2018.05.024.

(4) Morley, J. E. Frailty and Sarcopenia: The New Geriatric Giants. Revista de investigacion clinica 2016, 68 (2), 59-67.

(5) Shlisky, J.; Bloom, D. E.; Beaudreault, A. R.; Tucker, K. L.; Keller, H. H.; Freund-Levi, Y.; Fielding, R. A.; Cheng, F. W.; Jensen, G. L.; Wu, D.; Meydani, S. N. Nutritional Considerations for Healthy Aging and Reduction in Age-Related Chronic Disease. Advances in Nutrition: An International Review Journal 2017, 8 (1), 17.2-26. https://doi.org/10.3945/an.116.013474.

(6) Rémond, D.; Shahar, D. R.; Gille, D.; Pinto, P.; Kachal, J.; Peyron, M. A.; Dos Santos, C. N.; Walther, B.; Bordoni, A.; Dupont, D.; TomásCobos, L.; Vergères, G. Understanding the Gastrointestinal Tract of the Elderly to Develop Dietary Solutions That Prevent Malnutrition. Oncotarget 2015, 6 (16), 13858-13898. https://doi.org/10.18632/oncotarget.4030. 
(7) Rashid, I.; Tiwari, P.; Lehl, S. S. Malnutrition among Elderly a Multifactorial Condition to Flourish: Evidence from a Cross-Sectional Study. Clinical Epidemiology and Global Health 2019.

(8) Gilmartin, S.; O'Brien, N.; Giblin, L. Whey for Sarcopenia; Can Whey Peptides, Hydrolysates or Proteins Play a Beneficial Role? Foods 2020, 9 (6), 750. https://doi.org/10.3390/foods9060750.

(9) Peyron, M. A.; Santé-Lhoutellier, V.; François, O.; Hennequin, M. Oral Declines and Mastication Deficiencies Cause Alteration of Food Bolus Properties. Food and Function 2018, 9 (2), 1112-1122. https://doi.org/10.1039/c7fo01628j.

(10) Nagler, R. M.; Hershkovich, O. Age-Related Changes in Unstimulated Salivary Function and Composition and Its Relations to Medications and Oral Sensorial Complaints. Aging Clinical and Experimental Research 2005, 17 (5), 358-366. https://doi.org/10.1007/BF03324623.

(11) Salles, N. Basic Mechanisms of the Aging Gastrointestinal Tract. Digestive Diseases 2007, 25 (2), 112-117. https://doi.org/10.1159/000099474.

(12) Shani-Levi, C.; Alvito, P.; Andrés, A.; Assunção, R.; Barberá, R.; Blanquet-Diot, S.; Bourlieu, C.; Brodkorb, A.; Cilla, A.; Deglaire, A.; Denis, S.; Dupont, D.; Heredia, A.; Karakaya, S.; Giosafatto, C. V. L.; Mariniello, L.; Martins, C.; Ménard, O.; El, S. N.; Vegarud, G. E.; Ulleberg, E.; Lesmes, U. Extending in Vitro Digestion Models to Specific Human Populations: Perspectives, Practical Tools and BioRelevant Information. Trends in Food Science and Technology. Elsevier February 1, 2017, pp 52-63. https://doi.org/10.1016/j.tifs.2016.10.017. 
(13) Réhault-Godbert, S.; Guyot, N.; Nys, Y. The Golden Egg: Nutritional Value, Bioactivities, and Emerging Benefits for Human Health. Nutrients 2019, 11 (3), 684. https://doi.org/10.3390/nu11030684.

(14) Wang, X.; Qiu, N.; Liu, Y. Effect of Different Heat Treatments on In Vitro Digestion of Egg White Proteins and Identification of Bioactive Peptides in Digested Products. Journal of Food Science 2018, 83 (4), 1140-1148. https://doi.org/10.1111/1750-3841.14107.

(15) Phillips, S. M. Current Concepts and Unresolved Questions in Dietary Protein Requirements and Supplements in Adults. Frontiers in Nutrition. Frontiers Media S.A. May 8, 2017, p 13. https://doi.org/10.3389/fnut.2017.00013.

(16) Qureshi, A. I.; Suri, M. F. K.; Ahmed, S.; Nasar, A.; Divani, A. A.; Kirmani, J. F. Regular Egg Consumption Does Not Increase the Risk of Stroke and Cardiovascular Diseases. Medical Science Monitor 2006, 13 (1), CR1-CR8.

(17) Mattioli, S.; Dal Bosco, A.; Martino, M.; Ruggeri, S.; Marconi, O.; Sileoni, V.; Falcinelli, B.; Castellini, C.; Benincasa, P. Alfalfa and Flax Sprouts Supplementation Enriches the Content of Bioactive Compounds and Lowers the Cholesterol in Hen Egg. Journal of Functional Foods 2016, 22, 454-462. https://doi.org/10.1016/j.jff.2016.02.007.

(18) Bernhardt, S.; Schlich, E. Impact of Different Cooking Methods on Food Quality: Retention of Lipophilic Vitamins in Fresh and Frozen Vegetables. Journal of Food Engineering 2006, 77 (2), 327-333. https://doi.org/10.1016/j.jfoodeng.2005.06.040.

(19) Nyemb, K.; Guérin-Dubiard, C.; Pézennec, S.; Jardin, J.; Briard-Bion, 
V.; Cauty, C.; Rutherfurd, S. M.; Dupont, D.; Nau, F. The Structural Properties of Egg White Gels Impact the Extent of in Vitro Protein Digestion and the Nature of Peptides Generated. Food Hydrocolloids 2016, 54, 315-327. https://doi.org/10.1016/j.foodhyd.2015.10.011.

(20) Nyemb-Diop, K.; Causeur, D.; Jardin, J.; Briard-Bion, V.; GuérinDubiard, C.; Rutherfurd, S. M.; Dupont, D.; Nau, F. Investigating the Impact of Egg White Gel Structure on Peptide Kinetics Profile during in Vitro Digestion. Food Research International 2016, 88 (Part B), 302-309. https://doi.org/10.1016/j.foodres.2016.01.004.

(21) Somaratne, G.; Ye, A.; Nau, F.; Ferrua, M. J.; Dupont, D.; Paul Singh, R.; Singh, J. Egg White Gel Structure Determines Biochemical Digestion with Consequences on Softening and Mechanical Disintegration during in Vitro Gastric Digestion. Food Research International 2020, 138, 109782. https://doi.org/10.1016/j.foodres.2020.109782.

(22) Luo, Q.; Boom, R. M.; Janssen, A. E. M. Digestion of Protein and Protein Gels in Simulated Gastric Environment. LWT 2015, 63 (1), 161-168. https://doi.org/10.1016/j.lwt.2015.03.087.

(23) Asensio-Grau, A.; Peinado, I.; Heredia, A.; Andrés, A. Effect of Cooking Methods and Intestinal Conditions on Lipolysis, Proteolysis and Xanthophylls Bioaccessibility of Eggs. Journal of Functional Foods 2018, 46, 579-586. https://doi.org/10.1016/j.jff.2018.05.025.

(24) AOAC. Official Methods of Análisis. Association of Official Analytical Chemists. 15th Edition. 2000.

(25) Menezes, E. W.; de Melo, A. T.; Lima, G. H.; Lajolo, F. M. Measurement of Carbohydrate Components and Their Impact on 
Energy Value of Foods. Journal of Food Composition and Analysis 2004,

https://doi.org/10.1016/j.jfca.2004.03.018.

(26) Castaneda, N.; Lee, Y. Microstructure of a Model Fresh Cheese and Bioaccessibility of Vitamin D3 Using in Vitro Digestion. Gels 2019, 5 (1). https://doi.org/10.3390/gels5010016.

(27) Hernández-Olivas, E.; Muñoz-Pina, S.; Andrés, A.; Heredia, A. Impact of Elderly Gastrointestinal Alterations on in Vitro Digestion of Salmon, Sardine, Sea Bass and Hake: Proteolysis, Lipolysis and Bioaccesibility of Calcium and Vitamins. Food Chemistry 2020, 326. https://doi.org/10.1016/j.foodchem.2020.127024.

(28) Nieva-Echevarría, B.; Goicoechea, E.; Manzanos, M. J.; Guillén, M. D. Effects of Different Cooking Methods on the Lipids and Volatile Components of Farmed and Wild European Sea Bass (Dicentrarchus Labrax). Food Research International 2018, 103, 48-58. https://doi.org/10.1016/j.foodres.2017.10.029.

(29) Minekus, M.; Alminger, M.; Alvito, P.; Ballance, S.; Bohn, T.; Bourlieu, C.; Carrière, F.; Boutrou, R.; Corredig, M.; Dupont, D.; Dufour, C.; Egger, L.; Golding, M.; Karakaya, S.; Kirkhus, B.; Le Feunteun, S.; Lesmes, U.; Maclerzanka, A.; MacKie, A.; Marze, S.; McClements, D. J.; Ménard, O.; Recio, I.; Santos, C. N.; Singh, R. P.; Vegarud, G. E.; Wickham, M. S. J.; Weitschies, W.; Brodkorb, A. A Standardised Static in Vitro Digestion Method Suitable for Food-an International Consensus. Food and Function 2014, 5 (6), 1113-1124. https://doi.org/10.1039/c3fo60702j.

(30) Jalabert-Malbos, M. L.; Mishellany-Dutour, A.; Woda, A.; Peyron, M. A. Particle Size Distribution in the Food Bolus after Mastication of 
Natural Foods. Food Quality and Preference 2007, 18 (5), 803-812. https://doi.org/10.1016/j.foodqual.2007.01.010.

(31) Peinado, I.; Koutsidis, G.; Ames, J. Production of Seafood Flavour Formulations from Enzymatic Hydrolysates of Fish By-Products. LWT - Food Science and Technology 2016, 66, 444-452. https://doi.org/10.1016/j.lwt.2015.09.025.

(32) Uluko, H.; Zhang, S.; Liu, L.; Tsakama, M.; Lu, J.; Lv, J. Effects of Thermal, Microwave, and Ultrasound Pretreatments on Antioxidative Capacity of Enzymatic Milk Protein Concentrate Hydrolysates. Journal of Functional Foods 2015, 18, 1138-1146. https://doi.org/10.1016/j.jff.2014.11.024.

(33) Matt, D.; Veromann, E.; Luik, A. Effect of Housing Systems on Biochemical Composition.Pdf. Agronomy Research 2009, 7 (li), 662667.

(34) Miranda, J. M.; Anton, X.; Redondo-Valbuena, C.; Roca-Saavedra, P.; Rodriguez, J. A.; Lamas, A.; Franco, C. M.; Cepeda, A. Egg and EggDerived Foods: Effects on Human Health and Use as Functional Foods. Nutrients. MDPI AG January 20, 2015, pp 706-729. https://doi.org/10.3390/nu7010706.

(35) U.S. Department of Agriculture, A. R. S. FoodData Central.

(36) Seuss-Baum, I.; Nau, F.; Guérin-Dubiard, C. The Nutritional Quality of Eggs. In Improving the Safety and Quality of Eggs and Egg Products; Elsevier Ltd, 2011; Vol. 2, pp 201-236. https://doi.org/10.1533/9780857093929.3.201.

(37) Spanish Institute of Egg studies. El Gran Libro Del Huevo (in Spanish), 2009th ed.; Spanish Institute of Egg studies, Ed.; María del Mar 
Fernández, Amparo Lobato: Madrid, Spain, 2009.

(38) Nimalaratne, C.; Lopes-Lutz, D.; Schieber, A.; Wu, J. Effect of Domestic Cooking Methods on Egg Yolk Xanthophylls. Journal of Agricultural and Food Chemistry 2012, 60 (51), 12547-12552. https://doi.org/10.1021/jf303828n.

(39) Zasada, M.; Budzisz, E.; Kolodziejska, J.; Kalinowska-Lis, U. An Evaluation of the Physicochemical Parameters and the Content of the Active Ingredients in Original Formulas Containing Retinol. Journal of Cosmetic Dermatology 2020, jocd.13286. https://doi.org/10.1111/jocd.13286.

(40) Hemery, Y. M.; Fontan, L.; Moench-Pfanner, R.; Laillou, A.; Berger, J.; Renaud, C.; Avallone, S. Influence of Light Exposure and Oxidative Status on the Stability of Vitamins A and D3 during the Storage of Fortified Soybean Oil. Food Chemistry 2015, 184, 90-98. https://doi.org/10.1016/j.foodchem.2015.03.096.

(41) Haham, M.; Ish-Shalom, S.; Nodelman, M.; Duek, I.; Segal, E.; Kustanovich, M.; Livney, Y. D. Stability and Bioavailability of Vitamin D Nanoencapsulated in Casein Micelles. In Food and Function; 2012; Vol. 3, pp 737-744. https://doi.org/10.1039/c2fo10249h.

(42) Tsai, S. Y.; Lin, H. Y.; Hong, W. P.; Lin, C. P. Evaluation of Preliminary Causes for Vitamin D Series Degradation via DSC and HPLC Analyses. Journal of Thermal Analysis and Calorimetry 2017, 130 (3), 13571369. https://doi.org/10.1007/s10973-017-6209-4.

(43) Domínguez, R.; Borrajo, P.; Lorenzo, J. M. The Effect of Cooking Methods on Nutritional Value of Foal Meat. Journal of Food Composition and Analysis 2015, 43, 61-67. 
https://doi.org/10.1016/j.jfca.2015.04.007.

(44) Hernández-Olivas, E.; Muñoz-Pina, S.; Sánchez-García, J.; Andrés, A.; Heredia, A. Understanding the Role of Food Matrix on the Digestibility of Dairy Products under Elderly Gastrointestinal Conditions. Food Research International 2020, 137. https://doi.org/10.1016/j.foodres.2020.109454.

(45) Heredia, A.; Asensio-Grau, A.; Calvo-Lerma, J.; Andrés, A. Interactions Among Macronutrients and Their Effect on Lypolisis. In Bioaccessibility and Digestibility of Lipids from Food; Springer International Publishing, 2021; pp 151-168. https://doi.org/10.1007/978-3-030-56909-9_9.

(46) Aderinola, T. A.; Fagbemi, T. N.; Enujiugha, V. N.; Alashi, A. M.; Aluko, R. E. Amino Acid Composition and Antioxidant Properties of Moringa Oleifera Seed Protein Isolate and Enzymatic Hydrolysates. Heliyon 2018, 4 (10), e00877. https://doi.org/10.1016/j.heliyon.2018.e00877.

(47) Volpi, E.; Kobayashi, H.; Sheffield-Moore, M.; Mittendorfer, B.; Wolfe, R. R. Essential Amino Acids Are Primarily Responsible for the Amino Acid Stimulation of Muscle Protein Anabolism in Healthy Elderly Adults. American Journal of Clinical Nutrition 2003, 78 (2), 250-258. https://doi.org/10.1093/ajcn/78.2.250.

(48) Wu, G. Functional Amino Acids in Growth, Reproduction, and Health. Advances in Nutrition 2010, 1 (1), 31-37. https://doi.org/10.3945/an.110.1008.

(49) Udenigwe, C. C.; Aluko, R. E. Chemometric Analysis of the Amino Acid Requirements of Antioxidant Food Protein Hydrolysates. 
International Journal of Molecular Sciences 2011, 12 (5), 3148-3161. https://doi.org/10.3390/ijms12053148.

(50) Quansah, J. K.; Udenigwe, C. C.; Saalia, F. K.; Yada, R. Y. The Effect of Thermal and Ultrasonic Treatment on Amino Acid Composition, Radical Scavenging and Reducing Potential of Hydrolysates Obtained from Simulated Gastrointestinal Digestion of Cowpea Proteins. Plant Foods for Human Nutrition 2013, 68 (1), 31-38. https://doi.org/10.1007/s11130-013-0334-4.

(51) Lamothe, S.; Corbeil, M. M.; Turgeon, S. L.; Britten, M. Influence of Cheese Matrix on Lipid Digestion in a Simulated Gastro-Intestinal Environment. In Food and Function; The Royal Society of Chemistry, 2012; Vol. 3, pp 724-731. https://doi.org/10.1039/c2fo10256k.

(52) Hur, S. J.; Lee, S. Y.; Moon, S. S.; Lee, S. J. In Vitro Effects of Cooking Methods on Digestibility of Lipids and Formation of Cholesterol Oxidation Products in Pork. Korean Journal for Food Science of Animal Resources 2014, 34 (3), 280-286. https://doi.org/10.5851/kosfa.2014.34.3.280.

(53) Nieva-Echevarría, B.; Goicoechea, E.; Guillén, M. D. Food Lipid Oxidation under Gastrointestinal Digestion Conditions: A Review. Critical Reviews in Food Science and Nutrition. Taylor and Francis Inc. February 4, 2020, pp 461-478. https://doi.org/10.1080/10408398.2018.1538931.

(54) Hur, S.; Min, B.; Nam, K.; Lee, E.; Ahn, D. Effect of Dietary Cholesterol and Cholesterol Oxides on Blood Cholesterol, Lipids, and the Development of Atherosclerosis in Rabbits. International Journal of Molecular Sciences 2013, 14 (6), 12593-12606. https://doi.org/10.3390/ijms140612593. 
(55) Borel, P. Factors Affecting Intestinal Absorption of Highly Lipophilic Food Microconstituents (Fat-Soluble Vitamins, Carotenoids and Phytosterols). Clinical Chemistry and Laboratory Medicine. January 7, 2003, pp 979-994. https://doi.org/10.1515/CCLM.2003.151.

(56) Nieva-Echevarría, B.; Goicoechea, E.; Guillén, M. D. Polyunsaturated Lipids and Vitamin A Oxidation during Cod Liver Oil in Vitro Gastrointestinal Digestion. Antioxidant Effect of Added BHT. Food Chemistry 2017, 232, 733-743. https://doi.org/10.1016/j.foodchem.2017.04.057.

(57) Werner, A.; Kuipers, F.; Verkade, H. J. Fat Absorption and Lipid Metabolism in Cholestasis. In Madame Curie Bioscience Database [Internet]; Landes Bioscience, 2013. 
5.4 Chapter 4: Impact of common gastrointestinal disorders in elderly on in vitro meat protein digestibility and related properties.

Ever Hernández-Olivas, Sara Muñoz-Pina, Ana Andrés and Ana Heredia Submitted to Food Chemistry 2021. FOODCHEM-S-21-05613 


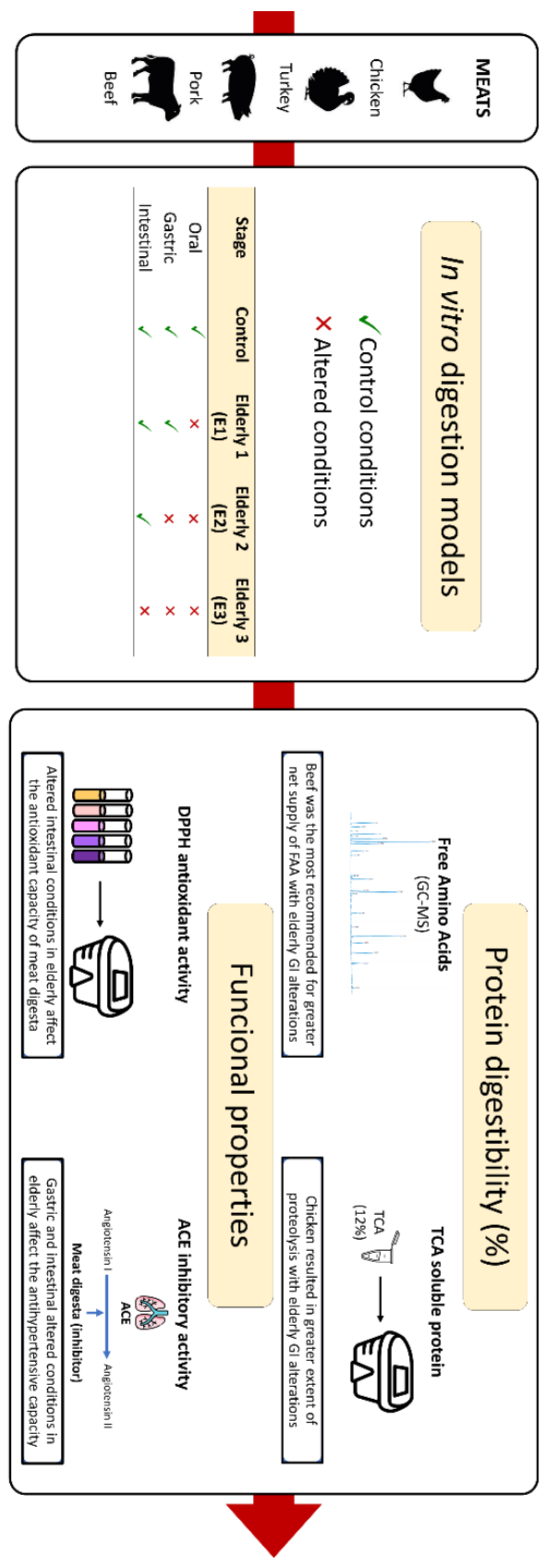




\section{Abstract}

This study aimed to in vitro evaluate the impact of common gastrointestinal (GI) alterations appearing with ageing on protein digestibility, and functional related-properties, in four different meats (chicken, turkey, pork and beef). Thus, three elderly digestion models were stated as long as altered GI conditions affected at oral (E1), oral and gastric (E3) and oral, gastric and intestinal stages (E3). Healthy adult GI conditions were also mimicked as standard control model (C). A notable TCA soluble protein and the FAA release reduction were found under intestinal suboptimal conditions (E3 model $(p<0.05)$ ), being more accuse in beef than in other meats. Thus, chicken intake would more advisable, than other meats, in terms of protein digestibility; while beef would provide a greater net supply of FAA under E3 model conditions. Gastric altered conditions, for its part, seems to favor protein solubility. Finally, while gastric and intestinal suboptimal conditions diminish the antihypertensive capacity of meat digesta, their antioxidant capacity was only negatively affected by intestinal altered conditions.

Keywords: aging; chicken; turkey; pork; beef; proteolysis; antihypertensive activity; antioxidant properties. 


\section{INTRODUCTION}

It is estimated that by 2050 a huge amount of the global population (2.1 billion) will be $>60$ years old ${ }^{1}$. Also, an increased life span implies a corresponding increase in aging-related disorders such as cardiovascular associated-diseases, cancer, obesity or diabetes. The increased oxidative stress as well as abnormalities in inflammatory responses, seem to drive the main etiologies of these aging-related diseases ${ }^{2}$. Thus, not only increasing life expectancy but also healthy aging are of growing global concern. Several factors affect how people get older, the role of diet being widely stated. The European Society for Clinical Nutrition and Metabolism advises elders to increase the consumption of rich-protein foods, and especially those rich in essential amino acids such as leucine or tryptophan ${ }^{3}$. Meat is one of the major protein sources providing all the body's essential amino acids, but it is also rich in some relevant micronutrients such as iron, zinc, selenium, and vitamins B6 and B12. Meat and its derivates generally provide high-quality protein with digestible indispensable amino acid scores (DIAAS) >100 regardless of processing ${ }^{4}$.

Nevertheless, the nutritional quality of proteins is also determined by its digestibility in the gastrointestinal tract, i.e., its protein digestion rate, shortchain peptides and amino acids bioavailability and functionality ${ }^{5}$. However, a decline of certain gastrointestinal (GI) functions (i.e. reduction or alteration of enzyme secretions, luminal electrolyte composition, motility and bile secretion, among others) could lead to macronutrient maldigestion and malabsorption, among which sarcopenia or protein deficit, stands out ${ }^{6}$. Besides, the poor oral health of elderlies can lead to inefficient mastication and the formation of oral boluses with bigger particles, which in the worst case can difficult swallowing and further digestion. Enddigestion products of proteolysis, most of these peptides, may exert 
antihypertensive, antioxidant, antimicrobial, opioid, immunomodulation and antithrombotic activities. However, peptides bioactive effect keeps latent until they would be motivated by the GI digestion or food processing, .i.e., drying, curing, fermentation and enzymatic hydrolysis ${ }^{7}$. Within the functional properties of bioactive peptides, the antihypertensive activity is assessed by the Angiotensin l-converting enzyme (ACE), a trans membrane peptidase, which is a key enzyme influencing the regulation of blood pressure. The antioxidant potential of peptides is dependent on their size as well as on the amino acidic composition ${ }^{7}$. These compounds would help to avoid the problems caused by oxidation and inflammation such as the developing of chronic diseases including cardiovascular disease, type II diabetes, hypertension and obesity.

In this context, this study aims at assessing proteolysis, the antihypertensive and antioxidant properties of peptides and free amino acids released after in vitro digestion of different types of meat (chicken, turkey, pork and beef) mimicking the most common gastrointestinal disorders appearing with aging.

\section{MATERIAL AND METHODS}

\section{Materials}

Raw meats (chicken breast, turkey breast, pork loin and beef entrecote) were purchased at a local store in Valencia (Spain). Pepsin from the porcine gastric mucosa (3200-4500 U/mg, $3602 \mathrm{U} / \mathrm{mg}$ ), pancreatin ( 8 x USP, 5.4 TAME $U / \mathrm{mg}$ ) from porcine pancreas, bile bovine (dried, unfractionated), analytical grade salts (potassium chloride, potassium dihydrogen phosphate, sodium bicarbonate, sodium chloride, magnesium chloride, ammonium carbonate, calcium chloride and potassium sulfate), boric acid, hydrochloric acid (37\%), sulfuric acid (95-97\%), sodium hydroxide, 
Angiotensin Converting Enzyme (ACE) from rabbit lung ( $\geq 2.0$ units/mg protein), N-Hippuric-His-Leu hydrate (HHL), ethyl acetate, 1,1-diphenyl-2picrylhydrazyl (DPPH) and ( \pm )-6-Hydroxy-2,5,7,8-tetramethylchromane-2carboxylic acid (Trolox) were obtained from Sigma-Aldrich Co. (St. Louis, MO, USA). Also, petroleum ether (VWR Chemicals, VWR International Pty. Ltd., Murarrie, Queensland, Australia), dichloromethane (HPLC grade > 99.8\%, Honeywell Fluka, Morris Plains, NJ, USA) and EZ-Faast amino acid kit (Phenomenex, Torrance, CA, USA) were used.

\section{Sample preparation}

Sliced meat ( $50 \pm 0.5 \mathrm{~g}$ ) were microwave cooked in a household microwave oven (model GW72N, Samsung Electronics Co. Ltd., Seoul, Korea) at $12 \pm 1$ $\mathrm{W} / \mathrm{g}$ for $120 \mathrm{~s}$ for chicken, turkey, pork and $75 \mathrm{~s}$ for beef.

\section{Physicochemical characterization of cooked meats}

Moisture, ash, fat and protein contents were determined in cooked meats according to the official methods 934.01, 942.05, 920.39 and $960.52^{8}$, respectively. In addition, cooked samples ( $0.015 \mathrm{~m}$ cubes, $3.375 \times 10^{6} \mathrm{~m}^{3}$ ) were analyzed through a texture profile analysis (TPA) using a TA.XT (Stable Micro System Ltd., God-alming, Surrey, UK) with a $50 \mathrm{~kg}$ load cell and an SMS P/75 probe by compressing $80 \%$. Hardness, cohesiveness, springiness, adhesiveness and chewiness were calculated based on the force-time deformation curves ${ }^{9}$.

\section{In vitro digestion simulation}

Cooked meats were in vitro digested under four GI conditions (Table 5.4.1). Three digestion models were defined to mimic the Gl alterations in elderlies at oral (E1), oral and gastric (E2), and oral, gastric and intestinal stages (E3) ${ }^{10}$. Besides, healthy adult GI conditions were also simulated as control (C) 
Table 5.4.1. GI parameters established at oral, gastric and intestinal stages for the control (C) and elderly models (E1, E2 and E3).

\begin{tabular}{|c|c|c|c|}
\hline $\begin{array}{c}\text { Digestion } \\
\text { model }\end{array}$ & Oral & Gastric & Intestinal \\
\hline Control (C) & $\begin{array}{c}5 \mathrm{~g} \text { of food sample }+5 \mathrm{~g} \text { human salivary } \\
\text { fluid } \\
\text { Chewing until a consistency like a tomato } \\
\text { or mustard paste ( } 30 \text { for all samples). }\end{array}$ & $\begin{array}{c}\text { Oral bolus }+10 \mathrm{~mL} \mathrm{SGF} \\
\mathrm{pH} 3 \\
\text { Pepsin }(2000 \mathrm{U} / \mathrm{mL}) \\
2 \mathrm{~h} \\
55 \mathrm{rpm} \\
37^{\circ} \mathrm{C}\end{array}$ & $\begin{array}{c}\text { Gastric chime }+20 \mathrm{~mL} \text { SIF } \\
\mathrm{pH} 7 \\
\text { Bile }(10 \mathrm{mM}) \\
\text { Pancreatin }(100 \mathrm{U} / \mathrm{mL}) \\
2 \mathrm{~h} \\
55 \mathrm{rpm} \\
37^{\circ} \mathrm{C}\end{array}$ \\
\hline $\begin{array}{c}\text { Elderly } \\
\text { (E1, E2 and E3) }\end{array}$ & $\begin{array}{c}5 \mathrm{~g} \text { of food sample }+5 \mathrm{~g} \text { human salivary } \\
\text { fluid } \\
\mathbf{5 0 \%} \text { of the Control chewing cycles }\end{array}$ & $\begin{array}{c}\text { Oral bolus + } 10 \mathrm{~mL} \mathrm{SGF} \\
\text { pH } 6 \\
\text { Pepsin (1500 U/mL) } \\
2 \mathrm{~h} \\
55 \mathrm{rpm} \\
37^{\circ} \mathrm{C}\end{array}$ & $\begin{array}{c}\text { Gastric chime }+20 \mathrm{~mL} \text { SIF } \\
\mathrm{pH} 7 \\
\text { Bile salts }(5 \mathrm{mM}) \\
\text { Pancreatin }(50 \mathrm{U} / \mathrm{mL}) \\
\mathbf{4} \mathbf{~ h} \\
55 \mathrm{rpm} \\
37^{\circ} \mathrm{C}\end{array}$ \\
\hline
\end{tabular}

Amendments included in the in vitro digestion models for elderlies, with respect to the control model (C), are highlighted in bold. E1 (alterations at oral stage); E2 (alterations at oral and gastric stages); E3 (alterations at oral, gastric and intestinal stages). 
model ${ }^{11}$. Concretely, altered gastric and intestinal conditions in elderlies were stated according to Shani-Levi et al. (2017) ${ }^{6}$. Oral stage was, however, in vivo performed by a volunteer with healthy dentition. Mastication cycles (30) were established to reach a bolus with similar consistency to that of a tomato or mustard paste. Once established, this parameter was reduced to $50 \%$ to mimic the most suboptimal oral conditions given in elderlies which results in large particle size of the bolus and making food digestion more difficult ${ }^{12}$.

Just before digestion experiments, gastric (SGF) and intestinal (SIF) digestion fluids were prepared from stock solutions and the enzymatic activity of pepsin and pancreatin previously tested according to Minekus et al. (2014) ${ }^{11}$. Aliquots were taken, if needed, after gastric digestion. After intestinal digestion, digesta was kept in an ice bath for 10 min to slow down the enzymatic activity before bioaccessible fraction separation (liquid phase) from the remaining solids by centrifugation at 4000 g-force for 5 min at 10 ${ }^{\circ} \mathrm{C}$.

\section{Analytical determinations in meat digesta}

\section{TCA soluble protein}

Protein hydrolysis was evaluated by measuring the protein soluble fraction in trichloroacetic acid (TCA) according to Lamothe et al. (2014) ${ }^{13}$. Briefly, $500 \mu \mathrm{L}$ of $36 \%$ TCA was added to $1000 \mu \mathrm{L}$ of the bioaccessible fraction to reach a final concentration of $12 \%(\mathrm{w} / \mathrm{w})$. The protein extract was prepared by mixing, incubating at 25 ㅇ $\mathrm{C}$ for $15 \mathrm{~min}$ on an Eppendorf Thermomixer Comfort (Eppendorf AG 22331, Hamburg, Germany), and centrifuging at $1200 \mathrm{~g}$-force for $10 \mathrm{~min}$. The supernatant was collected and diluted in 50 mM EDTA, $8 \mathrm{M}$ urea, pH 10 buffer. The ratio supernatant: buffer (v:v) was 1:9 and 1:99 extract for gastric and intestinal samples, respectively. Soluble 
protein in TCA was determined by measuring absorbance at $280 \mathrm{~nm}$ against a blank prepared with appropriate digestion fluids of each digestion model. TCA soluble protein ( $\mathrm{g} / 100 \mathrm{~g}$ of crude protein in cooked meat) was calculated by means of a calibration line of bovine serum albumin (BSA) as standard and agreed to eq. 5.13.

TCA soluble protein (\%)

$$
=\frac{(g \text { TCA soluble protein in bioccessible fraction })}{(g \text { crude protein in undigested cooked meat })} \times 100
$$

\section{Free amino acids released}

Free amino acids (essential and non-essential amino acids (EAA and NEAA)) resulting from protein digestion were determined through the protocol published by Hernández-Olivas et al. (2020) ${ }^{10}$. Thus, $100 \mu \mathrm{L}$ of postintestinal bioaccessible fraction were derivatized using the EZ-Faast amino acid kit and analyzed by GC-MS (Agilent Technologies, Injector 7683B series, Network GC System 6890N series, Inert Mass Selective Detector 5975 series, MSD ChemStation software). Norvaline was used as internal standard and the free amino acids (FAA) released (\%) during digestion calculated according to eq. 5.14 :

$$
F A A^{\prime} \text { 's released }(\%)=\frac{(g \text { FAA in bioaccessible fraction })}{(g \text { crude protein in undigested cooked meat })} \times 100
$$

Where: FAA's corresponds to the sum of the free amino acids in the bioaccessible fraction.

Angiotensin Converting Enzyme Inhibitory activity (ACE ia (\%)) 
ACE ia (\%) after gastric and intestinal digestion were measured according to Akillioğlu \& Karakaya (2009) ${ }^{14}$ with slight modifications. ACE reactive (25 $\mathrm{mU} / \mathrm{mL}$ ) and Hip-His-Leu (5 mM) as substrate were used for such purpose. Both solutions were prepared in $0.15 \mathrm{M}$ Tris base buffer, containing $0.3 \mathrm{M}$ $\mathrm{NaCl}$ and a $\mathrm{pH}$ adjusted at 8.3. Both digested samples $(40 \mu \mathrm{L})$ and ACE reactive $(100 \mu \mathrm{L})$ were incubated at $37{ }^{\circ} \mathrm{C}$ for 5 min and $100 \mu \mathrm{L}$ substrate was added. Incubation was continued for $30 \mathrm{~min}$ at the same temperature. Three controls (100 $\mu \mathrm{L} \mathrm{ACE}+40 \mu \mathrm{L}$ water; $140 \mu \mathrm{L}$ water; $40 \mu \mathrm{L}$ digesta +100 $\mu \mathrm{L}$ water) were also incubated as the digested samples. To stop the reaction, $150 \mu \mathrm{L}$ of $1 \mathrm{M} \mathrm{HCl}$ was added and mixed vigorously for 5 min. Ethyl acetate $(1000 \mu \mathrm{L})$ was added into tubes, and tubes were vortexed and centrifuged at $1200 \mathrm{~g}$-force for $10 \mathrm{~min}$, then $750 \mu \mathrm{L}$ of the supernatant were collected and put into clean tubes. Tubes were slowly shaken at $80{ }^{\circ} \mathrm{C}$ to evaporate ethyl acetate (approximately $20 \mathrm{~min}$ ). Solid hippuric acid remained in tubes was dissolved in $1 \mathrm{~mL}$ deionized water, and absorbance was measured at $228 \mathrm{~nm}$.

\section{Antioxidant activity (2,2-diphenyl-1-pricrilhidayil (DPPH))}

The antioxidant activity was measured in digesta according to Lamothe et al. (2014) ${ }^{13}$ with slight modifications. Briefly, 200 and $400 \mu \mathrm{L}$ of gastric and intestinal bioaccessible fractions, respectively, were mixed with $1000 \mu \mathrm{L}$ of 80:20 methanol:deionized water and shaked at $800 \mathrm{rpm}$ on an Eppendorf Thermomixer Comfort (Eppendorf AG 22331, Hamburg, Germany) for 60 $\min$ at 25 ㄷ. After that, the methanolic extract was centrifugated at 1200 g-force for $10 \mathrm{~min}$. Parallelly, 2,2-diphenyl-1-pricrilhidayil (DPPH) solution was prepared at a concentration of $35 \mathrm{mg} / \mathrm{L}$ to reach an absorbance of 1.1 \pm 0.02 . Following, $500 \mu \mathrm{L}$ of methanolic extracts were added to $1500 \mu \mathrm{L}$ of DPPH solution and allowed to react for 60 min with light absence. Finally, the absorbance was measured at $515 \mathrm{~nm}$ and antioxidant activity expressed 
as $\mathrm{mg} \mathrm{TE} / \mathrm{g}$ meat on a dry basis with the aid of a calibration curve of Trolox. Distilled water was used as the negative control and BHT as a positive control.

\section{Statistics}

Data were subjected to an analysis of variance (ANOVA) and the homogeneous groups were identified between in vitro models and type of meat by the LSD (Less Significant Difference) Fisher test. A principal component analysis (PCA) was also performed to understand the descriptive relationship among digestion-end-parameters (TCA soluble protein, data related to free amino acids released, ACE inhibitory activity and antioxidant capacity), meat origin (chicken and turkey, pork and beef) and host $\mathrm{GI}$ conditions (those of standard healthy adult (C) and of elderlies (E1, E2 and E3). Statgraphics Centurion XVII was used with a confidence level of $95 \%(p<0.05)$

\section{RESULTS AND DISCUSSION}

\section{Proximal composition and mechanical parameters of cooked meats}

The proximal composition of cooked meats in terms of water, protein, fat and ash contents (g/ $100 \mathrm{~g}$ ) is shown in Table 5.4.2. In general, values of proximal composition agreed with those reported in literature ${ }^{15}$. Higher water content was found in poultry meats as compared to pork and beef; as refers to ash content, pork, which has been reported to be a good source of iron, zinc and potassium, among others minerals presented the highest value (1.9 g/100 g). Besides ash content, the major differences in terms of composition were related to fat contents. Beef entrecote was richer in fat content $(10 \%)$ compared to the other studied cut of meats. Concretely, turkey breast has been stated as very low-fat meat. The protein/fat ratio is 
also found in Table 5.4.2, resulting much greater for turkey, without differences between the medium values of chicken and pork and the least value for beef.

The values of hardness, cohesiveness, springiness, adhesiveness and chewiness of the cooked meats are similar to those reported by Pematilleke et al. (2020) ${ }^{9}$ (Table 5.4.2). Meat composition (water, protein and fat) along with some cooking events such as water loss and fat drainage, muscle fiber shrinkage and protein coagulation ${ }^{9}$, could impact on textural properties in different extent. In this study, the greater protein along with the low water contents of turkey could be responsible of its higher cohesiveness. Actually, the protein/fat ratio resulted much greater in turkey than for the other type of meats, having thus, a correlation with the adhesiveness. Besides, Pematilleke et al. (2020) ${ }^{9}$ reports a lineal correlation between hardness and chewiness, suggesting that the number of chewing cycles required during mastication increases as long as the hardness does. Accordingly, the same number of cycles were stated for in vivo oral stage as statistical differences were found on neither the hardness nor the chewing as function on meat origin. Changes undergone by meat muscle during mastication such as particle size reduction pattern and saliva secretion, among others, are critical for protein digestibility. 
Table 5.4.2. Proximal composition ( $\mathrm{g} / 100 \mathrm{~g}$ of wet basis) and mechanical parameters of microwave-cooked chicken, turkey, pork and beef entrecote obtained from Textural Profile Analysis (TPA).

\begin{tabular}{|c|c|c|c|c|}
\hline & Chicken & Turkey & Pork & Beef \\
\hline \multicolumn{5}{|l|}{ Nutrient content } \\
\hline Water $(\mathrm{g} / 100 \mathrm{~g})$ & $64 \pm 2^{b}$ & $66.9 \pm 1.3^{b}$ & $60.0 \pm 0.6^{a}$ & $58 \pm 4^{a}$ \\
\hline Protein $(\mathrm{g} / 100 \mathrm{~g})$ & $28.5 \pm 0.3^{a}$ & $31.6 \pm 0.6^{a}$ & $34.3 \pm 0.7^{b}$ & $30 \pm 3^{a}$ \\
\hline Fat $(\mathrm{g} / 100 \mathrm{~g})$ & $3.6 \pm 0.9^{b}$ & $0.61 \pm 0.15^{\mathrm{a}}$ & $3.0 \pm 0.4^{b}$ & $10 \pm 2^{c}$ \\
\hline Ash (g/100 g) & $1.10 \pm 0.09^{b}$ & $0.83 \pm 0.10^{\mathrm{a}}$ & $1.90 \pm 0.09^{c}$ & $1.26 \pm 0.12^{b}$ \\
\hline Protein/fat ratio & $8 \pm 2^{b}$ & $52 \pm 14^{c}$ & $11.4 \pm 1.8^{\mathrm{b}}$ & $3.0 \pm 0.9^{a}$ \\
\hline \multicolumn{5}{|l|}{ Mechanical parameter } \\
\hline Hardness (N) & $237 \pm 51^{\mathrm{a}}$ & $213 \pm 23^{a}$ & $239 \pm 31^{a}$ & $279 \pm 36^{a}$ \\
\hline Cohesiveness & $0.61 \pm 0.04^{\mathrm{a}}$ & $0.69 \pm 0.04^{b}$ & $0.728 \pm 0.019^{b}$ & $0.65 \pm 0.03^{\mathrm{ab}}$ \\
\hline Springiness & $0.53 \pm 0.08^{\mathrm{a}}$ & $0.71 \pm 0.07^{b}$ & $0.70 \pm 0.05^{b}$ & $0.58 \pm 0.05^{a}$ \\
\hline Adhesiveness $\left(\mathrm{Ns}^{-1}\right)$ & $-0.075 \pm 0.020^{a}$ & $-0.047 \pm 0.013^{a}$ & $-0.069 \pm 0.018^{a}$ & $-0.08 \pm 0.03^{\circ}$ \\
\hline Chewiness (N) & $78 \pm 25^{\mathrm{a}}$ & $105 \pm 18^{a}$ & $122 \pm 21^{\mathrm{a}}$ & $107 \pm 22^{\mathrm{a}}$ \\
\hline
\end{tabular}

The data shown are mean values from triplicates and the standard deviation. ${ }^{\text {abc }}$ Different lowercase letters indicate significant differences between meats, with a significance level of $95 \%(p<0.05)$. 


\section{Digestive alterations in elders and meat protein digestibility}

The hydrolysis of meat proteins by gastro-intestinal enzymes was assessed after gastric and intestinal stages by measuring TCA soluble protein (mainly, smaller peptides and free amino acids) (Figure 5.4.1A). Additionally, as the post-intestinal aminoacidic profile was determined by GC-MS (Tables 5.4.3, 5.4.4, 5.4.5 and 5.4.6), the percentage of amino acids released after the gastrointestinal digestion is also presented in Figure 5.4.1B. Data reported in Figure 5.4.1 were normalized with respect to the protein content of the undigested cooked meats. As shown in Figure 5.4.1A, proteolysis mostly occurred at intestinal stage. After gastric digestion under $\mathrm{C}$ model, values ranged from 12 to $17 \mathrm{~g}$ TCA soluble protein/100 g protein for chicken and turkey, respectively. These values correspond to $16-29 \%$ of the total proteolysis achieved at the end of the GI digestion. Martini et al. (2019) ${ }^{16}$ found similar values in post-gastric digesta for the same type of meat. Partly, the low efficiency of pepsin could be consequence of the effect of cooking on meat muscle, since higher values of proteolysis in stomach has been found in raw meat. Thus, high cooking temperatures may promote protein aggregation and decrease protein hydrolysis by pepsin ${ }^{5}$. Indeed, in vitro static model can be also responsible of the poor gastric proteolysis, since gastric proteolysis extent achieved in vivo studies have been reported to be higher than in vitro ones ${ }^{17}$. Solubility of proteins highly depends on meat origin; while some proteins are highly soluble at normal gastric $\mathrm{pH}$, others could interact with other macromolecules, forming aggregates and becoming insoluble, slowing the protein breakdown and release ${ }^{18}$. Moreover, it has been reported that at normal gastric $\mathrm{pH}$ the acid present some ineffectiveness to open the structure to solubilization and enzyme action ${ }^{19}$. Remarkable high protein digestibility was achieved in chicken and beef (76 $\mathrm{g}$ of TCA soluble protein/ $100 \mathrm{~g}$ of protein) at the end of digestion, 
while pork protein seems to be less digestible (45 g of TCA soluble protein/ $100 \mathrm{~g}$ of protein) under $\mathrm{C}$ conditions. Rates of meat protein digestibility up to $95 \%$ have been reported in previous studies ${ }^{5}$. However, the hydrolysis of proteins depends on many meat factors such as matrix structure, the secondary structure of proteins resulting after processing (more $\beta$-sheet structure lead into lower digestibility), hydrophobicity (given by protein aggregation) or the possible disrupted cleavage sites of digestive enzymes (because lysine and arginine oxidation) which can enhance or limit proteolysis ${ }^{20}$. Also, lipid oxidation products (i.e. aldehydes), or reducing sugars could interact with proteins by means of Schiff bases ${ }^{5}$. The differences of protein solubility between meat types are coherent with FAAs values (g/ $100 \mathrm{~g}$ of protein) (Figure 5.4.2B) and agree with those previously reported by Martini et al. (2019) ${ }^{16}$. Thus, beef exhibited a significantly higher amount of FFAs released (66 g FAA/ $100 \mathrm{~g}$ protein) compared to pork, turkey and chicken (40.3, 53 and 43 g FAA/ 100 g protein, respectively) under $\mathrm{C}$ conditions. Gastric and duodenal enzymes degraded beef proteins more efficiently than proteins from pork, chicken and turkey. From Figures 5.4.1 $A$ and $B$, it is possible to affirm that beef and pork end-digestion products were totally found as free amino acids, while smaller peptides (30$35 \%$ of total proteolysis) would found in chicken and turkey intestinal digesta, together with free amino acids, regardless the $\mathrm{Gl}$ conditions. Previous studies found that myofibrillar proteins (55-60\%), particularly actin, titin and myosin, are hydrolysed more easily than sarcoplasmic (25$30 \%$ ) or stromal (10-15\%) proteins during in vitro digestion ${ }^{21}$. According to literature ${ }^{22}$, pork has less myofibrillar proteins (44\%, compared to $51-63 \%$ in other meats). Therefore, the protein composition of meat (myofibrillar:sarcoplasmic:stromal ratio) could be related to the lower protein digestibility in pork. 
In vitro simulation of altered GI conditions of elderlies discloses interesting information of protein hydrolysis of meats under this physiological scenario. Unexpectedly, $50 \%$ of chewing cycles reduction did not exert a statistically significant effect on protein digestion (comparison of $\mathrm{C}$ and $\mathrm{E} 1$ ). Apparently, particle size distribution decreases along digestion, digesta reaching a very similar particle size in stomach regardless the differences of the bolus in particle size. In this sense, Zou et al. (2018) ${ }^{23}$ report similar particle size distribution after in vitro gastric and intestinal digestion of different bolus with different particle size distribution from three types of pig muscles with different composition. With regards to the impact of gastric alterations on gastric proteolysis, it was also expected that a pH increasing from 3 to 6 together with a pepsin concentration reduction to $75 \%(1500 \mathrm{U} / \mathrm{mL})$, lessened the protein breakdown into smaller peptides and free amino acids. However, gastric alterations of elderlies mimicked in this study (model E2 and E3) resulted in an increase of gastric proteolysis in poultry meats, and especially in chicken. These results were not expected since pepsin has maximal hydrolytic activity between $\mathrm{pH} 1.5$ and 2.5 and activity is below $5 \%$ of the maximum above $\mathrm{pH}$ 5. Isoelectric point of proteins might be also considered and is maybe the key factor behind these results. As long as the digesta $\mathrm{pH}$ approaches the isoelectric point of proteins, aggregation and precipitation occur, hindering the access and efficiency of pepsin to the substrate and declining both protein solubility and hydrolysis during digestion ${ }^{24}$. The solubility of proteins increased as far as $\mathrm{pH}$ values moves from their isoelectric point ${ }^{21}$. At more alkaline $\mathrm{pH}$, for example at 6 (gastric $\mathrm{pH}$ in models E2 and E3) or 7 (intestinal $\mathrm{pH}$ ), proteins are increasingly negatively charged due to ionization of the carboxyl groups and deprotonation of the amine groups. As a result, electrostatic repulsion is enhanced, increasing protein-water interactions, and thereby protein solubility. Even though the minimum solubility of proteins occur at the isoelectric point of proteins, it has been reported that the solubility of 207 
myofibrillar proteins in chicken breast (the most abundant type) experiment a remarkable increase (from 10 to $80 \%$ ) when the $\mathrm{pH}$ rise from 5.5 to $6^{21}$. Reasonably, the variation in the amount of myofibrillar proteins among the types of meats (greater being for poultry meats) could be responsible for the greater gastric protein digestibility in chicken and turkey, than beef and pork. On the other hand, at $\mathrm{pH}$ values lower than 4.5 , and therefore at 3 , proteins are positively charged and electrostatic repulsion increased as well. $\mathrm{pH}$ buffering capacity of meats which is highly determined by food intrinsic factors (consistency, particle size, origin, protein and amino acid content and acid and base groups (such as salts and organic acids)) has also to be accounted. Like manner, food composition also impacts buffering capacity (i.e. foods with high fat and low protein contents lead to lower buffering capacity) ${ }^{25}$. Reasonably, beef highly differs from the other studied meats at fat content. This difference in composition could impair differences in terms of buffer capacity. It was noted that $\mathrm{pH}$ was more stable along digestion time in beef than in the other meats. The contribution of fat to buffering capacity of meats has been previously reported ${ }^{26}$. The higher lipidic content also could determine the action of micellization and emulsification promoting greater digestion of nutrients, not only of lipids but also of proteins. 

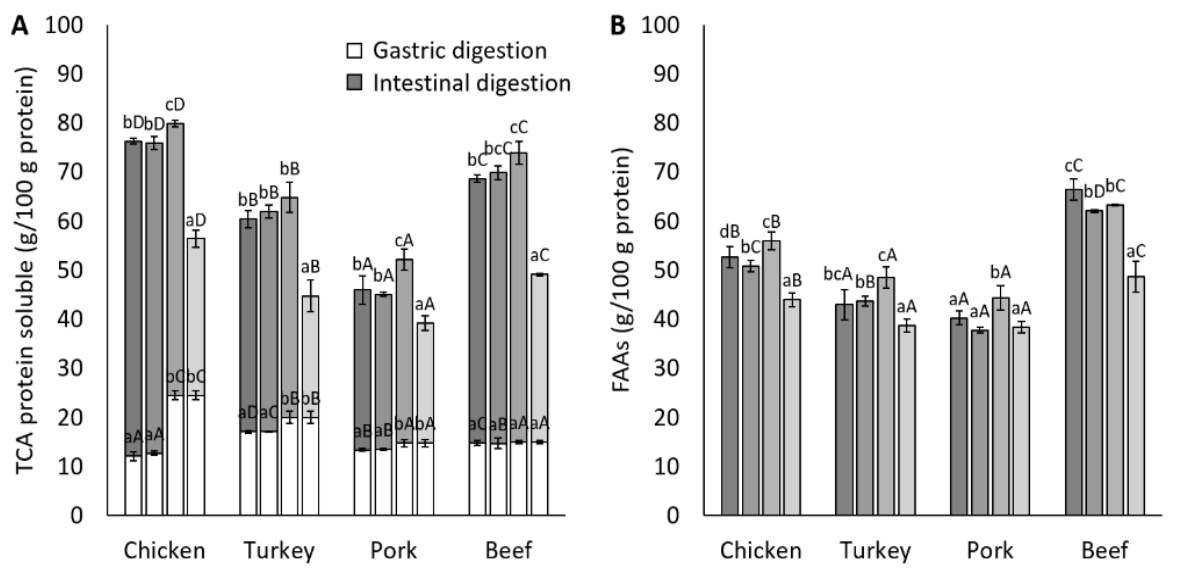

$\square C \square E 1 \quad \square E 2 \square E 3$

Figure 5.4.1. TCA soluble protein ( $\mathrm{g} / 100 \mathrm{~g}$ protein) of the bioaccessible fractions of gastric and intestinal digesta $(A)$ and the $F A A^{\prime}$ 's of bioaccessible fraction of intestinal digesta ( $\mathrm{g} / 100 \mathrm{~g}$ protein) (B) found in chicken, turkey, pork and beef in vitro digested under C (control), E1 (Elderly 1), E2 (Elderly 2) and $E 3$ (Elderly 3)) Gl conditions. The data shown are mean values from triplicates and the standard deviation. Different lowercase letters indicate significant differences between digestion models and different capital letters indicate significant differences between meat origin, with a significance level of $95 \%(p<0.05)$.

Regarding the proteolysis occurring later in the intestinal stage, the altered gastric model (E2) did not have a negative impact (Figure 5.4.1 A and B). Denis et al. (2016) ${ }^{27}$ found a delay of protein digestion kinetics but not on its extent, being even higher under in vitro senior $\mathrm{Gl}$ conditions. The activity of pancreatic proteases might compensate the gastric suboptimal conditions (E2) with the proteins conversion into peptides and free amino acids ${ }^{10}$. 


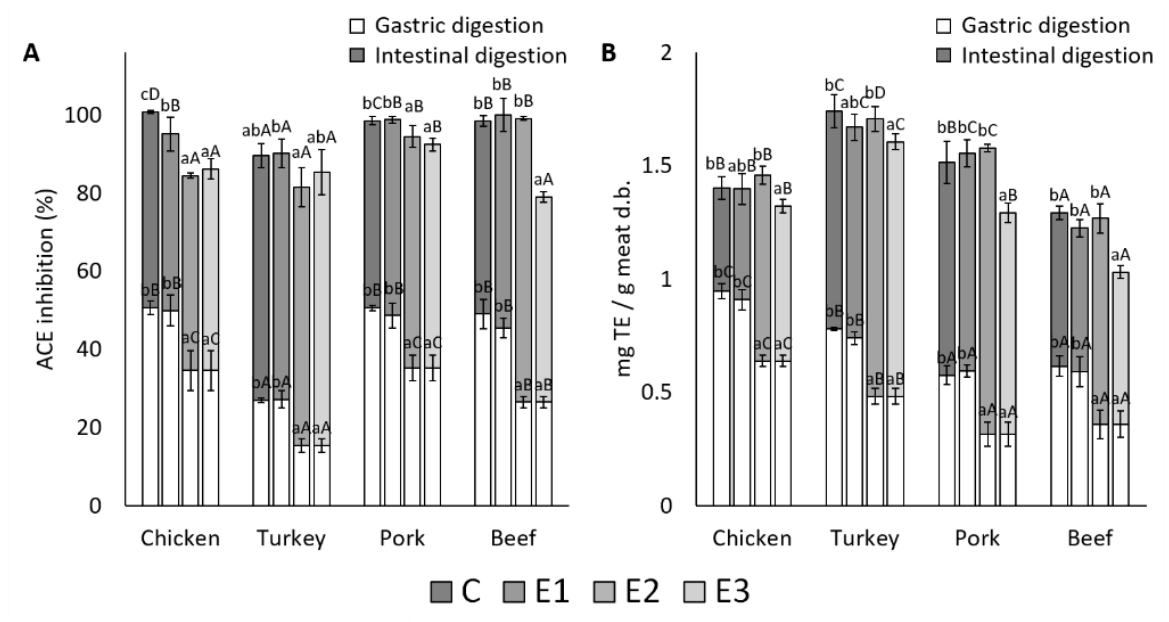

Figure 5.4.2. ACE inhibitory activity (\%) (A) and DPPH antioxidant activity (mg TE/ $g$ meat d.b.) (B) of the bioaccessible fractions of gastric and intestinal in vitro digesta of chicken and turkey, pork and beef under the elderly (E1, E2 and E3) and the standard GI conditions. The data shown are mean values from triplicates and the standard deviation. Different lowercase letters indicate significant differences between digestion models and different capital letters indicate significant differences between meat origin, with a significance level of $95 \%(p<0.05)$.

Finally, reduction of both pancreatic $(50 \mathrm{U} / \mathrm{mL})$ and bile salts $(5 \mathrm{mM})$ concentration, together with an extended duration (4h) of intestinal stage (model E3), significantly dropped proteolysis in all meats. However, digestibility was reduced in a variable extent depending on the type of meat. TCA soluble protein in intestinal digesta that informs about short-chain peptides and free amino acids with potential functional activities, experimented a reduction of 26, 26, 15 and $28 \%$ in chicken, turkey, pork and beef, respectively. If only FAAs released are considered, reduction of up to $16,10,5$ and $27 \%$ in chicken, turkey and beef, was found respectively. Thus, the altered intestinal conditions have a higher impact on short-chain 
peptides than on free amino acids released of chicken, turkey and pork meats.

A decrease in pancreatic enzymes secretion have been stated to lead with poor digestion and consequently to protein malabsorption causing nutritional deficiencies ${ }^{6}$. Again, it is important to note that in vivo proteolysis extent could be higher than in vitro static models, because of end-digestion products, not only from proteins but also from lipids, are not removed from the system. This effect being more noticeable as long as the intestinal time increases, and therefore in E3 model than in the others.

The individual amino acidic contents (g amino acids/ $100 \mathrm{~g}$ protein) as well as the essential amino acids (EAA)/non-essential amino acids (NEAA) ratio in the post-intestinal digesta are gathered in Tables 5.4.3, 5.4.4, 5.4.5 and 5.4.6. It is remarkable the great contents of free lysine, leucine and tyrosine, in the meat post-intestinal digesta (beef and chicken > turkey and pork). Leucine serves as substrate for the synthesis of new muscle proteins and as a signal to initiate the rate-limiting translation initiation step of MPS ${ }^{3}$. Lysine participates building muscle tissue but also collagen (an important constituent of cartilage, connective tissue and skin). Moreover, it is involved in the production of carnitine, which help to burn long-chain fatty acids producing energy ${ }^{28}$. Tyrosine has numerous functional roles such as the synthesis of neurotransmitters (catecholamines), alleviation of mental anxiety and depression and neutralization of free radicals ${ }^{29}$. 
Table 5.4.3. Amino acids profile ( $\mathrm{g} / 100 \mathrm{~g}$ protein) of intestinal digesta of chicken obtained under in vitro simulation of control (C) and elderly $\mathrm{Gl}$ conditions (E1, E2 and E3).

\begin{tabular}{|c|c|c|c|c|}
\hline \multirow{2}{*}{ Amino acid } & \multicolumn{4}{|l|}{ Chicken } \\
\hline & C & E1 & E2 & E3 \\
\hline Alanine (Ala) & $1.87 \pm 0.09^{\mathrm{bc}}$ & $1.84 \pm 0.08^{\mathrm{bc}}$ & $2.15 \pm 0.08^{\mathrm{cC}}$ & $1.61 \pm 0.02^{\mathrm{aC}}$ \\
\hline Glycine (Gly) & $0.679 \pm 0.014^{\mathrm{bC}}$ & $0.704 \pm 0.009^{b c}$ & $0.817 \pm 0.007^{c c}$ & $0.5028 \pm 0.0004^{\mathrm{ac}}$ \\
\hline$\alpha$-Aminobutyric acid (ABA) & - & - & - & - \\
\hline Valine (Val) & $2.99 \pm 0.14^{\mathrm{abB}}$ & $3.046 \pm 0.112^{\mathrm{bc}}$ & $3.45 \pm 0.03^{c c}$ & $2.872 \pm 0.010^{\mathrm{aD}}$ \\
\hline Leucine (Leu) & $7.0 \pm 0.2^{\mathrm{abB}}$ & $7.18 \pm 0.12^{\mathrm{bB}}$ & $7.9 \pm 0.3^{\mathrm{CB}}$ & $6.77 \pm 0.14^{\mathrm{aB}}$ \\
\hline Isoleucine (Ile) & $2.700 \pm 0.113^{\mathrm{abB}}$ & $2.81 \pm 0.07^{\mathrm{bc}}$ & $3.15 \pm 0.10^{\mathrm{CB}}$ & $2.64 \pm 0.06^{\mathrm{ac}}$ \\
\hline Threonine (Thr) & $1.48 \pm 0.05^{\mathrm{bc}}$ & $1.48 \pm 0.05^{\mathrm{bc}}$ & $1.692 \pm 0.012^{\mathrm{cc}}$ & $1.249 \pm 0.004^{\mathrm{ac}}$ \\
\hline Serine (Ser) & $1.22 \pm 0.04^{\mathrm{ac}}$ & $1.18 \pm 0.05^{\mathrm{ac}}$ & $1.34 \pm 0.02^{\mathrm{bB}}$ & - \\
\hline Proline (Pro) & $0.3992 \pm 0.0114^{\mathrm{aC}}$ & $0.416 \pm 0.009^{a c}$ & $0.504 \pm 0.008^{\mathrm{bc}}$ & $0.39 \pm 0.05^{\mathrm{aC}}$ \\
\hline Asparagine (Asn) & $1.10 \pm 0.07^{\mathrm{aB}}$ & $1.05 \pm 0.07^{\mathrm{aB}}$ & $1.10 \pm 0.04^{\mathrm{aB}}$ & - \\
\hline Aspartic acid (Asp) & $0.92 \pm 0.03^{b c}$ & $0.91 \pm 0.05^{b c}$ & $1.0279 \pm 0.0108^{c c}$ & $0.043 \pm 0.009^{\mathrm{aA}}$ \\
\hline Methionine (Met) & $1.80 \pm 0.06^{\mathrm{bB}}$ & $1.86 \pm 0.04^{\mathrm{bB}}$ & $2.05 \pm 0.03^{\mathrm{cB}}$ & $1.71 \pm 0.04^{\mathrm{aB}}$ \\
\hline Glutamic acid (Glu) & $3.6 \pm 0.3^{\mathrm{bB}}$ & $3.1 \pm 0.2^{\mathrm{bB}}$ & $3.4 \pm 0.5^{\mathrm{bc}}$ & $2.2 \pm 0.3^{\mathrm{ac}}$ \\
\hline Phenylalanine (Phe) & $3.65 \pm 0.06^{\mathrm{bBC}}$ & $3.82 \pm 0.06^{\mathrm{cc}}$ & $4.1 \pm 0.2^{\mathrm{cB}}$ & $3.4091 \pm 0.0011^{\mathrm{aB}}$ \\
\hline Glutamine (GIn) & - & - & - & - \\
\hline Ornithine (Orn) & $0.506 \pm 0.012^{\mathrm{bcD}}$ & $0.502 \pm 0.003^{b c}$ & $0.512 \pm 0.002^{c c}$ & $0.439 \pm 0.002^{\mathrm{aD}}$ \\
\hline Lysine (Lys) & $11.2 \pm 0.6^{\mathrm{cB}}$ & $8.6 \pm 0.2^{\mathrm{aB}}$ & $9.9 \pm 1.3^{\mathrm{abcA}}$ & $9.19 \pm 0.06^{\mathrm{bc}}$ \\
\hline Histidine (His) & $2.54 \pm 0.04^{b c}$ & $2.68 \pm 0.06^{\mathrm{cc}}$ & $3.01 \pm 0.12^{\mathrm{dc}}$ & $2.36 \pm 0.06^{\mathrm{ac}}$ \\
\hline Tyrosine (Tyr) & $4.71 \pm 0.10^{\mathrm{bc}}$ & $4.6 \pm 0.2^{\mathrm{bc}}$ & $4.58 \pm 0.13^{\mathrm{bc}}$ & $3.7 \pm 0.2^{\mathrm{aAB}}$ \\
\hline Tryptophan (Trp) & $2.76 \pm 0.07^{\mathrm{ac}}$ & $2.99 \pm 0.03^{b c}$ & $3.17 \pm 0.07^{\mathrm{dc}}$ & $2.595 \pm 0.114^{\mathrm{aB}}$ \\
\hline Cystine (C-C) & $1.63 \pm 0.04^{b c}$ & $1.87 \pm 0.03^{\mathrm{cB}}$ & $2.02 \pm 0.12^{\mathrm{dC}}$ & $1.20 \pm 0.06^{\mathrm{aB}}$ \\
\hline EAA/NEAA ratio & $2.24 \pm 0.03^{\mathrm{aB}}$ & $2.22 \pm 0.02^{\mathrm{ac}}$ & $2.3 \pm 0.2^{\mathrm{aB}}$ & $3.5 \pm 0.2^{\mathrm{bB}}$ \\
\hline Hydrophobic amino acids (HAA) & $27.9 \pm 0.8^{\mathrm{abB}}$ & $28.5 \pm 0.5^{\mathrm{bC}}(0)$ & $31.1 \pm 0.9^{c c}(0)$ & $26.4 \pm 1.2^{\mathrm{aB}}(5)$ \\
\hline Positively charged amino acids (PCAA) & $13.7 \pm 0.8^{b c}$ & $11.5 \pm 0.4^{\mathrm{aB}}(16)$ & $13.0 \pm 1.6^{\mathrm{abB}}(5)$ & $11.9 \pm 0.5^{\mathrm{ac}}(14)$ \\
\hline Negatively charged amino acids (NCAA) & $5.6 \pm 0.5^{\mathrm{bAB}}$ & $5.0 \pm 0.4^{\mathrm{bA}}(10)$ & $5.5 \pm 0.7^{\mathrm{bAB}}(1)$ & $2.1 \pm 0.4^{\mathrm{aA}}(63)$ \\
\hline Aromatic amino acids (AAA) & $11.12 \pm 0.02^{\mathrm{bc}}$ & $11.4 \pm 0.3^{\mathrm{bcc}}(0)$ & $11.9 \pm 0.5^{\mathrm{cc}}(0)$ & $10.0 \pm 0.5^{\mathrm{aB}}(10)$ \\
\hline Sulfur-containing amino acids (SCAA) & $3.43 \pm 0.10^{\mathrm{bc}}$ & $3.73 \pm 0.05^{\mathrm{cc}}(0)$ & $4.074 \pm 0.112^{\mathrm{dC}}(0)$ & $3.0 \pm 0.2^{\mathrm{aC}}(12)$ \\
\hline
\end{tabular}

Data shown are mean values from triplicates and the standard deviation. Values in parentheses represent the percentage (\%) of reduction of elderly $\mathrm{G}$ conditions (E1, E2 and E3) with respect to the control (C). Different lowercase letters indicate significant differences between digestion models and different capital letters indicate significant differences between meat origin in Tables 5.4.3. 5.4.4, 5.4 .5 and 5.4.6, with a significance level of 95\% 212 $(p<0.05)$. HAA = Ala, Val, lle, Leu, Tyr, Phe, Trp, Pro, Met, Cys; PCAA = Arg, Lys, His; NCAA = Asp, Asn, Glu, Gln; AAA = Phe, Trp, Tyr; SCAA = Cys, Met. 
Table 5.4.4. Amino acids profile (g/100 g protein) of intestinal digesta of turkey obtained under in vitro simulation of control (C) and elderly GI conditions (E1, E2 and E3).

\begin{tabular}{|c|c|c|c|c|}
\hline \multirow{2}{*}{ Amino acid } & \multicolumn{4}{|l|}{ Turkey } \\
\hline & C & E1 & E2 & E3 \\
\hline Alanine (Ala) & $1.45 \pm 0.08^{\mathrm{bB}}$ & $1.468 \pm 0.008^{\mathrm{bB}}$ & $1.90 \pm 0.10^{\mathrm{CB}}$ & $1.31 \pm 0.02^{\mathrm{aB}}$ \\
\hline Glycine (Gly) & $0.530 \pm 0.003^{\mathrm{bB}}$ & $0.572 \pm 0.006^{\mathrm{bB}}$ & $0.69 \pm 0.02^{\mathrm{CB}}$ & $0.408 \pm 0.014^{\mathrm{aB}}$ \\
\hline$\alpha$-Aminobutyric acid (ABA) & $0.113 \pm 0.010^{\mathrm{aB}}$ & $0.122 \pm 0.008^{\mathrm{aB}}$ & - & - \\
\hline Valine (Val) & $2.28 \pm 0.10^{\mathrm{aA}}$ & $2.35 \pm 0.03^{\mathrm{aB}}$ & $2.95 \pm 0.10^{\mathrm{bB}}$ & $2.43 \pm 0.06^{\mathrm{aB}}$ \\
\hline Leucine (Leu) & $5.39 \pm 0.19^{\mathrm{aA}}$ & $5.583 \pm 0.107^{\mathrm{aA}}$ & $6.70 \pm 0.14^{\mathrm{cA}}$ & $6.19 \pm 0.18^{\mathrm{bA}}$ \\
\hline Isoleucine (Ile) & $2.02 \pm 0.09^{\mathrm{aA}}$ & $2.09 \pm 0.04^{\mathrm{aB}}$ & $2.586 \pm 0.112^{\mathrm{bA}}$ & $2.25 \pm 0.13^{\mathrm{aA}}$ \\
\hline Threonine (Thr) & $1.20 \pm 0.05^{\mathrm{bB}}$ & $1.23 \pm 0.02^{\mathrm{bB}}$ & $1.54 \pm 0.05^{\mathrm{cB}}$ & $1.03 \pm 0.02^{\mathrm{aB}}$ \\
\hline Serine (Ser) & $1.07 \pm 0.05^{\mathrm{bB}}$ & $1.06 \pm 0.03^{\mathrm{bB}}$ & $1.33 \pm 0.06^{\mathrm{cB}}$ & $0.443 \pm 0.09^{a A}$ \\
\hline Proline (Pro) & $0.324 \pm 0.003^{\mathrm{bB}}$ & $0.341 \pm 0.002^{\mathrm{cB}}$ & $0.44 \pm 0.02^{\mathrm{dB}}$ & $0.30 \pm 0.02^{\mathrm{aB}}$ \\
\hline Asparagine (Asn) & $1.06 \pm 0.08^{\mathrm{aB}}$ & $1.06 \pm 0.04^{\mathrm{aB}}$ & $1.31 \pm 0.08^{\mathrm{bc}}$ & - \\
\hline Aspartic acid (Asp) & $0.79 \pm 0.02^{\mathrm{bB}}$ & $0.76 \pm 0.02^{\mathrm{bB}}$ & $0.93 \pm 0.07^{\mathrm{CB}}$ & $0.27 \pm 0.05^{\mathrm{aB}}$ \\
\hline Methionine (Met) & $1.34 \pm 0.15^{\mathrm{aA}}$ & $1.46 \pm 0.02^{\mathrm{aA}}$ & $1.76 \pm 0.04^{\mathrm{bA}}$ & $1.2 \pm 0.4^{\mathrm{aA}}$ \\
\hline Glutamic acid (Glu) & $2.2 \pm 0.3^{\mathrm{bA}}$ & $2.00 \pm 0.12^{\mathrm{bA}}$ & $2.4 \pm 0.3^{\mathrm{bB}}$ & $1.6 \pm 0.2^{\mathrm{aB}}$ \\
\hline Phenylalanine (Phe) & $2.87 \pm 0.05^{\mathrm{aA}}$ & $3.08 \pm 0.10^{\mathrm{aA}}$ & $3.48 \pm 0.05^{\mathrm{bA}}$ & $3.4 \pm 0.2^{\mathrm{bAB}}$ \\
\hline Glutamine (GIn) & $2.31 \pm 0.08^{\mathrm{aA}}$ & $2.38 \pm 0.12^{\mathrm{aB}}$ & - & - \\
\hline Ornithine (Orn) & $0.430 \pm 0.002^{\mathrm{bB}}$ & $0.432 \pm 0.010^{\mathrm{bcB}}$ & $0.447 \pm 0.006^{\mathrm{cA}}$ & $0.402 \pm 0.002^{\mathrm{aC}}$ \\
\hline Lysine (Lys) & $8.0 \pm 1.0^{\mathrm{bcA}}$ & $7.60 \pm 0.03^{\mathrm{bA}}$ & $8.6 \pm 0.6^{\mathrm{cA}}$ & $7.1 \pm 0.2^{\mathrm{aA}}$ \\
\hline Histidine (His) & $2.00 \pm 0.04^{\mathrm{aB}}$ & $2.15 \pm 0.07^{\mathrm{aB}}$ & $2.53 \pm 0.19^{\mathrm{bB}}$ & $2.4 \pm 0.2^{\mathrm{abc}}$ \\
\hline Tyrosine (Tyr) & $3.8 \pm 0.2^{\mathrm{aB}}$ & $4.1 \pm 0.4^{\mathrm{abBC}}$ & $4.2 \pm 0.5^{\mathrm{abc}}$ & $4.59 \pm 0.03^{b c}$ \\
\hline Tryptophan (Trp) & $2.22 \pm 0.10^{\mathrm{aB}}$ & $2.43 \pm 0.08^{\mathrm{aB}}$ & $2.71 \pm 0.04^{\mathrm{bB}}$ & $2.6 \pm 0.2^{\mathrm{abB}}$ \\
\hline Cystine (C-C) & $1.66 \pm 0.03^{b c}$ & $1.83 \pm 0.08^{\mathrm{CB}}$ & $1.90 \pm 0.02^{\mathrm{cc}}$ & $1.05 \pm 0.03^{\mathrm{aA}}$ \\
\hline EAA/NEAA ratio & $2.13 \pm 0.02^{\mathrm{aB}}$ & $2.09 \pm 0.08^{\mathrm{aB}}$ & $2.18 \pm 0.03^{\mathrm{aB}}$ & $2.8 \pm 0.3^{\mathrm{bA}}$ \\
\hline Hydrophobic amino acids (HAA) & $21.64 \pm 1.12^{\mathrm{aA}}$ & $22.9 \pm 0.9^{\mathrm{abB}}(0)$ & $26.7 \pm 0.9^{\mathrm{CB}}(0)$ & $24.50 \pm 1.09^{\mathrm{bB}}(0)$ \\
\hline Positively charged amino acids (PCAA) & $10.0 \pm 1.2^{\mathrm{abA}}$ & $9.3 \pm 0.8^{\mathrm{aA}}(7)$ & $11.2 \pm 0.9^{\mathrm{bAB}}(0)$ & $9.2 \pm 0.5^{\mathrm{aA}}(8)$ \\
\hline Negatively charged amino acids (NCAA) & $6.3 \pm 0.6^{\mathrm{cB}}$ & $6.2 \pm 0.3^{\mathrm{CB}}(2)$ & $4.7 \pm 0.6^{\mathrm{bA}}(26)$ & $2.05 \pm 1.10^{\mathrm{aA}}(68)$ \\
\hline Aromatic amino acids (AAA) & $8.9 \pm 0.4^{\mathrm{aB}}$ & $9.6 \pm 0.8^{\mathrm{abB}}(0)$ & $10.4 \pm 0.8^{\mathrm{bB}}(0)$ & $10.9 \pm 0.7^{\mathrm{bB}}(0)$ \\
\hline Sulfur-containing amino acids (SCAA) & $3.0 \pm 0.2^{\mathrm{bB}}$ & $3.29 \pm 0.12^{\mathrm{bB}}(0)$ & $3.66 \pm 0.07^{\mathrm{CB}}(0)$ & $2.2 \pm 0.4^{\mathrm{aB}}(25)$ \\
\hline
\end{tabular}

Data shown are mean values from triplicates and the standard deviation. Values in parentheses represent the percentage (\%) of reduction of elderly GI conditions (E1, E2 and E3) with respect to the control (C). Different lowercase letters indicate significant differences between digestion models and 213 different capital letters indicate significant differences between meat origin in Tables 5.4.3. 5.4.4, 5.4.5 and 5.4.6, with a significance level of 95\% $(\mathrm{p}<0.05)$. HAA = Ala, Val, lle, Leu, Tyr, Phe, Trp, Pro, Met, Cys; PCAA = Arg, Lys, His; NCAA = Asp, Asn, Glu, Gln; AAA = Phe, Trp, Tyr; SCAA = Cys, Met. 
Table 5.4.5. Amino acids profile ( $\mathrm{g} / 100 \mathrm{~g}$ protein) of intestinal digesta of pork obtained under in vitro simulation of control (C) and elderly $\mathrm{Gl}$ conditions (E1, E2 and E3).

\begin{tabular}{|c|c|c|c|c|}
\hline \multirow{2}{*}{ Amino acid } & \multicolumn{4}{|l|}{ Pork } \\
\hline & $\mathbf{C}$ & E1 & E2 & E3 \\
\hline Alanine (Ala) & $1.21 \pm 0.03^{\mathrm{cA}}$ & $1.13 \pm 0.02^{\mathrm{bA}}$ & $1.36 \pm 0.07^{\mathrm{dA}}$ & $1.04 \pm 0.03^{\mathrm{aA}}$ \\
\hline Glycine (Gly) & $0.404 \pm 0.012^{\mathrm{bA}}$ & $0.418 \pm 0.008^{\mathrm{bA}}$ & $0.494 \pm 0.016^{\mathrm{cA}}$ & $0.309 \pm 0.005^{\mathrm{aA}}$ \\
\hline$\alpha$-Aminobutyric acid (ABA) & $0.082 \pm 0.005^{\mathrm{aA}}$ & $0.097 \pm 0.005^{\mathrm{bA}}$ & $0.129 \pm 0.012^{\mathrm{cA}}$ & $0.125 \pm 0.004^{c A}$ \\
\hline Valine (Val) & $2.19 \pm 0.09^{\mathrm{aA}}$ & $2.06 \pm 0.07^{\mathrm{aA}}$ & $2.49 \pm 0.15^{\mathrm{bA}}$ & $2.10 \pm 0.12^{\mathrm{aA}}$ \\
\hline Leucine (Leu) & $5.5 \pm 0.2^{\mathrm{abA}}$ & $5.38 \pm 0.10^{\mathrm{aA}}$ & $6.4 \pm 0.5^{\mathrm{cA}}$ & $5.9 \pm 0.2^{\mathrm{bcA}}$ \\
\hline Isoleucine (Ile) & $2.076 \pm 0.110^{\mathrm{abA}}$ & $1.96 \pm 0.08^{\mathrm{aA}}$ & $2.35 \pm 0.15^{\mathrm{bA}}$ & $2.04 \pm 0.14^{\mathrm{abA}}$ \\
\hline Threonine (Thr) & $1.07 \pm 0.03^{\mathrm{bA}}$ & $1.02 \pm 0.05^{\mathrm{bA}}$ & $1.21 \pm 0.06^{\mathrm{cA}}$ & $0.93 \pm 0.03^{\mathrm{aA}}$ \\
\hline Serine (Ser) & $0.750 \pm 0.008^{\mathrm{cA}}$ & $0.70 \pm 0.02^{\mathrm{bA}}$ & $0.84 \pm 0.02^{\mathrm{dA}}$ & $0.515 \pm 0.016^{\mathrm{aA}}$ \\
\hline Proline (Pro) & $0.226 \pm 0.015^{\mathrm{bA}}$ & $0.2253 \pm 0.0108^{\mathrm{bA}}$ & $0.285 \pm 0.010^{\mathrm{CA}}$ & $0.1819 \pm 0.0006^{\mathrm{aA}}$ \\
\hline Asparagine (Asn) & $0.81 \pm 0.03^{\mathrm{cA}}$ & $0.72 \pm 0.03^{\mathrm{bA}}$ & $0.82 \pm 0.03^{\mathrm{cA}}$ & $0.40 \pm 0.03^{\mathrm{aA}}$ \\
\hline Aspartic acid (Asp) & $0.607 \pm 0.008^{\mathrm{bA}}$ & $0.6609 \pm 0.0013^{\mathrm{cA}}$ & $0.73 \pm 0.04^{\mathrm{dA}}$ & $0.469 \pm 0.004^{\mathrm{ac}}$ \\
\hline Methionine (Met) & $1.47 \pm 0.07^{\mathrm{abA}}$ & $1.42 \pm 0.03^{\mathrm{aA}}$ & $1.70 \pm 0.13^{\mathrm{bA}}$ & $1.49 \pm 0.07^{\mathrm{abA}}$ \\
\hline Glutamic acid (Glu) & $1.90 \pm 0.06^{\mathrm{bA}}$ & $1.73 \pm 0.15^{\mathrm{bA}}$ & $1.8 \pm 0.2^{\mathrm{bA}}$ & $1.14 \pm 0.02^{\mathrm{aA}}$ \\
\hline Phenylalanine (Phe) & $2.90 \pm 0.10^{\mathrm{aA}}$ & $3.00 \pm 0.05^{\mathrm{aA}}$ & $3.5 \pm 0.2^{\mathrm{bA}}$ & $3.26 \pm 0.13^{\mathrm{bA}}$ \\
\hline Glutamine (GIn) & $2.23 \pm 0.02^{\mathrm{cA}}$ & $2.07 \pm 0.06^{\mathrm{bA}}$ & $2.31 \pm 0.14^{\mathrm{cA}}$ & $1.924 \pm 0.013^{\mathrm{aA}}$ \\
\hline Ornithine (Orn) & $0.382 \pm 0.013^{\mathrm{bA}}$ & $0.381 \pm 0.006^{\mathrm{bA}}$ & $0.411 \pm 0.013^{\mathrm{cA}}$ & $0.3678 \pm 0.0005^{\mathrm{aB}}$ \\
\hline Lysine (Lys) & $9.1 \pm 0.2^{\mathrm{bA}}$ & $7.7 \pm 0.7^{\mathrm{aAB}}$ & $8.6 \pm 0.3^{\mathrm{bA}}$ & $8.96 \pm 0.14^{\mathrm{bB}}$ \\
\hline Histidine (His) & $1.62 \pm 0.10^{\mathrm{aA}}$ & $1.61 \pm 0.03^{\mathrm{aA}}$ & $2.05 \pm 0.09^{\mathrm{cA}}$ & $1.81 \pm 0.06^{\mathrm{bB}}$ \\
\hline Tyrosine (Tyr) & $3.0 \pm 0.2^{\mathrm{aA}}$ & $3.09 \pm 0.06^{\mathrm{aA}}$ & $3.41 \pm 0.12^{\mathrm{bB}}$ & $3.77 \pm 0.09^{\mathrm{cB}}$ \\
\hline Tryptophan (Trp) & $1.893 \pm 0.105^{\mathrm{aA}}$ & $1.99 \pm 0.05^{\mathrm{aA}}$ & $2.38 \pm 0.16^{\mathrm{cA}}$ & $2.15 \pm 0.07^{\mathrm{bA}}$ \\
\hline Cystine (C-C) & $0.76 \pm 0.05^{\mathrm{aA}}$ & $0.87 \pm 0.04^{\mathrm{aA}}$ & $1.04 \pm 0.03^{\mathrm{bA}}$ & - \\
\hline EAA/NEAA ratio & $2.87 \pm 0.10^{\mathrm{aD}}$ & $2.69 \pm 0.07^{\mathrm{aD}}$ & $2.84 \pm 0.09^{a c}$ & $3.64 \pm 0.04^{\mathrm{bB}}$ \\
\hline Hydrophobic amino acids (HAA) & $20.53 \pm 1.09^{\mathrm{aA}}$ & $20.3 \pm 0.5^{\mathrm{aA}}(1)$ & $23.8 \pm 1.7^{\mathrm{bA}}(0)$ & $21.6 \pm 1.0^{\mathrm{abA}}(0)$ \\
\hline Positively charged amino acids (PCAA) & $10.7 \pm 0.3^{\mathrm{bA}}$ & $8.82 \pm 1.12^{\mathrm{aA}}(18)$ & $10.7 \pm 0.4^{\mathrm{bA}}(0)$ & $10.6 \pm 0.3^{\mathrm{bB}}(1)$ \\
\hline Negatively charged amino acids (NCAA) & $5.54 \pm 0.02^{\mathrm{cA}}$ & $5.18 \pm 0.12^{\mathrm{bA}}(6)$ & $5.7 \pm 0.4^{\mathrm{bcB}}(0)$ & $3.91 \pm 0.07^{\mathrm{aB}}(29)$ \\
\hline Aromatic amino acids (AAA) & $7.8 \pm 0.5^{\mathrm{aA}}$ & $8.1 \pm 0.2^{\mathrm{aA}}(0)$ & $9.3 \pm 0.5^{\mathrm{bB}}(0)$ & $9.1 \pm 0.3^{\mathrm{bA}}(0)$ \\
\hline Sulfur-containing amino acids (SCAA) & $2.23 \pm 0.13^{\mathrm{bA}}$ & $2.30 \pm 0.09^{\mathrm{bA}}(0)$ & $2.7 \pm 0.2^{\mathrm{cA}}(0)$ & $1.47 \pm 0.07^{\mathrm{aA}}(34)$ \\
\hline
\end{tabular}

Data shown are mean values from triplicates and the standard deviation. Values in parentheses represent the percentage (\%) of reduction of elderly GI conditions (E1, E2 and E3) with respect to the control (C). Different lowercase letters indicate significant differences between digestion models 214 and different capital letters indicate significant differences between meat origin in Tables 5.4.3. 5.4.4, 5.4.5 and 5.4.6, with a significance level of 95\% $(p<0.05)$. HAA = Ala, Val, lle, Leu, Tyr, Phe, Trp, Pro, Met, Cys; PCAA = Arg, Lys, His; NCAA = Asp, Asn, Glu, Gln; AAA = Phe, Trp, Tyr; SCAA = Cys, Met. 
Table 5.4.6. Amino acids profile ( $\mathrm{g} / 100 \mathrm{~g}$ protein) of intestinal digesta of beef obtained under in vitro simulation of control (C) and elderly $\mathrm{Gl}$ conditions (E1, E2 and E3).

\begin{tabular}{|c|c|c|c|c|}
\hline \multirow{2}{*}{ Amino acid } & \multicolumn{4}{|l|}{ Beef } \\
\hline & C & E1 & E2 & E3 \\
\hline Alanine (Ala) & $3.4 \pm 0.2^{\mathrm{cD}}$ & $3.00 \pm 0.06^{\mathrm{bD}}$ & $3.1 \pm 0.3^{\mathrm{bcD}}$ & $2.17 \pm 0.03^{\mathrm{aD}}$ \\
\hline Glycine (Gly) & $0.97 \pm 0.09^{\mathrm{bD}}$ & $0.9040 \pm 0.0010^{\mathrm{bD}}$ & $0.92 \pm 0.06^{\mathrm{bD}}$ & $0.60 \pm 0.08^{\mathrm{aD}}$ \\
\hline$\alpha$-Aminobutyric acid (ABA) & $0.18 \pm 0.02^{\mathrm{bcc}}$ & $0.176 \pm 0.002^{\mathrm{bc}}$ & $0.195 \pm 0.008^{\mathrm{CB}}$ & $0.130 \pm 0.009^{\mathrm{aA}}$ \\
\hline Valine (Val) & $4.2 \pm 0.3^{\mathrm{cD}}$ & $3.90 \pm 0.05^{\mathrm{bD}}$ & $3.9 \pm 0.3^{\mathrm{bcD}}$ & $2.68 \pm 0.12^{\mathrm{ac}}$ \\
\hline Leucine (Leu) & $8.3 \pm 0.4^{\mathrm{cC}}$ & $7.6 \pm 0.2^{\mathrm{bc}}$ & $7.9 \pm 0.7^{\mathrm{bcB}}$ & $6.1 \pm 0.5^{\mathrm{aA}}$ \\
\hline Isoleucine (Ile) & $3.6 \pm 0.2^{\mathrm{bC}}$ & $3.26 \pm 0.08^{\mathrm{bD}}$ & $3.3 \pm 0.3^{\mathrm{bB}}$ & $2.43 \pm 0.06^{\mathrm{aB}}$ \\
\hline Threonine (Thr) & $2.6 \pm 0.3^{\mathrm{bD}}$ & $2.38 \pm 0.03^{\mathrm{bD}}$ & $2.4 \pm 0.2^{\mathrm{bD}}$ & $1.7 \pm 0.2^{\mathrm{aD}}$ \\
\hline Serine (Ser) & $2.3 \pm 0.2^{\mathrm{cD}}$ & $2.083 \pm 0.014^{\mathrm{bD}}$ & $2.1 \pm 0.2^{\mathrm{bcc}}$ & $0.58 \pm 0.02^{\mathrm{aB}}$ \\
\hline Proline (Pro) & $0.60 \pm 0.10^{\mathrm{bcD}}$ & $0.54 \pm 0.02^{\mathrm{bD}}$ & $0.69 \pm 0.03^{\mathrm{CD}}$ & $0.41 \pm 0.09^{\mathrm{ac}}$ \\
\hline Asparagine (Asn) & $2.3 \pm 0.2^{\mathrm{bc}}$ & $2.071 \pm 0.010^{\mathrm{bC}}$ & $2.0 \pm 0.2^{\mathrm{bD}}$ & $0.58 \pm 0.12^{\mathrm{aB}}$ \\
\hline Aspartic acid (Asp) & $1.91 \pm 0.14^{\mathrm{bD}}$ & $1.92 \pm 0.02^{\mathrm{bD}}$ & $1.77 \pm 0.10^{\mathrm{bD}}$ & $0.54 \pm 0.06^{\mathrm{aD}}$ \\
\hline Methionine (Met) & $2.26 \pm 0.10^{\mathrm{cc}}$ & $2.06 \pm 0.07^{b c}$ & $2.2 \pm 0.2^{\mathrm{bcB}}$ & $1.84 \pm 0.14^{\mathrm{aB}}$ \\
\hline Glutamic acid (Glu) & $8.0 \pm 0.7^{c c}$ & $6.8 \pm 0.2^{\mathrm{bC}}$ & $6.8 \pm 0.6^{\mathrm{bcD}}$ & $5.1 \pm 0.3^{\mathrm{aD}}$ \\
\hline Phenylalanine (Phe) & $3.5 \pm 0.2^{\mathrm{bB}}$ & $3.32 \pm 0.07^{\mathrm{abB}}$ & $3.4 \pm 0.2^{\mathrm{abA}}$ & $3.1 \pm 0.2^{\mathrm{aA}}$ \\
\hline Glutamine (GIn) & $4.0 \pm 0.3^{\mathrm{aB}}$ & $3.7 \pm 1.4^{\mathrm{aB}}$ & $3.6 \pm 0.3^{\mathrm{Ab}}$ & $3.6 \pm 0.9^{\mathrm{aB}}$ \\
\hline Ornithine (Orn) & $0.37 \pm 0.02^{\mathrm{bA}}$ & $0.36 \pm 0.09^{\mathrm{abAB}}$ & $0.37 \pm 0.03^{\mathrm{abA}}$ & $0.33 \pm 0.02^{\mathrm{aA}}$ \\
\hline Lysine (Lys) & $10.4 \pm 1.2^{\mathrm{aB}}$ & $9.74 \pm 0.02^{\mathrm{aC}}$ & $10.1 \pm 0.9^{\mathrm{aB}}$ & $10.6 \pm 0.9^{\mathrm{aD}}$ \\
\hline Histidine (His) & $1.9 \pm 0.2^{\mathrm{Bab}}$ & $2.1 \pm 0.6^{\mathrm{abABC}}$ & $2.11 \pm 0.10^{\mathrm{bA}}$ & $1.4 \pm 0.3^{\mathrm{aA}}$ \\
\hline Tyrosine (Tyr) & $2.3 \pm 0.6^{\mathrm{aA}}$ & $2.3 \pm 0.8^{\mathrm{aA}}$ & $2.311 \pm 0.114^{\mathrm{aA}}$ & $3.1 \pm 0.5^{\mathrm{aA}}$ \\
\hline Tryptophan (Trp) & $2.32 \pm 0.05^{\mathrm{aB}}$ & $2.4 \pm 0.8^{\mathrm{aABC}}$ & $2.5 \pm 0.2^{\mathrm{aAB}}$ & $2.3 \pm 0.3^{\mathrm{aAB}}$ \\
\hline Cystine (C-C) & $1.0 \pm 0.2^{\mathrm{aA}}$ & $1.3 \pm 0.6^{\mathrm{abAB}}$ & $1.492 \pm 0.009^{\mathrm{bB}}$ & - \\
\hline EAA/NEAA ratio & $1.724 \pm 0.004^{\mathrm{aA}}$ & $1.75 \pm 0.09^{\mathrm{aA}}$ & $1.78 \pm 0.03^{\mathrm{aA}}$ & $2.5 \pm 0.3^{\mathrm{bA}}$ \\
\hline Hydrophobic amino acids (HAA) & $30.5 \pm 0.8^{\mathrm{cC}}$ & $28.5 \pm 0.4^{\mathrm{bc}}(7)$ & $29.3 \pm 0.2^{\mathrm{bc}}(4)$ & $24.1 \pm 0.9^{\mathrm{aB}}(21)$ \\
\hline Positively charged amino acids (PCAA) & $12.3 \pm 0.4^{\mathrm{bB}}$ & $11.81 \pm 0.07^{\mathrm{aB}}(4)$ & $12.2 \pm 0.2^{\mathrm{bB}}(0)$ & $12.0 \pm 0.8^{\mathrm{abc}}(2)$ \\
\hline Negatively charged amino acids (NCAA) & $16.2 \pm 0.8^{\mathrm{cC}}$ & $14.5 \pm 0.7^{\mathrm{bc}}(11)$ & $14.19 \pm 0.02^{\mathrm{bC}}(13)$ & $10 \pm 2^{\mathrm{ac}}(40)$ \\
\hline Aromatic amino acids (AAA) & $8.13 \pm 0.07^{\mathrm{aA}}$ & $8.09 \pm 0.06^{\mathrm{aA}}(0)$ & $8.22 \pm 0.02^{\mathrm{aA}}(0)$ & $8.5 \pm 1.4^{\mathrm{aA}}(0)$ \\
\hline Sulfur-containing amino acids (SCAA) & $3.214 \pm 0.008^{\mathrm{bB}}$ & $3.35 \pm 0.02^{\mathrm{bB}}(0)$ & $3.66 \pm 0.04^{\mathrm{cB}}(0)$ & $1.8 \pm 0.2^{\mathrm{aB}}(43)$ \\
\hline
\end{tabular}

Data shown are mean values from triplicates and the standard deviation. Values in parentheses represent the percentage (\%) of reduction of elderly $\mathrm{GI}$ conditions (E1, E2 and E3) with respect to the control (C). Different lowercase letters indicate significant differences between digestion models and different 215apital letters indicate significant differences between meat origin in Tables 5.4.3. 5.4.4, 5.4.5 and 5.4.6, with a significance level of 95\% ( $p<0.05)$. HAA = Ala, Val, Ile, Leu, Tyr, Phe, Trp, Pro, Met, Cys; PCAA = Arg, Lys, His; NCAA = Asp, Asn, Glu, Gln; AAA = Phe, Trp, Tyr; SCAA = Cys, Met. 
Literature reports EAA/NEAA ratios between 0.6 and 0.9 depending on the type of meat and processing ${ }^{30,31}$. However, no values of this ratio after digestion were found in the literature. The EAA/NEAA ratio of cooked meats digested under C GI conditions were 1.68, 2.13, 2.24 and 2.87 for beef, turkey, chicken and pork, respectively, with EAA release being much more favored than NEAA release. The ratio EAA versus NEAA kept similar under E1 (oral alteration) and E2 (oral and gastric alterations) Gl conditions. Nevertheless, a considerable rise in the EAA/NEAA ratio value was found in samples digested mimicking the most suboptimal $\mathrm{Gl}$ conditions given in elderlies (E3 model). So, even when the extent of proteolysis (for both TCA soluble protein and for the sum of the FAA) was limited under the E3 model, elderly $\mathrm{GI}$ conditions might enhance the EAA release in a greater extent than the NEAA. The specificity of pancreatic enzymes for certain peptide bonds ${ }^{32}$ could be responsible of these results, being this chemical preference more noticed under suboptimal pancreatic concentrations. Most of amino acids involved in muscle synthesis are essential ones ${ }^{3}$, making these results of great interest to dietitians when addressing recommendations to elderlies and other individuals susceptible to suffer of sarcopenia.

Besides, amino acids have been chemically classified as hydrophobic amino acids (HAA= Ala, Val, Ile, Leu, Tyr, Phe, Trp, Pro, Met, Cys), positively charged amino acids (PCAA = Lys, His), negatively charged amino acids (NCAA = Asp, Asn, Glu, GIn), aromatic amino acids (AAA = Phe, Trp, Tyr) and sulfurcontaining amino acids (SCAA = Cys, Met) and their values reported as well. According to the obtained results, meat digesta were found to be richer in HAA than PCAA, AAA, NCAA and finally SCAA. The highest amount of HAA, PCAA and NCAA (mg/ $100 \mathrm{~g}$ of protein) was reported in digested chicken and beef, regardless the GI conditions; while very similar values of AAA and SCAA were found for all meat digesta. 
With regards to the effect of GI conditions on the different amino acid chemical groups, significant reduction was found under $\mathrm{E} 3 \mathrm{GI}$ conditions in chicken and beef compared to the $\mathrm{C}$ model. Concretely, the release of amino acids belonging to HAA, NCAA and SCAA were highly compromised by the suboptimal conditions at intestinal stage. Concretely, a decrease up to 21, 40 and $43 \%$ (respectively for HAA, NCAA and SCAA) was noticed in beef

under $\mathrm{E} 3$ with respect to those values achieved under $\mathrm{C}$. On the other hand, the concentration of the different amino acidic groups, excepting NCAA, were similar in turkey and pork digesta in the $\mathrm{C}$ and $\mathrm{E} 3$. The beneficial effect of amino acids, peptic fractions built-up of them, on consumer's health have been stated to be dependent on amino acids chemical classification. Concretely, end-digestion protein products can exert as hypertensive inhibitor, antioxidative, glucose uptake stimulating peptide, antithrombotic, anti-amnestic, dipeptidyl peptidase IV inhibitor, stomach mucosal membrane activity, regulators, dipeptidyl carboxypeptidase inhibitor. Both antihypertensive and antioxidant activities have been analyzed in this study and are discussed henceforth.

\section{Antioxidant and antihypertensive properties of meat bioaccessible fractions obtained under control and elderly GI conditions}

Bioaccessible fractions of post-gastric and post-pancreatic meat digesta were analyzed for their ACE-inhibitory (\%) and DPPH antioxidant (mg TE/g meat dry basis) capacities (Figure 5.4.2). According to the obtained results under C Gl conditions, only turkey digesta, both gastric and intestinal, would exert lower Angiotensin Converting Enzyme (ACE) inhibitory activity, compared to the other meats. The correlation between the release of health-promoting peptides and amino acids and antihypertensive activity ${ }^{33}$. In this sense, it has been reported that ACE-inhibitory activity increases as long as proteolysis progresses being higher at the end of digestion 
compared to post- gastric digesta. Nevertheless, the enzymatic action of pepsin, together with the optimal $\mathrm{pH}$, can be considered the keymechanism for bioactive peptides release along digestion as it can be deduced from the drastic reduction of ACE inhibitory capacity of gastric digesta in all meats when gastric conditions were suboptimal. Even if TCA soluble protein values after gastric digestion were similar in all meats, with the exception of chicken (Figure 5.4.1A), regardless the simulated GI conditions, the peptide profile and their molecular weight, both parameters involved in the biological activities, seems to be different under healthy and suboptimal GI conditions. At this point, the determination of peptidic fractions would be interesting as a reduction of molecular mass distribution of peptides from $5 \mathrm{kDa}$ to $1 \mathrm{kDa}$, or lower, has been reported to increase the ACE inhibitory activity ${ }^{33}$. Most blood pressure-lowering peptides have been found to be short sequences of 2-12 amino acids with Pro, Lys, Leu or aromatic residues preferably in any of the three positions close to the Cterminal site ${ }^{34}$. In contrast, larger peptides have been shown to exhibit difficulties in binding to the ACE active site, resulting in decreased inhibitory capacity ${ }^{35}$. The ACE inhibitory peptides contain hydrophobic amino acid at the N-terminal, as well as Trp at the C-terminal tripeptide sequence, which may contribute to ACE inhibitory activity. The hydrophobicity of peptides is assumed to contribute to their ACE-inhibitory activity and, furthermore, to their bioavailability ${ }^{36}$. On the other hand, only ACE inhibitory (\%) of intestinal digesta of beef experimented an additional significant reduction under E3 model compared to values achieved under E2 model. Therefore, the positive health-related benefits obtained from meat intake, excepting from beef, would be more compromised in elderlies with gastric suboptimal conditions compared to those elders suffering from intestinal insufficiency.

Concerning the antioxidant activity of digesta (Figure 5.4.2B) turkey, followed by pork, achieved the highest values ( $\mathrm{mg}$ of TE/ g dry matter) at 
the end of digestion standard under healthy $\mathrm{Gl}$ conditions (C). Protein hydrolysates might present different affinities for radicals resulting leading to synergistic and antagonistic effects at antioxidant level depending on meat origin ${ }^{37}$. Thus, Martini et al. (2019) ${ }^{16}$ reported the highest antiperoxidative activity against linoleic acid auto-oxidation, ABTS and hydroxyl radical scavenging for turkey and pork post-intestinal digesta; while beef digesta presented the least values. Moreover, it has been reported that in fatty-meats, such as beef, some peptides can be involved in the prevention of essential fatty acids peroxidation resulting in a reduced total antioxidant activity $^{38}$.

The relevance of the digestion events occurring at gastric stage is also notable on the antioxidant capacity of post-gastric digesta which underwent a drastic decrease under suboptimal gastric conditions, compared to under standard conditions.

As explained for the ACE-inhibitory capacity, gastric digesta obtained under $\mathrm{C}$ and $\mathrm{E} 1 \mathrm{Gl}$ conditions would present peptides with improved inhibitory potentials against the DPPH radicals compared to those obtained from E2 and $\mathrm{E} 3$ models. Bioactive peptides displaying antioxidant properties contain HAA and PCAA (notably, Tyr, Met, His and Lys). Also, aromatic amino acids (AAA) such as tryptophan, as well as those with positively charged character (PCAA) like histidine, exhibit high antioxidant capacity as hydrogen donors due to the presence of indolic and imidazole groups in AAA and PCAA, respectively. Since pepsin presents high preference for the $\mathrm{N}$-terminal of $A A A$, it is expected that this chemical group were hydrolysed at gastric level being available for bioabsorption before others. Certain PCAA seem to enhance the up-regulation of genes involved in the mitochondrial biogenesis, as an alternative pathway for long-chain fatty acids oxidation and glucose metabolism in insulin-sensitive tissues ${ }^{39}$. Similarly, methionine 
(belonging to SCAA) besides histidine, serine and glycine are the main contributors of 1-carbon groups. Actually, NCAA, PCAA and SCAA (e.g. glutamine, arginine and $\mathrm{N}$-acetyl-cysteine, respectively) are known to significantly contribute to the oxidative defense and immune function ${ }^{39}$.

Besides, gastric digesta from chicken exerted the highest antioxidant capacity. In this sense, chicken meat has been reported to be higher in bioactive imidazole dipeptides anserine ( $\beta$-alanyl-L-histidine) and carnosine ( $N$ - $\beta$-alanyl-1-methyl-L-histidine) which display high antioxidant capacity. Sarmadi \& Ismail (2010) ${ }^{40}$ have been reported to display high antioxidant activity. Even though the effect of gastric suboptimal conditions on gastric digesta's antioxidant capacity, only when alterations are also mimicked at intestinal level, a reduction of this property is found at the end of digestion. Therefore, the antioxidant capacity of the potential bioabsorbable fraction would decline when disfunctions appeared at both gastric and intestinal stages, their effect being more acute in poultry than mammals' meat. The hydrophobic properties of some amino acids can improve, or decrease, the antioxidant effect of peptides because of their interactions with lipids among others ${ }^{32}$. An increase of the digestion time could be responsible of a promotion of greater number of these reactions.

\section{Principal Component Analysis (PCA) applied to the obtained data}

Figure 5.4.3 shows the biplot coming from PCA and applied to the data obtained after gastric and intestinal digestion of the four meats under the different GI conditions (C, E1, E2 and E3). As it can be seen in Figure 5.4.3A, the two main components explain $88.930 \%$ of the variance of data at gastric stage (PC1: $58.227 \%$ and PC2: 30.703\%). PC1 clearly distinguishes between 

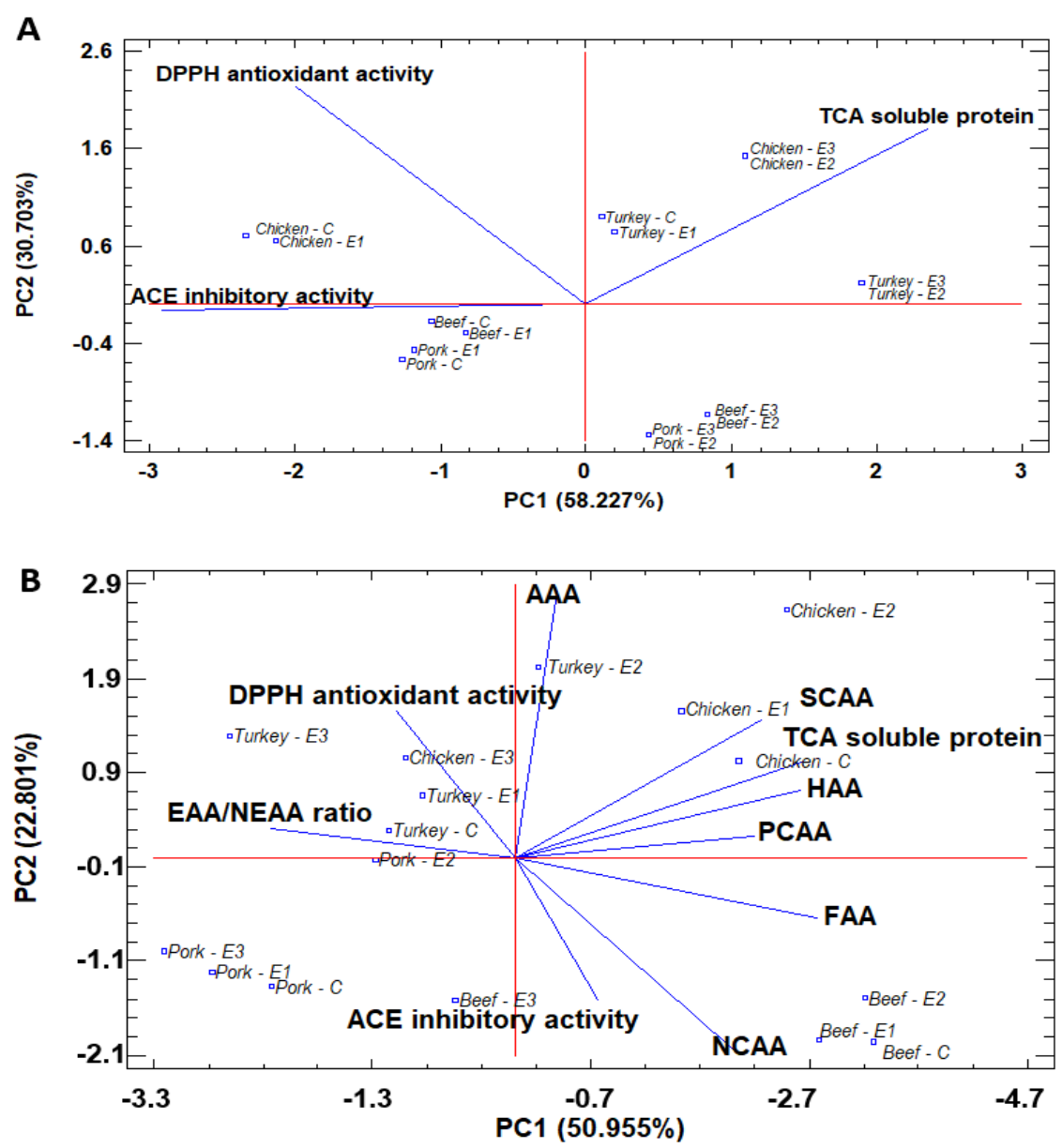

Figure 5.4.3. Biplot obtained by means of a principal component analysis (PCA) of the different gastric $(A)$ and intestinal $(B)$ end-digestion protein products and properties (FAA, EAA/NEAA ratio, HAA, PCAA, NCAA, AAA, SCAA, TCA soluble protein as well as ACE inhibition and DPPH antioxidant activities), and their association with the binomial meat type (chicken and turkey, beef and pork)-GI host conditions (C, E1, E2 and E3). 
Gl conditions, showing digesta of meat obtained under C and E1 GI conditions presented both higher ACE ia and antioxidant activity than digested obtained under E2 and E3, with the exception of turkey samples. Likewise, PC2 distinguishes among meats, being greater the TCA soluble protein and DPPH antioxidant activity in poultry than in pork or beef digesta. On the other hand, Figure $5.4 .3 \mathrm{~B}$ explains the $73.756 \%$ of the variance of data obtained at the end of intestinal digestion. PC1 (50.995\%) highlights the closed relationship and higher values of TCA soluble protein, free amino acids and ACE ia (\%) found for chicken and beef when intestinal conditions remain standard. Besides, DPPH antioxidant activity seems to be positively linked to the EAA/NEAA ratio. PC2 only represent the $22.801 \%$ of the variance of data, but evidences different among poultry and mamals' meat intestinal digesta as for gastric digesta.

\section{CONCLUSIONS}

Among the simulated gastrointestinal alterations appearing with aging, intestinal GI conditions were the only having a statistically significant negative effect on meat protein digestibility. Their effect was dependent on meat type. Contrarily to the expected, a $50 \%$ of chewing cycles reduction did not negative impact meat digestion. Reductions of up to 28 and $27 \%$ of TCA soluble protein and free amino acid released, respectively, were found in beef compared with total extents achieved under standard intestinal digestion conditions. Besides and unexpectedly a $50 \%$ reduction of chewing cycles did not hinder meat digestibility. Gastric alterations neither affected the protein breakdown, even being favored, mainly in chicken meat. According to that, chicken meat consumption would be more advisable than other meats to maximize the TCA soluble protein; while beef intake would result in more FAA release under elderly $\mathrm{GI}$ conditions. 
A notable increase in the release of essential amino acids, compared with the non-essential ones, was also noticed under simulated elderly GI conditions. Regarding the functional properties related to the protein enddigestion products, meats are highly recommended for their antioxidant and antihypertensive capacities. Both the gastric elderly alterations and the intestinal ones resulted in high reductions of meat digesta functionalities. Pork was more recommended to ensure maximum ACE inhibition against hypertension diseases in elders. Nevertheless, turkey meat digesta could exert more antioxidant benefits to people over 65 years. Therefore, this study provides a better understanding of protein digestion according to the type of meat, together with the functional properties related to the hydrolysis of proteins, under oral, gastric and intestinal suboptimal conditions of elderlies. This data may contribute to the establishment of more accurate dietary recommendations concerning meat consumption and addressed to this population group. 


\section{REFERENCES}

(1) United Nations. World Population Prospects 2019: Highlights | Multimedia Library - United Nations Department of Economic and Social Affairs. United Nations. 2019.

(2) Chakrabarti, S.; Jahandideh, F.; Wu, J. Food-Derived Bioactive Peptides on Inflammation and Oxidative Stress. BioMed Research International. 2014. https://doi.org/10.1155/2014/608979.

(3) Volpi, E.; Kobayashi, H.; Sheffield-Moore, M.; Mittendorfer, B.; Wolfe, R. R. Essential Amino Acids Are Primarily Responsible for the Amino Acid Stimulation of Muscle Protein Anabolism in Healthy Elderly Adults. American Journal of Clinical Nutrition 2003, 78 (2), 250-258. https://doi.org/10.1093/ajcn/78.2.250.

(4) Bailey, H. M.; Mathai, J. K.; Berg, E. P.; Stein, H. H. Most Meat Products Have Digestible Indispensable Amino Acid Scores That Are Greater than 100, but Processing May Increase or Reduce Protein Quality. British Journal of Nutrition 2020, 124 (1), 14-22. https://doi.org/10.1017/S0007114520000641.

(5) Bax, M.-L.; Aubry, L.; Ferreira, C.; Daudin, J.-D.; Gatellier, P.; Re, D.; Sante, ronique. Cooking Temperature Is a Key Determinant of in Vitro Meat Protein Digestion Rate: Investigation of Underlying Mechanisms. 2012. https://doi.org/10.1021/jf205280y.

(6) Shani-Levi, C.; Alvito, P.; Andrés, A.; Assunção, R.; Barberá, R.; Blanquet-Diot, S.; Bourlieu, C.; Brodkorb, A.; Cilla, A.; Deglaire, A.; Denis, S.; Dupont, D.; Heredia, A.; Karakaya, S.; Giosafatto, C. V. L.; Mariniello, L.; Martins, C.; Ménard, O.; El, S. N.; Vegarud, G. E.; Ulleberg, E.; Lesmes, U. Extending in Vitro Digestion Models to Specific Human Populations: Perspectives, Practical Tools and BioRelevant Information. Trends in Food Science and Technology. Elsevier 2017, pp 52-63. https://doi.org/10.1016/j.tifs.2016.10.017.

(7) Toldrá, F.; Reig, M.; Aristoy, M. C.; Mora, L. Generation of Bioactive 
Peptides during Food Processing. Food Chemistry 2018, 267, 395404. https://doi.org/10.1016/j.foodchem.2017.06.119.

(8) AOAC. Official Methods of Análisis. Association of Official Analytical Chemists. 15th Edition. 2000.

(9) Pematilleke, N.; Kaur, M.; Adhikari, B.; Torley, P. Influence of Meat Texture on Oral Processing and Bolus Formation. Journal of Food Engineering 2020, 283, 110038. https://doi.org/10.1016/j.jfoodeng.2020.110038.

(10) Hernández-Olivas, E.; Muñoz-Pina, S.; Andrés, A.; Heredia, A. Impact of Elderly Gastrointestinal Alterations on in Vitro Digestion of Salmon, Sardine, Sea Bass and Hake: Proteolysis, Lipolysis and Bioaccesibility of Calcium and Vitamins. Food Chemistry 2020, 326. https://doi.org/10.1016/j.foodchem.2020.127024.

(11) Minekus, M.; Alminger, M.; Alvito, P.; Ballance, S.; Bohn, T.; Bourlieu, C.; Carrière, F.; Boutrou, R.; Corredig, M.; Dupont, D.; Dufour, C.; Egger, L.; Golding, M.; Karakaya, S.; Kirkhus, B.; Le Feunteun, S.; Lesmes, U.; Maclerzanka, A.; MacKie, A.; Marze, S.; McClements, D. J.; Ménard, O.; Recio, I.; Santos, C. N.; Singh, R. P.; Vegarud, G. E.; Wickham, M. S. J.; Weitschies, W.; Brodkorb, A. A Standardised Static in Vitro Digestion Method Suitable for Food-an International Consensus. Food and Function 2014, 5 (6), 1113-1124. https://doi.org/10.1039/c3fo60702j.

(12) Jalabert-Malbos, M. L.; Mishellany-Dutour, A.; Woda, A.; Peyron, M. A. Particle Size Distribution in the Food Bolus after Mastication of Natural Foods. Food Quality and Preference 2007, 18 (5), 803-812. https://doi.org/10.1016/j.foodqual.2007.01.010.

(13) Lamothe, S.; Azimy, N.; Bazinet, L.; Couillard, C.; Britten, M. Interaction of Green Tea Polyphenols with Dairy Matrices in a Simulated Gastrointestinal Environment. 2014. https://doi.org/10.1039/c4fo00203b. 
(14) Akillioğlu, H. G.; Karakaya, S. Effects of Heat Treatment and in Vitro Digestion on the Angiotensin Converting Enzyme Inhibitory Activity of Some Legume Species. European Food Research and Technology 2009, 229 (6), 915-921. https://doi.org/10.1007/s00217-009-1133$\mathrm{x}$.

(15) Bohrer, B. M. Review: Nutrient Density and Nutritional Value of Meat Products and Non-Meat Foods High in Protein. Trends in Food Science and Technology. Elsevier Ltd 2017, pp 103-112. https://doi.org/10.1016/j.tifs.2017.04.016.

(16) Martini, S.; Conte, A.; Tagliazucchi, D. Comparative Peptidomic Profile and Bioactivities of Cooked Beef, Pork, Chicken and Turkey Meat after in Vitro Gastro-Intestinal Digestion. Journal of Proteomics 2019, 208, 103500. https://doi.org/10.1016/j.jprot.2019.103500.

(17) Wen, S.; Zhou, G.; Song, S.; Xu, X.; Voglmeir, J.; Liu, L.; Zhao, F.; Li, M.; $\mathrm{Li}$, L.; Yu, X.; Bai, Y.; Li, C. Discrimination of in Vitro and in Vivo Digestion Products of Meat Proteins from Pork, Beef, Chicken, and Fish. Proteomics 2015, 15 (21), 3688-3698. https://doi.org/10.1002/pmic.201500179.

(18) Dekkers, B. L.; Kolodziejczyk, E.; Acquistapace, S.; Engmann, J.; Wooster, T. J. Impact of Gastric PH Profiles on the Proteolytic Digestion of Mixed Blg-Xanthan Biopolymer Gels. Food and Function 2016, 7 (1), 58-68. https://doi.org/10.1039/c5fo01085c.

(19) Luo, Q.; Boom, R. M.; Janssen, A. E. M. Digestion of Protein and Protein Gels in Simulated Gastric Environment. LWT 2015, 63 (1), 161-168. https://doi.org/10.1016/j.lwt.2015.03.087.

(20) Yin, Y.; Zhou, L.; Pereira, J.; Zhang, J.; Zhang, W. Insights into Digestibility and Peptide Profiling of Beef Muscle Proteins with Different Cooking Methods. Journal of Agricultural and Food Chemistry 2020, acs.jafc.0c04054. https://doi.org/10.1021/acs.jafc.0c04054. 
(21) Xiong, Y. L. Muscle Proteins. In Proteins in Food Processing: Second Edition; Elsevier Inc., 2018; pp 127-148. https://doi.org/10.1016/B978-0-08-100722-8.00006-1.

(22) Sorapukdee, S.; Kongtasorn, C.; Benjakul, S.; Visessanguan, W. Influences of Muscle Composition and Structure of Pork from Different Breeds on Stability and Textural Properties of Cooked Meat Emulsion. Food Chemistry 2013, 138 (2-3), 1892-1901. https://doi.org/10.1016/j.foodchem.2012.10.121.

(23) Zou, X.; Zhou, G.; Yu, X.; Bai, Y.; Wang, C.; Xu, X.; Dai, C.; Li, C. In Vitro Protein Digestion of Pork Cuts Differ with Muscle Type. Food Research International 2018, 106, 344-353. https://doi.org/10.1016/j.foodres.2017.12.070.

(24) Reynaud, Y.; Buffière, C.; David, J.; Cohade, B.; Vauris, M.; Lopez, M.; Souchon, I.; Dupont, D.; Rémond, D. Temporal Changes in Postprandial Intragastric PH: Comparing Measurement Methods, Food Structure Effects, and Kinetic Modelling. Food Research International 2020, 128, 108784. https://doi.org/10.1016/j.foodres.2019.108784.

(25) Mennah-Govela, Y. A.; Cai, H.; Chu, J.; Kim, K.; Maborang, M. K.; Sun, W.; Bornhorst, G. M. Buffering Capacity of Commercially Available Foods Is Influenced by Composition and Initial Properties in the Context of Gastric Digestion. Food and Function 2020, 11 (3), 22552267. https://doi.org/10.1039/c9fo03033f.

(26) Tan, S. M.; Lee, S. M.; Dykes, G. A. Fat Contributes to the Buffering Capacity of Chicken Skin and Meat but Enhances the Vulnerability of Attached Salmonella Cells to Acetic Acid Treatment. Food Research International 2014, 66, 417-423. https://doi.org/10.1016/j.foodres.2014.10.007.

(27) Denis, S.; Sayd, T.; Georges, A.; Chambon, C.; Chalancon, S.; SantéLhoutellier, V.; Blanquet-Diot, S. Digestion of Cooked Meat Proteins 
Is Slightly Affected by Age as Assessed Using the Dynamic Gastrointestinal TIM Model and Mass Spectrometry. Food and Function 2016, 7 (6), 2682-2691. https://doi.org/10.1039/c6fo00120c.

(28) Liao, S. F.; Wang, T.; Regmi, N. Lysine Nutrition in Swine and the Related Monogastric Animals: Muscle Protein Biosynthesis and Beyond. SpringerPlus. SpringerOpen 2015, pp 1-12. https://doi.org/10.1186/s40064-015-0927-5.

(29) Fernstrom, J. D.; Fernstrom, M. H. Tyrosine, Phenylalanine, and Catecholamine Synthesis and Function in the Brain. In Journal of Nutrition; American Institute of Nutrition, 2007; Vol. 137, pp 1539S1547S. https://doi.org/10.1093/jn/137.6.1539s.

(30) Bao, W.; Li, Q.; Wu, Y.; Ouyang, J. Insights into the Crystallinity and in Vitro Digestibility of Chestnut Starch during Thermal Processing. Food Chemistry 2018, 269, 244-251. https://doi.org/10.1016/j.foodchem.2018.06.128.

(31) Xu, X.; Chen, X.; Chen, D.; Yu, B.; Yin, J.; Huang, Z. Effects of Dietary Apple Polyphenol Supplementation on Carcass Traits, Meat Quality, Muscle Amino Acid and Fatty Acid Composition in Finishing Pigs. Food and Function 2019, 10 (11), 7426-7434. https://doi.org/10.1039/c9fo01304k.

(32) Aderinola, T. A.; Fagbemi, T. N.; Enujiugha, V. N.; Alashi, A. M.; Aluko, R. E. Amino Acid Composition and Antioxidant Properties of Moringa Oleifera Seed Protein Isolate and Enzymatic Hydrolysates. Heliyon 2018, 4 (10), e00877. https://doi.org/10.1016/j.heliyon.2018.e00877.

(33) Sangsawad, P.; Roytrakul, S.; Yongsawatdigul, J. Angiotensin Converting Enzyme (ACE) Inhibitory Peptides Derived from the Simulated in Vitro Gastrointestinal Digestion of Cooked Chicken Breast. Journal of Functional Foods 2017, 29, 77-83. 
https://doi.org/10.1016/j.jff.2016.12.005.

(34) Mora, L.; Bolumar, T.; Heres, A.; Toldrá, F. Effect of Cooking and Simulated Gastrointestinal Digestion on the Activity of Generated Bioactive Peptides in Aged Beef Meat. Food and Function 2017, 8 (12), 4347-4355. https://doi.org/10.1039/c7fo01148b.

(35) Natesh, R.; Schwager, S. L. U.; Sturrock, E. D.; Acharya, K. R. Crystal Structure of the Human Angiotensin-Converting Enzyme-Lisinopril Complex. Nature 2003, 421 (6922), 551-554. https://doi.org/10.1038/nature01370.

(36) Foltz, M.; Van Buren, L.; Klaffke, W.; Duchateau, G. S. M. J. E. Modeling of the Relationship between Dipeptide Structure and Dipeptide Stability, Permeability, and ACE Inhibitory Activity. Journal of Food Science 2009, 74 (7), H243-H251. https://doi.org/10.1111/j.1750-3841.2009.01301.x.

(37) Serpen, A.; Gökmen, V.; Fogliano, V. Total Antioxidant Capacities of Raw and Cooked Meats. Meat Science 2012, 90 (1), 60-65. https://doi.org/10.1016/j.meatsci.2011.05.027.

(38) Kitts, D.; Weiler, K. Bioactive Proteins and Peptides from Food Sources. Applications of Bioprocesses Used in Isolation and Recovery. Current Pharmaceutical Design 2005, 9 (16), 1309-1323. https://doi.org/10.2174/1381612033454883.

(39) Wu, G. Functional Amino Acids in Growth, Reproduction, and Health. Advances in Nutrition 2010, 1 (1), 31-37. https://doi.org/10.3945/an.110.1008.

(40) Sarmadi, B. H.; Ismail, A. Antioxidative Peptides from Food Proteins: A Review. Peptides. Elsevier 2010, pp 1949-1956. https://doi.org/10.1016/j.peptides.2010.06.020. 
5.5 Chapter 5: Age-related gastrointestinal alterations of legumes and cereal grains digestibility.

Ever Hernández-Olivas, Sara Muñoz-Pina, Ana Andrés and Ana Heredia Food Bioscience 2021, 41, 101027. https://doi.org/10.1016/j.fbio.2021.101027. 


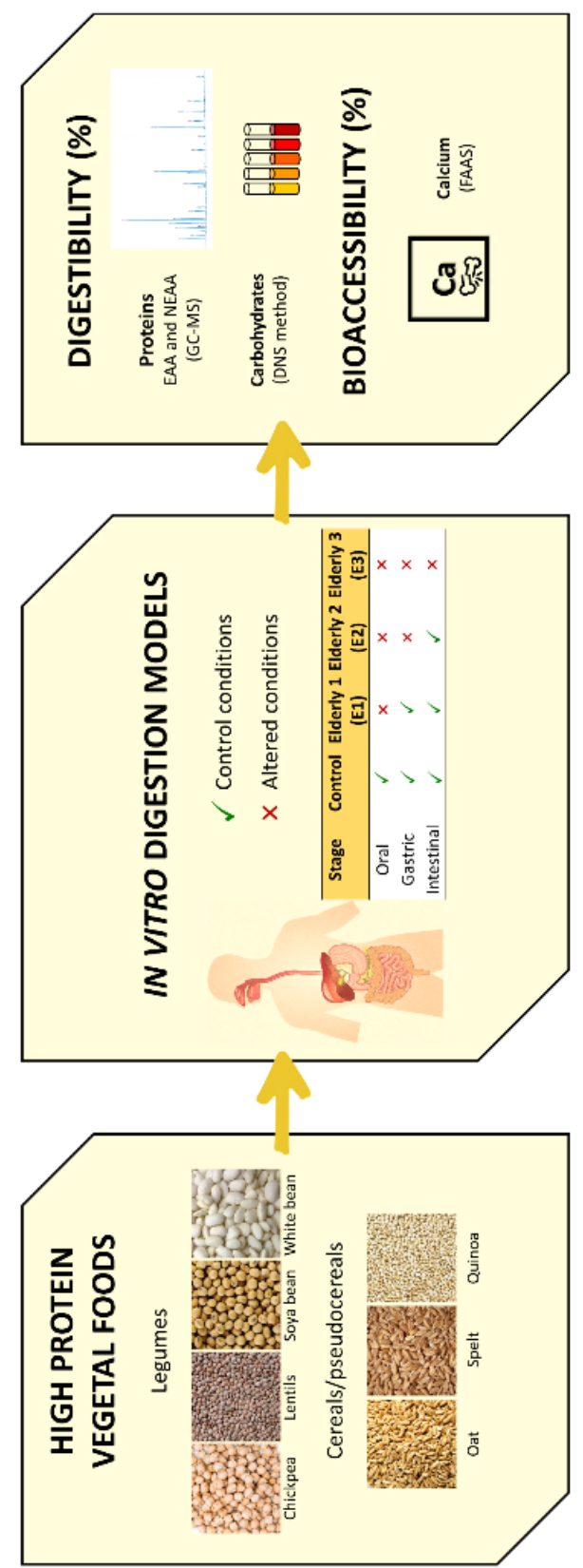




\section{Abstract}

Aging is accompanied by changes in gastrointestinal functions. The impact of the gastrointestinal (GI) conditions of the elderly on the extent of proteolysis and glycolysis as well as calcium bioaccessibility in some cooked legumes (chickpea, lentils, soya bean and white bean) and cereals/pseudocereals (oats, spelt and quinoa) were studied. Samples were digested in vitro using three GI models specifically focused on the elderly in which oral, gastric and intestinal conditions were altered (E1: altered oral conditions, E2: altered oral and gastric conditions and E3: altered oral, gastric and intestinal conditions). Samples were also subjected to a standardized GI digestion as a control (C). The extent of proteolysis was only significantly affected with suboptimal intestinal conditions $(p<0.05)$. Protein digestibility of cereal grains decreased to a greater extent than for legumes. The release of non-essential amino acids was more affected than that of essential ones, mainly in legumes such as soya bean, lentils and white bean. The extent of glycolysis was much higher in cereal grains than legumes regardless of $\mathrm{Gl}$ digestion conditions. Glycolysis declined with altered intestinal conditions (E3) compared to the $C$, in all legumes and spelt. Calcium bioaccessibility was much higher in cereal/pseudocereals than in legumes. However, calcium bioaccessibility seems to be highly limited in elderly people suffering from oral, gastric or intestinal alterations (up to 53\% reduction compared to $\mathrm{C}$ ). Such data might be helpful to develop dietary strategies based on protein-rich vegetal foods, including alternative crops such as oats, quinoa and spelt, specifically used to mitigate sarcopenia and osteoporosis in elderly people.

Key words: ageing; legumes; grains; digestibility; calcium bioaccessibility. 


\section{INTRODUCTION}

The world population has been predicted to exceed 9.7 billion by 2050 . In addition, people above age 65 are expected to considerably increase, exceeding the number of children by $2045^{1}$. The nutrition of the elderly is a global concern since health conditions and body composition change with age. Protein intake has an important role as its deficit is associated with muscle mass loss (sarcopenia) or physical weakness (asthenia) amongst other conditions. Moreover, calcium and vitamin D deficiencies have been associated with osteoporosis which increases the risk of fractures ${ }^{2,3}$. Meat, fish and dairy products, which are important sources of high biological value proteins, are often unaffordable for those with low incomes. Therefore, the Food and Agriculture Organization of the United Nations (FAO) has recommended an increase of legume consumption because of their high protein content, their affordability, and their contribution to food security and environmental sustainability ${ }^{4}$. Legumes are good sources of vegetable protein and minerals, especially iron, zinc, and calcium as well as relevant quantities of phenolic compounds ${ }^{5-7}$. Additionally, they also have complex carbohydrates and dietary fiber which makes their glycemic-index low ${ }^{8}$. Studies associate their consumption with a lower prevalence and incidence of illness (obesity, cardiovascular disease, type 2 diabetes, and some types of cancers) ${ }^{9,10}$. Thus, to supply the nutritional needs of the elderly, the World Health Organization (WHO) has recommended the intake of healthy legume-based dishes ${ }^{11}$. However, some minor grains such as quinoa, oats or spelt, have also gained interest due to their higher content of nutrients not found in relevant amounts in the major cereal crops such as wheat, rice or corn (maize). In addition, they contribute to the diversification of food crops which can help stabilize global food production ${ }^{12}$. Therefore, they should be considered as future alternative sources of protein for the elderly, and for the human population in general. Minor crops such as oats and spelt 
are also a good source of dietary fiber, vitamin B, and numerous dietary minerals. Additionally, oats contain legume-like protein and their quality is nearly equivalent to soy protein, hence the World Health Organization study has shown they are the closest vegetable proteins to meat, milk, and egg protein ${ }^{13}$. Quinoa, considered as a pseudo-cereal in the botanic classification, is characterized by its large amount of essential amino acids (EAA), especially Lys, which is close to the standards set by FAO for human nutrition ${ }^{14}$. Thus, FAO has recommended quinoa intake due to its wellbalanced proteic profile similar to that of milk ${ }^{15}$. Compared to most cereals, quinoa has higher amounts of vitamins and minerals such as calcium, iron and copper, as well as a lower carbohydrate content (than wheat, barley, corn and rice) ${ }^{16}$. However, these benefits can be limited in the elderly due to poor mastication, reduced digestive enzymes and bile salts secretion, suboptimal $\mathrm{pH}$ or longer transit time through the gastrointestinal (GI) tract, amongst others ${ }^{17}$. The structural matrix, chemical properties or the interactions among macro- and micronutrients can also modulate digestibility altering hydrolysis with similar digestive conditions. However, studies aiming to elucidate the contribution of food-inherent factors from other crops on digestibility and the different GI alterations in the elderly are limited.

Therefore, this study aimed to analyze the impact of GI alterations, frequently found in the elderly, on protein and carbohydrate digestibility and calcium bioaccessibility in 4 legumes (chickpea, lentils, white bean and soya bean) and three alternative grains (oats, spelt and quinoa) using a static in vitro digestion system.

\section{MATERIAL AND METHODS}

\section{Chemicals}


Pepsin from porcine gastric mucosa (3200-4500 U/mg, P6887), pancreatin (8 x USP, P7545) from porcine pancreas, p-toluene-sulfonyl-L-arginine methyl ester (TAME, T4626), bovine bile (dried, unfractionated, B3883), analytical grade salts (potassium chloride, potassium dihydrogen phosphate, sodium bicarbonate, sodium chloride, magnesium chloride, ammonium carbonate, calcium chloride, potassium sulfate and potassium sodium tartrate tetrahydrate), boric acid, hydrochloric acid (37\%), sulfuric acid (95-97\%), sodium hydroxide, DNS (3-5' dinitrosalicylic acid) reagent, D+-glucose ( $\geq 99.5 \%)$, ethanol (96\%) and invertase from baker's yeast (Grade VII, $\geq 300$ units/mg solid, 14504) were obtained from Sigma-Aldrich Co. (St. Louis, MO, USA). Nitric acid (70\%) and lanthanum (III) chloride heptahydrate (analytical grade) were purchased from Honeywell Fluka (Morris Plains, NJ, USA); petroleum ether (VWR Chemicals, VWR International Pty. Ltd., Murarrie, Queensland, Australia), amyloglucosidase (Aspergillus niger) (EAMGDF, Megazyme, Bray, Ireland) and EZ-Faast amino acid kit (Phenomenex, Torrance, CA, USA) were also used.

Legumes (chickpea (Cicer arietinum, Hacendado ${ }^{\circledR}$, Valencia, Spain), pardina lentils (Lens culinaris var. Variabilis, Hacendado ${ }^{\circledR}$ ), white bean (Phaseolus vulgaris, Hacendado ${ }^{\circledR}$ ) and soya bean (Glycine max, Biográ ${ }^{\circledR}$, Barcelona, Spain)) and cereal grains (whole oats (Avena sativa, Biográ ${ }^{\circledR}$ ), whole spelt (Triticum spelta, Biográ ${ }^{\circledR}$ ) and quinoa (Chenopodium quinoa, Hacendado ${ }^{\circledR}$ )) were purchased previously dried for retail sales at local stores in Valencia (Spain).

\section{Sample preparation}

Legumes and cereal grains were soaked (excepting lentils and quinoa) and boiled before in vitro digestion studies. Soaking was overnight with deionized water (Barnstead Mega-Pure deionizer, Thermo-Fisher Scientific, Waltham, MA, USA) at a ratio of $1: 3(w: w)$ grain:water at $20 \pm 1{ }^{\circ} \mathrm{C}$. 
Subsequently, soaked grains were boiled at $95 \pm 5{ }^{\circ} \mathrm{C}$ with deionized water with a ratio of $1: 3(\mathrm{w}: \mathrm{w})$ grain:water for $60,45,30,60$ and 25 min for soya bean, chickpea, white bean, whole spelt and whole oats, respectively. Pardina lentils and quinoa were directly boiled at the same grain:water ratio for 20 and $10 \mathrm{~min}$, respectively. Cooking time was determined and adjusted for each variety in preliminary analyses considering label recommendation, i.e., until legumes could be crushed with fingers and reached a moisture content of $60 \pm 6 \%$ (on a wet basis). All cooked samples were drained in a kitchen sieve for $2 \mathrm{~min}$ and kept cool at $20 \pm 2{ }^{\circ} \mathrm{C}$ until they reached this temperature. Cooked samples were then immediately used for composition analysis and in vitro digestion.

\section{Compositional analysis}

After cooking and cooling, moisture, ash, fat, fiber and crude protein (using a Kjeldahl factor of 5.70) contents were characterized in the samples according to the AOAC official methods 934.01, 942.05, 920.39, 962.09 and $960.52^{18}$, respectively. Initial sugars and total starch content were also determined quantifying glucose using the DNS colorimetric method according to Armellini et al. (2019) ${ }^{19}$. Before the measurement of total starch, samples were freeze-dried, mill, gelatinized and digested (using amyloglucosidase). In addition, ash was dissolved in a $20 \%$ nitric acid solution and La (III) was added to $0.1 \%(\mathrm{w} / \mathrm{v})$ to determine calcium content using an iCE 3000 Series flame atomic absorption spectrometer (Thermo Scientific, Waltham, MA, USA). Air:acetylene (11.5:1.5 $\mathrm{L} \mathrm{min}^{-1}$ ) were used in the flame and samples were measured at $422.7 \mathrm{~nm} . \mathrm{CaCO}_{3}$ was used to obtain a calibration curve (from 0 to $10 \mathrm{mg} / \mathrm{L}$ of $\mathrm{Ca}$ ) ${ }^{20}$.

\section{Static in vitro simulation of GI digestion}


The control model (C) corresponded to the standard GI conditions of a healthy adult as often defined in these types of experiments ${ }^{21}$. Particularly controversial is the gastric $\mathrm{pH}$. Reports show $\mathrm{pH}$ values between 1.5 and 4.0 (Biehler et al., 2011; Oomen et al., 2003; Reboul et al., 2006). The elderly models simulating the accumulative alterations that appear as a consequence of ageing (Elderly 1 (oral stage altered (E1), Elderly 2 (oral and gastric stages altered (E2)) and Elderly 3 (oral, gastric and intestinal stages altered (E3)) (Table 5.5.1). Specific digestive conditions in the elderly were established according to Shani-Levi et al. (2017) ${ }^{22}$, except for the transit time of the gastric and intestinal stages ${ }^{23}$. Chewing (number of mastication cycles) was standardized ${ }^{24}$ and done in vivo using a healthy volunteer (male student, 30 years old) with good dentition until reaching a bolus consistency similar to a tomato or mustard paste ${ }^{21}$. For the elderly, the number of chewing cycles were reduced to $50 \%$ by the same volunteer to mimic one of the most critical oral changes with the elderly, i.e., edentulism, generating a bolus with a larger particle size and more difficult to swallow ${ }^{25,26}$. Thus, 20 and 10 chewing cycles for a healthy adult and the elderly, respectively, were done for all the cooked foods (except for soya bean). Harder food would generally require more chewing cycles (Chen, 2009), i.e., soya bean, where 30 and 15 chewing cycles were needed.

All materials were digested at least three times using each GI conditions (C, E1, E2 and E3). Table 5.5.1 shows the specific conditions of each digestion model. Gastric (SGS) and intestinal (SIS) digestion fluids were prepared fresh daily from stock solutions and the digestive enzymatic activity of the enzymes were tested before each experiment according to Minekus et al. $(2014)^{21}$. Briefly, the trypsin activity of pancreatin was measured using a continuous spectrophotometric rate determination (using Helios Zeta UVVIS Spectrophotometer, Thermo Fisher Scientific) using p-toluene-sulfonyl$\mathrm{L}$-arginine methyl ester (TAME) as the substrate at different concentrations 
Table 5.5.1. Specific GI conditions set for the 4 in vitro digestion models of this study.

\begin{tabular}{|c|c|c|c|c|}
\hline \multirow{2}{*}{ Digestive stage } & \multicolumn{4}{|c|}{ In vitro digestion model } \\
\hline & Control (C) & Elderly 1 (E1) & Elderly 2 (E2) & Elderly 3 (E3) \\
\hline Oral stage & $\begin{array}{l}5 \mathrm{~g} \text { of food sample }+ \\
\text { human salivary fluid } \\
\text { Chewing until a } \\
\text { consistency like a } \\
\text { tomato or mustard paste } \\
\text { is obtained ( } 20 \text { and } 30 \\
\text { cycles for other and soya } \\
\text { bean, respectively) }\end{array}$ & $\begin{array}{l}5 \mathrm{~g} \text { of food sample }+ \\
\text { human salivary fluid } \\
50 \% \text { of the Control } \\
\text { chewing cycles } \\
55 \mathrm{rpm} \text { at } 37^{\circ} \mathrm{C}\end{array}$ & $\begin{array}{l}5 \mathrm{~g} \text { of food sample + human } \\
\text { salivary fluid } \\
50 \% \text { of the Control chewing } \\
\text { cycles } \\
55 \mathrm{rpm} \text { at } 37^{\circ} \mathrm{C}\end{array}$ & $\begin{array}{l}5 \mathrm{~g} \text { of food sample }+ \text { human } \\
\text { salivary fluid } \\
50 \% \text { of the Control chewing } \\
\text { cycles } \\
55 \text { rpm at } 37^{\circ} \mathrm{C}\end{array}$ \\
\hline Gastric stage & $\begin{array}{l}\text { Oral bolus }+10 \mathrm{~mL} \text { SGF } \\
\mathrm{pH} 3 \\
\text { Pepsin }(2000 \mathrm{U} / \mathrm{mL}) \\
2 \mathrm{~h}\end{array}$ & $\begin{array}{l}\text { Oral bolus }+10 \mathrm{~mL} \mathrm{SGF} \\
\mathrm{pH} 3 \\
\text { Pepsin }(2000 \mathrm{U} / \mathrm{mL}) \\
2 \mathrm{~h} \\
55 \mathrm{rpm} \text { at } 37^{\circ} \mathrm{C}\end{array}$ & $\begin{array}{l}\text { Oral bolus }+10 \mathrm{~mL} \mathrm{SGF} \\
\mathrm{pH} 6 \\
\text { Pepsin }(1500 \mathrm{U} / \mathrm{mL}) \\
2 \mathrm{~h} \\
55 \mathrm{rpm} \text { at } 37^{\circ} \mathrm{C}\end{array}$ & $\begin{array}{l}\text { Oral bolus }+10 \mathrm{~mL} \text { SGF } \\
\mathrm{pH} 6 \\
\text { Pepsin }(1500 \mathrm{U} / \mathrm{mL}) \\
2 \mathrm{~h} \\
55 \mathrm{rpm} \text { at } 37^{\circ} \mathrm{C}\end{array}$ \\
\hline Intestinal stage & $\begin{array}{l}\text { Gastric chime }+20 \mathrm{~mL} \text { SIF } \\
\mathrm{pH} 7 \\
\text { Bile }(10 \mathrm{mM}) \\
+ \text { Pancreatin } \\
(100 \mathrm{U} / \mathrm{mL}) \\
2 \mathrm{~h}\end{array}$ & $\begin{array}{l}\text { Gastric chime }+20 \mathrm{~mL} \text { SIF } \\
\mathrm{pH} 7 \\
\text { Bile }(10 \mathrm{mM}) \\
+ \text { Pancreatin } \\
(100 \mathrm{U} / \mathrm{mL}) \\
2 \mathrm{~h} \\
55 \mathrm{rpm} \text { at } 37^{\circ} \mathrm{C}\end{array}$ & $\begin{array}{l}\text { Gastric chime }+20 \mathrm{~mL} \text { SIF } \\
\mathrm{pH} 7 \\
\text { Bile }(10 \mathrm{mM}) \\
+ \text { Pancreatin } \\
(100 \mathrm{U} / \mathrm{mL}) \\
2 \mathrm{~h} \\
55 \mathrm{rpm} \text { at } 37^{\circ} \mathrm{C}\end{array}$ & $\begin{array}{l}\text { Gastric chime }+20 \mathrm{~mL} \text { SIF } \\
\mathrm{pH} 7 \\
\text { Bile }(5 \mathrm{mM}) \\
+ \text { Pancreatin } \\
(50 \mathrm{U} / \mathrm{mL}) \\
4 \mathrm{~h} \\
55 \mathrm{rpm} \text { at } 37^{\circ} \mathrm{C}\end{array}$ \\
\hline
\end{tabular}


to obtain the rate at $247 \mathrm{~nm}$. One trypsin unit hydrolyses $1 \mu$ mole of $\mathrm{TAME} / \mathrm{min}$ at $25^{\circ} \mathrm{C}, \mathrm{pH} 8.1$. Likewise, the enzymatic activity of pepsin was measured at $280 \mathrm{~nm}$ using the spectrophotometric stop rate determination using different concentrations of hemoglobin as substrate. One pepsin unit will produce a $\Delta \mathrm{A}_{280}$ of $0.001 / \mathrm{min}$ at $\mathrm{pH} 2.0$ and $37^{\circ} \mathrm{C}$, measured as TCAsoluble products.

After digestion, the $\mathrm{pH}$ of digests was adjusted to 5 and kept in an ice bath for $10 \mathrm{~min}$ to inhibit the enzymatic reactions before fraction separation and analytical determinations. The separation of the liquid fraction from the undigested remaining solids was done using a centrifuge at $4000 \times \mathrm{g}$ (5810R, Eppendorf, Hamburg, Germany) for $5 \mathrm{~min}$ at $10{ }^{\circ} \mathrm{C}$ to obtain the supernatant.

\section{Analytical determinations}

\section{Free amino acids (FAA)}

Essential (EAA) and non-essential (NEAA) amino acids from protein digestion were determined using the protocol by Peinado et al. (2016) ${ }^{27}$ with some modifications. Briefly, the amine and carboxyl groups of the FAA contained in $100 \mu \mathrm{L}$ of the bioaccessible fraction were derivatized at room temperature in aqueous solution using the EZ-Faast amino acid kit. Derivatized samples were measured using a GC-MS (Injector 7683B series, Network GC System 6890N series, Inert Mass Selective Detector 5975 series, MSD ChemStation software) (Agilent Technologies, Palo Alto, CA, USA) using norvaline as an internal standard. A calibration of the peak area was prepared for each amino acid using the amino acids standard solution included in the kit. The extent of proteolysis was estimated considering the sum of the FAA in the bioaccessible fraction with respect to the amount of crude protein in undigested cooked food (equation 5.15). 
Extent of proteolysis (\%)

$$
=\frac{(\mathrm{g} F A A \text { in bioaccessible fraction })}{(\mathrm{g} \text { crude protein in undigested cooked food })} \times 100
$$

\section{Digestible starch}

Reducing sugars released during digestion (monosaccharides) were determined in the bioaccessible fraction with a colorimetric method using dinitrosalicylic acid (DNS) after an invertase and amyloglucosidase secondary digestion ${ }^{19}$. An aliquot of $1 \mathrm{~mL}$ of the bioaccessible fraction was mixed with $4 \mathrm{~mL}$ of absolute ethanol to prepare an extract. The ethanolic extract $(50 \mu \mathrm{L})$ were added to $250 \mu \mathrm{L}$ of the enzymatic solution (1\% amyloglucosidase $+1 \%$ invertase in acetate buffer, $\mathrm{pH}$ 5.2) and incubated at $37^{\circ} \mathrm{C}$ for $10 \mathrm{~min}$. The DNS mixture (750 $\mu \mathrm{L}$ containing a 1:1:5 mixture of 0.5 $\mathrm{mg} / \mathrm{mL}$ glucose:4 M NaOH:DNS reagent (10 g/L of 3,5-dinitrosalicylic acid, containing $300 \mathrm{~g}$ potassium sodium tartrate and $16 \mathrm{~g} \mathrm{NaOH}$ )) were added and heated for $15 \mathrm{~min}$ at $100^{\circ} \mathrm{C}$. Then, $4 \mathrm{~mL}$ of cold deionized water were added and absorbances measured at $530 \mathrm{~nm}$ (using a Helios Zeta UV-VIS Spectrophotometer, Thermo Fisher Scientific). Glucose was used to obtain a calibration curve (from 0 to $10 \mathrm{mg} / \mathrm{L}$ ). The extent of glycolysis was calculated using equation 5.16 :

$$
\begin{aligned}
& \text { Extent of glycolysis }(\%) \\
& \qquad=\frac{(g \text { free glucose Eq. in bioaccessible fraction })}{(g \text { starch }(\text { glucose E } q \text {. }) \text { in undigested food })} \times 100
\end{aligned}
$$

\section{Calcium bioaccessibility}

An aliquot of $4 \mathrm{~mL}$ of the bioaccessible fraction was used for free calcium determination using flame atomic absorption spectroscopy (FAAS) using the 
same protocol used to determine the total amount of calcium in undigested samples. The bioaccessibility of calcium was estimated using equation 5.17:

Calcium bioaccessibility (\%)

$$
=\frac{\left(m g C a^{2+} \text { free in bioaccessible fraction }\right)}{\left(m g C a^{2+} \text { total in undigested food }\right)} \times 100
$$

\section{Statistical analysis}

Results were evaluated using an analysis of variance (multivariate ANOVA). In addition, multiple range tests were obtained using the LSD (least significant difference) of the Fisher test to identify homogeneous groups between models and foods. For these analyses, Statgraphics Centurion XVII software (Statgraphics Technologies Inc, The Plains, VA, USA) was used with a confidence level of $95 \%(p<0.05)$. Principal component analysis (PCA) was also used to determine the relationship among the experimental data (total, EAA and NEAA extents of proteolysis, the extent of glycolysis and calcium bioaccessibility).

\section{RESULTS AND DISCUSSION}

\section{Nutritional composition of legumes and cereal/pseudocereal grains}

Results from the compositional analysis in terms of the crude protein, total fat, ash, fiber, sugars and starch contents (Table 5.5.2) were comparable to those previously reported ${ }^{28-30}$. As expected, legumes showed higher protein content than grains, soya bean being the highest, and oats the lowest. In addition to the nutritional value, soya bean consumption has gained considerable attention given its beneficial effects on cardiovascular health by improving the lipid profile, glycaemia and insulin homeostasis, blood pressure and aiding weight control ${ }^{31}$. Grains ranged from $1 \%$ (spelt 
and white bean) to $10 \%$ (soya bean) of lipids on a dry basis. Moreover, fiber content was higher in legumes than in alternative crops. On the other hand, alternative crops showed greater starch content than legumes. Chickpea and oats were higher in calcium than other legume and grains while lentils and spelt had the lowest content of this mineral. These results were lower than those previously reported ${ }^{30,32-34}$ for the raw counterparts. Apparently, calcium lixiviation has been reported during soaking and/or cooking in some vegetal materials ${ }^{35}$. 
Table 5.5.2. Total contents of water, crude protein, fat, ash, reducing sugars, fiber, starch and calcium in cooked legumes (chickpea, lentils, soya bean and white bean) and grains (whole oats, whole spelt and quinoa).

\begin{tabular}{|c|c|c|c|c|c|c|c|}
\hline $\begin{array}{l}\text { Nutrient content } / 100 \mathrm{~g} \\
\text { dry basis }\end{array}$ & Chickpea & Lentils & Soya bean & White bean & Oats & Spelt & Quinoa \\
\hline Moisture (g) & $157 \pm 0.5^{d}$ & $123 \pm 0.2^{\mathrm{a}}$ & $175 \pm 1^{e}$ & $183 \pm 2^{f}$ & $136 \pm 3^{b}$ & $145 \pm 1^{c}$ & $259 \pm 4 \mathrm{~g}$ \\
\hline Crude protein (g) & $17.8 \pm 0.3^{e}$ & $17.1 \pm 0.2^{\mathrm{d}}$ & $41 \pm 1^{f}$ & $18.2 \pm 0.5^{e}$ & $11.3 \pm 0.2^{\mathrm{a}}$ & $14.1 \pm 0.1^{c}$ & $12.4 \pm 0.1^{b}$ \\
\hline Fat (g) & $5.7 \pm 0.1^{\mathrm{e}}$ & $1.7 \pm 0.5^{\mathrm{ab}}$ & $10 \pm 1^{f}$ & $1.1 \pm 0.4^{\mathrm{a}}$ & $2 \pm 0.2^{b c}$ & $0.8 \pm 0.1^{a}$ & $2.8 \pm 0.4^{d}$ \\
\hline Ash (g) & $2.2 \pm 0.2^{c}$ & $1.91 \pm 0.05^{b}$ & $2.9 \pm 0.2^{\mathrm{e}}$ & $3.17 \pm 0.05^{f}$ & $1.62 \pm 0.04^{a}$ & $2.1 \pm 0.1^{c}$ & $2.61 \pm 0.04^{d}$ \\
\hline Reducing sugars (g) & $0.09 \pm 0.02^{\mathrm{a}}$ & $0.16 \pm 0.01^{b}$ & $0.28 \pm 0.02^{c}$ & $0.11 \pm 0.002^{\mathrm{a}}$ & $0.30 \pm 0.01^{c}$ & $0.42 \pm 0.04^{d}$ & $0.46 \pm 0.05^{d}$ \\
\hline Fiber (g) & $20 \pm 2^{d}$ & $18 \pm 2^{d}$ & $17 \pm 1^{d}$ & $29 \pm 3^{e}$ & $4.0 \pm 0.4^{a}$ & $10 \pm 1^{c}$ & $7 \pm 1^{b}$ \\
\hline Starch (g) & $55 \pm 1^{c}$ & $62 \pm 1^{d}$ & $30 \pm 3^{a}$ & $48 \pm 3^{b}$ & $81 \pm 3^{\mathrm{fg}}$ & $74 \pm 1^{\mathrm{e}}$ & $75 \pm 4^{\mathrm{ef}}$ \\
\hline Calcium (mg) & $130 \pm 20^{e}$ & $13 \pm 1^{a}$ & $88 \pm 6^{d}$ & $85 \pm 4^{d}$ & $120 \pm 10^{e}$ & $30 \pm 3^{b}$ & $48 \pm 5^{c}$ \\
\hline
\end{tabular}

Data shown are mean values from triplicates and the standard deviation. abc Different lowercase letters indicate significant differences between foods, with a significance level of $95 \%(p<0.05)$. 


\section{Protein digestibility of legumes and grains simulating the elderly GI conditions}

The biological value of dietary proteins is given by the amino acid profile and its $\mathrm{Gl}$ digestion. Within the amino acids resulting from the protein enzymatic hydrolysis, the EAA have an important role in muscle protein synthesis ${ }^{36}$. Specifically, sarcopenia, the loss of muscle mass as a result of aging, causes functional decline and loss of independence in older adults ${ }^{37}$. Figure 5.5.1 shows the extent of proteolysis of the EAA and NEAA fractions found in legumes and grains digested with standard (C) and the elderly (E1, E2 and E3) GI conditions. The extent of proteolysis with standardized GI conditions (C) ranged from 56 to $100 \%$, depending on the food matrix. FAA digestibility extents in vegetal foods were similar to those achieved in digested highprotein foods such as meat or egg (60-90 and 40-80\%, respectively) ${ }^{23,38}$. However, protein in grains was slightly better digested than legumes. Similar results were reported in the literature for proteolysis with values ranging between $80-95 \%$ for oats, spelt and quinoa ${ }^{39-41}, 70-80 \%$ for legumes ${ }^{42}$, and $60 \%$ for soya bean ${ }^{43}$. The extent of proteolysis achieved by the samples, could be even higher than reported because of the extent of proteolysis calculation has been just based on FAA without taking into account the possible short-chain peptides which are also bioabsorbable. Among the legumes, higher proteolysis was obtained with chickpea and white bean compared to lentil and soya bean. The low protein hydrolysis obtained with soya bean could be due, apart from the presence of antinutritional factors, to the low porosity of the matrix. Even if a thermal process was used, remaining intact cells could occur and decrease considerably the cell wall permeability to proteolytic enzymes ${ }^{43}$. Soya bean has been associated with low digestibility due that possess a complex matrix mostly composed of protein bodies immersed in a lipid matrix of individual 
bodies and its cell wall is composed of pectins, being less degradable upon cooking ${ }^{44}$.
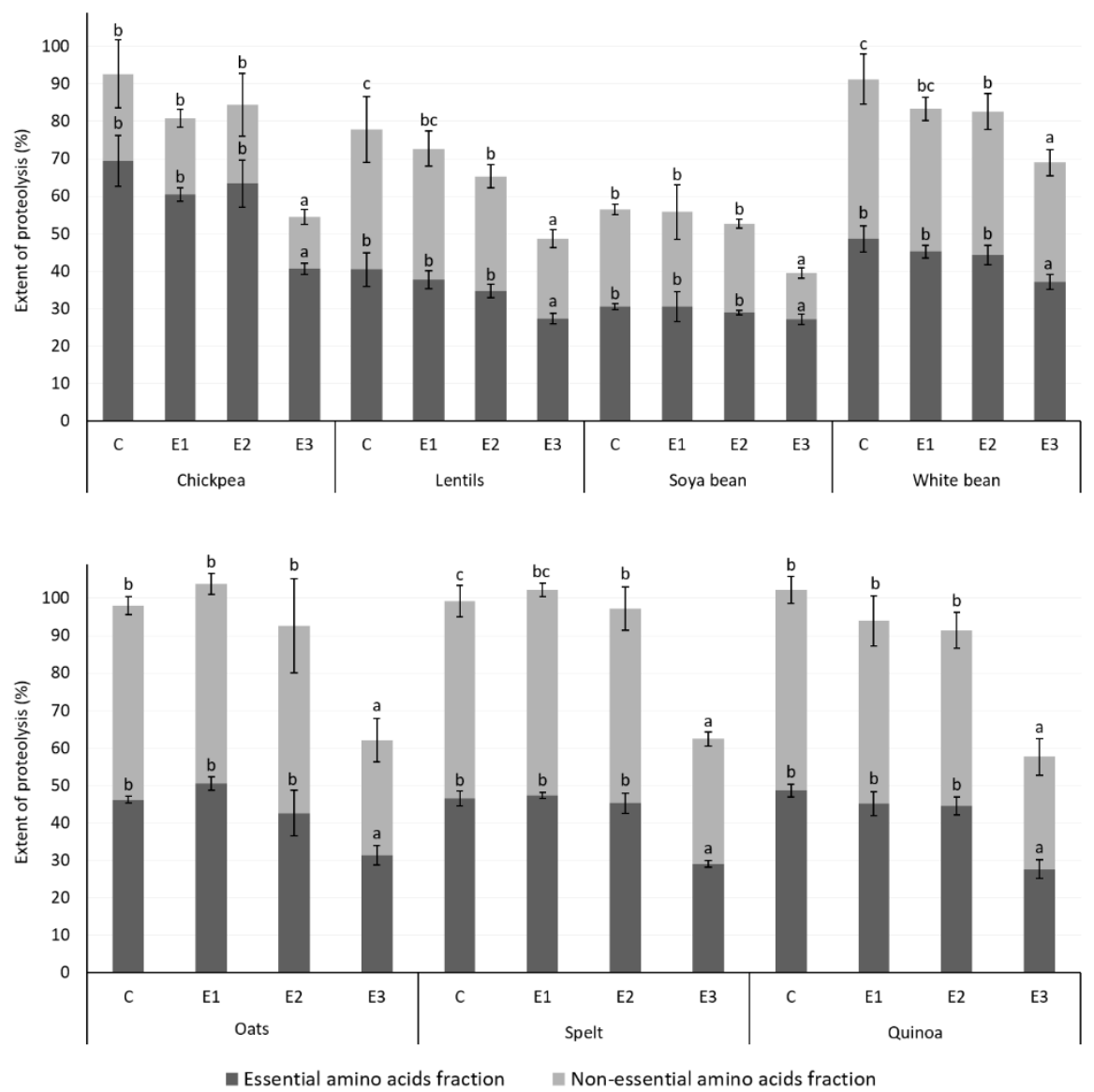

Figure 5.5.1. Extent of proteolysis (\%) of the EAA and NEAA fractions of A: Legumes (chickpea, lentils, soya bean and white bean) and B: Grains (oats, spelt and quinoa) obtained with different in vitro digestion models (C, E1, E2 and E3). ${ }^{a b c}$ Different lowercase letters indicate significant differences of EAA 
and the total extent of proteolysis between digestion models in each legume/grain $(p<0.05)$.

Only the intestinal alteration mimicked in the E3 model had a significant impact on protein hydrolysis. A significant decrease in proteolysis was observed in these $\mathrm{Gl}$ conditions compared to values obtained in $\mathrm{C}$. Thus, the extent of proteolysis achieved with E3 conditions ranged from 69 to $40 \%$ for white and soya beans, respectively. The decrease depended on the food type, being grain protein ( $\sim 40 \%$ of hydrolysis reduction) the most affected with these alterations than legumes. Reasonably, a decrease in the pancreatic enzyme and bile concentrations lead to maldigestion and malabsorption causing nutritional deficiencies ${ }^{2}$. Therefore, protein digestion would only be compromised in people suffering from pancreatic and/or biliar insufficiency.

EAA fraction increased from 30 to $69 \%$ in soya beans and from 27 to $41 \%$ in chickpeas in $\mathrm{C}$ conditions. Moreover, NEAA fraction ranged between 23 and $53 \%$ (soya bean being the lowest and chickpea the highest) in C conditions and fell from 13 to $30 \%$ (being chickpea/soya bean the lowest, and white bean and grains the highest values) in E3. In like manner, differences in the extent of proteolysis were only observed in suboptimal intestinal conditions (E3) compared to non-altered intestinal conditions (E2). Regarding the EAA:NEAA ratio (Figure 5.5.1), a 1:1 ratio was observed for all samples excepting chickpea (3:1 EAA:NEAA ratio) in C conditions. Chickpea protein has been reported as a good source of EAA such as isoleucine, lysine, tryptophan and aromatic amino acids ${ }^{45}$. EAA:NEAA ratio increased to $3: 1$ in soya bean (being 70 and $30 \%$ of the extent of proteolysis, respectively for EAA and NEAA) subjected to in vitro digestion using altered conditions (E3). Thus, the elderly $\mathrm{Gl}$ alterations seem to limit to a greater extent the release of NEAA than EAA in this legume. 
Tables 5.5.3 and 5.5.4 gather the EAA and NEAA profiles after GI in vitro simulation. These results were consistent with those reported by other authors $30,32,39,46$. Lys, Leu, Trp and Phe were present as the major amino acids in all cooked grains, whereas Met was determined to be a deficient amino acid. On the other hand, all grains showed low concentrations of Pro while GIn was not found. Pro and Gln are the amino acids present in prolamin and its presence can cause health issues such as celiac disease ${ }^{47}$.

In some foods, higher surface area in small particles allows higher enzyme access ${ }^{48}$. However, there were no differences in the results using altered oral stage (E1) compared to standard oral conditions (C) since products from protein hydrolysis were only quantified at the end of the intestinal stage, and therefore, the gastric and intestinal factors $\mathrm{pH}$, enzymes, surface active materials and other biological components) could mask the effect of differences in particle size. In the same way, the gastric stage did not show differences when E1 was compared to E2, showing that the activity of pancreatic proteases might compensate for the suboptimal conditions in the gastric stage (E2). Therefore, EAA such as Leu, lle and Val, also known as branched-chain amino acids (BCAA), are EAA that act as important substrates and important regulators in protein synthesis with heavier anabolic effects not just in healthy subjects, but also in the elderly ${ }^{49}$.

\section{Extent of glycolysis of legumes and grains using the GI elderly conditions}

Legume and grain starch digestibility was evaluated quantifying the amount of glucose released at the end of standardized (C) and the elderly (E1, E2 and E3) in vitro digestion. Figure 5.5.2 shows significant differences among legumes and grains in terms of starch hydrolysis, or the extent of glycolysis (\%) regardless of the GI digestion conditions. Thus, the extent of glycolysis varied from $22-35 \%$ for legumes and from 65 to 90\% (average values) for grains when $\mathrm{C}$ conditions were simulated. Other studies ${ }^{28,50-55}$ report a high 
Table 5.5.3. EAA profile (mg FAA/g protein) of chickpea, lentils, soya bean, white bean, oats, spelt and quinoa after in vitro digestion using different elderly digestion models.

\begin{tabular}{|c|c|c|c|c|c|c|c|c|c|c|}
\hline \multirow{2}{*}{ Vegetal food } & \multirow{2}{*}{ GI conditions } & \multicolumn{9}{|c|}{ EAA (mg free amino acid/ g protein) } \\
\hline & & Histidine & Isoleucine & Leucine & Lysine & Methionine & Phenylalanine & Threonine & Tryptophan & Valine \\
\hline \multirow{4}{*}{ Chickpea } & $\mathbf{C}$ & $48 \pm 7^{b}$ & $40 \pm 4^{b}$ & $90 \pm 10^{c}$ & $140 \pm 20^{b}$ & $19 \pm 2^{c}$ & $67 \pm 5^{c}$ & $30 \pm 3^{c}$ & $53 \pm 5^{c}$ & $51 \pm 5^{b}$ \\
\hline & E1 & $46 \pm 2^{b}$ & $35 \pm 1^{\mathrm{b}}$ & $76 \pm 1^{b}$ & $130 \pm 10^{\mathrm{b}}$ & $16.3 \pm 0.3^{b}$ & $55 \pm 2^{\mathrm{ab}}$ & $26 \pm 1^{b}$ & $44 \pm 2^{b}$ & $44 \pm 2^{b}$ \\
\hline & E2 & $48 \pm 4^{b}$ & $37 \pm 4^{b}$ & $80 \pm 10^{b}$ & $130 \pm 20^{b}$ & $17 \pm 1^{\mathrm{bc}}$ & $58 \pm 7^{b}$ & $27 \pm 2^{b c}$ & $46 \pm 3^{b}$ & $46 \pm 5^{b}$ \\
\hline & E3 & $36.0 \pm 0.4^{\mathrm{a}}$ & $26.9 \pm 0.1^{\mathrm{a}}$ & $59 \pm 1^{\mathrm{a}}$ & $70 \pm 10^{\mathrm{a}}$ & $12.8 \pm 0.3^{a}$ & $50 \pm 1^{\mathrm{a}}$ & $16.6 \pm 0.3^{a}$ & $35.0 \pm 0.4^{a}$ & $33.4 \pm 0.4^{a}$ \\
\hline \multirow{4}{*}{ Lentils } & $\mathrm{C}$ & $40 \pm 3^{b}$ & $36 \pm 4^{b}$ & $80 \pm 10^{b}$ & $120 \pm 20^{b}$ & $13 \pm 1^{b}$ & $54 \pm 7^{b}$ & $23 \pm 2^{b}$ & $39 \pm 3^{b}$ & $42 \pm 5^{b}$ \\
\hline & E1 & $40 \pm 1^{b}$ & $33 \pm 2^{b}$ & $70 \pm 10^{\mathrm{ab}}$ & $110 \pm 10^{\mathrm{b}}$ & $12 \pm 1^{b}$ & $48 \pm 3^{\mathrm{ab}}$ & $23 \pm 1^{b}$ & $37 \pm 2^{b}$ & $39 \pm 3^{b}$ \\
\hline & E2 & $41 \pm 2^{b}$ & $34 \pm 1^{b}$ & $73 \pm 3^{b}$ & $100 \pm 10^{\mathrm{ab}}$ & $12.1 \pm 0.5^{b}$ & $49 \pm 2^{\mathrm{ab}}$ & $23 \pm 1^{b}$ & $35 \pm 1^{b}$ & $40 \pm 2^{b}$ \\
\hline & E3 & $32 \pm 0.4^{a}$ & $28 \pm 1^{\mathrm{a}}$ & $61 \pm 3^{a}$ & $80 \pm 10^{a}$ & $9.2 \pm 0.3^{a}$ & $44 \pm 1^{\mathrm{a}}$ & $15 \pm 1^{\mathrm{a}}$ & $30 \pm 1^{a}$ & $33 \pm 2^{a}$ \\
\hline \multirow{4}{*}{ Soya bean } & C & $32 \pm 1^{b}$ & $26.3 \pm 0.3^{a}$ & $62 \pm 1^{\mathrm{a}}$ & $80 \pm 10^{b}$ & $12.2 \pm 0.4^{c}$ & $41 \pm 1^{\mathrm{a}}$ & $18 \pm 1^{b}$ & $34 \pm 1^{\mathrm{ab}}$ & $31 \pm 1^{\mathrm{a}}$ \\
\hline & E1 & $32 \pm 4^{b}$ & $25 \pm 4^{\mathrm{a}}$ & $60 \pm 10^{\mathrm{a}}$ & $90 \pm 10^{b}$ & $12 \pm 1^{b c}$ & $38 \pm 7^{\mathrm{a}}$ & $18 \pm 2^{b}$ & $35 \pm 5^{b}$ & $30 \pm 5^{a}$ \\
\hline & E2 & $31 \pm 1^{\mathrm{ab}}$ & $24 \pm 1^{\mathrm{a}}$ & $53 \pm 1^{a}$ & $80 \pm 10^{b}$ & $11 \pm 0.1^{b}$ & $35 \pm 1^{\mathrm{a}}$ & $17.4 \pm 0.2^{b}$ & $32 \pm 1^{\mathrm{ab}}$ & $29 \pm 1^{\mathrm{a}}$ \\
\hline & E3 & $27 \pm 1^{a}$ & $23 \pm 1^{\mathrm{a}}$ & $51 \pm 3^{a}$ & $57 \pm 4^{a}$ & $9.4 \pm 0.4^{\mathrm{a}}$ & $36 \pm 2^{\mathrm{a}}$ & $13 \pm 1^{\mathrm{a}}$ & $28 \pm 0.1^{a}$ & $26 \pm 1^{a}$ \\
\hline \multirow{4}{*}{ White bean } & C & $52 \pm 1^{b}$ & $40 \pm 2^{b}$ & $100 \pm 10^{\mathrm{b}}$ & $140 \pm 30^{\mathrm{b}}$ & $17 \pm 1^{c}$ & $64 \pm 4^{b}$ & $29 \pm 2^{c}$ & $50 \pm 1^{c}$ & $48 \pm 3^{b}$ \\
\hline & E1 & $49 \pm 3^{a b}$ & $37 \pm 2^{\mathrm{ab}}$ & $84 \pm 2^{\mathrm{ab}}$ & $130 \pm 10^{b}$ & $15.9 \pm 0.3^{b}$ & $58 \pm 1^{\mathrm{ab}}$ & $27 \pm 1^{b c}$ & $48 \pm 2^{c}$ & $44 \pm 2^{\mathrm{ab}}$ \\
\hline & E2 & $49 \pm 1^{\mathrm{ab}}$ & $36 \pm 2^{a}$ & $81 \pm 5^{a}$ & $140 \pm 10^{b}$ & $15.2 \pm 0.5^{b}$ & $56 \pm 3^{a}$ & $26 \pm 1^{b}$ & $44 \pm 2^{b}$ & $42 \pm 2^{a}$ \\
\hline & E3 & $46 \pm 2^{\mathrm{a}}$ & $35 \pm 2^{a}$ & $80 \pm 10^{a}$ & $100 \pm 10^{\mathrm{a}}$ & $13.3 \pm 0.4^{\mathrm{a}}$ & $61 \pm 6^{\mathrm{ab}}$ & $21 \pm 1^{\mathrm{a}}$ & $41 \pm 1^{a}$ & $40 \pm 2^{a}$ \\
\hline \multirow{4}{*}{ Oats } & C & $53 \pm 2^{b}$ & $39 \pm 1^{b c}$ & $80 \pm 1^{\mathrm{ab}}$ & $120 \pm 10^{\mathrm{b}}$ & $19.3 \pm 0.3^{b}$ & $52 \pm 1^{b}$ & $30 \pm 2^{b}$ & $59 \pm 2^{b}$ & $54 \pm 1^{b}$ \\
\hline & E1 & $56 \pm 3^{b}$ & $48 \pm 7^{c}$ & $100 \pm 30^{b}$ & $130 \pm 20^{\mathrm{b}}$ & $20 \pm 1^{b}$ & $55 \pm 3^{b}$ & $33 \pm 3^{b}$ & $65 \pm 1^{b}$ & $58 \pm 4^{a}$ \\
\hline & E2 & $53 \pm 6^{b}$ & $36 \pm 5^{b}$ & $80 \pm 10^{b}$ & $100 \pm 20^{\mathrm{b}}$ & $18 \pm 2^{b}$ & $50 \pm 6^{b}$ & $29 \pm 4^{b}$ & $59 \pm 8^{b}$ & $51 \pm 8^{b}$ \\
\hline & E3 & $39 \pm 2^{a}$ & $26 \pm 3^{a}$ & $60 \pm 10^{a}$ & $70 \pm 10^{\mathrm{a}}$ & $14 \pm 1^{a}$ & $39 \pm 4^{a}$ & $19 \pm 2^{\mathrm{a}}$ & $46 \pm 3^{a}$ & $39 \pm 5^{a}$ \\
\hline \multirow{4}{*}{ Spelt } & C & $58 \pm 4^{b}$ & $43 \pm 1^{b}$ & $87 \pm 2^{b}$ & $110 \pm 10^{b}$ & $21.3 \pm 0.3^{c}$ & $55 \pm 2^{b}$ & $32 \pm 2^{b}$ & $60 \pm 4^{b}$ & $57 \pm 2^{b}$ \\
\hline & E1 & $60 \pm 1^{b}$ & $43 \pm 1^{b}$ & $87 \pm 2^{b}$ & $117 \pm 3^{b}$ & $21 \pm 1^{b c}$ & $56 \pm 2^{b}$ & $33 \pm 1^{b}$ & $61 \pm 1^{b}$ & $58 \pm 1^{b}$ \\
\hline & E2 & $60 \pm 2^{b}$ & $42 \pm 2^{b}$ & $86 \pm 4^{b}$ & $100 \pm 20^{b}$ & $20 \pm 1^{b}$ & $56 \pm 2^{b}$ & $31 \pm 3^{b}$ & $57 \pm 3^{b}$ & $55 \pm 3^{b}$ \\
\hline & E3 & $42 \pm 1^{a}$ & $30 \pm 1^{\mathrm{a}}$ & $60 \pm 2^{a}$ & $67 \pm 4^{a}$ & $15.5 \pm 0.2^{\mathrm{a}}$ & $42 \pm 1^{a}$ & $19 \pm 1^{a}$ & $42 \pm 2^{\mathrm{a}}$ & $39 \pm 2^{a}$ \\
\hline \multirow{4}{*}{ Quinoa } & C & $60 \pm 1^{b}$ & $43 \pm 3^{c}$ & $84 \pm 3^{c}$ & $130 \pm 10^{b}$ & $22.6 \pm 0.5^{c}$ & $54 \pm 1^{c}$ & $34 \pm 2^{c}$ & $62 \pm 1^{c}$ & $58 \pm 3^{c}$ \\
\hline & E1 & $57 \pm 4^{b}$ & $37 \pm 3^{b}$ & $80 \pm 10^{b}$ & $120 \pm 20^{b}$ & $21 \pm 1^{b}$ & $51 \pm 3^{b c}$ & $30 \pm 2^{b}$ & $61 \pm 2^{c}$ & $50 \pm 2^{b}$ \\
\hline & E2 & $56 \pm 3^{b}$ & $35 \pm 2^{b}$ & $72 \pm 4^{b}$ & $122 \pm 14^{b}$ & $20 \pm 1^{b}$ & $48 \pm 3^{b}$ & $30 \pm 2^{b}$ & $56 \pm 3^{b}$ & $48 \pm 2^{b}$ \\
\hline & E3 & $42 \pm 2^{\mathrm{a}}$ & $25 \pm 2^{\mathrm{a}}$ & $50 \pm 4^{a}$ & $79 \pm 10^{\mathrm{a}}$ & $16 \pm 1^{\mathrm{a}}$ & $36 \pm 3^{a}$ & $19 \pm 2^{\mathrm{a}}$ & $43 \pm 2^{\mathrm{a}}$ & $34 \pm 3^{a}$ \\
\hline
\end{tabular}

249

Data shown are mean values from triplicates and the standard deviation. abc Different lowercase letters indicate significant differences between digestion models, with a significance level of $95 \%(p<0.05)$. 
Table 5.5.4. NEAA profile (mg FAA/g protein) of oats, spelt, quinoa, chickpea, lentils, soya bean and white bean after in vitro digestion using different elderly digestion models.

\begin{tabular}{|c|c|c|c|c|c|c|c|c|c|c|}
\hline \multirow{2}{*}{$\begin{array}{c}\text { Vegetal } \\
\text { food }\end{array}$} & \multirow{2}{*}{ GI conditions } & \multicolumn{9}{|c|}{ Non-essential amino acids (mg amino acid/g protein) } \\
\hline & & Alanine & Asparagine & Aspartic acid & Cystine & Glutamic acid & Glycine & Proline & Serine & Tyrosine \\
\hline \multirow{4}{*}{ Chickpea } & 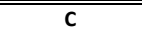 & $34 \pm 4^{\mathrm{b}}$ & $35 \pm 4^{\mathrm{a}}$ & $22 \pm 3^{\mathrm{a}}$ & $65 \pm 7^{\mathrm{b}}$ & $50 \pm 10^{b}$ & $18 \pm 2^{\mathrm{b}}$ & $13 \pm 1^{\mathrm{b}}$ & $36 \pm 4^{\mathrm{b}}$ & $120 \pm 10^{\mathrm{b}}$ \\
\hline & E1 & $29 \pm 1^{\mathrm{b}}$ & $30 \pm 2^{\mathrm{a}}$ & $19 \pm 1^{\text {a }}$ & $59 \pm 5^{b}$ & $42 \pm 8^{b}$ & $16 \pm 1^{b}$ & $11 \pm 1^{\text {ab }}$ & $32 \pm 1^{\mathrm{b}}$ & $101 \pm 4^{\mathrm{a}}$ \\
\hline & E2 & $31 \pm 4^{b}$ & $29 \pm 6^{\mathrm{a}}$ & $22 \pm 1^{\mathrm{a}}$ & $63 \pm 5^{b}$ & $47 \pm 9^{b}$ & $17 \pm 1^{b}$ & $12 \pm 1^{b}$ & $34 \pm 4^{b}$ & $100 \pm 10^{\mathrm{a}}$ \\
\hline & E3 & $18.8 \pm 0.3^{\mathrm{a}}$ & - & - & $35 \pm 1^{\text {a }}$ & $16 \pm 1^{\mathrm{a}}$ & $10.0 \pm 0.2^{\mathrm{a}}$ & $10.3 \pm 0.3^{\mathrm{a}}$ & $9.1 \pm 0.5^{\mathrm{a}}$ & $104 \pm 4^{\mathrm{a}}$ \\
\hline \multirow{4}{*}{ Lentils } & C & $27 \pm 2^{b}$ & $31 \pm 3^{a}$ & $20 \pm 1^{\mathrm{a}}$ & $48 \pm 3^{b}$ & $41 \pm 5^{b}$ & $15 \pm 1^{b}$ & $9 \pm 1^{b}$ & $27 \pm 2^{\mathrm{a}}$ & $100 \pm 30^{b}$ \\
\hline & E1 & $26 \pm 2^{b}$ & $30 \pm 2^{\mathrm{a}}$ & $20 \pm 1^{\mathrm{a}}$ & $48 \pm 2^{b}$ & $44 \pm 5^{b}$ & $14 \pm 1^{b}$ & $9.3 \pm 0.4^{b}$ & $26 \pm 2^{\mathrm{a}}$ & $87 \pm 2^{\mathrm{ab}}$ \\
\hline & E2 & $26 \pm 2^{b}$ & $26 \pm 3^{a}$ & $20 \pm 1^{\mathrm{a}}$ & $4.3 \pm 0^{\mathrm{a}}$ & $40 \pm 8^{b}$ & $15 \pm 1^{b}$ & $9.9 \pm 0.3^{b}$ & $26 \pm 2^{\mathrm{a}}$ & $83 \pm 3^{a}$ \\
\hline & E3 & $18 \pm 1^{\mathrm{a}}$ & - & - & - & $21 \pm 2^{\mathrm{a}}$ & $8.9 \pm 0.4^{\mathrm{a}}$ & $8.2 \pm 0.2^{\mathrm{a}}$ & - & $99 \pm 3^{\mathrm{ab}}$ \\
\hline \multirow{4}{*}{ Soya bean } & C & $18.9 \pm 0.2^{b}$ & $20 \pm 1^{\mathrm{a}}$ & $12 \pm 1^{\mathrm{a}}$ & $35 \pm 2^{b}$ & $25 \pm 3^{b}$ & $9.9 \pm 0.2^{b}$ & $6.9 \pm 0.3^{\mathrm{ab}}$ & $20 \pm 1^{\mathrm{a}}$ & $82 \pm 7^{b}$ \\
\hline & E1 & $19 \pm 2^{b}$ & $20 \pm 3^{\mathrm{a}}$ & $13 \pm 2^{\mathrm{a}}$ & $36 \pm 5^{b}$ & $30 \pm 3^{c}$ & $10 \pm 1^{b}$ & $7 \pm 1^{\mathrm{ab}}$ & $20 \pm 2^{\mathrm{a}}$ & $66 \pm 9^{a}$ \\
\hline & E2 & $19 \pm 1^{b}$ & $18.8 \pm 0.4^{\mathrm{a}}$ & $12.2 \pm 0.5^{a}$ & $35.9 \pm 0.3^{b}$ & $30 \pm 2^{b c}$ & $10.2 \pm 0.2^{b}$ & $7.5 \pm 0.1^{b}$ & $20.3 \pm 0.3^{\mathrm{a}}$ & $59 \pm 2^{\mathrm{a}}$ \\
\hline & E3 & $13 \pm 1^{\mathrm{a}}$ & - & - & $20.6 \pm 0.02^{\mathrm{a}}$ & $12 \pm 2^{\mathrm{a}}$ & $6.3 \pm 0.2^{\mathrm{a}}$ & $6.4 \pm 0.5^{\mathrm{a}}$ & - & $63.8 \pm 0.2^{\mathrm{a}}$ \\
\hline \multirow{4}{*}{ White bean } & C & $31 \pm 2^{c}$ & $31 \pm 4^{b}$ & $20 \pm 1^{b}$ & $55 \pm 2^{\mathrm{b}}$ & $47 \pm 2^{b}$ & $16.5 \pm 0.5^{c}$ & $10.2 \pm 0.1^{b}$ & $34 \pm 3^{b}$ & $130 \pm 10^{c}$ \\
\hline & E1 & $28 \pm 1^{b c}$ & $29 \pm 2^{b}$ & $19 \pm 1^{b}$ & $53 \pm 3^{b}$ & $45 \pm 5^{b}$ & $15.5 \pm 0.4^{b c}$ & $10 \pm 0.4^{b}$ & $31 \pm 1^{b}$ & $100 \pm 10^{\mathrm{a}}$ \\
\hline & E2 & $27 \pm 2^{\mathrm{b}}$ & $27 \pm 2^{\mathrm{b}}$ & $19 \pm 1^{b}$ & $52 \pm 2^{b}$ & $48 \pm 7^{b}$ & $15 \pm 1^{\mathrm{b}}$ & $10.1 \pm 0.3^{b}$ & $31 \pm 2^{b}$ & $109 \pm 2^{\mathrm{ab}}$ \\
\hline & E3 & $21 \pm 1^{\mathrm{a}}$ & $8 \pm 2^{\mathrm{a}}$ & $2 \pm 0.4^{\mathrm{a}}$ & $34 \pm 2^{\mathrm{a}}$ & $27 \pm 2^{\mathrm{a}}$ & $10.4 \pm 0.3^{\mathrm{a}}$ & $8.6 \pm 0.03^{a}$ & $13 \pm 3^{a}$ & $130 \pm 10^{\mathrm{bc}}$ \\
\hline \multirow{4}{*}{ Oats } & C & $35 \pm 2^{b}$ & $30 \pm 4^{\mathrm{a}}$ & $23 \pm 1^{b}$ & $82 \pm 3^{b}$ & $55 \pm 1^{b}$ & $21 \pm 1^{\mathrm{b}}$ & $16 \pm 1^{\mathrm{ab}}$ & $37 \pm 3^{b}$ & $160 \pm 10^{b}$ \\
\hline & E1 & $38 \pm 4^{\mathrm{a}}$ & $34 \pm 5^{a}$ & $27 \pm 3^{b}$ & $90 \pm 6^{b}$ & $58 \pm 4^{b}$ & $24 \pm 2^{b}$ & $18 \pm 1^{b}$ & $40 \pm 5^{b}$ & $170 \pm 20^{b}$ \\
\hline & E2 & $33 \pm 5^{b}$ & $27 \pm 3^{a}$ & $24 \pm 3^{b}$ & $86 \pm 11^{b}$ & $50 \pm 10^{b}$ & $22 \pm 3^{b}$ & $17 \pm 2^{b}$ & $36 \pm 5^{b}$ & $160 \pm 20^{b}$ \\
\hline & E3 & $22 \pm 3^{a}$ & - & $6 \pm 5^{a}$ & $56 \pm 3^{\mathrm{a}}$ & $18 \pm 5^{a}$ & $14 \pm 1^{\mathrm{a}}$ & $14 \pm 1^{\mathrm{a}}$ & $17 \pm 4^{\mathrm{a}}$ & $120 \pm 10^{a}$ \\
\hline \multirow{4}{*}{ Spelt } & C & $35 \pm 1^{b}$ & $28 \pm 4^{a b}$ & $23 \pm 3^{a}$ & $97 \pm 7^{b}$ & $50 \pm 10^{b}$ & $20 \pm 1^{b}$ & $19 \pm 1^{\mathrm{a}}$ & $40 \pm 4^{a}$ & $160 \pm 10^{b}$ \\
\hline & E1 & $34.9 \pm 0.5^{b}$ & $30 \pm 2^{b}$ & $25 \pm 1^{\mathrm{a}}$ & $102 \pm 2^{b}$ & $63 \pm 6^{b}$ & $21.0 \pm 0.5^{b}$ & $19.7 \pm 0.5^{a b}$ & $41 \pm 2^{\mathrm{a}}$ & $150 \pm 10^{b}$ \\
\hline & E2 & $34 \pm 3^{b}$ & $22 \pm 5^{a}$ & $23 \pm 3^{\mathrm{a}}$ & $99 \pm 5^{b}$ & $60 \pm 10^{b}$ & $21 \pm 1^{\mathrm{b}}$ & $21 \pm 1^{b}$ & $39 \pm 4^{a}$ & $152 \pm 4^{b}$ \\
\hline & E3 & $22 \pm 1^{\mathrm{a}}$ & - & - & $64 \pm 1^{\mathrm{a}}$ & $30 \pm 2^{\mathrm{a}}$ & $12 \pm 1^{\mathrm{a}}$ & $20 \pm 1^{\text {ab }}$ & - & $122 \pm 3^{a}$ \\
\hline \multirow{4}{*}{ Quinoa } & C & $38 \pm 2^{c}$ & $32 \pm 3^{b}$ & $27 \pm 3^{a}$ & $92 \pm 5^{b}$ & $61 \pm 6^{c}$ & $22 \pm 1^{c}$ & $16 \pm 1^{b}$ & $39 \pm 3^{b}$ & $154 \pm 4^{b}$ \\
\hline & E1 & $33 \pm 2^{b}$ & $28 \pm 2^{a b}$ & $23 \pm 2^{\mathrm{a}}$ & $89 \pm 5^{b}$ & $47 \pm 7^{b}$ & $20 \pm 1^{b c}$ & $15 \pm 1^{b}$ & $34 \pm 2^{\mathrm{a}}$ & $150 \pm 10^{b}$ \\
\hline & E2 & $32 \pm 1^{b}$ & $25 \pm 2^{\mathrm{a}}$ & $25 \pm 2^{\mathrm{a}}$ & $83 \pm 5^{b}$ & $49 \pm 2^{b}$ & $20 \pm 1^{b}$ & $15 \pm 1^{b}$ & $34 \pm 1^{\mathrm{a}}$ & $150 \pm 10^{b}$ \\
\hline & E3 & $20 \pm 2^{\mathrm{a}}$ & - & - & $55 \pm 5^{a}$ & $19 \pm 5^{a}$ & $13 \pm 1^{\mathrm{a}}$ & $12 \pm 1^{\mathrm{a}}$ & - & $110 \pm 10^{\mathrm{a}}$ \\
\hline
\end{tabular}

Data shown are mean values from triplicates and the standard deviation. abc Different lowercase letters indicate significant differences

between digestion models in each grain, with a significance level of $95 \%(p<0.05)$. 


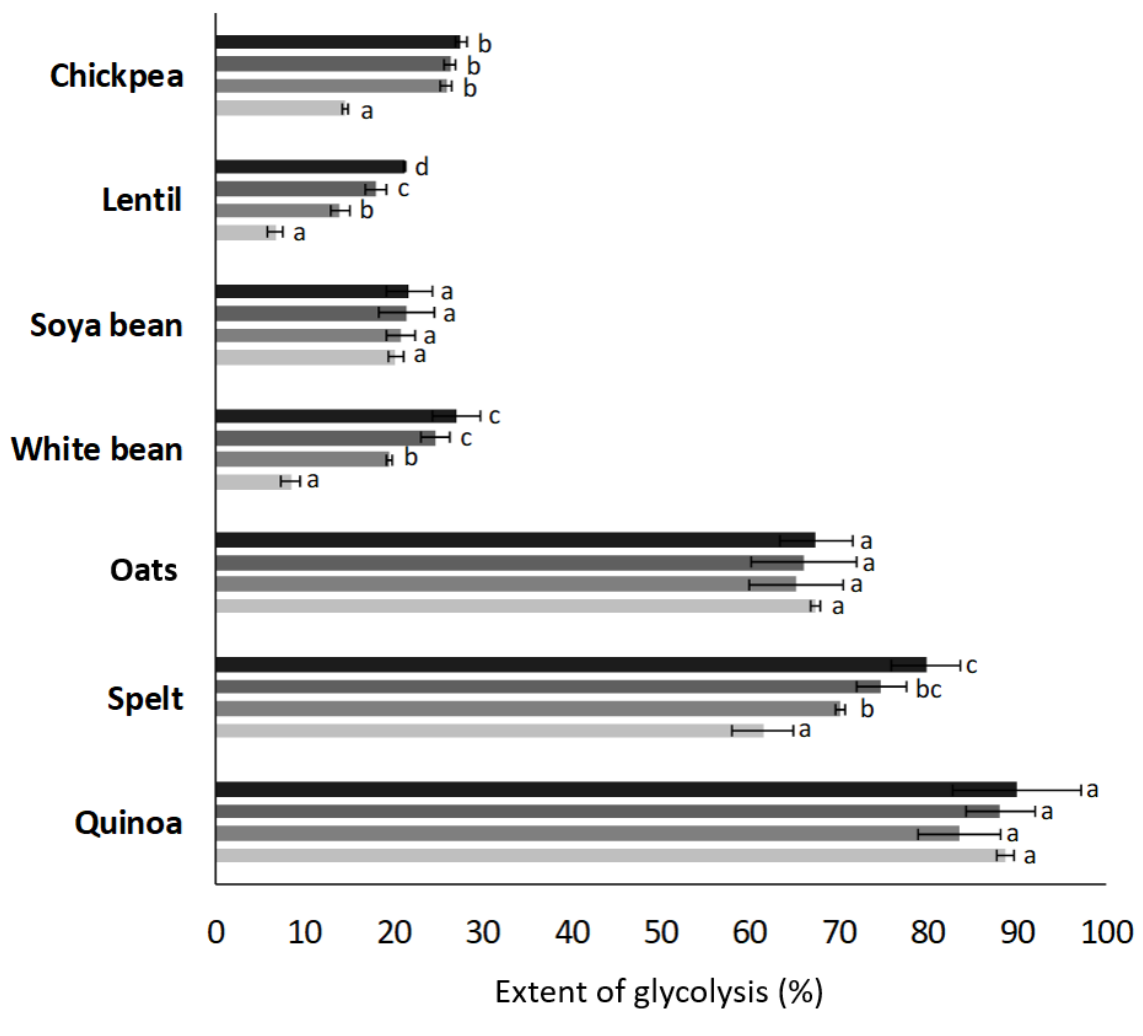

$\square \mathrm{C} \square \mathrm{E} 1 \mathrm{E} 2 \square \mathrm{E} 3$

Figure 5.5.2. Extent of glycolysis (\%) in cooked legumes (chickpea, lentil, soya bean and white bean) and grains (oats, spelt and quinoa) obtained with different in vitro digestion models (C, E1, E2 and E3). Data presented as $g$ of free glucose $E / 100 \mathrm{~g}$ initial starch. ${ }^{a b c}$ Different lowercase letters indicate significant differences among digestion models with a significance level of 95\% ( $p<0.05)$.

variability of starch digestibility in legumes and grains, it has been consistent that legume starch is hydrolyzed to a much lesser extent than starch in oats, spelt or quinoa. The starch digestibility increases when subjected to thermal 
processes ${ }^{56}$ and depends on the severity of the process, i.e., the damage done to the starch granules could vary ${ }^{57}$. Hence, the starch thermal behavior differs between legumes and cereals ${ }^{58}$. The intrinsic characteristics of the plant source could make a difference in terms of starch digestibility. Consequently, the lower digestibility of legume starch, compared to cereal starches, could be attributed to the higher amylose content, existence of intact tissue/cell structures enclosing starch granules, higher content of viscous soluble dietary fiber components, the incidence of a larger number of antinutrients which would affect starch digestion, ' $B$ 'type crystallites and stronger interactions between amylose chains ${ }^{56,59}$.

On the other hand, the elderly oral alterations (C compared to E1) had a statistically significant $(p<0.05)$ negative impact on starch hydrolysis in lentils only; even when a declining trend was observed in other legumes and cereal/pseudocereal grains such as chickpea, soya bean, white bean and spelt. Higher protein content has been associated with strong molecular interactions ${ }^{51}$, and the decrease in chewing cycles can impact digestion differently depending on the intrinsic properties of each food (particle size, hardness and other physical properties) ${ }^{60}$. Likewise, the gastric alterations seem to decrease starch digestibility in all legumes and grains, only being statistically significant for lentil and white bean. Proteins can decrease the enzymatic digestion of starch due to the three-dimensional network they form ${ }^{61}$. Subsequently, if the gastric proteolytic enzyme concentration is reduced (E2), food matrix degradation throughout digestion is expected to fall along with the conversion of starch into sugars. Finally, the elderly intestinal disorders (E3) highly contributed to a remarkable reduction of glycolysis for all legumes and grains, except for soya bean, oats and quinoa in which sugar content resulting from starch hydrolysis was similar to the obtained with healthy GI conditions (C). Carbohydrate digestibility of spelt, chickpea, lentils and white bean was more affected by bile and pancreatic enzyme concentrations than by the time of digestion. On the other hand, it 
is important to point out that oats and quinoa glycolysis seems to increase when E3 conditions were simulated. Lower fiber and protein contents in cooked oats and quinoa grains promote lower viscosity, leading to easier and more digestible matrices in a shorter time ${ }^{61,62}$, especially when they are subjected to the most disadvantageous GI scenery (E3). The legumes could have a greater contribution to hypoglycemia than oats, quinoa and spelt ${ }^{63}$.

\section{Calcium bioaccessibility of legumes and grains using the elderly GI conditions}

A diminished digestion of macronutrients, such as proteins and carbohydrates, could lead to a deficient release and solubilization of micronutrients. Results showed that calcium bioaccessibility (\%) was much higher in cereals/pseudocereals (from 82 to 103\%) than in legumes (from 34 to $65 \%$ ) in $\mathrm{C}$ conditions (Figure 5.5.3). There are very few studies on calcium bioaccessibility in legumes and grains and none simulating the elderly GI conditions. Ramírez-Ojeda et al. (2018) ${ }^{6}$ reported similar values of calcium bioaccessibility for lentil, chickpea and white bean. Legumes are specially high in antinutrients such as phytates, oxalates and tannins that can form insoluble complexes with calcium ${ }^{64}$. Phytates, are directly related to fiber ${ }^{64}$ and protein ${ }^{35}$ contents exerting an adverse effect on calcium absorption. Additionally, some believe that lipids produce insoluble soaps with calcium, lowering its bioavailability ${ }^{64}$. The higher the protein, fiber and fat contents in legumes, the lower the calcium bioaccessibility. High phytates amounts present in both food groups ${ }^{65}$ could be affected during processing and cooking. Moreover, phytase is an enzyme found in cereal and legumes which has optimal enzymatic activity in an acidic $\mathrm{pH}$ (4.5-5.6) in cereal, and in a neutral or an alkaline $\mathrm{pH}$ in legumes ${ }^{33}$. Consequently, the lower enzymatic activity at gastric pH can affect calcium's GI pathway. Therefore, calcium bioaccessibility was affected with oral alterations for lentil and white bean, gastric alterations for white bean and oats, and intestinal changes for all. Intestinal suboptimal conditions drastically decreased 
calcium release in all samples except chickpea. A reduction of up to $53 \%$ was observed in some cases. Despite the reduction in calcium release from legumes and grains using the elderly conditions, chickpea, soya bean, white bean and oats are still good sources of this mineral in its bioaccessible form. The elderly are recommended to increase calcium intake since bone density tends to decrease with age leading to osteopenia and osteoporosis ${ }^{66}$. The latter is a significant health problem that contributes to disability and premature mortality amongst women and older men. Although genetic factors influence maximum bone mass, diet and exercise are modifiable risk factors that can be targeted to prevent osteoporosis ${ }^{2}$.

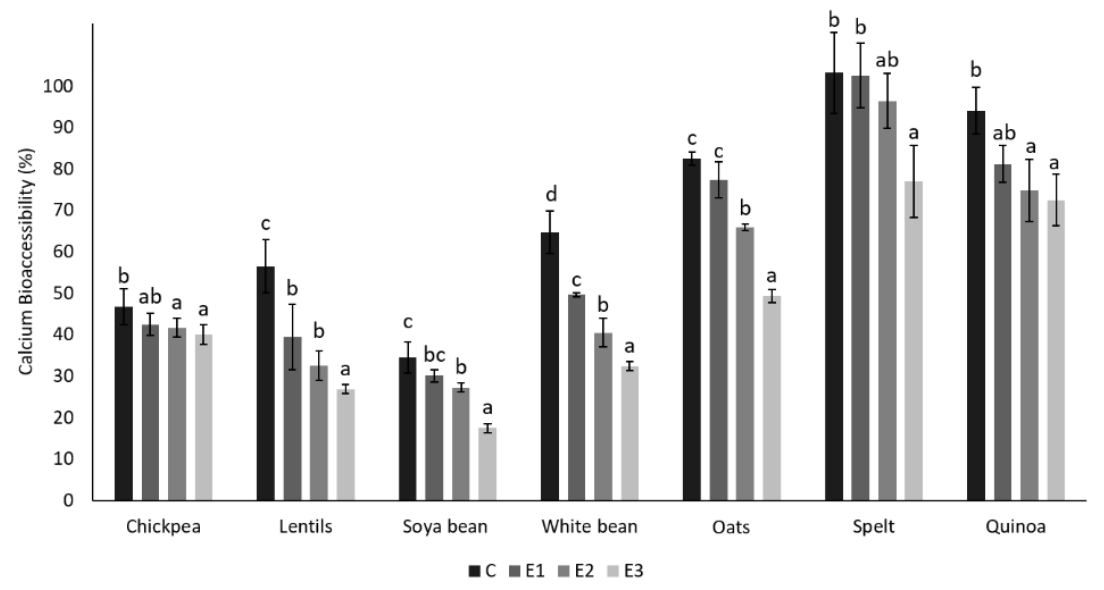

Figure 5.5.3. Calcium bioaccessibility (\%) of cooked legumes (chickpea, lentils, soya bean and white bean) and grains (oats, spelt, quinoa) digested with different in vitro digestion models (C, E1, E2 and E3). ${ }^{a b c}$ Different lowercase letters indicate significant differences among digestion models with a significance level of $95 \%(p<0.05)$.

Descriptive relationship among digestion-end-parameters and the elderly GI conditions 
Figure 5.5.4 shows the amount of EAA and NEAA (\%), and the extents of proteolysis (\%), glycolysis (\%) and calcium bioaccessibility (\%), as well as the scores for the different legumes and grains with the different simulated GI conditions. The first two main components explain $92.1 \%$ of the total variance in macronutrients and calcium bioaccessibility percentages in the samples (PC1: 69.9\% and PC2: 22.2\%). In the score plot, the proximity between samples indicates similar behavior in terms of digestibility. PC1 distinguishes among grains (oats, spelt and quinoa), located at the upper right quadrant of the plot, and legumes (chickpea, lentils, soya bean and white bean) located at the left lower quadrant of the plot. Besides, PCA showed the narrow relationship between the extent of glycolysis, NEAA and calcium bioaccessibility; while PC2 seems to distinguish between chickpea

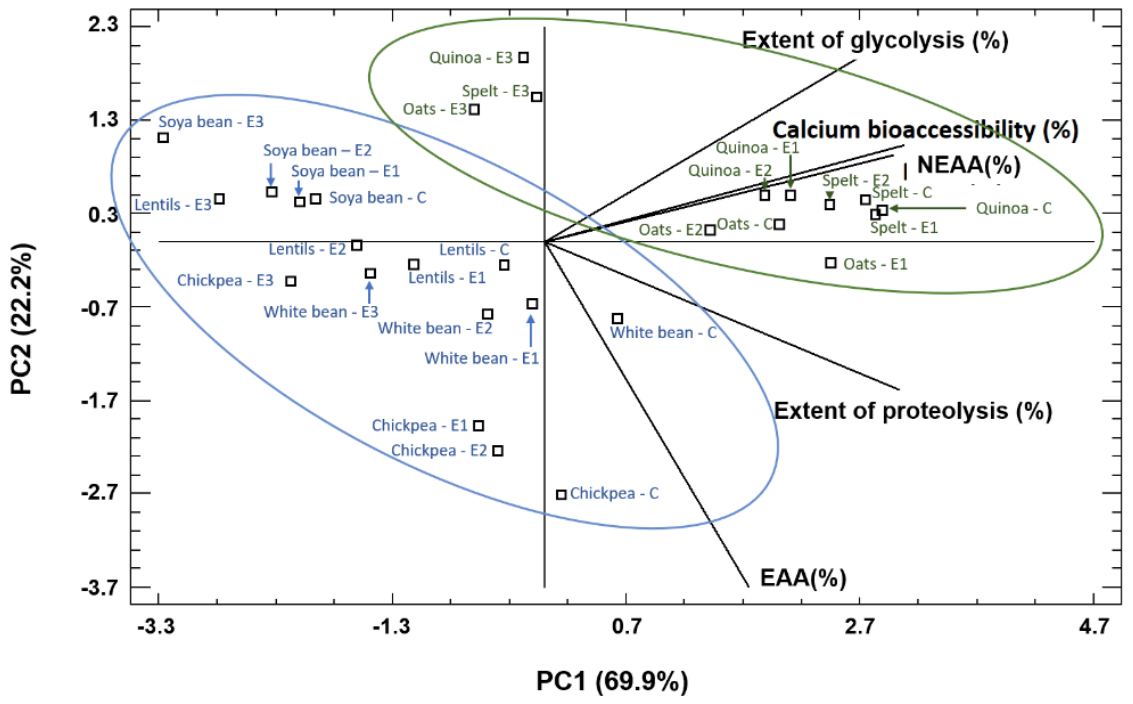

Figure 5.5.4. Biplot of the different end-products resulting from digestion and their relationship with the legume/grain samples (chickpea, lentils, soya bean, white bean, oats, spelt and quinoa) and the GI conditions (C, E1, E2 and E3) using principal components analysis (PCA). 
and soya bean from other legumes and cereals in terms of the amount of EAA and the total extent of proteolysis (higher in chickpea and lower in soya bean, than in the other matrices). Finally, PCA showed that as the digestive $\mathrm{Gl}$ conditions were altered according to the elderly disorders (from the $\mathrm{C}$ to E3 models), samples tended to move towards the left side of the graph.

\section{CONCLUSIONS}

The influence of oral, gastric and/or intestinal alterations appearing with ageing on the luminal digestion of different legumes (chickpea, lentils, soya bean and white bean) and cereal/pseudocereal (oats, spelt and quinoa) grains were analyzed. According to the main results, it can be concluded that oats, spelt and quinoa proteins are more digestible than legumes with healthy GI conditions. Using the elderly GI alterations, and especially when intestinal conditions are suboptimal, proteolysis in grains seems to be, however, more compromised than in legumes. In addition, a preferential release of EAA compared to that of NEAA has been observed when the elderly $\mathrm{GI}$ conditions were simulated.

With respect to glycolysis and calcium bioaccessibility, the elderly intestinal alterations reduced the extent of glycolysis in legumes and spelt compared to the hydrolysis of starch achieved with healthy $\mathrm{Gl}$ conditions. Cereal/pseudocereal grains have been shown to be a greater source of its bioaccessible form than legumes regardless the GI conditions. Although a notable bioaccessibility reduction was found in some foods such as chickpea, oats, soya and white beans as a consequence of the elderly GI alterations, they can still be considered good sources of bioaccessible calcium compared to other vegetal foods.

To conclude, these results support the idea that diet recommendations concerning the consumption of legumes and cereal/pseudocereal grains need to consider the impact of Gl conditions of the populations of concern (e.g., the elderly) on their digestibility. 


\section{REFERENCES}

(1) UN. World Population Prospects 2019: Highlights (St/Esa/Ser. A/423). 2019.

(2) Rémond, D.; Shahar, D. R.; Gille, D.; Pinto, P.; Kachal, J.; Peyron, M. A.; Dos Santos, C. N.; Walther, B.; Bordoni, A.; Dupont, D.; TomásCobos, L.; Vergères, G. Understanding the Gastrointestinal Tract of the Elderly to Develop Dietary Solutions That Prevent Malnutrition. Oncotarget 2015, 6 (16), 13858-13898. https://doi.org/10.18632/oncotarget.4030.

(3) De-la-O, A.; Jurado-Fasoli, L.; Castillo, M. J.; Gracia-Marco, L.; Gutierrez, Á.; Amaro-Gahete, F. J. Relationship between 1,25Dihydroxyvitamin $D$ and Body Composition in Middle-Aged Sedentary Adults: The FIT-AGEING Study. Nutrients 2019, 11 (11), 2567. https://doi.org/10.3390/nu11112567.

(4) FAO. Fact sheets | 2016 International Year of Pulses http://www.fao.org/pulses-2016/communications-toolkit/factsheets/en/ (accessed Apr 2, 2020).

(5) Giusti, F.; Capuano, E.; Sagratini, G.; Pellegrini, N. A Comprehensive Investigation of the Behaviour of Phenolic Compounds in Legumes during Domestic Cooking and in Vitro Digestion. Food Chemistry 2019, 285, 458-467. https://doi.org/10.1016/j.foodchem.2019.01.148.

(6) Ramírez-Ojeda, A. M.; Moreno-Rojas, R.; Cámara-Martos, F. Mineral and Trace Element Content in Legumes (Lentils, Chickpeas and Beans): Bioaccesibility and Probabilistic Assessment of the Dietary Intake. Journal of Food Composition and Analysis 2018, 73, 17-28. https://doi.org/10.1016/j.jfca.2018.07.007.

(7) Roy, F.; Boye, J. I.; Simpson, B. K. Bioactive Proteins and Peptides in Pulse Crops: Pea, Chickpea and Lentil. Food Research International. Elsevier March 1, 2010, pp 432-442. https://doi.org/10.1016/j.foodres.2009.09.002. 
(8) Esmaillzadeh, A.; Azadbakht, L. Legume Consumption Is Inversely Associated with Serum Concentrations of Adhesion Molecules and Inflammatory Biomarkers among Iranian Women. Journal of $\begin{array}{llll}\text { Nutrition } & \text { 2012, } & 142 & \text { (2), }\end{array}$ https://doi.org/10.3945/jn.111.146167.

(9) Jeong, D.; Han, J. A.; Liu, Q.; Chung, H. J. Effect of Processing, Storage, and Modification on in Vitro Starch Digestion Characteristics of Food Legumes: A Review. Food Hydrocolloids. Elsevier B.V. May 1, 2019, pp 367-376. https://doi.org/10.1016/j.foodhyd.2018.12.039.

(10) Monnet, A. F.; Laleg, K.; Michon, C.; Micard, V. Legume Enriched Cereal Products: A Generic Approach Derived from Material Science to Predict Their Structuring by the Process and Their Final Properties. Trends in Food Science and Technology. Elsevier Ltd April 1, 2019, pp 131-143. https://doi.org/10.1016/j.tifs.2019.02.027.

(11) Stoin, D.; Petrovich, L. I.; Velciov, A.-B.; Cozma, A.; Trasca, T.; Rivis, A.; Jianu, C. Red Kidney Bean and Rice Flours: Potential Ingredients in the Production of Gluten-Free Bread with Functional Quality; 2019; Vol. 25.

(12) Yabe, S.; Iwata, H. Genomics-Assisted Breeding in Minor and PseudoCereals. Breeding Science. 2020, pp 19-31. https://doi.org/10.1270/jsbbs.19100.

(13) Capurso, A.; Crepaldi, G.; Capurso, C. Cereals. In Benefits of the Mediterranean Diet in the Elderly Patient; Springer International Publishing: Padua, Italy, 2018; pp 139-172. https://doi.org/10.1007/978-3-319-78084-9_8.

(14) Rodríguez, J. P.; Rahman, H.; Thushar, S.; Singh, R. K. Healthy and Resilient Cereals and Pseudo-Cereals for Marginal Agriculture: Molecular Advances for Improving Nutrient Bioavailability. Frontiers in Genetics. Frontiers February 27, 2020, p 49. https://doi.org/10.3389/fgene.2020.00049.

(15) Comai, S.; Bertazzo, A.; Bailoni, L.; Zancato, M.; Costa, C. V. L.; Allegri, 
G. The Content of Proteic and Nonproteic (Free and Protein-Bound) Tryptophan in Quinoa and Cereal Flours. Food Chemistry 2007, 100 (4), 1350-1355. https://doi.org/10.1016/j.foodchem.2005.10.072.

(16) Dakhili, S.; Abdolalizadeh, L.; Hosseini, S. M.; Shojaee-Aliabadi, S.; Mirmoghtadaie, L. Quinoa Protein: Composition, Structure and Functional Properties. Food Chemistry. Elsevier Ltd 2019, p 125161. https://doi.org/10.1016/j.foodchem.2019.125161.

(17) Satusap, P.; Chavasit, V.; Kriengsinyos, W.; Judprasong, K. Development of Cereal and Legume Based Food Products for the Elderly. SpringerPlus 2014, 3 (1), 451. https://doi.org/10.1186/21931801-3-451.

(18) Association of Official Analysis Chemists International (AOAC). Official Methods of Analysis of AOAC International. Association of Official Analysis Chemists International 2000, Method ce 2-66. https://doi.org/10.3109/15563657608988149.

(19) Armellini, R.; Peinado, I.; Asensio-Grau, A.; Pittia, P.; Scampicchio, M.; Heredia, A.; Andres, A. In Vitro Starch Digestibility and Fate of Crocins in Pasta Enriched with Saffron Extract. Food Chemistry 2019, 283, 155-163. https://doi.org/10.1016/j.foodchem.2019.01.041.

(20) Noël, L.; Carl, M.; Vastel, C.; Guérin, T. Determination of Sodium, Potassium, Calcium and Magnesium Content in Milk Products by Flame Atomic Absorption Spectrometry (FAAS): A Joint ISO/IDF Collaborative Study. International Dairy Journal 2008, 18 (9), 899904. https://doi.org/10.1016/j.idairyj.2008.01.003.

(21) Minekus, M.; Alminger, M.; Alvito, P.; Ballance, S.; Bohn, T.; Bourlieu, C.; Carrière, F.; Boutrou, R.; Corredig, M.; Dupont, D.; Dufour, C.; Egger, L.; Golding, M.; Karakaya, S.; Kirkhus, B.; Le Feunteun, S.; Lesmes, U.; Maclerzanka, A.; MacKie, A.; Marze, S.; McClements, D. J.; Ménard, O.; Recio, I.; Santos, C. N.; Singh, R. P.; Vegarud, G. E.; Wickham, M. S. J.; Weitschies, W.; Brodkorb, A. A Standardised Static in Vitro Digestion Method Suitable for Food-an International Consensus. Food and Function 2014, 5 (6), 1113-1124. 
https://doi.org/10.1039/c3fo60702j.

(22) Shani-Levi, C.; Alvito, P.; Andrés, A.; Assunção, R.; Barberá, R.; Blanquet-Diot, S.; Bourlieu, C.; Brodkorb, A.; Cilla, A.; Deglaire, A.; Denis, S.; Dupont, D.; Heredia, A.; Karakaya, S.; Giosafatto, C. V. L.; Mariniello, L.; Martins, C.; Ménard, O.; El, S. N.; Vegarud, G. E.; Ulleberg, E.; Lesmes, U. Extending in Vitro Digestion Models to Specific Human Populations: Perspectives, Practical Tools and BioRelevant Information. Trends in Food Science and Technology. Elsevier February 1, 2017, pp 52-63. https://doi.org/10.1016/j.tifs.2016.10.017.

(23) Denis, S.; Sayd, T.; Georges, A.; Chambon, C.; Chalancon, S.; SantéLhoutellier, V.; Blanquet-Diot, S. Digestion of Cooked Meat Proteins Is Slightly Affected by Age as Assessed Using the Dynamic Gastrointestinal TIM Model and Mass Spectrometry. Food and Function 2016, 7 (6), 2682-2691. https://doi.org/10.1039/c6fo00120c.

(24) Jalabert-Malbos, M. L.; Mishellany-Dutour, A.; Woda, A.; Peyron, M. A. Particle Size Distribution in the Food Bolus after Mastication of Natural Foods. Food Quality and Preference 2007, 18 (5), 803-812. https://doi.org/10.1016/j.foodqual.2007.01.010.

(25) Lee, J. S.; Weyant, R. J.; Corby, P.; Kritchevsky, S. B.; Harris, T. B.; Rooks, R.; Rubin, S. M.; Newman, A. B. Edentulism and Nutritional Status in a Biracial Sample of Well-Functioning, Community-Dwelling Elderly: The Health, Aging, and Body Composition Study. American Journal of Clinical Nutrition 2004, 79 (2), 295-302. https://doi.org/10.1093/ajcn/79.2.295.

(26) O'Keeffe, M.; Kelly, M.; O’Herlihy, E.; O’Toole, P. W.; Kearney, P. M.; Timmons, S.; O'Shea, E.; Stanton, C.; Hickson, M.; Rolland, Y.; Sulmont Rossé, C.; Issanchou, S.; Maitre, I.; Stelmach-Mardas, M.; Nagel, G.; Flechtner-Mors, M.; Wolters, M.; Hebestreit, A.; De Groot, L. C. P. G. M.; van de Rest, O.; Teh, R.; Peyron, M. A.; Dardevet, D.; Papet, I.; Schindler, K.; Streicher, M.; Torbahn, G.; Kiesswetter, E.; 
Visser, M.; Volkert, D.; O'Connor, E. M. Potentially Modifiable Determinants of Malnutrition in Older Adults: A Systematic Review. Clinical Nutrition. Churchill Livingstone December 1, 2019, pp 24772498. https://doi.org/10.1016/j.clnu.2018.12.007.

(27) Peinado, I.; Koutsidis, G.; Ames, J. Production of Seafood Flavour Formulations from Enzymatic Hydrolysates of Fish By-Products. LWT - Food Science and Technology 2016, 66, 444-452. https://doi.org/10.1016/j.lwt.2015.09.025.

(28) Angioloni, A.; Collar, C. Nutritional and Functional Added Value of Oat, Kamut ${ }^{\circledR}$, Spelt, Rye and Buckwheat versus Common Wheat in Breadmaking. Journal of the Science of Food and Agriculture 2011, 91 (7), 1283-1292. https://doi.org/10.1002/jsfa.4314.

(29) Iqbal, A.; Khalil, I. A.; Ateeq, N.; Sayyar Khan, M. Nutritional Quality of Important Food Legumes. Food Chemistry 2006, 97 (2), 331-335. https://doi.org/10.1016/j.foodchem.2005.05.011.

(30) Longvah, T. Indian Food Composition Tables 2017; 2017.

(31) Pan, A.; Franco, O. H.; Ye, J.; Demark-Wahnefried, W.; Ye, X.; Yu, Z.; $\mathrm{Li}, \mathrm{H}$.; Lin, X. Soy Protein Intake Has Sex-Specific Effects on the Risk of Metabolic Syndrome in Middle-Aged and Elderly Chinese. Journal of Nutrition 2008, 138 (12), 2413-2421. https://doi.org/10.3945/jn.108.097519.

(32) Anitha, S.; Govindaraj, M.; Kane-Potaka, J. Balanced Amino Acid and Higher Micronutrients in Millets Complements Legumes for Improved Human Dietary Nutrition. Cereal Chemistry 2020, 97 (1), 74-84. https://doi.org/10.1002/cche.10227.

(33) Sandberg, A.-S. Bioavailability of Minerals in Legumes. British Journal of Nutrition 2002, 88 (S3), 281-285. https://doi.org/10.1079/bjn/2002718.

(34) U.S. Department of Agriculture, A. R. S. FoodData Central.

(35) Lestienne, I.; Icard-Vernière, C.; Mouquet, C.; Picq, C.; Trèche, S. 
Effects of Soaking Whole Cereal and Legume Seeds on Iron, Zinc and Phytate Contents. Food Chemistry 2005, 89 (3), 421-425. https://doi.org/10.1016/j.foodchem.2004.03.040.

(36) Volpi, E.; Kobayashi, H.; Sheffield-Moore, M.; Mittendorfer, B.; Wolfe, R. R. Essential Amino Acids Are Primarily Responsible for the Amino Acid Stimulation of Muscle Protein Anabolism in Healthy Elderly Adults. American Journal of Clinical Nutrition 2003, 78 (2), 250-258. https://doi.org/10.1093/ajcn/78.2.250.

(37) Walston, J. D. Sarcopenia in Older Adults. Current Opinion in Rheumatology. NIH Public Access November 2012, pp 623-627. https://doi.org/10.1097/BOR.0b013e328358d59b.

(38) Asensio-Grau, A.; Peinado, I.; Heredia, A.; Andrés, A. Effect of Cooking Methods and Intestinal Conditions on Lipolysis, Proteolysis and Xanthophylls Bioaccessibility of Eggs. Journal of Functional Foods 2018, 46, 579-586. https://doi.org/10.1016/j.jff.2018.05.025.

(39) Abdel-Aal, E. S. M.; Hucl, P. Amino Acid Composition and in Vitro Protein Digestibility of Selected Ancient Wheats and Their End Products. Journal of Food Composition and Analysis 2002, 15 (6), 737-747. https://doi.org/10.1006/jfca.2002.1094.

(40) Sobota, A.; Świeca, M.; Gęsiński, K.; Wirkijowska, A.; Bochnak, J. Yellow-Coated Quinoa (Chenopodium Quinoa Willd) Physicochemical, Nutritional, and Antioxidant Properties. Journal of the Science of Food and Agriculture 2020, 100 (5), 2035-2042. https://doi.org/10.1002/jsfa.10222.

(41) Zarkadas, C. G.; Yu, Z.; Burrows, V. D. Assessment of the Protein Quality of Two New Canadian-Developed Oat Cultivars by Amino Acid Analysis. Journal of Agricultural and Food Chemistry 1995, 43 (2), 422-428. https://doi.org/10.1021/jf00050a031.

(42) Hussain, A.; Iqbal, A.; Khan, Z. H.; Shah, F. Introductory Chapter: Recent Advances in Grain Crops Research. In Recent Advances in Grain Crops Research; Shah, F., Khan, Z., Iqbal, A., Turan, M., Olgun, 
M., Eds.; IntechOpen: 2020. https://doi.org/10.5772/intechopen.90701.

(43) Zahir, M.; Fogliano, V.; Capuano, E. Effect of Soybean Processing on Cell Wall Porosity and Protein Digestibility. In Food and Function; 2020; Vol. 11, pp 285-296. https://doi.org/10.1039/c9fo02167a.

(44) Zahir, M.; Fogliano, V.; Capuano, E. Food Matrix and Processing Modulate: In Vitro Protein Digestibility in Soybeans. Food and Function 2018, 9 (12), 6326-6336. https://doi.org/10.1039/c8fo01385c.

(45) Alajaji, S. A.; El-Adawy, T. A. Nutritional Composition of Chickpea (Cicer Arietinum L.) as Affected by Microwave Cooking and Other Traditional Cooking Methods. Journal of Food Composition and Analysis 2006, 19 (8), 806-812. https://doi.org/10.1016/j.jfca.2006.03.015.

(46) Koehler, P.; Wieser, H. Chemistry of Cereal Grains. In Handbook on Sourdough Biotechnology; Springer US, 2013; pp 11-45. https://doi.org/10.1007/978-1-4614-5425-0_2.

(47) Tsopmo, A. Processing Oats and Bioactive Components. In Processing and Impact on Active Components in Food; Elsevier Inc., 2015; pp 361-368. https://doi.org/10.1016/B978-0-12-4046993.00043-3.

(48) Paz-Yépez, C.; Peinado, I.; Heredia, A.; Andrés, A. Influence of Particle Size and Intestinal Conditions on in Vitro Lipid and Protein Digestibility of Walnuts and Peanuts. Food Research International 2019, 119 ,

951-959.

https://doi.org/10.1016/j.foodres.2018.11.014.

(49) Engelen, M. P. K. J.; Rutten, E. P. A.; De Castro, C. L. N.; Wouters, E. F. M.; Schols, A. M. W. J.; Deutz, N. E. P. Supplementation of Soy Protein with Branched-Chain Amino Acids Alters Protein Metabolism in Healthy Elderly and Even More in Patients with Chronic Obstructive Pulmonary Disease. American Journal of Clinical 
Nutrition 2007, $85 \quad$ (2), 431-439. https://doi.org/10.1093/ajcn/85.2.431.

(50) Bonafaccia, G.; Galli, V.; Francisci, R.; Mair, V.; Skrabanja, V.; Kreft, I. Characteristics of Spelt Wheat Products and Nutritional Value of Spelt Wheat-Based Bread. Food Chemistry 2000, 68 (4), 437-441. https://doi.org/10.1016/S0308-8146(99)00215-0.

(51) Chung, H. J.; Liu, Q.; Hoover, R.; Warkentin, T. D.; Vandenberg, B. In Vitro Starch Digestibility, Expected Glycemic Index, and Thermal and Pasting Properties of Flours from Pea, Lentil and Chickpea Cultivars. Food Chemistry 2008, 111 (2), 316-321. https://doi.org/10.1016/j.foodchem.2008.03.062.

(52) Goñi, I.; Garcia-Alonso, A.; Saura-Calixto, F. A Starch Hydrolysis Procedure to Estimate Glycemic Index. Nutrition Research 1997, 17 (3), 427-437. https://doi.org/10.1016/S0271-5317(97)00010-9.

(53) Hoover, R.; Zhou, Y. In Vitro and in Vivo Hydrolysis of Legume Starches by $\alpha$-Amylase and Resistant Starch Formation in Legumes A Review. Carbohydrate Polymers. December 1, 2003, pp 401-417. https://doi.org/10.1016/S0144-8617(03)00180-2.

(54) Rehman, Z. U.; Shah, W. H. Thermal Heat Processing Effects on Antinutrients, Protein and Starch Digestibility of Food Legumes. Food Chemistry 2005, 91

327-331. https://doi.org/10.1016/j.foodchem.2004.06.019.

(55) Ruales, J.; Nair, B. M. Effect of Processing on in Vitro Digestibility of Protein and Starch in Quinoa Seeds. International Journal of Food Science \& Technology 1994, 29 (4), 449-456. https://doi.org/10.1111/j.1365-2621.1994.tb02086.x.

(56) Wang, T. L.; Domoney, C.; Hedley, C. L.; Casey, R.; Grusak, M. A. Can We Improve the Nutritional Quality of Legume Seeds? Plant Physiology. American Society of Plant Biologists March 1, 2003, pp 886-891. https://doi.org/10.1104/pp.102.017665.

(57) Bao, W.; Li, Q.; Wu, Y.; Ouyang, J. Insights into the Crystallinity and 
in Vitro Digestibility of Chestnut Starch during Thermal Processing. Food Chemistry 2018, 269, 244-251. https://doi.org/10.1016/j.foodchem.2018.06.128.

(58) Liu, Q.; Donner, E.; Yin, Y.; Huang, R. L.; Fan, M. Z. The Physicochemical Properties and in Vitro Digestibility of Selected Cereals, Tubers and Legumes Grown in China. Food Chemistry 2006, 99 (3), 470-477. https://doi.org/10.1016/j.foodchem.2005.08.008.

(59) Yadav, B. S.; Sharma, A.; Yadav, R. B. Studies on Effect of Multiple Heating/Cooling Cycles on the Resistant Starch Formation in Cereals, Legumes and Tubers. International Journal of Food Sciences and $\begin{array}{llll}\text { Nutrition } & 2009, & 60 & \text { (SUPPL.4), }\end{array}$ https://doi.org/10.1080/09637480902970975.

(60) Woda, A.; Foster, K.; Mishellany, A.; Peyron, M. A. Adaptation of Healthy Mastication to Factors Pertaining to the Individual or to the Food. Physiology and Behavior 2006, 89 (1), 28-35. https://doi.org/10.1016/j.physbeh.2006.02.013.

(61) Chen, X.; He, X. W.; Zhang, B.; Fu, X.; Jane, J. lin; Huang, Q. Effects of Adding Corn Oil and Soy Protein to Corn Starch on the Physicochemical and Digestive Properties of the Starch. International Journal of Biological Macromolecules 2017, 104, 481-486. https://doi.org/10.1016/j.ijbiomac.2017.06.024.

(62) Kristensen, M.; Jensen, M. G. Dietary Fibres in the Regulation of Appetite and Food Intake. Importance of Viscosity. Appetite 2011, 56 (1), 65-70. https://doi.org/10.1016/j.appet.2010.11.147.

(63) Wolter, A.; Hager, A. S.; Zannini, E.; Arendt, E. K. In Vitro Starch Digestibility and Predicted Glycaemic Indexes of Buckwheat, Oat, Quinoa, Sorghum, Teff and Commercial Gluten-Free Bread. Journal of Cereal Science 2013, 58 (3), 431-436. https://doi.org/10.1016/j.jcs.2013.09.003.

(64) Guéguen, L.; Pointillart, A. The Bioavailability of Dietary Calcium. Journal of the American College of Nutrition 2000, 19 (sup2), 119S- 
136S. https://doi.org/10.1080/07315724.2000.10718083.

(65) Schlemmer, U.; Frølich, W.; Prieto, R. M.; Grases, F. Phytate in Foods and Significance for Humans: Food Sources, Intake, Processing, Bioavailability, Protective Role and Analysis. Molecular Nutrition and Food Research. Wiley-VCH Verlag September 2009, pp S330-S375. https://doi.org/10.1002/mnfr.200900099.

(66) McCabe, L. D.; Martin, B. R.; McCabe, G. P.; Johnston, C. C.; Weaver, C. M.; Peacock, M. Dairy Intakes Affect Bone Density in the Elderly. The American journal of clinical nutrition 2004, 80 (4), 1066-1074. https://doi.org/10.1093/ajcn/80.4.1066. 
6 CONCLUDING REMARKS 


\section{Concluding remarks}

The population aged 65 or over can present deficiencies in the digestion and absorption of macro and micronutrients - mainly proteins, calcium and liposoluble vitamins - that frequently lead to sarcopenia and other related health issues.

The main results obtained in this doctoral thesis allow concluding that in elderly subjects presenting oral/dental altered conditions, the consumption of lean fish, egg (regardless the cooking method), poultry and pork meats as well as legumes are more advisable to ensure protein digestibility than other foods. By their hand, if gastric conditions are suboptimal (elevated pH and reduced pepsin concentration), hydrolysis of dairy proteins would be diminished. Besides, results stated that pancreatic and biliary insufficiencies together with slower transit time are the main responsible of maldigestion in elders. Under these alterations, the consumption of lean fish, hard-boiled and poached eggs, cheeses, poultry and beef meats, as well as all the studied legumes should be chosen in elders' diet. From a qualitative point of view, it is important to point out that altered gastrointestinal conditions, and specifically those given at intestinal stage, seem to increase the essential/non-essential amino acids ratio. This fact can be considered positive because of a higher amount of essential amino acids release, including those involved in the synthesis of muscle mass, contribute against sarcopenia in elders. Lastly, end-digestion products of proteolysis, mainly bioactive peptides and free amino acids, from turkey meat provides the greatest antihypertensive activity; while those from pork meat exert the highest antioxidant activity under altered gastrointestinal conditions of elders.

Regarding to other relevant nutrients such as lipids, carbohydrates, liposoluble vitamins (A and D3) and calcium, oral, gastric and/or intestinal disorders differently affect these nutrients. Lipolysis extent is not limited by u elders' gastrointestinal conditions. Glycolysis was reduced under suboptimal conditions, thus positively contributing to the glycemic index in 
legumes and pseudocereals. Concretely, digested lentils, chickpea and spelt under altered conditions resulted in a more hypoglycemic food than under optimal standard conditions. In addition, the consumption of aged cheese would be more recommendable that other dairy products because its low lactose content together with the excellent protein and lipid digestibility, even under altered digestive conditions.

Considering the net bioaccessible fraction of calcium under elders' digestive conditions, sardines would be considered a good option when alterations are given in the whole digestive system. However, if gastric conditions are suboptimal, fresh cheese, chickpeas and soybeans will also contribute positively to achieve the daily recommendation of calcium in its released form. Likewise, people suffering only of intestinal disorders would benefit from prioritizing the consumption of cheese and some grains (chickpeas and soybeans). Regarding to the effect of altered digestive conditions on liposoluble vitamins, results show a progressive reduction in their bioaccessibility as long as digestive alterations appeared from oral to intestinal stage. Even though and considering the net supply of those vitamins in their bioaccessible form, the best sources for elders would be salmon, sea bass, fresh and aged cheeses, and eggs. 
7 FUTURE PERSPECTIVES 


\section{Future perspectives}

So far in this thesis, the results have already contributed to generate knowledge about how the most frequent gastrointestinal alterations in senior population impact on proteolysis, glycolysis and lipolysis extents as well as fat-soluble vitamins, calcium and bioactive compounds bioaccessibilities of different food groups. Although recommendations based on scientific evidence established the foods that could help to fight against malnutrition and sarcopenia, more research is needed. In vitro digestion model that allowed to simulate in an accumulative form the alterations in the mouth, stomach and intestine implied in the luminal digestion in elders is a powerful tool to continue exploring other foods and their combinations. Moreover, dynamic in vitro systems can be also used to study the foods' digestion fate with more realistic and closer conditions to the physiological. Additionally, the colonic fermentation, not studied in the frame of this doctoral thesis, is a topic of great interest and the most recommended foods of this study should be studied from this perspective. Colonic studies allow to understand the fate digestion of non-digestible carbohydrates or non-absorbed proteins, as well as the impact of food composition on the metabolites produced by the microbiota. Besides, information about the effect of type of diet or food intake on colonic microbiota populations can be generated with the adequate systems. In fact, a new infrastructure acquired by the research group (a Simulator of Human Intestinal Microbial Ecosystem (SHIME $\left.{ }^{\circledR}\right)$ ) has been recently installed and set up, representing a great opportunity to expand the objectives of this doctoral thesis.

Finally, the ultimate goal of these type of studies would be the development of new foods with specific characteristics to enhance the health status of aged people. Foods aimed at the senior population are an important market niche for the industry, as long as the developments are made under a comprehensive approach that assesses not only the sensory quality of the 
new foods but also considering their health benefits. Plant-protein-rich foods such as legumes and some cereals/pseudocereals can be used to generate new foods with good eat quality, affordable, sustainable and with high digestible rates. These products are excellent options to achieve the demand of food products easy to chew and swallow attending to the physiological, nutritional and specific needs of the elderly. Specific characteristics of these foods can be improved by exploring new processing strategies such as solid-state fermentation using several microorganisms. Solid-state fermentation has been reported to increase nutrients digestibility and decrease the adverse effects of antinutrients.

Finally, in spite of the demonstrated utility of in vitro tools for screening purposes and for food development, a final step must be considered. Validating the results in vivo will be always required allowing even to take into account individual factors and to move forward a personalized nutrition strategies. 